\title{
Blessed: A History of the American Prosperity Gospel
}

\author{
by \\ Catherine Bowler \\ Graduate Program in Religion \\ Duke University
}

Date:

Approved:

Grant Wacker, Supervisor

Thomas Tweed

Julie Byrne

Mark Chaves

\section{Glenn Hinson}

Dissertation submitted in partial fulfillment of the requirements for the degree of Doctor of Philosophy in the Graduate Program in Religion in the Graduate School of Duke University 


\title{
$\underline{\text { ABSTRACT }}$ \\ Blessed: A History of the American Prosperity Gospel \\ by
}

\author{
Catherine Bowler \\ Graduate Program in Religion \\ Duke University
}

Date:

Approved:

Grant Wacker, Supervisor

Thomas Tweed

Julie Byrne

Mark Chaves

Glenn Hinson

An abstract of a dissertation submitted in partial fulfillment of the requirements for the degree of Doctor of Philosophy in the

Graduate Program in Religion in the Graduate School of Duke University

2010 
Copyright by Catherine Bowler 2010 


\section{Abstract}

This dissertation introduces readers to the major figures and features of the twentieth-century American prosperity gospel. It argues that these diverse expressions of Christian faith-fuelled abundance can be understood as a movement, for they stem from a cohesive set of shared understandings. First, the movement centered on Faith. It conceived of faith as an "activator," a power given to believers that bound and loosed spiritual forces and turned the spoken word into reality. Second and third respectively, the movement depicted faith as palpably demonstrated in wealth and health. It could be measured in both in the wallet—one's personal wealth—and in the body-one's personal health-making material reality the measure of the success of immaterial faith. Last, the movement expected faith to be marked by victory. Believers trusted that culture held no political, social, or economic impediment to faith, and no circumstance could stop believers from living in total victory here on earth. Though its origins lay in the late nineteenth century, the prosperity gospel took root in the Pentecostal revivals of the post-World War II years. It reached maturity by the late 1970 s as a robust pandenominational movement, garnering a national platform and a robust network of churches, ministries, publications, and media outlets. Using the tools of ethnography and cultural history, this dissertation argues that faith, wealth, health, and victory served as the hallmarks of this American phenomenon. 


\section{Dedication}

To my parents, for their loving home,

And to Toban, for bringing it with us

On all life's journeys. 


\section{Contents}

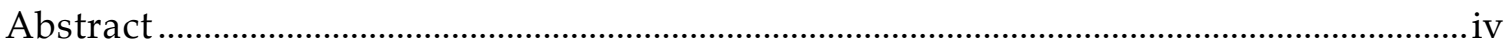

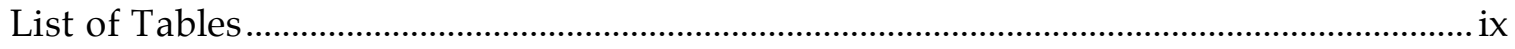

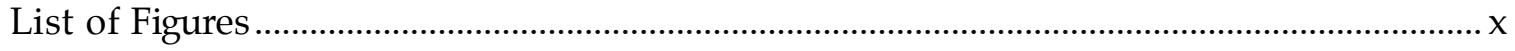

Acknowledgements ...........................................................................................................

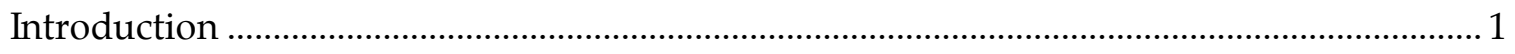

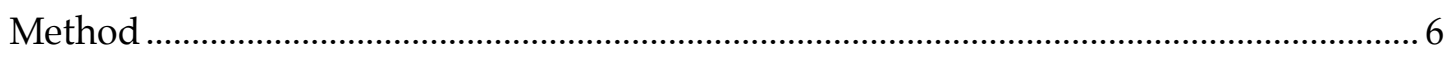

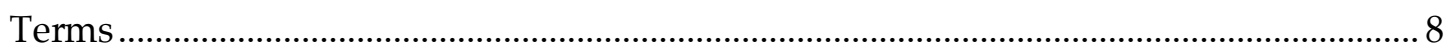

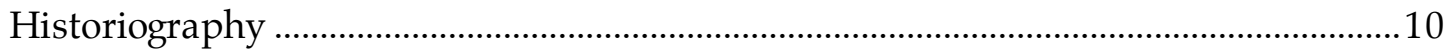

An Introduction to the Faith Movement ..............................................................................13

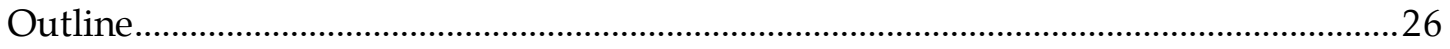

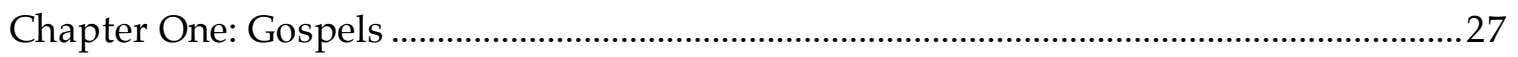

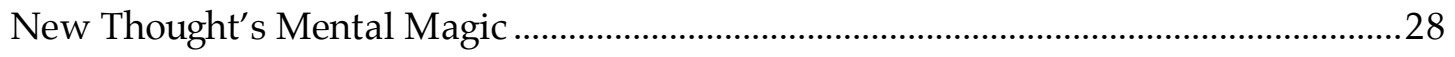

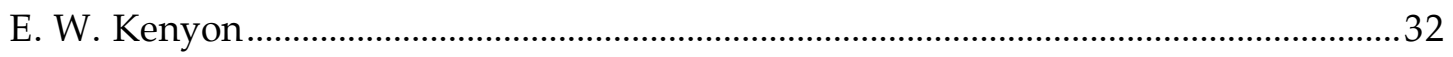

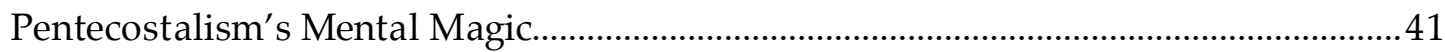

Health, Wealth, and the Rise of Black Metaphysical Religion ........................................46

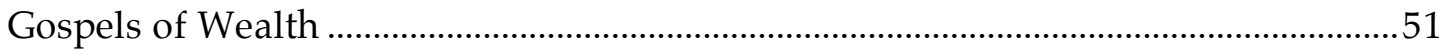

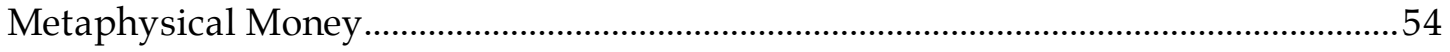

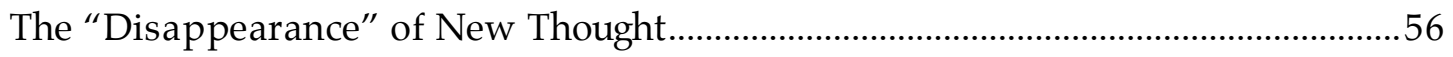

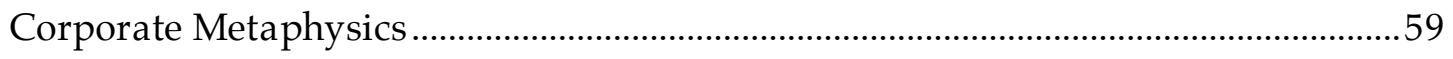

Twice Blessed: The Gospel of Health and Wealth ............................................................ 61

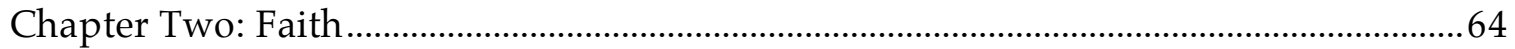

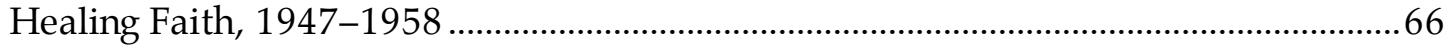

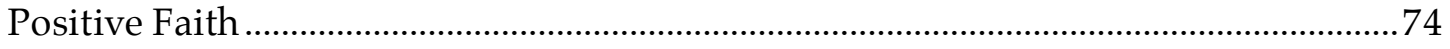




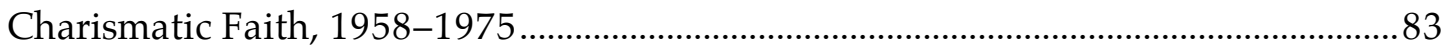

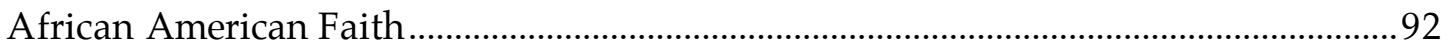

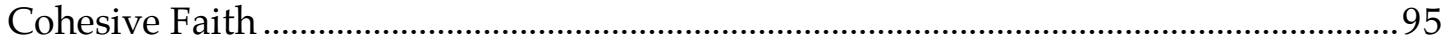

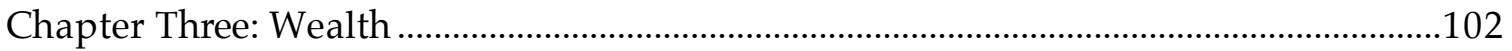

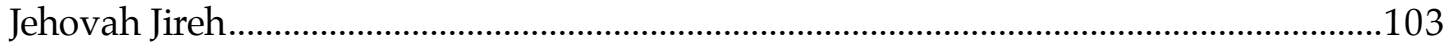

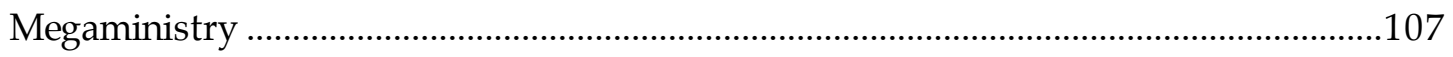

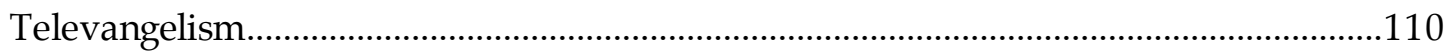

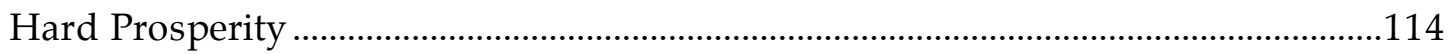

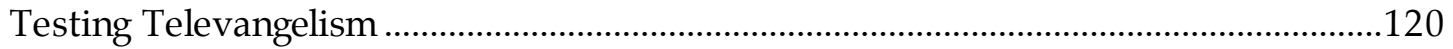

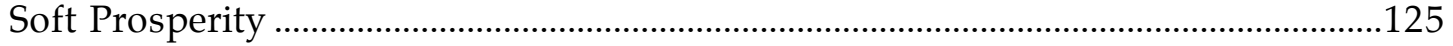

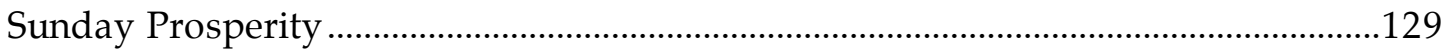

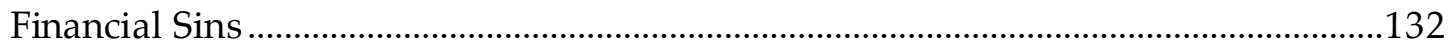

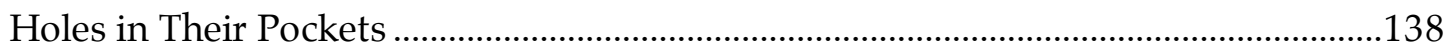

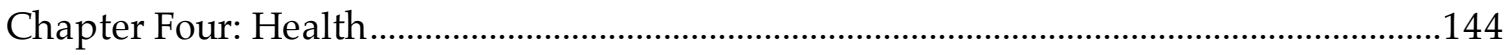

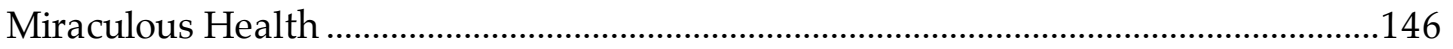

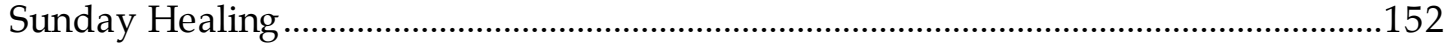

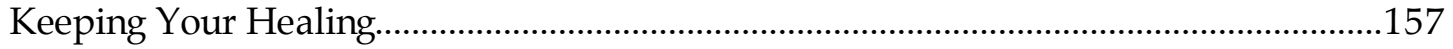

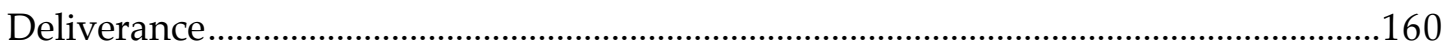

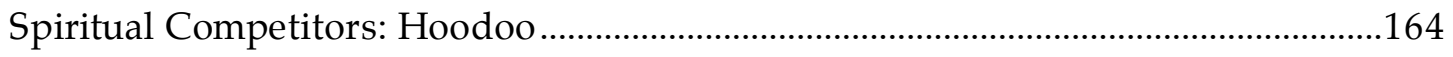

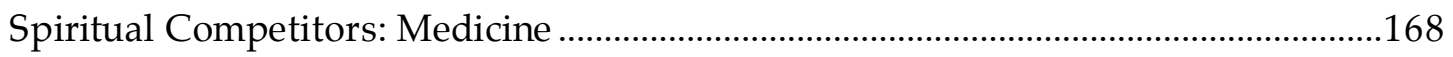

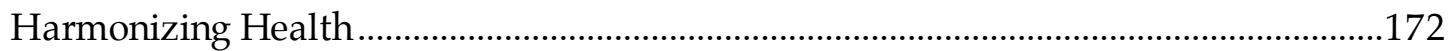

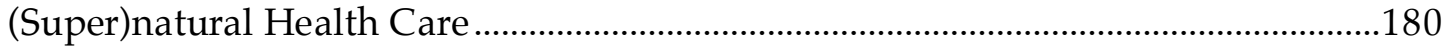

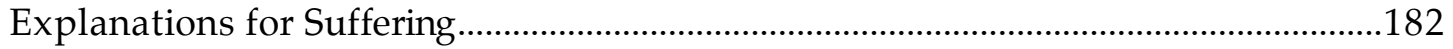

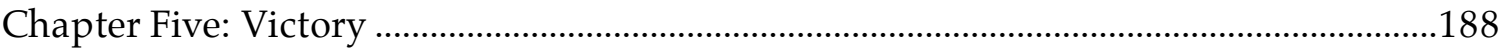

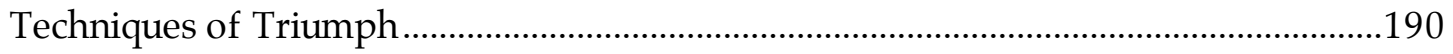




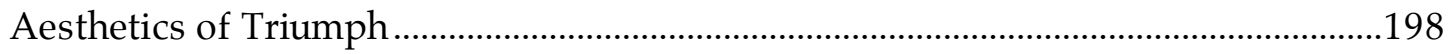

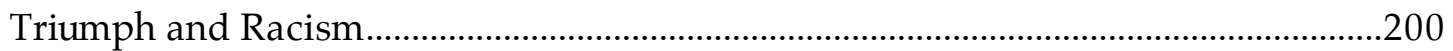

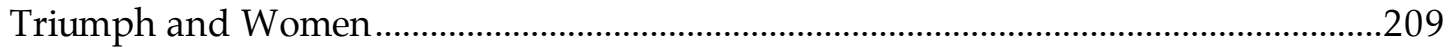

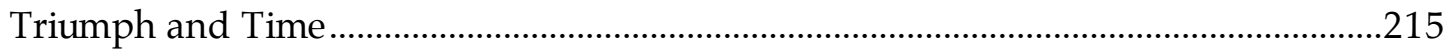

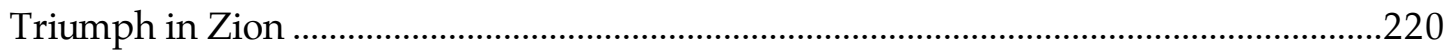

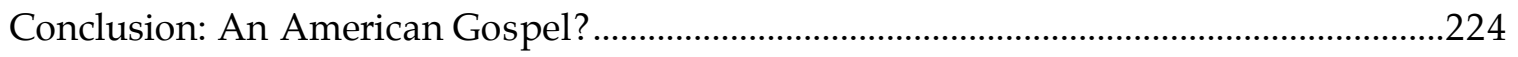

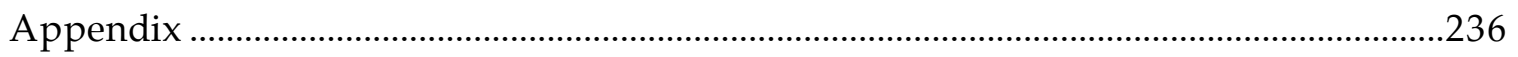

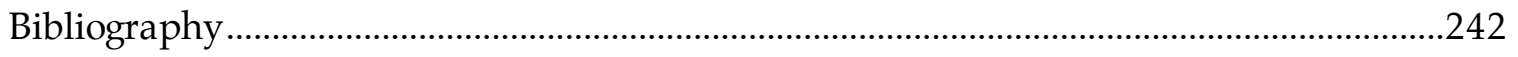

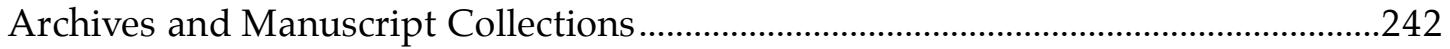

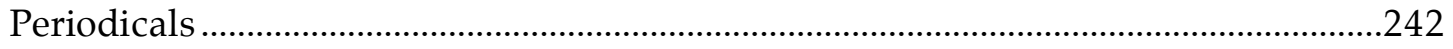

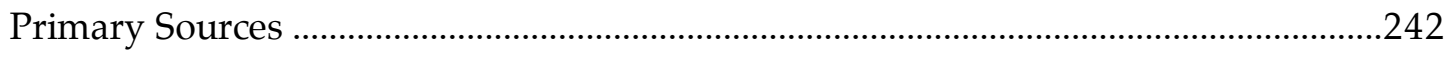

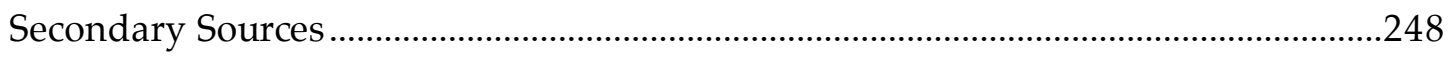

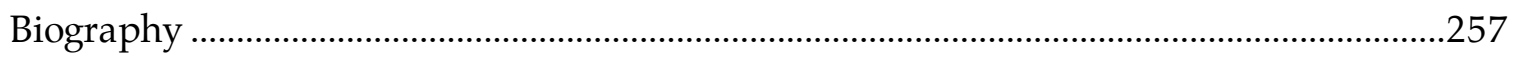




\section{List of Tables}

Table 1: Prosperity Megachurch Distribution by Size Compared to Megachurches

Nationally.

Table 2: Percentage of Pentecostal Prosperity Megachurches Among All Faith

Megachurches. 


\section{List of Figures}

Figure 1: Prosperity Megachurches by Size. The average congregation contained 6,834 members

Figure 3: Prosperity Megachurch Locations in Mainland United States. The highest number of prosperity megachurches resided in Texas (11), followed by California (9), and Georgia (8).

Figure 4: Regional Distribution of Prosperity Megachurches Compared with Megachurches Nationally. Prosperity megachurches are concentrated in the West, South, and Southeast

Figure 5: Prosperity Megachurches by Denomination. Nondenominational congregations dominated. 


\section{Acknowledgements}

This project benefited from a great many people. First, I must acknowledge the support of my family. I can never express the full measure of gratitude I owe them for making this dissertation possible. My husband, Toban, offered his support with characteristic patience and sweetness. I imagine perfection looks a lot like a husband who (without caring what I chose for my profession) happily chats about "our dissertation" while making dinner. My mother and father read every word and gave unflagging encouragement. They lavished me with hundreds of hours of loving care without ever making me promise to give them grandchildren. My older sister Amy cheerfully prepared my bibliography and younger sister Maria took beautiful photos for publication. I could not have made it over the finish line without them.

I must acknowledge the incredible support of my dissertation committee. My graduate advisor, Grant Wacker, bravely took me as a student with no background in American religious history and encouraged me to tackle big ideas. Grant's incredible support and hatred for passive verbs will remain with me always. Tom Tweed went above and beyond to give me the tools to think critically and to encourage me to be myself. Thank you for letting "many flowers bloom." Glenn Hinson, Mark Chaves, and Julie Byrne brought rigor and kindness to every encounter.

A wonderful community of scholars helped me along. Many thanks to my fellow Dukies, Mandy McMichael, Chad Eggleston, Seth Dowland, Elesha Coffman, Sarah Johnson, Heather Vacek, Brendan Pietsch, David King, Joshua Vis, Mary Sanden, Katherine Hande Smith, and Angela Tarango for being my conservation partners over the years. Scott Billingsley and John Stackhouse gave me valuable assistance. Heather Moffitt saved me from more errors than I can count. John David Roebuck of the Dixon 
Pentecostal Research Center, Darrin Rodgers of the Flower Pentecostal Heritage Center, and Rick Hiemstra of the Centre of Research on Canadian Evangelicalism generously helped me along the way.

Finally, I owe a debt of appreciation to the members of Durham's Victorious Life Center for sharing their lives with me. "Gratitude bestows reverence," observed John Milton, "allowing us to encounter everyday epiphanies, those transcendent moments of awe that change forever how we experience life and the world." This work has been enriched by their everyday epiphanies. 


\section{Introduction}

The "Victorious Faith Center" sign blinked red, sandwiched between a nail salon and a payday loan office in a Durham, North Carolina, mini-mall. I chose this neighborhood church for my ethnography, certain that the church's name signaled its place in the wider Faith movement. After all, the Faith movement offered victorious Faith, the power to imbue believers with spiritual, physical, and financial mastery over their lives. The Pastor and First Lady agreed to meet to discuss my project, and I was eager to discover their formal links with larger ministry networks. ${ }^{1}$ As I launched into a description of my study, I felt the emotional temperature drop. No, the Pastor stated firmly, his teachings had no historical precedent. They were born from revelation. "What about the church's name?" I asked. It had come to him in a dream. I began to see that this line of questioning violated his sense of integrity as a prophet. I started to rummage for new possibilities for my research, when a magazine on the coffee table caught my eye. It was the Word of Faith, the official publication of the flagship Word of Faith institution, Rhema Bible Training Center. The sight of the magazine prompted a different line of questioning. The hidden structures of the Faith movement emerged. Pastor Walton spent several years learning from famed prosperity preacher Robert Tilton at his Bible school in Texas, and had sustained the momentum of his ministry with Faith publications and intermittent trips to witness divine healer Benny Hinn's crusades. The church "sowed into" the ministries of celebrities like Creflo Dollar, Kenneth Hagin, and Joel Osteen. While Pastor Walton believed his insights and preaching bubbled up from the wellsprings of Scripture and personal revelation, in song, sermon, and giving, Sunday

\footnotetext{
1 "First Lady" refers to the traditional title given to the male pastor's wife among African American congregations.
} 
mornings at the Victorious Faith Center closely resembled thousands of similar churches dotting the American religious landscape.

The seeming independence of churches like the Victorious Faith Center puzzled pastors, scholars, and media pundits alike. Few knew how to measure the breadth of the prosperity movement, or even how to lay the tape. The prosperity gospel was not bounded strictly by region, as Faith celebrities hailed from Seattle to New York, Houston to Chicago. Denominational markers did not offer many clues, since most churches claimed nondenominational status. Congregational size also proved inconclusive. While famous Faith congregations like Lakewood Church or The Potter's House crowded the list of American megachurches, countless small congregations proclaimed an equally fervent prosperity gospel. Likewise, these congregational estimates could not account for the millions of Americans who participated by watching their favorite Faith televangelists, reading their publications, or attending their conferences. Further, common sense often sent researchers in the wrong direction. The prosperity message favored theological conservatism, and yet, organizationally it was unlike other conservative movements that tended to produce mandates and institutions with iron-clad purpose. The Faith gospel lacked the semblance of this well-oiled institutional machinery, leading many observers to conclude that Faith celebrities operated as theological and institutional independents, rising, persisting, and falling haphazardly. They appeared to be solo evangelists—-fireflies that flickered on and off, here and there, each burning brightly and then fading without consistency or connection.

Diverse expressions of this vibrant and energetic faith abounded on the American religious terrain. T. D. Jakes, dubbed by Time magazine as one of America's most influential new religious leaders, built a financial empire with his 17,000-member congregation, media empire, and more than two-dozen books on emotional healing. In Houston, Joel Osteen, known as the "smiling preacher," inspired his 43,500-member 
congregation through humorous and lightly theological sermons salted with insights from his self-help bestseller, Become a Better You. Creflo Dollar, pastor of Atlanta's 15,000member World Overcomers Church, traded Osteen's smiles for fatherly admonitions, urging his mostly black church members to increase their wealth by increasing their faith. Frederick Price, the Los Angeles pastor of Crenshaw Christian Center, lambasted traditional Christianity as a "slave religion" and implored his 5,000-member congregation to use prosperity theology to overcome Christian barriers to black upward mobility. Joyce Meyer eschewed a conventional church ministry altogether, and toured America's largest cities with a message of abundance and hope heard largely by audiences of white middle-aged women. These independent ministers, taken together, operated as a major force in American religion, generating millions of followers and financial donations.

This dissertation introduces readers to the major figures and features of the twentieth-century American prosperity gospel. It argues that these diverse expressions of Christian faith-fuelled abundance can be understood as a movement, for they stemmed from a cohesive set of shared understandings. First, the movement centered on Faith. It conceived of faith as an "activator," a power given to believers that bound and loosed spiritual forces and turned the spoken word into reality. Second and third respectively, the movement depicted faith as palpably demonstrated in wealth and health. It could be measured in both in the wallet-one's personal wealth-and in the body—one's personal health—making material reality the measure of the success of immaterial faith. Last, the movement expected faith to be marked by victory. Believers trusted that culture held no political, social, or economic impediment to faith, and no circumstance could stop believers from living in total victory here on earth. Though its origins lay in the late nineteenth century, the prosperity gospel took root mainly in the Pentecostal revivals of the post-World War II years. It reached maturity by the late 
1970 s as a robust pan-denominational movement, garnering a national platform and a robust network of churches, ministries, publications, and media outlets. ${ }^{2}$ Taken whole, as the following chapters argue, faith, wealth, health, and victory served as the hallmarks of this American phenomenon.

Millions of America fell in love with the prosperity gospel and its new kind of preacher. Charming though not effusive, polished but not slick, these favored few could as easily have appeared on Larry King Live as behind their megachurch Sunday pulpits. Podcasts, Internet streaming, and daily television programming carried their sermons to millions. They cultivated their fame with personal appearances in sold-out arenas. The megachurch ministerial elite dominated not only religious media networks, like Pat Robertson's Christian Broadcasting Network or the Crouches' Trinity Broadcasting Network, but secular outlets as well, becoming mainstays on stations like Black Entertainment Television. Some climbed the charts of the New York Times bestsellers list, and all found their titles lining the Religion/Inspiration aisles from Walmart to Barnes \& Noble. The Senate buzzed about these celebrities' high profit margins, while bloggers and

\footnotetext{
${ }^{2}$ Why use the image of network? Theorists of religion would happily supply other analogies, each with distinct advantages. Spatial metaphors, charting maps, geographies, or landscapes, emphasize the location of religion, adding texture to arguments about context and embodiment. Fluid metaphors, following flows, currents, or streams, call attention to the dynamism and mobility of religion. Religion as "network" focuses on connectivity and association, the pathways forged over time and space. I have chosen the concept of network for several reasons. First, it bears descriptive advantages. As this work examines several dozen major leaders and institutions, the term network allows me to describe not only scope but also the density of interconnection, weighting religious significance based on who or what is most linked to others. In doing so, I borrow lightly from network theory in attempting to adjudicate significance by interconnection. Second, the term network emphasizes nodes, power, and authority concentrated in particular institutions and personalities. I envision the Faith movement as propelled primarily by a cluster of leaders and institutions whose activities bear weight. Yet network, as a metaphor, has obvious limitations. It may lull readers into the false sense that religion is static, that the network is, in fact, an iron grid. As Manuel Vásquez has argued, networks must not be mistaken for "closed, linear systems that automatically integrate constituent parts in a harmonious whole." It should rather be imagined more as a circuit board, a template that conducts movement and energy. M. A. Vasquez, "Studying Religion in Motion: A Networks Approach," Method and Theory in the Study of Religion, 20 (2008), 151-184.
} 
media pundits debated each ministerial expenditure. ${ }^{3}$ Loved or hated, they were never forgotten. At almost any moment, day or night, the American public could tune in to see these familiar faces and a consistent message: God desires to bless you.

By 2000, a dozen or so Faith teachers had attained American celebrity and become powerful nodes in the prosperity movement. To their congregations, they acted as pastors, prophets, and visionaries. They attracted spiritual tourists and members alike to their church complexes, thickets of offices, television production studies, classrooms and sanctuaries. They put on hard hats and cut ribbons for their latest building projects, and then quickly set a new goal in the church's sights. To the secular media, they represented the Christianity of the American marketplace. With microphones pinned to their lapels, they preached upbeat messages of God's goodness and human potential. They knew the questions would naturally turn to their personal wealth, and defended their personal jets and real estate assets with examples of their altruistic motives. And to popular religious audiences, they served as America's counselors, self-help advisors as trusted as professional therapists. In 2007 and 2008, T. D. Jakes appeared easily alongside Dr. Phil on the psychologist's hit television show, two relationship experts with cures for the country's ills. In those roles, Faith celebrities became leaders of a popular religious force. Given their fame, importance, and influence, examining the crucial network nodes of these Faith celebrities is perhaps the best means for creating a broad view of the wider Faith network. These teachers, and others like them, constituted the national leadership of the Prosperity movement, commanding some of the nation's largest spiritual audiences through pulpits and television cameras.

\footnotetext{
${ }^{3}$ In 2007, Sen. Chuck Grassley of the Senate Finance Committee launched an investigation of six famous Prosperity teachers: Joyce Meyer, Benny Hinn, Creflo Dollar, Paula White, Eddie Long, and Kenneth and Gloria Copeland. In 2009, according to Grassley, Joyce Meyer and Benny Hinn had been cleared. Eddie Long and the Copeland submitted "incomplete responses." Creflo Dollar declined to comply with the investigation. See United States Committee on Finance Memorandum, March 12, 2009, http: / / finance.senate.gov/press / Gpress / 2009/prg031209a.pdf (accessed Feb 2, 2010).
} 
In 2010, the Faith movement claimed millions of American followers, though estimates were hard to pin down. A recent Time poll found that 17 percent of Christians surveyed identified themselves as part of the movement, while 31 percent believed that God increases the riches of those who give. A full two thirds agreed that God wants people to prosper. ${ }^{4}$ A Pew survey reported that 43 percent of all Christian respondents agreed that the faithful receive health and wealth. A 2008 Pew study found that threein-four Latino believers-Catholic, mainline, and evangelical-agreed with the statement: "God will grant financial success and good health to all believers who have enough faith." ${ }^{5}$ Many Americans had made this gospel their own.

\section{Method}

I first encountered the prosperity gospel in my hometown of Winnipeg, Manitoba, the site of Springs Church, the largest church in Canada and an expansive church complex jutting out from the prairie snow scape. Springs Church boasted a congregation of 10,000-uncommonly large for the Canadian religious scene-and a message of spiritual and financial abundance. ${ }^{6}$ It was a historical puzzle. People seeking God's money normally are poor, scholars say, but Springs Church gathered an affluent congregation. Prevailing wisdom also suggests that the congregation will draw from those steeped in Pentecostal or Holiness movements that have seen this message. Instead, Springs Church drew largely from a Mennonite heritage, a people known for being deeply unmoved by the Toronto Blessing and other religious revivals, and a

\footnotetext{
${ }^{4}$ David Van Biema and Jeff Chu, “Does God Want You To Be Rich?” Time, September 6, 2006. http: / / www.time.com/time/magazine/article/0,9171,1533448,00.html (accessed January 7, 2010). In 2006, The Yearbook of American and Canadian Churches estimated that Word-Faith members numbered from $4,600,000$ to $4,800,000$. At less than two percent of the population, this total likely only included those churches affiliated with a Word of Faith denomination. See Eileen Lindner, Yearbook of American and Canadian Churches (New York: NCC Communication Department, 2006), 365-377.

5 "Changing Faiths: Latinos and the Transformation of American Religion," (2006 Hispanic Religion Survey) http: / / pewforum.org/newassets / surveys/hispanic/ hispanics-religion-07-final-mar08.pdf (accessed January 7, 2010).

${ }^{6}$ Springs Church. http:/ / www.springschurch.com (accessed February 2, 2010).
} 
tradition not known for the ostentatious pursuit of wealth. I began to suspect that if prosperity theology could thrive among the stolid citizens of Winnipeg, it must exist in all corners of North America. And so I started to seek out prosperity churches as I traveled around the United States for school and pleasure, attending as many different congregations as my time (and husband) could tolerate.

My ethnographic work took three main forms. First, as mentioned, I have supplemented the historical narrative with trips to American Faith congregations and conferences, including those of T. D. Jakes, Joel Osteen, Paula White, Joyce Meyer, Kenneth and Lynnette Hagin, and many others. Second, the generous assistance of a Duke University travel grant allowed me to tour Israel with Benny Hinn's 2008 Holy Land Tour. For two weeks, I joined 900 participants on their spiritual pilgrimage better to understand the expectations of those who seek out Faith leaders at great cost. I have kept the identities of my fellow travelers anonymous, for though many generously shared their time and stories, it could hardly be said that they chose to be assigned to a bus with an eager researcher. Third, I spent eighteen months learning from the members of the Victorious Faith Center (VFC), an eighty-member African American prosperity church in Durham, North Carolina. In January 2007, I began my ethnography at this church as a graduate student in Professor Glenn Hinson's class “The Art of Ethnography" at the University of North Carolina, Chapel Hill. I continued to attend as a participantobserver and researcher until the summer of 2008. After eighteen months of regular Sunday (and frequent Wednesday evening) attendance, I completed a dozen interviews and joined in many more informal conversations over lunch, coffee, and e-mail exchanges. Initially, I adopted a collaborative ethnographic model, attempting to involve 
consultants in a shared interviewing, writing, and editing process. ${ }^{7}$ I soon realized that for many participants, this method might be prohibitive and possibly harmful. Their theology commanded positive speech, and some consultants saw being interviewed as tantamount to "negative confession," the proclamation of disease or misfortune that causes these circumstances to be actualized. My moral responsibility to them led me to switch to a less interactive model, but one that still values the honesty, vulnerability, and accessibility that marks collaborative ethnography. I solicited feedback from those interviewees for whom negative confession would not be an issue, either because what they said was positive or because they did not rigorously monitor their speech practices. I have done my best to conceal the identities of the members of VFC and the church itself out of respect for the kindness and consideration they extended to me.

\section{Terms}

I use the terms Faith movement, prosperity movement, prosperity theology, and prosperity gospel interchangeably. I follow E. W. Kenyon, the theological architect of the movement, in capitalizing "Faith." In doing so, I hope to draw attention to the animating qualities that separate it from its traditional definition as "hope" or perhaps, "trust." I only use the term "Word of Faith" to describe individuals and churches closely associated with the ministry of Kenneth Hagin Sr. and his Rhema Bible Training Center. His monthly publication The Word of Faith cemented the association between the two. All others fall under the wide umbrella of "Faith" or "prosperity."

There are two obvious disadvantages to using the term prosperity. First, for believers, to call their message anything other than "the Gospel" marked it as outside the

\footnotetext{
${ }^{7}$ Luke Lassiter, The Chicago Guide to Collaborative Ethnography (Chicago: University of Chicago Press, 2005), especially chapters 5 and 6: "Ethics and Moral Responsibility," and "Ethnographic Honesty." See also American Anthropological Association. Code of Ethics of the American Anthropological Association (1998) http: / / w ww.aaanet.org/ committees / ethics / ethcode.htm (accessed February 2, 2010); Glenn Hinson, "Stepping Around Experience and the Supernatural," Fire in My Bones: Transcendence and the Holy Spirit in African American Gospel (Philadelphia: University of Pennsylvania Press, 2000), 327-334.
} 
boundaries of Christianity. In interviews with participants, the first ten minutes inevitably circled around why I might be calling it "prosperity" or "the Faith movement" at all when the message sprang from the pages of the Bible itself. While the act of labeling cannot be avoided, participants rightly bristled at the implication of theological innovation. Second, related to the first, the label "prosperity" conjures up a primarily economic motivation. It follows the thesis set forth by Irvin G. Wyllie in The Self-Made Man in America that where religion and self-improvement meet, riches is at the heart of the effort. ${ }^{8}$ I continue to use the term, however imperfect, as insiders agreed that (rightly defined) prosperity summarized both the focus and the distinctiveness of their message to the world.

Given its limitations, I feel the need to add a few cautionary words. First, it should be remembered that, at a fundamental level, American desires for the "good life" are basic and ordinary. All people long for the necessities that sustain life and rejoice when those goods overflow. In an academic profession dominated by the upper-middle class, it is important to remember that prosperity must not be read pejoratively as indulgence or fetish, but as a humdrum part of everyday living. Second, religion and money have never stood more than an arm's-length apart. Economic status divides us all into strata, groupings of taste, habit, and lifestyle. It largely dictates where we live, with whom we associate, and what horizons we imagine for ourselves. Prosperity (and the fluctuating criteria by which to measure how much is enough) is both the substance of ethical debate and a deeply rooted means by which we adjudicate our place in the world. Religious beliefs, practices, and institutions naturally assign value to these economic accidents or consequences, making prosperity a crucial arena of spiritual meaning making.

\footnotetext{
${ }^{8}$ Irvin Wyllie, The Self-Made Man in America: The Myth of Rags to Riches (New Brunswick, NJ: Rutgers University Press, 1954).
} 
Third, this dissertation examines only one of America's prosperity gospels. In American religious history, countless clergy and laypeople have speculated about the relationship between God's favor and hunger or plenty. ${ }^{9}$ Recipes for success have contained a changing list of ingredients, and American religion could hardly exhaust its possibilities. It cannot serve as an organizing theme for the whole of American religious history because it rarely evoked a common response. American believers, at times, expressed ambivalence about the importance of wealth, or declared it incompatible with virtue. Many Christians, peering through the eye of a needle, declared prosperity an undesirable end. ${ }^{10}$

Fourth, the prosperity gospel, though much reviled by the media and academics alike, deserves sustained attention. As the historian R. Laurence Moore demonstrated, religious outsiders have been integral to the making of American religious history. ${ }^{11}$ While the Faith movement strikes many scholars as lying outside the bounds of respectable academic attention, I argue that the prosperity gospel is a decisive theological, economic, and social force shaping American religion.

\section{Historiography}

This route charts a familiar path through American religious history: that the clearest course through the tangles of American religion tracks evangelical movements and ideas. In this way, I am indebted to Edith Blumhofer, Joel Carpenter, Nathan Hatch, George Marsden, Mark Noll, Grant Wacker, and all those who have brought that story to life. But the prosperity gospel also exhibits cultural traits that characterize other religious

\footnotetext{
${ }^{9}$ For two contrasting $17^{\text {th }}$-century examples, see how New England Puritans sought to maintain their covenant with God to uphold their fledgling society, while New Mexican Pueblo Indians understood harmonious social relations as the lynchpin of their survival. See Edmund Morgan, The Puritan Dilemma (New York: Longman, 1999); Ramon Gutiérrez, When Jesus Came, the Corn Mothers Went Away (Stanford: Stanford University Press, 1991).

${ }^{10}$ For example, Anabaptists such as Hutterites, Mennonites, Amish, and Brethren often renounced individual wealth as part of their protest to mainstream culture.

${ }^{11}$ R. Laurence Moore, Religious Outsiders and the Making of Americans (New York: Oxford University Press, 1986).
} 
traditions that find their bearings on American soil. This story follows the Faith movement down the many rabbit holes that mark American civil religion. This version of civil religion does not focus on the sacralizing of the founding of the United States or on visions of manifest destiny, but on the deifying and ritualizing of the American Cinderella story: upward mobility, accumulation, hard work, and moral fiber. And lastly, following Catherine Albanese, this story includes metaphysical religion as key to the telling of American religious history in general, and the American Faith movement in particular. Metaphysical religion focuses on the relationship between the human mind and the spiritual universe, and the transference of energy that links one to another. Metaphysical New Thought infused Christian language with new power as believers came to believe that their minds could alter the material order. Albanese once observed that New Thought sought Mind, while evangelicalism sought Heart. In the end, the prosperity gospel refused to do without either one. ${ }^{12}$

\section{Finding Faith}

By 2010, only a handful of churches identified themselves as "Faith" or "Word of Faith" congregations, preferring to call themselves evangelical, charismatic, Pentecostal, or, most frequently, nondenominational. African American churches often bucked these trends and kept denominational markers. The absence of a common self-identifying label made the process of selecting prosperity churches an interpretative challenge. I searched sermons, Web sites, publications, conference schedules, mission statements, church rosters, and newspaper articles for theological, associational, and institutional connections among churches. In most cases, I focused on the ministry of the senior

\footnotetext{
12 This book contributes to Catherine Albanese's call for a "historiography of connection," particularly in tracing where "metaphysical" intersects with other religious traditions. The widespread influence of the American Faith movement gives further credence to Albanese's suggestion that evangelicals form the "backbone" of American metaphysical religion. Catherine Albanese, A Republic of Mind and Spirit (New Haven, CT: Yale University Press, 2007), 7, 510.
} 
pastor, as the lion's share of megachurches remained under the leadership of their founding pastor. ${ }^{13}$ Among the nation's largest churches, I identified eighty-six Faith congregations from a comprehensive list of all national megachurches created by Scott Thumma of the Hartford Institute for Religion Research (See Appendix). ${ }^{14}$ The evidence makes clear that participation in the Faith movement did not preclude involvement in other religious spheres, as each church and pastor simultaneously shared this Faith identity with other, overlapping allegiances. The famous healer Benny Hinn, for example, represented not only the consummate Faith teacher, but also fell within the theological and institutional parameters of Pentecostalism and both the charismatic and Apostolic movements. Most of the people in the dissertation might have easily appeared in a history of wealth in Pentecostalism.

This work goes beyond denominational history because the prosperity gospel's influence extended beyond formal church structures into what the historian Peter Williams called "extra-ecclesiastical," namely, popular religion. ${ }^{15}$ The prosperity gospel possessed the mass appeal of popular religion in spades, with unmatched audiences for prosperity books, conferences, and television programming. Further, it served as a religion "of the people," as millions discovered its message outside of Sunday mornings on their televisions or in the latest paperback. Prosperity teachers fostered an antielitism and, often, an antagonism toward "traditional" Christianity, preferring to win in the spiritual marketplace rather than the seminaries. ${ }^{16}$

\footnotetext{
${ }^{13}$ According to megachurch scholars Thumma and Travis, 83 percent of all megachurches churches grew dramatically during the tenure of the current pastor. Scott Thumma and Dave Travis, Beyond Megachurch Myths (San Francisco, CA: Jossey-Bass, 2007), 59.

14 This list of megachurches was assembled by Scott Thumma, Hartford Institute for Religion Research, http: / hirr.hartsem.edu/index.html (accessed January 1, 2010).

${ }^{15}$ Peter W. Williams, Popular Religion in America: Symbolic Change and the Modernization Process in Historical Perspective (Englewood, NJ: Prentice-Hall, Inc., 1980), 2-5. For a historiographical survey of the spirited debate on the use of the term "popular religion," see Charles H. Lippy, Modern American Popular Religion: A Critical Assessment and Annotated Bibliography (Westport, CT: Greenwood Press, 1996), 3-14. ${ }^{16}$ This distancing from seminaries stemmed from personal experience. Prosperity megachurch pastors, with few exceptions, possessed less formal education than their mainline and evangelical counterparts. Pastors instead bore their ministries on their backs by their charisma.
} 
The prosperity gospel's wide appeal left scholars with a formidable task. Reliable estimates of the total number of Faith churches, particularly small congregations, have not yet been ascertained, and data concerning the ethnicity, gender, and economic class of Faith believers remains murky. This work begins with megachurches and Faith celebrities, not only because megachurches propel much of the prosperity movement, but also because existing data on megachurches makes such work possible. Their features point to broader denominational and institutional trends of the nation's thousands of prosperity churches.

\section{An Introduction to the Faith Movement}

Before we begin at the beginning, as the King in Alice's Adventures in Wonderland advised, we will go on until we come to the end: then stop. Here we take a brief look at the features of the contemporary prosperity movement before we turn back to answer the question: how did we get here? The Faith movement's largest churches exhibited durable regional, denominational, institutional, and associational connections. Throughout, the Faith movement linked thousands of congregations and millions of believers, not as a uniform, uni-directional whole, but as a diverse, multi-directional movement.

The prosperity gospel exerted tremendous influence on American religious life, in part, because its largest congregations captured a significant portion of the spiritual market share. In 2010, approximately 1,300 American churches gathered 2,000 or more weekly attenders, a distinction that earned them the title of "megachurch." Faith churches crowded the upper echelon of national megachurches, claiming a high concentration of America's largest churches. Prosperity giants like Joel Osteen and T. D. Jakes led the first and eleventh largest churches, respectively, with Osteen's Lakewood Church doubling the attendance of its nearest competitor. Thirty percent of country's 50 
biggest churches followed Faith teachings. One fifth of these contained more than 10,000 attenders (see Figure 1).

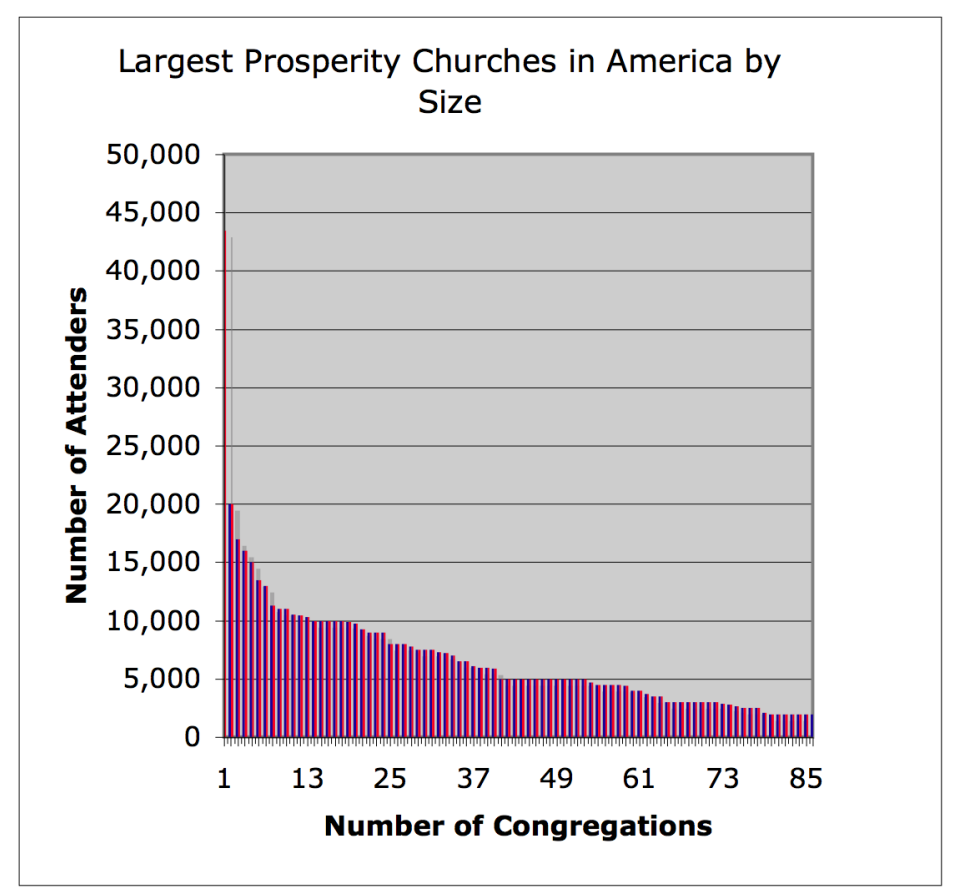

Figure 1: Prosperity Megachurches by Size. The average congregation contained 6,834 members.

The Faith movement's place at the top gave it surprising reach. The sociologist Mark Chaves of the National Congregations Study demonstrated that roughly 45 percent of worshippers attended the largest 10 percent of churches. ${ }^{17}$ Since the 1970 s, Americans have gravitated toward the biggest churches, placing more worshippers and financial donations in fewer houses of worship. The top 1 percent alone contained 15 percent of America's churchgoers. ${ }^{18}$ As seen in Table 1 below, prosperity megachurches dominated the upper tiers of megachurches nationally, with more than 60 percent of their congregations exceeding 5,000 members, as compared with 12 percent of all megachurches. The average prosperity church grew comparatively larger, granting it a

\footnotetext{
${ }_{17}^{17}$ Mark Chaves, Congregations in America (Cambridge, MA: Harvard University Press, 2004), 17-21. ${ }^{18}$ Thumma and Davis, Beyond Megachurch Myths, 5-6.
} 
hefty portion of the nation's worshippers. As the smallest 50 percent of congregations drew only 11 percent of all American churchgoers, the majority of the resources were left to super-sized congregations. ${ }^{19}$ With a combined annual income of seven billion dollars and vast electronic audiences, American megachurches rivaled seminaries, denominations, and religious publishers as a major influence in American religious life. ${ }^{20}$ Hence, when the Faith movement won the pulpits of many of America's largest churches, it gained extraordinarily wide influence. Table 1: Prosperity Megachurch Distribution by Size Compared to
Megachurches Nationally.

$\begin{array}{lcc}\begin{array}{c}\text { Number of } \\ \text { Attendees }\end{array} & \begin{array}{c}\text { Percentage of } \\ \text { Prosperity } \\ \text { Megachurches } \\ 16.2\end{array} & \begin{array}{c}\text { Percentage of All } \\ \text { Megachurches }\end{array} \\ 2,000-2,999 & 12.8 & 53.8 \\ 3,000-3,999 & 9.3 & 19.1 \\ 4,000-4,999 & 40.7 & 11.1 \\ 5,000-9,999 & 21.0 & 12.0 \\ 10,000 \text { or more } & & 4.00\end{array}$

Regions

The prosperity gospel thrived in the urban south and southeastern states, as its largest congregations clustered around Dallas, Houston, and Atlanta. Many of the bestknown prosperity televangelists, young and old, black and white, spoke with a drawl. Black celebrities like Eddie Long, T. D. Jakes, Creflo Dollar, and I. V. Hilliard ruled over the urban South. White favorites Joel Osteen, John Hagee, and Kenneth and Gloria Copeland, to name a few, made Texas home to some of the country's largest ministries.

\footnotetext{
${ }^{19}$ The total number of prosperity megachurches was meager in comparison with the total of megachurches (and the 335,000 of all American congregations). Thumma and Travis, Beyond Megachurch Myths, 2.

${ }^{20}$ Ibid.

${ }^{21}$ All national megachurch data used for comparison drawn from Thumma and Travis, Beyond Megachurch Myths, 8 (see Table 1.2).
} 
Oklahoma's Rhema Bible Training Center and Oral Roberts University further reinforced its strong southern character.

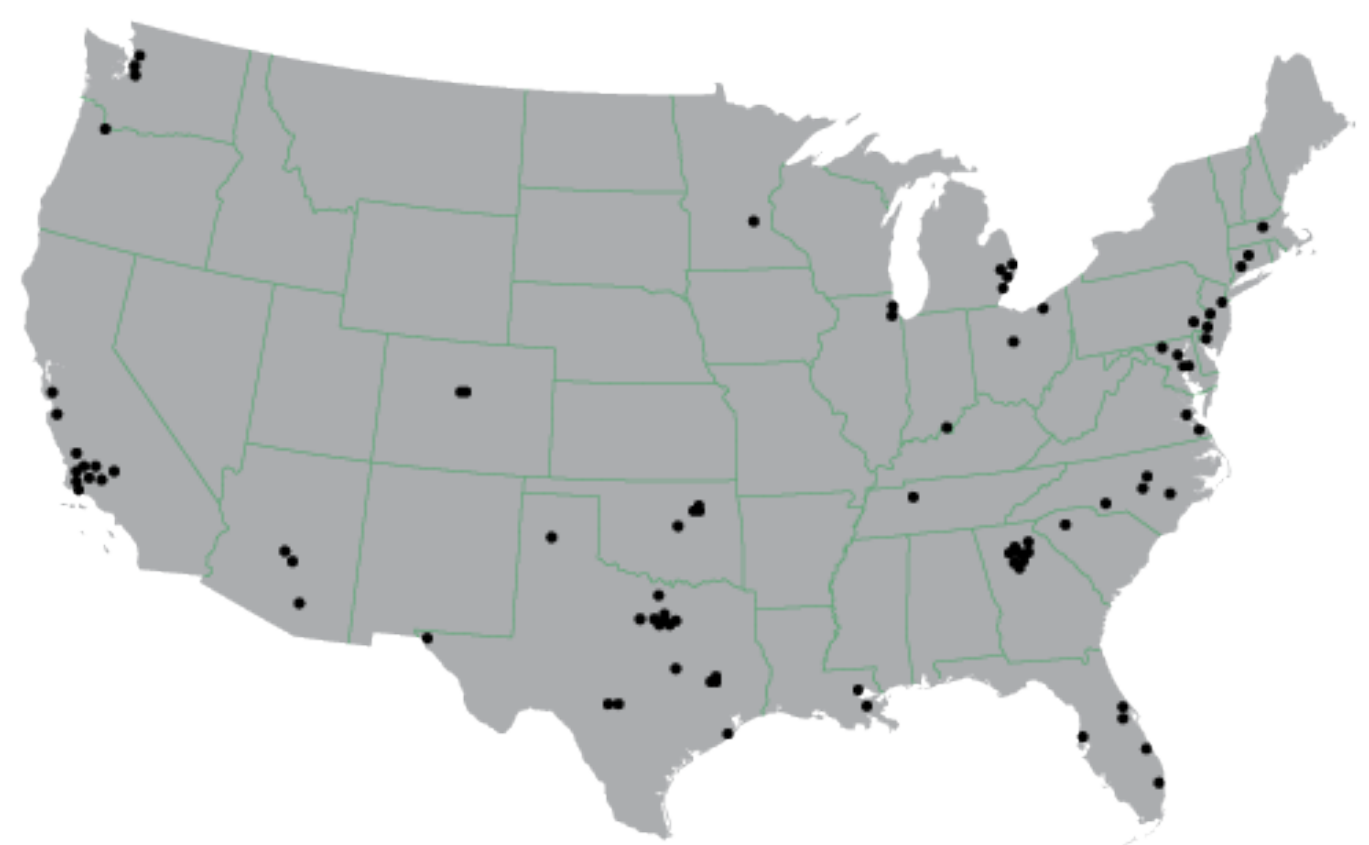

Figure 2: Prosperity Megachurch Locations in Mainland United States. The highest number of prosperity megachurches resided in Texas (11), followed by California (9), and Georgia (8). 


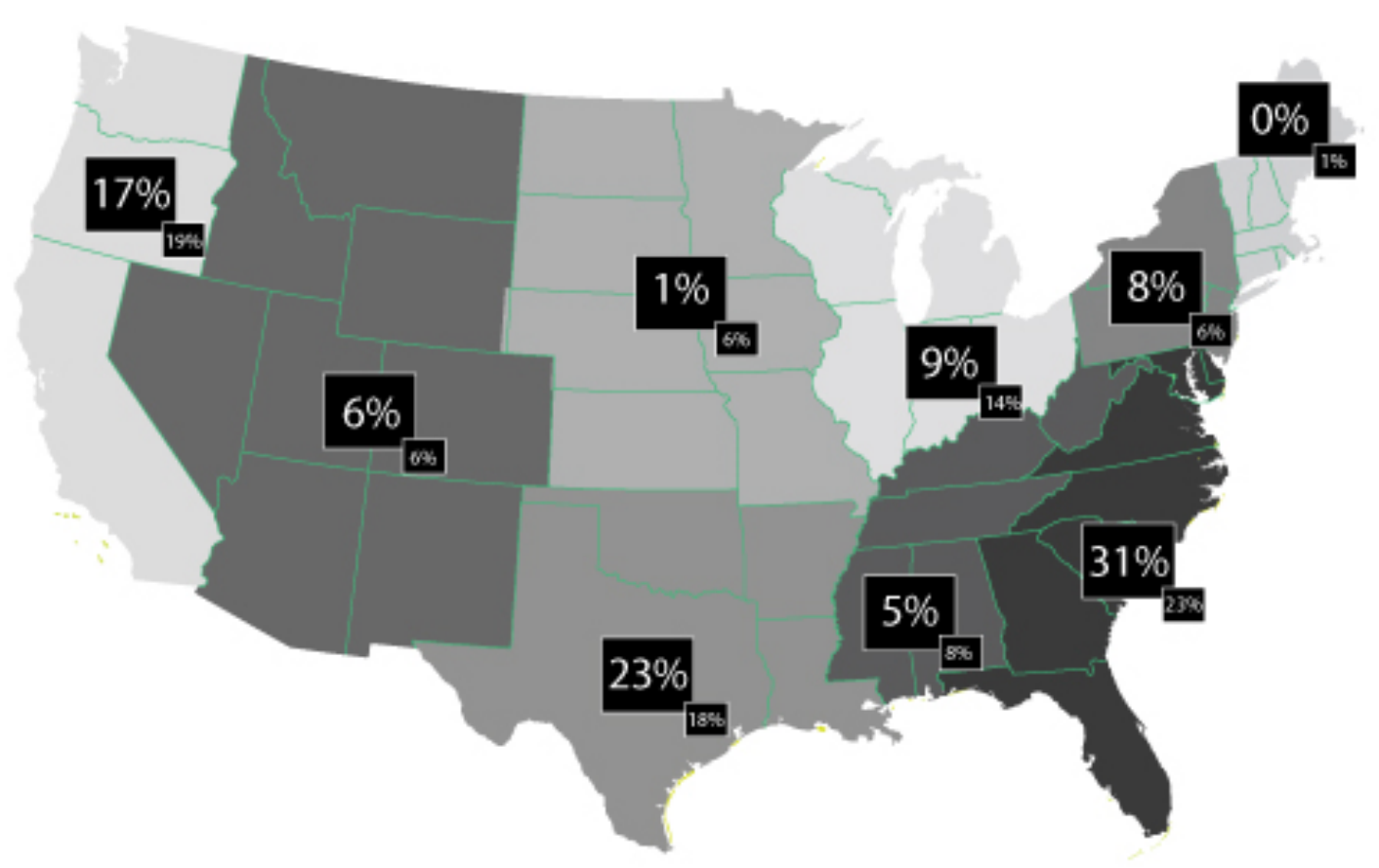

Figure 3: Regional Distribution of Prosperity Megachurches Compared with Megachurches Nationally. Prosperity megachurches are concentrated in the West, South, and Southeast. ${ }^{22}$

The Faith movement followed the broader trends of megachurch growth when, in the 1980s, prosperity congregations began to show signs of rapid growth outside of the American Sunbelt. ${ }^{23}$ As seen in Figure 3, Faith churches popped up across the United States. Michigan, California, Florida, and Washington, in particular, became new centers of prosperity theology, as their booming churches supplied an increasing share of the movement's national leadership. Whether in Minneapolis, Minnesota, or Sayreville, New Jersey, these leaders were homegrown celebrities, locals able to meet the particular needs of their religious marketplace. In 1980, Casey and Wendy Treat, for instance, founded

\footnotetext{
22 The regional distribution of national megachurch data, used for comparison, comes from Thumma and Travis, Beyond Megachurch Myths, 9 (see Figure 1.1).

${ }^{23}$ Thumma and Travis, Beyond Megachurch Myths, 26.
} 
the Christian Faith Center of Seattle in largely unchurched Washington State. The Treats provided a fashionable and media-savvy service attuned to the area's secular ethos, becoming able participants in what the sociologist James Wellman calls the "new churching" of the Northwest. Wellman estimates that "sectarian entrepreneurs" like Treat garnered believers at rates higher than the population growth, and much higher than fellow religious conservatives. ${ }^{24}$ These local heroes seemed better able to keep their ears to the ground.

The Faith movement met uneven success. The Northeast, for instance, proved to be stony ground. Though smaller Faith megachurches took root there, the largest ones did not. ${ }^{25}$ The Mountain states proved equally inhospitable, confirming the impression that the prosperity gospel favored cityscapes over wide-open spaces. ${ }^{26}$ Though prosperity churches sprouted more quickly in the South, the movement's regional successes showed it to be a national phenomenon.

\section{Denominations and Ethnicity}

At first glance, America's prosperity megachurches evinced few commonalities. Of all prosperity megachurches (see Figure 5), two thirds claimed no denominational affiliation. Upon closer examination, Pentecostalism emerged as the most frequent denominational subtext. From the prosperity gospel's inception in the 1950s to its

\footnotetext{
${ }^{24}$ The ranks of prosperity believers have grown sharply in the last two decades. Wellman estimates that these entrepreneurs hold five percent of the Northwest's spiritual market share. James K. Wellman Jr. "The Church of the Pacific Northwest: The Rise of Sectarian Entrepreneurs," Religion E Public Life in the Pacific Northwest: The None Zone (Walnut Creek, CA: AltaMira Press, 2004$), 87$.

${ }^{25}$ In 2009, New England supported ten megachurches, the smallest percentage of megachurches in the country. Of those, three professed Faith theology. Two were African American, and one multiethnic. Given the average New England Catholic parish holds 3,000 members, these numbers are humbling. Large churches in New England tend to hover at 500 to 1,000 souls. Yet the region may show some promise. Megachurch experts Scott Thumma and Dave Travis argued that North Eastern megachurches are growing more rapidly than in the South and West despite lower rates of population growth and concentration of megachurches. Thumma and Travis, Beyond Megachurch Myths, 26.

${ }^{26}$ The Mountain West experienced strong population growth in recent years but came to host only a small number of prosperity churches. This failure can be explained only in part by the region's general resistance to megachurches.
} 
widespread acceptance in the late 1970s, the Faith movement burst the seams of Pentecostalism. Its leaders preferred not to be hemmed in, moving in (but usually out) of denominational Pentecostalism at their leisure.

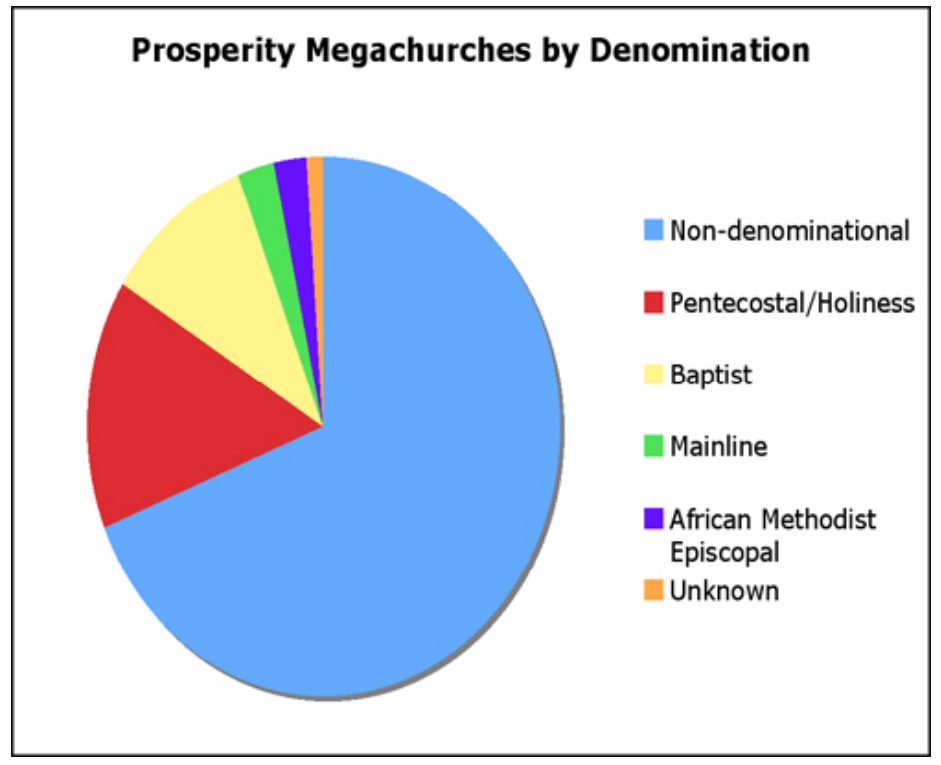

Figure 4: Prosperity Megachurches by Denomination. Nondenominational congregations dominated.

Most prosperity megachurches, chafing against denominational strictures, preferred to be officially nondenominational. As Jackie David Johns observed, these independents stressed congregational autonomy but excelled at networking for the purposes of fellowship and ordination. ${ }^{27}$ Faith televangelists, if no longer senior pastors, maintained Pentecostal denominational connections through spiritual mentorship, as another pastor would provide spiritual "oversight" to their ministry. Joyce Meyer, for instance, chose one of America's most famous Pentecostals, Tommy Barnett of the Assemblies of God, as her mentor, while television moguls Jan and Paul Crouch chose Foursquare President Jack Hayford. Almost all of the nation's prominent Faith teachers preached a Full Gospel message of speaking in tongues and gifts of the spirit. Yet the

\footnotetext{
${ }^{27}$ Jackie David Johns, “Pentecostalism,” eds. Erwin Fahlbusch, Geoffrey Bromiley, and David Barrett, The Encyclopedia of Christianity vol. 4 (Grand Rapids: Brill, 1999-2008), 142-3.
} 
prosperity gospel's theological hallmarks_Faith, Wealth, Health, and Victory-stretched the fabric of Pentecostal thought, and, frankly, added much that had not been there.

A variety of Pentecostal denominations appeared among the largest prosperity churches, including the Assemblies of God, Church of God in Christ, International Church of the Foursquare Gospel, and the oneness Pentecostal Assemblies of the World (See Table 2). Prosperity thrived within black Pentecostalism, and many Pentecostal denominations promoted Faith teachers to the highest ranks of leadership. ${ }^{28}$ In a recent survey, American Pentecostals responded with the highest level of enthusiasm for the prosperity gospel when compared with other Christians. Sixty-six percent of American Pentecostals (and 59 percent of charismatic believers) agreed that God granted and wealth. ${ }^{29}$ Among Pentecostal Latinos, the total leapt to 86 percent. ${ }^{30}$

Table 2: Percentage of Pentecostal Prosperity Megachurches Among All Faith Megachurches.

\begin{tabular}{|l|c|}
\hline \multicolumn{1}{|c|}{ Pentecostal Denominations } & $\begin{array}{c}\text { Percentage of all } \\
\text { Faith Megachurches }\end{array}$ \\
\hline Assemblies of God & 6 \\
\hline Pentecostal Assemblies of the World (Oneness) & 2 \\
\hline Church of God in Christ & 1 \\
\hline International Church of the Foursquare Gospel & 1 \\
\hline International Pentecostal Holiness Church & 1 \\
\hline $\begin{array}{l}\text { Pentecostal (unspecified) } \\
\text { Not all Prosperity churches were Trinitarian, as Oneness denominations like the Pentecostal } \\
\text { Assemblies of the World gave the movement theological scope. }\end{array}$ \\
\hline
\end{tabular}

${ }^{28}$ Faith teacher Charles Ellis III, pastor of the Detroit megachurch Greater Grace Temple, served as the Assistant Presiding Bishop of the Pentecostal Assemblies of the World. In 2009, the Church of God in Christ appointed prosperity preacher Bob Jackson, pastor of Acts Full Gospel Church, as the Jurisdictional Bishop for Mexico.

${ }_{29}$ The Pew Forum on Religion and Public Life, "Spirit and Power: A 10-Country Survey of Pentecostals," October 2006. http:/ / pewforum.org/publications / surveys / pentecostals-06.pdf (accessed January 8, 2010). 30 "Changing Faiths: Latinos and the Transformation of American Religion," (2006 Hispanic Religion Survey) http: / / pewforum.org/newassets / surveys / hispanic/ hispanics-religion-07-final-mar08.pdf (accessed January 7,2010$)$. 
Faith theology also made a powerful impact on historically black denominations, with celebrity Faith teachers commanding the pulpits of African Methodist Episcopal and Baptist houses of worship. ${ }^{31}$ Unlike their white counterparts, the "new black charismatics," as the historian Scott Billingsley called them, flourished inside as well as outside of denominational structures. ${ }^{32}$ The fearless ones struck out alone. In 1994, Paul Morton and likeminded Faith teachers broke away from the National Baptist Convention to form their own denomination, the Full Gospel Baptist Church Fellowship. Although some famous black preachers had been educated and promoted by Rhema Bible Training Center and Oral Roberts University, the African American Faith movement drew strength from multiple sources. Independent African American churches and leaders proved adept at supporting, educating, and promoting one another. Their inflating churches predictably centered in urban black centers like Chicago, Detroit, Los Angeles, and Atlanta, home to the highest number of megachurches and African Americans. Almost a decade into the new millennium, black megachurch and itinerant preachers still towered over the urban spiritual landscape. ${ }^{33}$

America's largest prosperity churches proved to be far more racially diverse than megachurches nationwide. According to Thumma and Travis, megachurches in the United States reflected the racial composition of the population: a majority of white churches with 10 to 12 percent African American, and 2 percent Asian minorities. Only Latino megachurches lagged behind at 2 percent of the population, far short of their 15 percent share of the population. ${ }^{34}$ America's largest prosperity churches were almost evenly split between black and white. Though African American churches comprised

\footnotetext{
${ }^{31}$ Both Kenneth Marcus's Turner Chapel AME Church and Jamal Harrison-Bryant's Empowerment Temple AME Church serve as examples.

${ }^{32}$ Scott Billingsley, It's a New Day: Race and Gender in the Modern Charismatic Movement (Tuscaloosa: University of Alabama Press, 2008), 104-129.

${ }^{33}$ Jonathan L. Walton, Watch This! The Ethics and Aesthetics of Black Televangelism (New York: New York University Press, 2009), 106-107.

${ }^{34}$ Thumma and Travis predicted that the swelling number of Latino immigrants would soon lead to commensurate numbers of Latino megachurches.
} 
only 10 to 12 percent of the total number of megachurches, they made up 42 percent of prosperity megachurches.

Though I found no strictly Latino megachurches, several prominent Latino pastors led thriving multicultural congregations. Further, as Latino prosperity denominations such as Maranatha Ministries now claim several hundred American congregations, it will only be a matter of the time before the Latino prosperity gospel comes to fruition. In the meantime, many megachurches cultivated Latino membership by hiring diverse staff and launching Spanish-speaking ministries. For example, Joel Osteen's Lakewood Church self-consciously appealed to a multiracial crowd. In 2007, Osteen reported that his congregation shared equal numbers of people of European, African, and Latin descent. Marcos Witt, winner of four Latin Grammys, joined the congregation in 2002 to lead Lakewood's Hispanic ministry, a popular draw for Texas's burgeoning Latino / a population. His Spanish services, attended largely by first- and second-generation immigrants from Mexico and Central America, served one of America's largest Hispanic congregations. Israel Houghton, Grammy-winning worship pastor at Lakewood, bridged the black-white divide as one of nation's most high-profile biracial Christian artists, bringing a fusion of gospel, rock, and jazz to Sunday services. Preliminary evidence suggests that Spanish language ministries will garner significant results. A recent Pew study found that 83 percent of Spanish-speaking participants agreed that God rewards believers with health and wealth, as compared with only 54 percent of English-dominant Latino/as. ${ }^{35}$

\footnotetext{
35 “Changing Faiths: Latinos and the Transformation of American Religion," (2006 Hispanic Religion Survey) http: / / pewforum.org/ newassets / surveys / hispanic/ hispanics-religion-07-final-mar08.pdf (accessed January 7, 2010).
} 


\section{Ministerial Connections}

The Prosperity gospel can be understood as a cohesive movement also by its institutional connections. As we have seen, celebrities like Osteen and Jakes created vast networks of seemingly independent ministries. These connections commonly appeared in two ways. First, many prosperity pastors were connected through their seminary training, as a particular stream of the prosperity gospel was taught and maintained through alumni associations. A second means of networking occurred through a performative web: a host of conferences, television programs, speaking tours, books, podcasts and DVDs, in which pastors promoted their own ministries and those of religious allies. The considerable engine of this movement, which propelled hundreds of American churches into the prosperity gospel, relied on its institutional parts acting as a mutually reinforcing whole.

Alongside denominational structures, new types of ministerial organizations bound churches into Faith networks. These ministerial organizations took two major forms. The first offered ministerial credentials, extending a government license of ordination, as well as a theological vetting of candidates. Dozens of these organizations promoted Faith ministries, forming links among hundreds of otherwise independent churches. Organizations like the Association of Faith Churches International (AFCI), founded in 1978 by Jim and Kathleen Kaseman, provided legal and spiritual accountability to its hundreds of member-churches. The second form of ministerial organization devoted attention to a particular Faith teacher, eschewing official licensing in favor of inspiration. Most Faith teachers oversaw a collectivity of smaller churches that turned to them for guidance, theological grist, and institutional support. These informal and voluntary associations gathered hundreds of congregations into loose affiliations that relied on the success of a charismatic leader. Creflo Dollar's Ministerial 
Association (CDMA), for instance, included several hundred American churches by 2008. Their website outlined the benefits of this loose organizational structure:

There are no governing bodies to report to or fear. There are no investigations or disciplinary actions to consider. CDMA is not interested in overseeing a church or outreach ministry. Each ministry must stand before God on its own. Our goal is to complement your assignment by making our expertise available to you. ${ }^{36}$

With few requirements-a shared belief statement and a yearly financial contributionthese structures accommodated numerous participants by providing members with exposure (albeit limited) to their role model. Their "complementary" and noncoercive function motivated countless local churches to join others in participating in the broader Faith movement.

Besides these ministerial organizations, two Bible schools proved to be important terminals in the prosperity movement. Rhema Bible Training Center, founded 1974, promulgated the pioneering prosperity theology of Kenneth E. Hagin, known as the "spiritual father" of the Faith movement. By 2008, Rhema Bible Training Center, centered in Tulsa, Oklahoma, claimed to have graduated nearly 30,000 ministers. ${ }^{37}$ Through Rhema Bible and his annual conferences, Hagin trained uncounted pastors in his "Word of Faith" strand of prosperity theology, offered ministerial credentials, and provided national exposure for his message and his protégées. Another Tulsa institution, Oral Roberts University, founded in 1963, also brought academic standing and ministerial credentials to the movement. Its founder, Oral Roberts-himself a popular Faith teacher after World War II-decorated countless fellow ministers with honorary Ph.Ds. Prosperity televangelists like John Hagee, Marilyn Hickey, Benny Hinn, Creflo Dollar, Kenneth Copeland, and Billy Daughterty dominated its board of regents until

\footnotetext{
${ }^{36}$ Creflo Dollar Ministries website, http:/ / interactive.creflodollarministries.org (accessed August 20, 2008).

${ }^{37}$ Rhema Bible Training Center, $w w w$ w.rhema.org (accessed August 1, 2008).
} 
2008, when scandal rocked the university's administration. ${ }^{38}$ All in all, Rhema Bible Training Center and Oral Roberts University energized the Faith movement, giving believers theological cohesion and shared platforms.

\section{A National Movement}

The Faith network formed an unequal grid of institutions, ministries, congregations, individuals and celebrities. Of its millions of participants, a cluster of leaders and megachurches formed the strongest nodes, densely connected conduits of the prosperity gospel. Most believers and congregations claimed some connection to these celebrated pastors, either by watching their television programs, reading their books, attending their conferences, or offering financial contributions. Denominations, ministerial associations, and Bible schools formed crucial junctions among scattered participants. Countless churches gathered at the periphery of the network. The Victorious Faith Center, for example, evinced weak but discernable connections through its use of Rhema Bible publications and its attendance at Pastor Creflo Dollar's local appearances. The pathways forged among participants varied in strength and longevity as associations constantly shifted. Region mattered, with believers concentrated in the Midwest, West, and especially the South. Though marked by difference in theological focus, region, gender, and race, American prosperity churches preached a message of Christian abundance, and, big or small, they looked to one another for financial support, theological inspiration, and institutional resources.

A marketplace ethos prevailed. After all, connections among churches and pastors remained largely voluntary, as most operated outside an umbrella of supervision. Smaller churches chose their affiliations selectively, often mixing-and-

\footnotetext{
${ }^{38}$ John W. Kennedy, “Healing ORU,” Christianity Today, September 2008.
} 
matching among pastors and institutions. Famous pastors lightly held onto their associations with one another, happy to share a stage briefly but never an organizational platform. As these teachers promoted their own ministries, they operated within a network that allowed for opportunity but did not enforce conformity. Celebrities who lost their appeal fell from their perches, while newcomers took their places. Nothing remained static. Yet their loose association with one another, bound up in shared ideas and institutions, formed the sweeping scale that can be called the Faith movement.

\section{Outline}

The following chapters pursue the prosperity gospel's message chronologically and thematically. Chapter One examines the origins of the American prosperity gospel as it drew from various theological streams and coursed through different denominational channels. Chapter Two traces its burgeoning theology of Faith from the postwar revivals to its maturity in the late 1970s. Chapter Three focuses on its pursuit of divine wealth from the 1980s onward as believers looked to their bank accounts for proof of their spiritual progress. Chapter Four examines divine health through the same lens, as believers used their bodies as barometers of Faith. Chapter Five explores the contemporary movement's expectation of victory, as participants oriented their lives

toward unimpeded progress. In short, the prosperity gospel proclaimed a message of Faith, Wealth, Health, and Victory. Inspired, they counted themselves blessed. 


\title{
Chapter One: Gospels
}

\author{
Confident living rights every wrong; \\ Dynamic power helps me be strong. \\ Confident living comforts my heart; \\ From such a blessing I can't depart. \\ “Confident Living," Unity School of Christianity (New Thought) hymn'
}

The roots of the prosperity gospel are long and tangled. To understand the size, success, and diversity of today's movement, we first need to understand certain ways of thinking about spiritual power that emerged and competed for attention early in the twentieth century. This thinking took many forms and went by different names, including mind-cure, success literature, positive thinking, self-help, and prosperity theology. This was the core: adherents, acting in accordance with divine principles, relied on their minds to transform thought and speech into heaven-sent blessings. It focused on the individual rather than groups and emphasized the power of the individual's mind. This chapter traces the development of this thinking about spiritual power in the metaphysical New Thought movement and its growth into more recognizably evangelical gospels of health and wealth. We might envision the prosperity gospel as comprised of three distinct though intersecting streams: New Thought, Pentecostalism, and African American religion. In this chapter, we see how these divergent traditions flowed across the American religious landscape and into new conduits of health and wealth.

Though little known outside of Pentecostal circles, the evangelist E. W. Kenyon serves as our journey's first guide. His evangelical appropriation of this concept of

\footnotetext{
1 Warren Meyer and Phoebe P. Knapp, “Confident Living," in Unity School of Christianity, Wings of Song (Unity Village, MO: Unity Books, 1984), no. 159, as quoted in Albanese, A Republic of Mind and Spirit, 423. 
spiritual power channeled New Thought and Pentecostal streams, shaping the Faith movement into, to borrow a title from Norman Vincent Peale, “A Guide to Confident Living."

\section{New Thought's Mental Magic}

From the beginning, Christians sought to access supernatural power for their daily lives, and the chief way they tried to do so was through prayer: requests from helpless humans to an omnipotent God who heard these pleas and might—or might not-answer them as desired by the petitioners. This formula required the pray-ers to acknowledge their own weak position and rely on the One with unlimited bounties. Finding this method and its subordination of the self to be irksome and ineffective Christians often sought to compel the supernatural to produce their desired results. Many hoped to manipulate the physical and spiritual planes through means that historians of religion have described as magic. Magic took two main forms, material and mental. Material magic, according to the historian Catherine Albanese, employed "spells, symbols, artifacts, and actions" to effect change, whereas mental magic made use of “vision, reverie, meditation, and affirmative prayer." ${ }^{2}$ Victorian America was a hotbed of mental magic, bursting with Transcendentalism, Spiritualism, Free Masonry, and, of particular interest here, New Thought. Out of this miasma came the thinkers who nurtured a particular species of mental magic, planting the seeds of the present-day prosperity gospel.

This type of mental magic surged in the late nineteenth century, accompanying confidence about the progress and potential perfectibility of the human race. The era after the Civil War, often known as the Gilded Age, witnessed a flood of religious ideals that bathed the period with hearty individualism and a bold pragmatism. Self-mastery

\footnotetext{
${ }^{2}$ Albanese, Republic of Mind, 7.
} 
became an art and occupation, as people sought to consolidate the era's advances with improvements to their own lives. An ethos of self-help prevailed: personal sewing machines and Popular Mechanics magazine bowed technology to house repair; at the same time, gymnasiums appeared in universities and city centers across the country, as people devoted themselves to the pleasure and pursuit of self-taught athletic conditioning. ${ }^{3}$ All signs seemed to point to the world's (and humanity's) hidden potential. New scientific discoveries like the telegraph, electric light, and "Koch's Postulates" - which demonstrated the role of germs in disease causation-introduced the American masses to invisible causal forces.

Ideas about the power of the mind ripened in this climate, the fruit of at least a half-century of metaphysical speculation. Ralph Waldo Emerson's (1803-1882) philosophical idealism, Swedish mystic Emmanuel Swedenborg's (1688-1772) Neoplatonic theory of correspondence, and Helena Blavatsky's theosophical quest for uniform spiritual laws seeded the ground, but it took Phineas Parkhurst Quimby (18021866), inventor and healer, to bring ideas about mind-power to maturity. ${ }^{4}$ Personal experience led Quimby part of the way. He attempted to cure his tuberculosis with some fresh air, but his carriage ride went awry when his horse balked, forcing him to run beside the horse. Surprisingly, the run offered relief of his symptoms, which signaled to Quimby that the mind could overcome disease. Quimby's suspicions about the power of

\footnotetext{
${ }^{3}$ Frederick Rudolph, The American College and University: A History (New York: Knopf, 1962), 151. For more on the Gilded Age and progress, see Paul A. Carter, The Spiritual Crisis of the Gilded Age (DeKalb, IN: Northern Illinois University Press, 1971), 157-175; Alan Trachtenburg, The Incorporation of America: Culture and Society in the Gilded Age (New York: Hill and Wang, 2007), 38-69.

${ }^{4}$ Following the historian Catherine Albanese, metaphysical religion replaces "occultism," "gnosticism," or "harmonialism" as the umbrella term for the European magical-religious traditions that, since colonial times, have been practiced on American shores. Encompassing elite and lay expressions, blended with American Indian, African American, and, later, Asian customs, metaphysical religion found expression in individual and communal pursuits of spiritual power. Drawing from Albanese, I definemetaphysical religion as spiritual power wielded to manipulate material and spiritual realms, drawing believers into personal restoration and connection to a greater spiritual plane. For examples of metaphysical religion's persistence in American culture, see David Hall's Worlds of Wonders, Days of Judgment (New York: Knopf, 1989); Jon Butler's Awash in a Sea of Faith (Cambridge, MA: Harvard University Press, 1990); and Catherine Albanese's magisterial A Republic of Mind and Spirit.
} 
the mind solidified as he shared his generation's obsession with mesmerism, a hybrid of healing practices and metaphysical thought, based on Franz Anton Mesmer's (17331815) discovery of hypnosis. Quimby followed in Mesmer's footsteps as a touring mesmerist; later, as a successful physician, he stumbled into discoveries about the human subconscious, including the effectiveness of placebos and the "talking cure," a forerunner of modern psychotherapy. The New England physician eventually concluded that healing occurred because of mental and spiritual alignment, inspiring a generation of positive thinkers to follow the connection between thought and healing. ${ }^{5}$

Mary Baker Eddy (1821-1910), founder of Christian Science, filtered Quimby's conclusions through a Christological framework. As Eddy taught, Jesus came to save the world, not through his divinity, but by demonstrating right thinking. He saw the earth as it truly was: an illusory material realm where the mind tricked people into dangerous misperceptions. The heart of Christianity was knowledge, and believers must be reeducated in the new mental science. Her 1875 manifesto Science and Health pressed beyond Quimby's mental science by breaking with any lingering materialism. She disavowed the reality of illness and even death, arguing that suffering resulted from mental errors. Believers must rid themselves of misperceptions that blocked mental and physical restoration. Eddy offered a compelling vision of divine health that promised a true Christian Science, spiritual truth with repeatable results. Yet not all who insisted on the power of the mind were willing to call the material illusory. American popular religion came to favor the productive tension of mind and body it found in Eddy's rival and successor: New Thought.

\footnotetext{
${ }^{5}$ For surveys of the development of New Thought, see Charles Samuel Braden, Spirits in Rebellion: The Rise and Development of New Thought (Dallas: Southern Methodist University Press, 1963), 47-88; Ann Taves, Fits, Trances, $\mathcal{E}$ Visions: Experiences Religion and Explaining Experience from Wesley to James (Princeton, NJ: Princeton University Press, 1999), 212-232; Donald Meyer, The Positive Thinkers: Popular Religious Psychology from Mary Baker Eddy to Norman Vincent Peale and Ronald Reagan, (Middletown, CT: Wesleyan University Press, 1988), 32-128.
} 
New Thought represents a cluster of thinkers and metaphysical ideas that emerged in the 1880s as the era's most powerful vehicle of mental magic. Three aspects of New Thought became foundational to the formation of prosperity mental magic. First, it assumed essential unity between God and humanity, declaring that separation from the divine was only a matter of degree. In Christian terms, this meant that "salvation" would not be an act imposed from above by God, but rather an act of drawing out humanity's potential. Second, New Thought taught that the world should be reimagined as Thought rather than substance. The spiritual world formed absolute reality, while the material world was the mind's projection. Unlike Christian Science, New Thought never denied the reality of the material world, but saw it as contingent upon the mind. Right standing with the divine required sacred alignment, a mystical connection that won the historian Sydney Ahlstrom's famous label of "harmonial religion." ${ }^{6}$ Third, New Thought argued that people shared in God's power to create by means of thought. People shaped their own worlds by their thinking, just as God had created the world using thought. Positive thoughts yielded positive circumstances, and negative thoughts yielded negative situations. ${ }^{7}$ These three features-a high anthropology, the priority of spiritual reality, and the creationist power of positive thought-formed the main presuppositions of the developing mental magic.

In its infancy, New Thought was largely preoccupied with the same issue that consumed Christian Science and the wider American culture: healing. Like hydropathy, Grahamism, Adventism, homeopathy, Spiritualism, and the burgeoning faith cure movement, New Thought offered a religious alternative to the often-harsh regimen of standard medical treatments. Bloodletting, mercury-laced purgatives, or arsenic tonics

\footnotetext{
${ }_{7}^{6}$ Sydney Ahlstrom, A Religious History of the American People (London: Yale University Press, 2004), 1019.

7 Beryl Satter, Each Mind a Kingdom: American Women, Sexual Purity and the New Thought Movement, 18751920 (Berkeley: University of California Press, 1999), 2.
} 
formed common "cures," making orthodox medicine a potentially risky treatment. Warren Felt Evans, New Thought's first author, promulgated the physical benefits of this therapeutic brand of metaphysics with the publication of The Mental Cure in 1869.

Evans, as a practicing healer and systematizer of New Thought, sought to explain illness as an imbalance resulting from wrong thinking. William James labeled these buoyant ideas, "the religion of healthy-mindedness." ${ }^{8}$ We turn now away from the wholly metaphysical gospels of health to a healer on the margins of Pentecostalism, whose blend of New Thought with evangelical theology produced a new Christian stream of mental magic.

\section{E. W. Kenyon}

Essek William Kenyon (1867-1948), called the grandfather of the Faith movement, flatly rejected the "religion of healthy-mindedness" as a counterfeit. ${ }^{9}$ In his fifty-five years as a revivalist, educator, and evangelist in areas of New Thought's greatest influence, he railed against it as a substitution of gospel truth with abstract “principles." ${ }^{10}$ Only Christians' rightful use of divine principles could unlock God's treasury of blessings, and Kenyon endeavored to teach them how. He called it "dominating faith." ${ }^{11}$ His foundational works on spiritual power articulated a set of universal laws that electrified late-nineteenth-century evangelicalism and its offspring,

\footnotetext{
8 William James, The Varieties of Religious Experience (Cambridge, MA: Harvard University Press, 1985), 71-108. See Albanese, Republic of Mind, 413-423.

${ }^{9}$ Kenyon's relationship tometaphysical religion, and particularly to New Thought, has been the topic of heated debate. Scholars like Dan McConnell argue for the "Kenyon Connection" to New Thought, a direct appropriation of metaphysical religion learned at Emerson College. In this analysis, the resulting prosperity gospel became a "facade of orthodoxy" applied to a cultic religion, making "Kenyonism" a "different Gospel." See D. R. McConnell, A Different Gospel (Peabody, MA: Hendrickson Publishers, 1988), 15-56. Others situated it firmly within the confines of radical evangelicalism, free from non-orthodox influences. Following Kenyon biographers Dale Simmons and Geir Lie, I find compelling evidence that Kenyon appropriated metaphysical religion more selectively and "evangelically" than McConnell and others have detailed. Dale H. Simmons, E. W. Kenyon and the Postbellum Pursuit of Peace, Power, and Plenty (London: Sca recrow Press, 1997) and Geir Lie, E. W. Kenyon, Cult Founder or Evangelical Minister? (Oslo: Refleks Publishing, 2003).

${ }^{10}$ Simmons, E. W. Kenyon, xii.

${ }^{11}$ Kenyon, The Two Kinds of Faith: Faith's Secret Revealed (Lynnwood, WA: Kenyon's Gospel Publishing Society, 1998), 22.
} 
Pentecostalism, with confidence in human capabilities.

Kenyon took a circuitous path to ministry. He showed early promise when, as a teenager, he served as a preacher and deacon in the Methodist church of Amsterdam, New York. When his spiritual ambitions fizzled, he embarked on a career as organ salesman, and then as an actor, before he enrolled in dramatic studies at Boston's Emerson College of Oratory. The college's theological impact on Kenyon is a subject of ongoing debate. Yet his tenure at Emerson, home to the New England sage Ralph Waldo Trine and other metaphysical teachers, certainly brought him into contact with the New Thought movement. ${ }^{12}$ In 1893, Kenyon married Evva Spurling, an agnostic and divorcée nine years his senior. Shortly after marriage, Kenyon and his new wife embraced the teachings of Keswick Higher Life and took up the ministerial mantle. He immersed himself in the work of evangelicals like D. L. Moody, R. A. Torrey, Hannah Whitall Smith, and Charles Cullis, and tied himself to the ministries of Christian and Missionary Alliance founder A. B. Simpson (1843-1919) and Boston pastor A. J. Gordon (183695), in whose church the Kenyons came to Higher Life. ${ }^{13}$ For almost a decade, the Kenyons lived as faith healers and ministerial nomads. Kenyon held various Baptist pastorates in Massachusetts, and the couple traveled as evangelists. He became increasingly committed to living by faith, surrendering his livelihood and his possessions for common use. In 1900, Kenyon founded Bethel Bible Training School in Spencer, Massachusetts, using as a model the Faith Training College of faith cure leader Charles

\footnotetext{
${ }^{12}$ Kenyon's gospel was certainly not the first evangelical brush with metaphysical religion. In the 1850s, Holiness revivalism caught wind of Swedenborg's writings, whose theology of correspondence swept over Oberlin. (See Simmons, E. W. Kenyon, 90.) As Candy Gunther Brown pointed out, Methodist leader Phoebe Palmer's husband, Walter, and the divine health advocate Charles Cullis were homeopathic physicians, suggesting an unexplored connection between the Holiness movement and homeopathy (Candy Gunther Brown, personal communication, June 15, 2009). For more on early evangelicals ties to vitalist movements, see W. R. Ward, Early Evangelicalism: A Global Intellectual History, 1670-1789 (Cambridge: Cambridge University Press, 2006). Catherine Albanese argued that a Holiness suspicion of "matter" led some of embrace "spirit" in metaphysical ways. Nazarene founder Phineas F. Bresee, for example, eventually drifted into theosophy. See Tamar Frankiel, "Ritual Sites in the Narrative of American Religion," in American Spiritualities edited by Catherine Albanese (Bloomington, IN: University of Indiana Press, 2001), 42.

${ }^{13}$ Simmons, E. W. Kenyon, 23.
} 
Cullis. In 1914, Evva died after a prolonged illness; the same year, Kenyon married a young Nova Scotian named Alice Maud Whitney. In the early 1920s, the Kenyon family, now expanded with a son and daughter, left their fledgling school for California, where he again bounded between pulpits and evangelistic meetings with restless intensity. By 1930, Kenyon's ministry was a bittersweet success. He had two weekly radio programs and a thriving congregation, but his marriage ended in divorce. ${ }^{14}$ In 1931, he departed for Washington state where he founded the New Covenant Baptist Church and a radio program “Kenyon's Church of the Air." In Washington, Kenyon's legacy found its home. His newsletter Herald of Life and Seattle Bible Institute began there. Apart from The Father and His Family and The Wonderful Name of Jesus, Kenyon published most of his major works during this period. On March 19, 1948, Kenyon died, likely from a lymphoid malignancy.

The scaffolding of E. W. Kenyon's theology stood on the bedrock of latenineteenth-century evangelicalism. Kenyon's evangelical piety would have passed muster in the Great Awakening, giving priority to the authority of the Bible, the experience of "new birth," the subsequent need for sanctification, and the necessity of evangelism. Radical evangelicals—and Kenyon with them-argued that sanctification conferred greater power than Christians had yet realized. ${ }^{15}$ In Christ's death and resurrection, believers could expect not only the new birth that marked the start of the Christian life, but also the transformation wrought by entire sanctification. The doctrine of entire sanctification sprang from the work of the eighteenth-century Englishman John Wesley (1703-91), who taught that God's grace might set believers on the road to perfect love for Christ by freeing them from the inclination to sin. The doctrine gained new

\footnotetext{
${ }^{14}$ Lie, E. W. Kenyon, 29.

15 The historian Grant Wacker offers the label "radical evangelicals" for the sundry believers (Baptists, Methodists, Presbyterians, Quakers, and Mennonites among them) that, at the turn of the twentieth-century, formed the lively denominational precursors to the Pentecostal movement. See Grant Wacker, Heaven Below: Early Pentecostals and American Culture (Cambridge, MA: Harvard University Press, 2001), 1.
} 
significance in (Wesleyan) Holiness and Reformed circles in the mid-nineteenth century, when believers began to depict entire sanctification not as a process but as a calculable moment. This baptism of the Holy Spirit, as it was, offered Kenyon a powerful vision of Christian victory over sin.

Quarrels over the timing of the sanctification experience later became one of the early Pentecostal movement's thorniest debates. Did it accompany or follow salvation? For E. W. Kenyon, the real question was one of power: What victories could the redeemed Christian expect over sin? Kenyon confidently claimed that Christ had secured not only sanctification but also a plethora of other blessings in the atonement. He preached this view to William H. Durham, who embraced it. Durham's 1910 sermon, later published as "Finished Work of Christ," ignited a firestorm of controversy that, by 1920, had won most Pentecostals to the view that sinners found salvation-justification and sanctification-in a single soteriological work of grace. ${ }^{16}$ Christ's atoning work may be finished, but for Kenyon this was not the end of the story. ${ }^{17}$ His theology held that this profound ontological shift from sinner to saint signaled only the first phase of redemption. To explain, Kenyon borrowed New Thought's focus on mind, spirit, and universal laws to show that Christians could look to the cross not as a promise of things to come, but as a guarantee of benefits already granted.

Christ's substitutionary atonement, according to Kenyon, underwrote a series of spiritual and legal transactions. In language reminiscent of New Thought, God was a Spirit who created a spiritual universe. The physical world was a shallow material reflection of this pre-eminent and pre-existing spiritual universe. Though clothed in the

\footnotetext{
${ }^{16}$ As Dale Simmons argues, Kenyon met Durham in 1907 (three years prior to Durham's published treatise on the subject) and considered Durham's Finished Work theology indebted to his own. Simmons, E.W. Kenyon, 293-294.

${ }^{17}$ Holiness, Higher Life, and (later) Pentecostal and charismatic adherents commonly held to the idea that God empowered Holy-Spirit led believers to lives of extraordinary witness and service, filled with power above and beyond the ordinary abilities granted to Christians.
} 
"temporary dwelling place" of flesh and bones, humans too were primarily spirit. ${ }^{18}$

Though the priority of spirit seemed to be a peripheral theological detail, Kenyon drew it into every beginner's course on the gospel. Without it, the cross became difficult to understand. In the Fall, Satan gained legal authority over Adam and became humanity's spiritual father, the consequences of which were sickness, poverty, and death. ${ }^{19}$ Without Christ, humanity resembled the inhabitants of Plato's cave, devoid of the light of revelation and "dependent upon [their] senses for [their] life and protection." ${ }^{20}$ Their dulled senses could not perceive or access the storehouse of blessing God intended for them. Christ's resurrection united humanity's spiritual nature with God's own, restoring their spiritual vision and legal rights to dominion over the earth. ${ }^{21}$ The power of sin was broken. Clear-eyed believers henceforth possessed God's ability and authority to rule over the material world.

Christians, now unburdened by sin, hovered only a little lower than angels. Kenyon's anthropology outstripped the boldness of even Higher Life teachers, who, as Kenyon biographer Dale Simmons observed, held up divine union with God as a distant goal. Kenyon understood it to be the starting point. ${ }^{22}$ Jesus' death and resurrection had shifted believers' ontological status, making them legal shareholders of certain rights and privileges. At times, Kenyon's Holy Spirit-filled Christians hardly could be identified as human at all, as their total identification with God approached deification. "The World has not known that there is a superman in their midst today," Kenyon marveled. "They

\footnotetext{
18 "Man is a spirit and possesses a soul and has a body. His soul and spirit constitute his personality. Above this soul is he, himself, spirit. This is the real Man." E. W. Kenyon, The Father and His Family: A Restatement of the Plan of Redemption (Lynnwood, WA: Kenyon's Gospel Publishing Society, 1998), 45. For a historical treatment of this theme in Kenyon's work, see Simmons, E. W. Kenyon, 97; Lie, E. W. Kenyon, 37-38.

${ }^{19}$ Lie, E. W. Kenyon, 37.

${ }^{20}$ E. W. Kenyon, The Two Kinds of Life (Lynnwood, WA: Kenyon's Gospel Publishing Society, 1983), 102.

${ }^{21}$ Lie, E. W. Kenyon, 45. This bifurcation between spiritual and physical worlds lent added meaning to Jesus' death. According to Kenyon, Satan "took Jesus' spirit with himdown to the pit of hell where Jesus during three terrible days and nights suffered the tortures of hell's cohorts." Lie, E. W. Kenyon, 43.

${ }^{22}$ Simmons, E. W. Kenyon, 99.
} 
don't know that every new creation is a superman in the embryo, that all that embryo needs to know what it is, what it can do, what the Father expects it to do, and what the Father has empowered it to be and to do in the world." ${ }^{23}$ Believers could not rise to the heights of spiritual supermen without the second phase of their redemption. ${ }^{24}$ The next step would be epistemological, as believers learned the inner workings of Faith.

Kenyon's theology of Faith took inspiration from his own involvement with the late nineteenth-century divine healing movement. ${ }^{25}$ Alternatively called faith cure, the movement thrived among evangelical Protestants, ordained and lay, from a variety of traditions. Charles Cullis (1833-92), author of Faith Cures, or Answers to Prayer in Healing of the Sick (1879), inspired a generation of leaders (particularly those in Higher Life and Holiness circles) to take up healing as another provision of the atonement. ${ }^{26}$ Kenyon's personal experience with healing paved the way. His conversion and subsequent healing within the Keswick Higher Life tradition made him into a preacher, but not a healer. ${ }^{27}$ Shortly after his conversion in A. J. Gordon's church, he relates that his "poor, sick, wrecked body was instantly made whole." ${ }^{28}$ Still, Kenyon was a reluctant minister for the gospel of health, worried about being called a fanatic. ${ }^{29}$ Yet Evva Kenyon's sheepish attempt at faith healing changed them both, when a

\footnotetext{
${ }^{23}$ E. W. Kenyon, Advanced Bible Course: Studies in the Deeper Life, $5^{\text {th }}$ ed. (Lynnwood, WA: Kenyon's Gospel Publishing Society, 1970), 133. I was not able to locate an original edition of this work, but evidence suggests that later editions varied little.

${ }^{24}$ E. W. Kenyon, New Creation Realities (Lynnwood, WA: Kenyon's Gospel Publishing Society, 1970), 51.

${ }^{25}$ For more on the roots of the healing movement see Donald W. Dayton, Theological Roots of Pentecostalism (Metuchen, NJ: Scarecrow Press, 1987); Joseph Williams, “The Transformation of Pentecostal Healing: 19062006" (Ph.D. dissertation, Florida State University, 2008).

${ }^{26}$ Heather Curtis, Faith in the Great Physician: Suffering and Divine Health in American Culture, 1860-1900, (Baltimore: The Johns Hopkins University Press, 2007), 8-9.

${ }^{27}$ The Keswick tradition, alternatively "Higher Christian Life," and "Victorious Christian Life," named for its 1875 holiness conference in Keswick, England, argued that sanctification (begun in conversion) allowed believers to live out a victorious (higher) life of Christian service. Some saw the experience as progressive, and others as episodic. Yet the Holiness, Higher Life, Pentecostal, and charismatic traditions that poured in to prosperity gospel agreed the Holy Spirit gave believers extraordinary power for witness and service. See Grant Wacker, "Pentecostalism," in the Encyclopedia of the American Religious Experience (New York: Charles Scribner's Sons, 1988), 2: 933-945.

${ }_{28}^{28}$ Simmons, E. W. Kenyon, 236.

${ }^{29}$ For Kenyon's reservations see Lie, E. W. Kenyon, 22-23; for an account of Evva's first healing, see Joe McIntyre, E. W. Kenyon and His Message of Faith: The True Story (Lake Mary, FL: Creation House, 1997$), 62$.
} 
tuberculosis-ridden man begged for and received healing after Evva's reluctant hands touched him.

In faith cure, Kenyon discovered the collaboration of faith, mind, and health. Though healing services, published treatises, and the founding of "faith" homes for the sick, faith cure advocates sought to overcome illness through the cultivation of faith. ${ }^{30}$ Illness, they taught, perished when a patient believed and then acted as one whom God has already healed. Practitioners were encouraged to pray the "prayer of faith," holding God to his guarantee of restored health for all who believe. As the historian Heather Curtis noted, devotional practices of health put faith in motion, "training the senses to ignore lingering pain or symptoms of sickness and disciplining the body to 'act faith' by getting out of bed and serving God through energetic engagement with others." ${ }^{31}$ This mental and physical exertion energized the work of faith, translating spiritual fervor into physical wholeness. Kenyon wholeheartedly agreed that Christians must live out their faith in contradiction to their senses. As Kenyon argued, humans, bombarded by "sense knowledge," must be trained to see the spiritual truths ("revelation knowledge") buried beneath. ${ }^{32}$ Faith laid claim to these hidden spiritual realities. Kenyon went even further and prescribed more than a faith cure to illness. Believers must not only nourish belief through action; they must unleash the spiritual forces that commanded the universe. Faith, as he defined it, was the "confident assurance based on absolute knowledge that everything is already provided through the operation of certain immutable laws." ${ }^{33}$ To explain how this came to be, Kenyon turned back to the beginning, creation. The story of creation accounted for both how God used faith and how humans were created for faith.

\footnotetext{
${ }^{30}$ Curtis, Faith in the Great Physician, 10. For more on Faith homes, see Nancy Hardesty, Faith Cure: Divine Healing in the Holiness and Pentecostal Movements (Peabody, MA: Hendrickson Publishers, 2003); Edith Blumhofer, "Life on Faith Lines: Faith Homes and Early Pentecostal Values." Assemblies of God Heritage 10 (Summer 1990): 10-12, 22.

${ }^{31}$ Curtis, Faith in the Great Physician, 12.

${ }^{32}$ See Kenyon, The Two Kinds of Faith, 10-31.

${ }^{33}$ Simmons, E. W. Kenyon, 150.
} 
"In the beginning was the Word." This familiar opening of John recapitulated the Genesis creation account, and, for Kenyon, summed up creation's most enduring feature: the spoken word. God spoke the world into existence, creating light with the words, "Let there be light." New Thought leader Charles Fillmore's first book, Christian Healing (1909), echoed Kenyon's work when he argued that God established the "original Creative Word" in Genesis, making the spoken word the template for activating power. ${ }^{34}$ Kenyon, however, stipulated that the divine power poured into the container of words could be called only one thing: faith. "Faith-filled words" not only brought the universe into being but also governed the world as an invisible force. ${ }^{35}$ The power of the spoken word simply carried faith to its desired ends.

The "Word" became a signifier with many referents. Kenyon accepted the customary meaning of Jesus Christ as the Word, both God himself and God's message to the world. Scripture housed God's written Word. Yet Kenyon gave priority to the spoken Word above all as the source of God's power. Believers speaking God's own Word gained access to the creative power that laid the foundations of the earth. He urged believers to use spoken words, called positive confessions, to tap into this spiritual power. "Faith never rises above its confession," he often repeated. ${ }^{36}$ Though Kenyon lambasted New Thought for their proclamations of "I am well, I am well, I am happy, I am happy," he chided their content, not their method. Kenyon advised them to repeat instead: "I am a child of the Living God." ${ }^{37}$ New Thought employed the right process with the wrong theology. God sought speakers, not simply believers. Even the unsaved, Kenyon mused, might enjoy the benefits of positive words. ${ }^{38}$

\footnotetext{
${ }^{34}$ Charles Fillmore, Christian Healing: The Science of Being (Unity Village, MO: Unity School of Christianity, 1950), 55.

${ }^{35}$ Kenyon, The Two Kinds of Faith, 20.

${ }^{36}$ Kenyon, The Two Kinds of Faith, 65.

${ }^{37}$ Simmons, E. W. Kenyon, 101.

${ }^{38}$ Simmons, E. W. Kenyon, 237.
} 
Just as the atonement transferred legal authority from Satan to the faithful, the name of Jesus held forensic significance. Kenyon taught that Jesus transferred the "Power of Attorney" to all those who use his name. Prayer took on binding legal qualities as believers followed Jesus' formula: "If ye shall ask anything in my name, I will do it" (John 14:14). Kenyon replaced the word "ask" with "demand," since petitioners were entitled to the legal benefits of Jesus' name. ${ }^{39}$ The Holy Spirit became merely an assistant as Kenyon gave the credit for casting out demons, speaking in tongues, and curing disease to the rightful use of the name of Jesus.

Kenyon's articulation of "overcoming faith" — evangelicalism sparked with mental magic - acted as a flint stone for generations of followers. Kenyon's theology preceded and then overlapped with Pentecostalism, and as it did, it brought underlying themes into sharp relief. Faith-filled believers became powerful conduits through which God's power could flow. His amplified anthropology, together with a priority on spiritual reality and the power of thought expressed in word and deed, provided the theological groundwork for some of the most radical Pentecostal claims to atonementpower. Kenyon's Finished Work theology, as articulated by William Durham, left a lasting imprint on Pentecostal ontology. Oneness Pentecostals (who understood Jesus alone as God) widely embraced his book The Wonderful Name of Jesus (1927) as an articulation of Jesus' singular expression of God's power. ${ }^{40}$ To be sure, Kenyon's theology represented only a minority strain within Pentecostalism. In his lifetime, Kenyon's Bethel Bible Institute, correspondence school, and evangelistic revivals earned him modest fame. Yet the wide reach of his books, periodicals, and national radio ministry gave him lasting theological influence. We can measure some of his fame. By the time of his death,

\footnotetext{
${ }^{39}$ Simmons, E. W. Kenyon, 167.

${ }^{40}$ Oneness Pentecostalism emerged in the late 1910 s as a minority tradition within Pentecostalism; it always placed more emphasis on the word Jesus than their Trinitarian counterparts. See Wacker, Heaven Below, 88. 
Kenyon's Herald of Life boasted a circulation of more than 20,000 people in nearly sixty countries. ${ }^{41}$ By the 1970s, Kenyon's Gospel Publishing Society sold 100,000 of his books per year. ${ }^{42}$ More indirectly, though no less consequentially, in the 1950s Kenyon's theology thrived in the publications of healing evangelists like Kenneth E. Hagin, the Faith movement "founder" who borrowed liberally from Kenyon's eighteen books. ${ }^{43}$ After Hagin popularized Kenyon's theology, the Faith movement relied on Kenyon's synthesis of Higher Life teachings with New Thought's mental magic.

\section{Pentecostalism's Mental Magic}

Early Pentecostals stood with their feet firmly planted in the material world. Though better known for their heavenly minded experiences of ecstatic worship, speaking in tongues, and focus on the Lord's imminent return, Pentecostals also distinguished themselves with radical claims about God's terrestrial blessings. Like their radical evangelical predecessors, they preached a "four-fold" gospel of divine healing, personal salvation, baptism of the Holy Spirit, and Christ's soon return. They claimed the human material body as a site of divine healing, blessing, and empowerment. As the Zion City evangelist John G. Lake observed, salvation was "an all-inclusive word, including all that God does for the spirit, soul, and body of man." ${ }^{44}$ It is not surprising then that many Pentecostals found Kenyon useful. Kenyon's relationships with some of the greatest Pentecostal leaders of the day-William Durham, Aimee Semple McPherson, John G. Lake, and F. F. Bosworth-led many to mistake him for a

${ }_{41}^{41}$ Geir Lie, E. W. Kenyon, Cult Founder or Evangelical Minister? (Oslo: Refleks Publishing, 2003), 30.

${ }^{42}$ Simmons, E. W. Kenyon, x.

43 McConnell documented Hagin's extensive borrowing from Kenyon's books.

44 John G. Lake, Spiritual Hunger and Other Sermons, ed. Gordon Lindsay (Dallas: Christ for the Nations, 1994), 19. 
Pentecostal. ${ }^{45}$ Though Kenyon kept Pentecostalism at arm's length, a strong minority of Pentecostals adopted Kenyon's instrumental vision of faith. ${ }^{46}$

Fred F. Bosworth, healing evangelist and radio pioneer, borrowed elements of Kenyon to form one of the most influential theologies of health. ${ }^{47}$ In the 1920s, Bosworth spread his message though popular revivals across the United States and Canada, as well as his Chicago-based radio program, National Radio Revival Missionary Crusaders. His bestselling manifesto, Christ the Healer, established Pentecostal orthodoxy concerning divine health: all right-thinking Christians may lay claim to perfect health. He offered a simple prescription to "act faith, speak faith, and to think faith." ${ }^{48}$ Like Kenyon, Bosworth urged readers to pray the "prayer of faith," and act on their healing "while every sense contradicts Him!" 49 The body served as a site of healing, blessing, and empowerment. Kenyon's vision of overcoming faith impacted him significantly. Bosworth shared Kenyon's conclusion that healing was a legal right, secured by Christ, and accelerated through spiritual effects of positive words. Confession, he wrote, "puts God to work fulfilling His promise" and brings believers' words into reality. He likened the process to a game of checkers: "our move is to expect what he promises . . before we see the healing. . . . He always moves when it is His turn." ${ }^{50}$ A believer's move forced God to move accordingly. Early Pentecostals (and quasi-Pentecostals like Bosworth and Kenyon) never cried out: “Lord, heal me if it be thy will!” The qualification marred

\footnotetext{
${ }^{45}$ Lie, Kenyon, 50. Kenyon attended the Azusa Street revival and even applied for ordination by the Assemblies of God in the mid-1920s. For unknown reasons, he never followed through. Simmons, Kenyon, 41. ${ }^{46}$ Kenyon's daughter claims that though hemaintained strong ties to Pentecostalism, he never spoke in tongues and did not consider himself a Pentecostal.

${ }^{47}$ Lie, E. W. Kenyon, 49. Kenyon's biographer Dale Simmons writes, “Precisely when Bosworth came into contact with the teachings of E. W. Kenyon is uncertain; however, Kenyon's daughter relates that the two met during one of Kenyon's visits to Chicago. Most likely, then, the two met before 1910." Simmons, Kenyon, 295. Further, Bosworth contributed articles to Kenyon's Herald of Life. Bosworth, like Kenyon, hovered on the margins of Pentecostalism. He withdrew from the Assemblies of God in 1918 because he could not endorse the hallmark doctrine that speaking in tongues was the initial physical evidence of the baptism of the Holy Spirit.

${ }^{48}$ Bosworth, Christ the Healer (Old Tappan, New Jersey: Fleming H. Revell Company, 1973), 143.

${ }^{49}$ F. F. Bosworth, Christ the Healer, 110. For reference to the "prayer of faith," see page 7; see 14-39 for references to Higher Life / Faith Cure leaders.

${ }^{50}$ Bosworth, Christ the Healer, 98-99.
} 
God's self-imposed promise with doubt. Bosworth parroted Kenyon's words: “A spiritual law that few recognize is that our confession rules us." ${ }^{51}$ Pentecostals would have to put their lips, as well as their hearts, to use.

Bosworth's gospel of health proved to be an important pillar of the Faith movement. Though Bosworth never preached prosperity, he placed the righteous individual, speaking faith-filled words, at the heart of divine healing. Like most Pentecostals, he appropriated New Thought mental magic. This theology might be called metaphysically inflected, filtered through a first generation of New Thought-inspired Pentecostals. His healing theology and revival techniques proved to be a textbook for later healing revivalists, cementing Kenyon's imprint on divine health long after his own ministry faded.

Yet Kenyon's theology also leavened Pentecostal ontology, as Pentecostals placed great emphasis on God's desire to perfect, not simply redeem, his followers. Their confidence in human perfectibility seemed limitless, as Pentecostals wondered how God-like they might become. Earlier we noted Kenyon's insistence that Christians who lived up to their spiritual benefits would become "supermen," and "world-ruler[s] in the spiritual realm." 52 To be sure, most lightly tempered their holy optimism with modesty, reminding one another that Christ alone deserved the glory. The historian Grant Wacker called this early Pentecostal confidence "psychological dynamite" for its claims of powerful access to divine authority. ${ }^{53}$

John G. Lake, the Zion City evangelist and missionary to South Africa, laid out one of the strongest Pentecostal cases for supra-human abilities. Credited with

\footnotetext{
${ }^{51}$ Unlike many others, Bosworth credited Kenyon for his words. The conclusion of "Our Confession" of Christ the Healer states: "Most of the thoughts expressed in this sermon I have brought together, by permission, from the writings of Rev. E. W. Kenyon." Bosworth, Christ the Healer, 148. See also Kenyon, The Two Kinds of Faith, 67.

${ }^{52}$ Simmons, E. W. Kenyon, 174.

${ }^{53}$ Wacker, Heaven Below, 96.
} 
pioneering "God-men" theology, Lake's bold claims teetered on self-apotheosis. "God intends us to be gods (John 10:34)," he argued. "There is a God-power and a soul-force in the nature of man that God is endeavoring to bring forth. ... The man within is the real man. The inner man is the real governor, the true man that Jesus said was a god." 54 Lake, like Bosworth, credited Kenyon and John Alexander Dowie as theological inspirations, and it is tempting to conclude that his soaring anthropology sprang mainly from faith cure and Kenyon's appropriation of mental magic. A lesser-known chapter of Lake's ministry, however, established a more direct link to New Thought. Prior to establishing his famous healing ministry in Spokane, Washington, Lake co-served a congregation with New Thought author Albert C. Grier, a partnership that began a lifelong collaboration..$^{55}$ The two shared a devotion to divine health and labored together in the church's "healing rooms," areas where trained church members ministered to the sick through counsel and prayer. Shortly thereafter, Lake founded "Healing Rooms," advertising "Dr. John Lake, Miracle Healing Power" free of charge to all seeking divine health. His ministry garnered national attention as reportedly 100,000 people claimed healing. ${ }^{56}$ Though Lake helped create healing room ministries, he clearly owed much to Grier's ministry and the healing rooms erected by Dowie in the late 1800s in Zion City. While Lake's biographer asserts that the evangelist preached an unequivocally Pentecostal message, Lake's comparatively stronger claims to spiritual power suggests that New Thought lit the fuse of Pentecostalism's psychological dynamite.

\footnotetext{
${ }^{54}$ Lake, Spiritual Hunger, 20. See also pp. 86, 90.

${ }_{55}$ In 1915, Lake founded his own congregation, comprised largely by former members of the New Thought congregation. Kemp Pendleton Burpeau, God's Showman: A Historical Study of John G. Lake and South African/American Pentecostalism (Oslo: Refleks Publishing, 2004), 152-53.

${ }^{56}$ For more on Lake's healing theology, see Johanes Lilik Susanto, "A Practical Theological Evaluation of the Divine Healing Ministries of Smith Wigglesworth and John G. Lake: A Continuationist Reformed Perspective," Doctor of Theology Thesis, University of South Africa, Pretoria, South Africa, June 2007, accessed at: http: / / etd.unisa.ac.za / ETD-db / theses / available / etd-06262008113048 / unrestricted / thesis.pdf, 100-106.
} 
Words spoken in prayer, exorcism, worship, or plain conversation took on added weight, as Pentecostals cultivated a popular theology and practice of verbal power. Their high opinion of the spoken word had begun on Azusa Street, as Pentecostals turned to glossolalia (speaking in tongues) as their spiritual seal. ${ }^{57}$ Eager believers demonstrated their divine connection not by doctrine or ritual, but by speaking in a holy language. ${ }^{58}$ Pentecostals stood out in the history of Christianity for they alone required an involuntary ecstatic utterance as a credential for ordination and full participation in the community. Pentecostals cemented the material character of glossolalia in doctrinal formulas as "the initial physical evidence of speaking in tongues." (emphasis added $)^{59}$ Early debates whether the deaf could speak in tongues using sign language pointed to their enthusiasm for the power of the spoken word and desire for all to participate. ${ }^{60}$ The absolutism that charged their doctrine with certainty and their actions with cosmic meaning also fixed words with ironclad import. These Pentecostals relied on prevailing prayer to transmit their pleas not as requests but as contracts, guaranteeing miraculous results. ${ }^{61}$ Believers ferreted out the meaning of God's many names for personal use. To the sick, for instance, God revealed himself as Jehovah-Rapha ("I am the Lord that healeth thee.") To the fearful, God's redemptive name was Jehovah-

\footnotetext{
${ }^{57}$ Other physical manifestations signaled the Holy Spirit's presence. For example, the Metropolitan Church Association, headquartered in Waukesha, Wisconsin, contributed some of the early Pentecostal leaders and the distinction of being called "The Holy Jumpers" because some of its members identified jumping as an evidence of spirit-baptism.

${ }^{58}$ The historian Jonathan R. Baer offered the strongest reading of the materiality of Pentecostal salvation. As he wrote, "Pentecostalism originated in the body as much as the spirit. ... Glossolalia and other ecstatic manifestations authenticated God's presence and power, reflecting the reality of the Holy Spirit within believers. But the materiality of the culture that gave rise to Pentecostalism received its fullest expression in 'divine healing.'" See Baer's "Redeemed Bodies: The Functions of Divine Healing in Incipient Pentecostalism," Church History, vol. 70, no. 4 (Dec, 2001), 735-771.

${ }_{59}$ Speaking in tongues bore physical proof of a spiritual reality. The word physical was deemed so important that when it was accidentally left out of the Assemblies of God "Statement of Fundamental Truths" in 1916, a special corrective was made a year later. See The Spirit and Spirituality: Essays in Honour of Russell P. Spittler, edited by Wonsuk Ma and Robert P. Menzies (New York: T\&T Clark International, 2004$), 224$. ${ }^{60}$ Douglas Gordon Jacobsen, Thinking in the Spirit: Theologies of the Early Pentecostal Movement (Bloomington, IN: Indiana University Press, 2003), 94-98.

${ }^{61}$ Wacker, Heaven Below, 25-28. Early Pentecostals transformed prayer into a divine contract. Yet subsequent generations exhibited a diversity of opinions on the uses of prayer. Prayer became, among other things, supplication, assurance, strength, and discipline.
} 
Nissi ("The Lord Our Banner of Protection.") In each name adherents found a key to personal power. The wide acceptance of Kenyon's The Wonderful Name of Jesus popularized the talismanic use of Jesus' name. In pulpits and prayer closets alike, believers intoned his name with a sweet reverence, expecting it to bring their petition, praise, or deliverance to completion.

\section{Health, Wealth, and the Rise of Black Metaphysical Religion}

Until now, this study has focused on white Protestant amalgamations of magical-religious practices and the topic of divine health. Yet in the first half of the twentieth century, gospels of health and wealth found a comfortable home within black Protestantism, a tradition commonly associated with social protest, civil rights, and stalwart congregations of Baptists and Methodists. What seemed to adherents like a new discovery, however, can be viewed as a historical recapitulation in African American Protestantism of persistent and pervasive Pentecostal and New Thought combinations. They produced prosperity gospels that not only set the stage for African American participation in the Faith movement, but also exemplified a continual theme: that mental magic provided Christians with an irresistible instrument of power.

In the early 1900s, Americans found metaphysical religion-and New Thought in particular-lurking everywhere, in Broadway plays, best-selling books, street-corner success manuals, and in the advice husbands heard from their wives when they looked up from Good Housekeeping. It had become the prevailing current of American popular religion, as difficult to identify as "religion" proper from the air people breathed. In 1901, William James observed the dawn of this era: “Mind-cure principles are beginning to so pervade the air that one catches their spirit at second hand." ${ }^{62}$ Though the institutional forms of New Thought remained dominated by whites, New Thought's

\footnotetext{
${ }^{62}$ James, The Varieties of Religious Experience, 93.
} 
widespread popularity guaranteed that all Americans, black and white, breathed it in. ${ }^{63}$

Many African Americans caught the spirit first hand. ${ }^{64}$ The late nineteenth century bore witness to the engagement of African Americans at all social levels with spiritualism, hypnosis, mesmerism, New Thought, and other variations of metaphysical religion. ${ }^{65}$ By the close of World War I, African Americans brought new forms of metaphysical religion to life. In the 1920s and 1930s, as the Great Migration pressed blacks into northern urban landscapes, a groundswell of alternative religious communities promised religious—and often metaphysical—answers to social and economic problems. Metaphysical gospels flourished in the urban north, as leaders like Sweet Daddy Grace, Prophet James Jones, Father Divine, Father George Hurley, and the Reverend Ike promised to smooth the rough edges of capitalism and industrialism with theologies that countered poverty, disease, and despair. ${ }^{66}$ These early prosperity gospels explicitly combined New Thought, Pentecostalism, and African-derived traditions (hoodoo, voodoo), a cross-pollination that resulted in black theologies that viewed the material world positively rather than with skepticism.

The rise of black Spiritualism, in particular, demonstrated the vitality and syncretism of metaphysical religion in urban African American communities. Nurtured in New Orleans and spread widely in the urban North and South in the 1920s and 1930s,

\footnotetext{
${ }^{63}$ Jill Watts, God, Harlem, U.S.A: The Father Divine Story (Berkeley: University of California Press, 1995), 22. Albanese, Republic of Mind, 472-478.

${ }_{64}$ The origins of New Thought in the African American community are difficult to pinpoint. While New Thought historian Beryl Satter argued for its significance within African American spirituality, she lamented that she was unable to recover its history because it operated in separate networks. Satter, Each Mind a Kingdom, 16.

${ }^{65}$ For more on the connection between New Thought and African American self help, see Beryl Satter's examination of W. E. B. Du Bois and race uplift manuals (Satter, Each Mind a Kingdom, 16) and Jill Watts's examination of New Thought's influence on the black self-help philosophies of Reconstruction (Watts, God, Harlem, U.S.A., The Father Divine Story (Berkeley: University of California Press, 1995); 22).

${ }_{66}^{6}$ For accounts of alternative black prosperity theologies, see Watts, God, Harlem, U.S.A; Jonathan L. Walton, Watch This! The Ethics and Aesthetics of Black Televangelism (New York: New York University Press, 2009), 47-74; Marie Dallam, Daddy Grace: A Celebrity Preacher and His House of Prayer (New York: New York University Press, 2007);Wilson Jeremiah Moses, "Chosen Peoples of the Metropolis." in African American Religious Thought: An Anthology, edited by Cornel West and Eddie S. Glaude Jr., (Louisville, Ky.:

Westminster John Knox Press, 2003); Clarence E. Hardy III, “' No Mystery God': Black Religions of the Flesh in Pre-War Urban America" Church History 77, no. 1 (2008): 128-50.
} 
black Spiritualism differed from the white Spiritualism popularized in 1848 by the Fox sisters' otherworldly communications. ${ }^{67}$ Black Spiritualism's fractious and experimental nature yielded a variety of expressions. In Detroit's Universal Hagar's Spiritual Church, Spiritualist Father George Hurley mixed Spiritualism with elements of Pentecostalism, Catholicism, voodoo, and black nationalism. In Chicago, the First Church of Deliverance might have been mistaken for a Pentecostal service but for its focus on séances, religious iconography, and channeling of the spirit world. ${ }^{68}$ The congregation swelled from a storefront to a 2,000-member body, known for its jubilant blend of Pentecostal worship, Catholic pageantry, and the invocation of magic. ${ }^{69}$ By the 1930 s, black Spiritualists had become the fastest growing religious communities among African Americans. ${ }^{70}$

African Americans adopted and adapted metaphysical religion, but more important, they applied it to the pressing questions of the day: scarcity, racism, segregation, and despair. Some black metaphysical gospels promoted individual solutions. Father George Hurley, for example, eschewed programmatic solutions for the urban black poor, urging his followers to counter racism with prayer and positive thinking. ${ }^{71}$ Others bent metaphysical ideals toward a communal gospel of self-help. Father Divine's Harlem-based Peace Mission protected poverty-stricken believers by providing clothing, food, housing, and job training. ${ }^{72}$ In Depression-era America, Father Divine famously fed thousands daily at his Peace Mission banquets, lavish meals that

\footnotetext{
${ }^{67}$ For a history of black spiritualism see Hans Baer and Merrill Singer, African-American Religion in the Twentieth Century: Varieties of Protest and Accommodation, $2^{\text {nd }}$ ed. (Knoxville: University of Tennessee Press, 2002), 183-215, and for a discussion of the interaction of New Thought with black Spiritualism see Darnise C. Martin, Beyond Christianity: African Americans in a New Thought Church (New York: New York University Press, 2005), 37-59.

${ }^{68}$ Wallace Best, Passionately Human, No Less Divine: Religion and Culture in Black Chicago, 1915-1952

(Princeton: Princeton University Press, 2005), 41.

69 See Walton, Watch This!, 69; Best, Passionately Human, 40-3; Hans A. Baer, The Black Spiritual Movement: A Religious Response to Racism (Knoxville: University of Tennessee Press, 1984), 26.

${ }_{70}$ Albanese, Republic of the Mind, 474.

${ }^{71}$ Hans A. Baer, "Universal Hagar's Spiritual Church." Encyclopedia of African and African-American Religions, ed. Stephen Glazier (New York: Routledge, 2001.).

${ }^{72}$ R. Marie Griffith, Born Again Bodies: Flesh and Spirit in American Christianity (Berkeley: University of California Press, 2004), 141; Watts, Father Divine, 106.
} 
defied segregation by seating black and white members beside one another. Elder "Lightfoot" Solomon Michaux, dubbed the "Happy Am I Preacher," preached Christian positive thinking to his radio audiences of more than two million, a message he bolstered with comprehensive social welfare programs. ${ }^{73}$ Black metaphysical Christianity entwined racial uplift with the power of the mind.

These self-help prophets proffered a symbolic materialism. Sweet Daddy Grace, founder of the United House of Prayer for All People, enjoyed a lavish lifestyle, replete with expensive cars, regal attire, and his trademark long hair and fingernails (testifying to his freedom from any form of manual labor). Prophet James F. Jones, famed radio evangelist and black Spiritual leader, gilded much of his worship facility, bestowed lordly titles on his congregation, and stuffed his mansion with expensive furnishings. He would be remembered by the Saturday Evening Post as the "Messiah in Mink." ${ }^{74}$ Father Clarence Cobbs of Chicago's First Church of Deliverance displayed a penchant for fashionable cars, lavish attire, and cigars. ${ }^{75}$ Yet beyond personal demonstrations of wealth, these leaders showed believers a path to personal fulfillment. These prosperity gospels promised a winning advantage within the framework of capitalism and industrialism. Father Divine diagnosed the cause (negative thinking) and the cure (positive thinking) for the Great Depression. Father Cobbs invested candles, flowers, or other objects with sacred power, asking participants for a monetary donation in exchange for the object (and the blessings it would bring).$^{76}$ Leaders offered prayers, rituals, and sacred objects to help believers bring about their desires. As the historian Jonathan Walton concluded, followers embraced a gospel that affirmed the material

\footnotetext{
${ }^{73}$ Hans A. Baer, "Elder Solomon Michaux's Church of God," in Encyclopedia of African and AfricanAmerican Religions, ed. Stephen Glazier (New York: Routledge, 2001), 122-123.

${ }^{74}$ Walton, Watch This!, 71.

${ }_{75}^{75}$ See Wallace Best, Passionately Human, 41; Walton, Watch This!, 69.

${ }^{76}$ See Baer, The Black Spiritual Movement, 26, and Harold A. Carter, The Prayer Tradition of Black People (Valley Forge, PA: Judson Press, 1976), 87.
} 
world: "The objects of human desires stemming from the cultural context of black people in cities-romance, financial success, physical healing, even a win from playing the numbers, are not shunned according to purist ideals but considered God-ordained blessings." 77 These uprooted city-dwellers knew what they wanted: a faith that closed the gap between desire and fulfillment.

In sum, the black prosperity gospels of the interwar period both introduced metaphysical religion to widespread African American audiences and asserted the importance of prosperity and religious access to the Good Life. The focus on material blessings, be it a mink or the next meal, established a precedent that later prosperity gospels were soon to follow. Their theologies reflected not only the black appropriation of predominately white metaphysical religion, but also the religious innovations of selfhelp prophets. It laid the groundwork for African American participation in the contemporary Faith movement at a deeper level. After World War II, when Pentecostals heralded the righteous acquisition of health and finances, African American followers accepted their vision of material salvation that echoed the black metaphysical religions of the interwar period.

These uplift movements throw Kenyon's gospel into stark relief. African American Pentecostalism resonated with metaphysical religion, a connection that proved to be electric. Pentecostalism provided a familiar narrative of sin, repentance, and salvation, sealed with Jesus' death and resurrection. New Thought, in contrast, persisted as a religion of utility. In other words, people found in it a religion they could use. The resulting messages combined a Christological framework with the mechanism of mental magic, guaranteeing believers the ability to change their circumstances by tapping

\footnotetext{
${ }^{77}$ Walton, Watch This!, 69.
} 
into new spiritual powers. ${ }^{78}$ Believers could expect their thoughts, emotions, actions, and happenstance to express God-given power and blessings. The fusion of New Thought and Pentecostal traditions produced a distinct strand of prosperity theology within African American religion, a livewire that pulsed with nothing short of magic.

\section{Gospels of Wealth}

Pentecostals, for the most part, had learned to do without. As the historian Grant Wacker documented, Pentecostals lived much the same lives as most Americans, as country-living, working-class folks with a grade-school education. ${ }^{79}$ Though they hailed from an economic cross-section of society, most earned a modest living working as laborers, craftsmen, service providers, and, sometimes, professionals, winning ordinary comforts and few excesses. From the patchwork tents of Pentecostal camp meetings to the pulpits of prominent leaders such as Charles Fox Parham, Smith Wigglesworth, and Aimee Semple McPherson, few believers projected economic ambitions through a theological lens. Though E. W. Kenyon promised heaven-sent finances, he spoke little of personal prosperity, resting on a shoestring budget to support his lifestyle and ministry. ${ }^{80}$ Holy Ghost people cried out for lost souls, healed bodies, miraculous tongues, and the Lord's kingdom to come, but rarely for material blessings that would change their social station. Even if Jesus himself had not recommended it, they might still have preferred to be salt of the earth.

Yet not all Americans smiled when fortune frowned. From roughly 1900 to 1950, many American Protestants, like the broader American culture, sought religious solutions to their economic troubles. Some wanted Christian sanction for what they already

\footnotetext{
${ }^{78}$ Catherine Bowler, "Positive Thinking," in The Encyclopedia of Religion in America, eds. Charles Lippy and Peter W. Williams (Washington: CQ Press, forthcoming 2010).

${ }^{79}$ Grant Wacker, Heaven Below, see especially chap. 12.

${ }^{80}$ Kenyon used finances as a testing ground for faith, but seldom as a measure. For example, Kenyon gave up his pastoral salary early in his ministry, depending on God for provision. This decision led to a break with his first congregation. Lie, E. W. Kenyon, 18, 22.
} 
owned, while others searched for tools to attain more. Many simply found a religious language of desire, longing coupled with the comfort that God ordered both the supernatural and mundane in their lives. While Pentecostals, Christian Scientists, and New Thought teachers, among others, called for faith, prayer, positive words, and surrender to divine health, a host of voices called for similar principles applied to economic use. These principles (later dubbed "positive thinking" after Norman Vincent Peale's landmark book, The Power of Positive Thinking, in 1952) endowed American Christianity with the same power that they granted divine health-the spiritual means to achieve results. ${ }^{81}$ Again, as with gospels of health, metaphysical religion supplied Christianity with the instrument required to close the gap between earnest faith and divine blessings.

The term "positive thinking" requires some explanation. Often mistaken simply for optimism, positive thinking stressed the power of the mind over matter. It leaned on monism and philosophical idealism to define how life rewarded those with right thinking. Positive thinking was synthetic, mixing the categories of religion, psychology, medicine, and self-help; its prophets were not typically systematizers or intellectuals, but popularizers and doers. By the 1950s, metaphysical religion, recast as positive thinking, earned a lasting place in the popular religious imagination and the American Faith movement.

Positive thinking found a comfortable home inside mainline Protestantism as both a reflection of its high view of human nature and potential, as well as an explanation for its middle-to-upper class respectability. Unlike positive thinking within holiness and radical evangelical traditions, mainline Protestants did not turn to the power of the mind for health. What they sought, nicely summarized by the title of

\footnotetext{
${ }^{81}$ Donald Meyer, Positive Thinkers, 259-289.
} 
industrialist Andrew Carnegie's famous essay, was a "Gospel of Wealth."

In the late nineteenth century, the Gilded Age's yawning gap between rich and poor prompted a flurry of Christian responses. Walter Rauschenbusch's Social Gospel and William and Catherine Booth's Salvation Army, to name only two examples, offered Christian solutions to the swelling ranks of the urban poor. Yet not all Christians sought to solve the problems inherited from industrialism and immigration. Some Protestants so identified Christianity with America's good fortune that they flocked to those who would explain the gospel as immanent to the fits and starts of capitalism. Russell H. Conwell (1843-1925), Baptist minister and lawyer, became a prophet of the Gospel of Wealth with his famous sermon, "Acres of Diamonds." The sermon, preached some 6,000 times, promised listeners that wealth lay within any American's grasp, if they would only accept their Christian duty to work hard and see God's hand through the workings of capitalism. Conwell re-interpreted his Calvinist inheritance for this new corporate age, equating poverty with sin and riches with dutiful virtue. "I say you ought to be rich; you have no right to be poor," he concluded sharply. ${ }^{82}$ Much like Horatio Alger's "rags to riches" dime novels, composed of anecdotes of virtue rewarded by financial windfalls, Conwell paired theological and fiscal optimism, resting on a high view of human perfectibility. Conwell's Wall Street gospel agreed with the unfettered accumulation by the nation's first millionaires and billionaires, sharing the mythical secret that brought an Andrew Carnegie or John D. Rockefeller to the top: sheer will. ${ }^{83}$

\footnotetext{
${ }^{82}$ Russell H. Conwell, Acres of Diamonds (Philadelphia: Temple University Press, 2002), 22. Conwell tempered his stress on accumulated wealth by instructing those of good fortune to be generous stewards. See William R. Hutchison, Religious Pluralism in America: The Contentious History of a Founding Ideal (New Haven, CT: Yale University Press, 2003), 93-100.

${ }^{83}$ For more on religious interpretations of wealth, see Conrad Cherry, God's New Israel: Religious Interp retations of American Destiny (Chapel Hill: University of North Carolina Press, reissued 1998, original 1971), prologue to Part V and 249-59.
} 


\section{Metaphysical Money}

For many Americans, however, sheer will was not enough. A little divine assistance might be needed. New Thought began as a prescription for mental and physical wellbeing. Yet New Thought's early focus on health did not last long, for by 1890, New Thought had expanded its vision of what mystical alignment with the divine could bring. It was not simply that the movement's growth and newfound institutional strength that fortified the boldness of its convictions. New Thought leaders, as the historian Beryl Satter documented, adopted a new (and contested) focus on desire, prosperity, and materiality. ${ }^{84}$ The turn proved permanent. Unity with God, many speculated, could merit both health and material abundance. This strand of metaphysical religion tilted toward knowledge, thought, and "the powers of mind, in individualistic terms, to heal disease, achieve prosperity, and enjoy personal success." 85 Teachers like Frances Lord made prosperity a centerpiece of New Thought, following in the footsteps of Emma Curtis Hopkins (1853-1925), her teacher, who quietly included material abundance as one of the many manifestations of right thinking. ${ }^{86}$ Helen Wilmans (1831-1907) penned The Conquest of Poverty (1899), one the first examples of prosperity themes within New Thought. Charles (1854-1948) and Myrtle (1845-1931) Fillmore, founders of the influential Unity School of Christianity, found prosperity to be integral to New Thought. Charles Fillmore's aptly titled book Prosperity (1936) spoke of a God that Russell Conwell would have recognized-a God of abundant supply. Yet, unlike Conwell, Fillmore's road to success lay within. Teaching that God was the divine Supply, he implored listeners to align themselves with this divine Source. This spiritual

\footnotetext{
${ }^{84}$ Satter dissected the notion that New Thought was solely as an economic message, but my study focuses on this single (though not totalizing) characteristic.

${ }^{85}$ Catherine Albanese, America: Religion and Religions (Belmont, CA: Wadsworth, 1992), 271.

${ }^{86}$ Gail M. Harley, Emma Curtis Hopkins: Forgotten Founder of New Thought (Syracuse, NY: Syracuse University Press, 2002), 71-74; Albanese, A Republic of Mind, 320.
} 
mutuality would yield financial and spiritual blessings.

Older themes in New Thought faded as metaphysicians like Ralph Waldo Trine (1866-1958) trumpeted the movement's new values. Early New Thought, as Albanese argued, centered on themes of correspondence and the mind: language that evoked images of balance and mental stasis. As New Thought moved into the twentieth century, confidence in the power of the mind-and its corresponding ability to access divine sources-ruptured any concept of the mind as static. Metaphors shifted to "energy," "flows," and "streams" as believers asserted the instrumentality of thought. ${ }^{87}$ Trine, whose metaphysical inheritance from Ralph Waldo Emerson was stamped even on his name, popularized these emergent themes with his bestseller In Tune with the Infinite (1897). With two million copies sold by Trine's death in 1958, he became a leader among metaphysical teachers. He implored readers to see themselves as channels of divine energy and learn to be ready vessels for divine flow. Stagnant emotions and thoughts blocked healthy transmission, leading to misery and disease. Right thinking would open the floodgates to the abundant life: "See yourself in a prosperous condition. Affirm that you will before long be in a prosperous condition. ... You thus make yourself a magnet to attract the things that you desire." ${ }^{88}$

Trine's focus, method, and readership became hallmarks of the New Thought genre and, later, the Faith movement. First, Trine's focus never strayed from the theme of self-actualization. In other words, though he addressed other topics, he always majored in inspiration. Like countless authors after him, he insisted that any person could spiritually align him/herself with happiness, health, and fortune. In trumpeting human potential, he evoked readers' desire that spiritual forces could reach into the material world and right any wrongs. Second, his method prized accessibility and popular

\footnotetext{
87 Albanese, A Republic of Mind, 394-399.

${ }^{88}$ Simmons, E. W. Kenyon, 216.
} 
appeal. Unlike many of New Thought's earliest prophets, Trine eschewed theological precision in favor of usefulness. Rather than descriptive, Trine's work remained prescriptive. He meant it to be followed, not simply read. Third, Trine left a lasting impression. As the author of the first New Thought bestseller, Trine made the so-called everyman his target audience. Trine charted a path to prosperity that appeared compatible with his largely Christian readership, careful to choose Christian language and concepts that would not wrinkle the noses of the Protestant mainstream. New Thought literature followed him, becoming increasingly targeted toward religious nonspecialists, and even nonbelievers. Sweeping generalities buried the specifics, allowing New Thought to move beyond its sectarian heritage and into a blurry-but powerfulcollection of religious beliefs inextricable from American culture itself.

\section{The "Disappearance" of New Thought}

In the first decades of the twentieth century, New Thought ruled a kingdom of ink as its prophets penned innumerable books designed for mass appeal. Theologically thin but thick with guarantees of success, these self-assurance manuals sought availability over respectability. Critics found the publications crude and insincere, as their cheap and often poorly produced manuals papered the city. Yet their broad appeal won them continued relevance.

New Thought's gospel of success evolved into a steady stream of success literature, which crisscrossed among the genres of self-help, business, and metaphysical religion. Success literature found wide readership. ${ }^{89}$ By 1905, Orison Swett Marden's Success Magazine, boasting a circulation of 300,000, promised just that, success in all

\footnotetext{
${ }^{89}$ Critics often depicted New Thought as a garish "cult of success." Whitney Griswold, "New Thought: A Cult of Success," American Journal of Sociology 40 (November 1934): 309-18. See also Richard Weiss, The American Myth of Success: From Horatio Alger to Norman Vincent Peale (Urbana: University of Illinois Press, [1969] 1988); Donald Meyer, The Positive Thinkers: Religion as Psychology from Mary Baker Eddy to Oral Roberts (New York: Pantheon Books, [1965], 1980).
} 
aspects of life. ${ }^{90}$ William Walker Atkinson (known also as Swami Ramacharaka) became one of the most popular authors of New Thought success literature. His many works, including The Secret of Success (1908), Mind-Power (1908), and The Secret of Mental Magic (1912), popularized New Thought's interest in the power of the mind and its instrumental value. He taught that the conscious mind controlled the unconscious, unlocking the "secret" to attaining what one desired. This high emphasis on mental magic put prosperity under the mind's control. The Unity School of Christianity, the largest of New Thought's denominations, published The Christian Business Man (1922) in an effort to show readers how to apply New Thought principles to the marketplace. ${ }^{91}$ Kenyon's own Sign Posts on the Road to Success (1938) joined the trend.

New Thought's boundaries blurred further as its authors appropriated psychological language with increasing boldness. ${ }^{92}$ New Thought pioneer William Atkinson, for instance, showed only glimmers of psychological familiarity at the dawn of the twentieth century. By 1910, Atkinson's Your Mind and How to Use It: A Manual of Practical Psychology equated New Thought with the burgeoning field of mental health. ${ }^{93}$ Frank Haddock, author of the bestselling The Power of the Will (1907), similarly offered New Thought ideas in a psychological form. Haddock repackaged New Thought as an instruction manual for success replete with drills. Without religious references, he taught

\footnotetext{
${ }^{90}$ Satter, Each Mind, 226.

${ }^{91}$ Simmons, E. W. Kenyon, 216. The organization The Full Gospel Business Men did much the same for charismatic Christianity a half-century later.

${ }^{92}$ Satter, Each Mind, 239. New Thought's mental sciences were not alone. Beginning in the 1870s, European neuroscientists began to seek out the causes of mental illness. Their investigations coalesced into the field of psychology, devoted to applying scientific inquiry to the workings of the mind. By the 1880s, psychology had begun to take shape as an American academic discipline. These pioneers developed experiments of their own, and institutional support for their work began to solidify. Laboratories for psychological experiments opened in the University of Pennsylvania (1887), Indiana University (1888), and the University of Nebraska (1889), to name a few. The newly formed American Journal of Psychology (1887) and the Psychological Review (1894), along with the founding of the American Psychological Association (1893) gave the fledgling field legitimacy and scholarly reach.

Satter, Each Mind a Kingdom, 239.
} 
readers to activate the will and teach it to succeed. ${ }^{94}$ The distinction between psychology and religion was equally confused in popular discourse. Fashionable magazines used New Thought and psychological authorities interchangeably, "present[ing] physicians, Protestant ministers, early psychotherapists, and New Thought healers as equally valid schools of modern psychotherapy." ${ }^{95}$ This hybrid identity-part metaphysical, part psychological, and part success literature-formed the foundation of "self-help." 96 New Thought's influence did not weigh heavily on American culture in its institutional form, but endured because of its confluence with like-minded ideas. ${ }^{97}$ With Horatio Dresser writing for Good Housekeeping, Trine for Woman's Home Companion, and similar themes enacted through popular novels and plays, New Thought's sectarian differences softened into palatable generalities. ${ }^{98}$ As Albanese observed, this may not have been entirely accidental. "It disappeared," wrote Albanese. "It became a part of general culture, so that by effacing its own logo it successfully shaped American mentality in marked and continuing ways." ${ }^{99}$ After World War II, it would resurface in the American religious imagination as "positive thinking," equal parts psychology, business, self-help, and metaphysics. In erasing its particularities, New Thought marketed a message that articulated and spiritualized American self-perceptions. New Thought uncovered the hidden truth that Americans longed to hear-that divinity was lodged somewhere in their beings, and that their secret powers demanded expression. It

\footnotetext{
${ }_{94}^{94}$ Meyer, The Positive Thinkers, 164-167.

${ }^{95}$ Satter, Each Mind a Kingdom, 240.

${ }^{96}$ For the intersection of popular psychology and New Thought at the turn of the twentieth century, see Satter, Each Mind a Kingdom, 239-247.

${ }^{97}$ New Thought by no means dissolved, however. A series of small but sturdy sects-Divine Science Federation International, Religious Science, and the Unity School of Christianity - continued into the twentyfirst century.

${ }^{98}$ Satter, Each Mind a Kingdom, 226. For a contemporary study of this diffuse influence, see Michael F. Brown, The Channeling Zone: American Spirituality in an Anxious Age (Cambridge, MA: Harvard University Press, 1997).

Albanese, A Republic of Mind, 436.
} 
represented a powerful combination of two spiritual conclusions, "inner divinity," and “outer power." 100

\section{Corporate Metaphysics}

The Gospel of Wealth continued to ride the wave of prosperity through the 1920s. As Americans transitioned from the World War I wartime economy to a peacetime order, a flood of new wealth rewarded big business and avid consumerism. The economic leader was lionized; as Brooks Holifield argued, "the First World Warand the economic boom that followed-elevated the manager of massive organizations and the successful businessman to even greater cultural authority." ${ }^{101}$ Theologically, too, economic themes took precedent. American Christians' valorization of manly virtue, epitomized by the Muscular Christianity of evangelist Billy Sunday, took on a decidedly corporate cast. Jesus himself possessed business acumen, as Bruce Barton's The Man Nobody Knows (1924) revealed him to be "an extraordinarily successful executive who forged an organization that 'conquered the world' by the use of modern business methods." ${ }^{102}$ As the church modeled big business, lay people turned to a gospel that explained how wealth, capitalism, and devotion coincided.

Soon the economic collapse of the Great Depression tested the Gospel of Wealth's mettle. Yet while the financial hardships of the American public seemingly severed its love affair with capitalism, new voices arose to defend the virtuous acquisition of wealth. Its champions included Dale Carnegie (1888-1955). Carnegie sold a solution that an impoverished population could afford-positive thinking. He

\footnotetext{
100 Ibid.

101 Brooks Holifield, God's Ambassadors: A History of the Christian Clergy in America (Grand Rapids: Eerdmans, 2007), 160.

${ }^{102}$ Ruth Miller Elson's Myths and Mores in American Best Sellers, 1865-1965 (New York: Garland, 1985), 186. That is not to say, however, that Bruce Barton and Charles Sheldon (author of the bestselling In His Steps) dismissed social problems with trite individualism. Like the advocates of the Social Gospel, these authors urged Christians to remake sinful institutions by taking the hard road through personal sacrifice. See Hutchison, Religious Pluralism, 100.
} 
popularized the relationship between thought and wealth acquisition with his bestselling How to Win Friends and Influence People (1936). Through radio, print media, and his "Dale Carnegie Course," Carnegie guaranteed a secularized demonstration of the power of positive thinking. His folksy principles, such as "Smile" or "Be a good listener," became one of the first self-help bestsellers and carved out a place for the power of the mind within a supposedly secular, though overwhelmingly Protestant, sphere. A year after Dale Carnegie taught the American public how to win friends, Napoleon Hill published Think and Grow Rich, a New Thought rendering of similar goals. Hill promised to reveal the secret of Andrew Carnegie's success, allowing any person to achieve the good life. Several techniques proved effective, Hill argued. Visualization would unleash the mind's power for the imagined object: "Hold your thoughts . . on money by concentration, or fixation of attention, with your eyes closed, until you can actually see the physical appearance of the money. Do this at least once each day." ${ }^{103}$ Repetition was also key. Hill urged practitioners to repeat instructions to the unconscious mind, which was "the only known method of voluntary development of the emotion of faith." 104 The mind was energy, and required visualization and affirmations to be released. Divine Science author Emmet Fox also assured the masses that resources were only a thought away, as his bestsellers The Sermon on the Mount and Power Through Constructive Thinking reasserted the reality of divine supply. ${ }^{105}$

Though the American economy failed to provide prosperity, it continued to shape Depression-era Protestant thinking. In an exhaustive study by the Yale psychologist Mark A. May and the Union Seminary theologian William Adams Brown, published as The Education of American Ministers, May and Brown fretted, "'The modern

\footnotetext{
${ }^{103}$ Meyer, The Positive Thinkers, 170.

104 Albanese, A Republic of Mind, 441.

105 Satter, Each Mind a Kingdom, 251.
} 
psychology of business success' guided lay expectations of ministers. The churches wanted 'a winner, not only of souls, but of dollars and prestige.' "106 Parishioners desired spiritual leadership to succeed where the economy had not, producing financial success in spite the hard times. Self-help literature obsessed with "business virtue" cluttered the shelves, as the stolid world of business demanded constant introspection. Why did one investor succeed while another failed? Surely market timing, personal connections, or a sixth sense for business answered that question. The newly minted self-help genre turned to "character" to explain capitalism's unruly favor. The virtuous businessman would succeed where others had failed. As Donald Meyer argued, character became the enduring focus, qualities which mixed and matched religious ideals and practical values. It was the Protestant work ethic restored, which "supplement[ed] the standard 'religious' virtues of faith, hope, charity, etc., with the 'secular' virtues of industry, thrift, honesty, practicality, rationality, and the like." ${ }^{107}$ As the economic rollercoaster of the 1920s and 1930s brought Americans high and then low, commerce and Christianity remained separated because believers read their own religious fortunes by the changing times.

\section{Twice Blessed: The Gospel of Health and Wealth}

Post-World War II America considered itself doubly blessed. The economy boomed, sustaining the nation's largest middle-class in history. Good health required fewer miracles, as medical advances staved off previously deadly illness with mass vaccines for polio and tuberculosis. Positive thinking matched the nation's triumphant mood, trumpeting the spiritual activism, high anthropology, and confidence in the mind that resonated through American culture. Even Pentecostals found the message

\footnotetext{
${ }_{107}^{106}$ Holifield, God's Ambassadors, 219.

107 Meyer, The Positive Thinkers, 129.
} 
irresistible. In the 1940s and 1950s, independent Pentecostal healing evangelists began to speak of financial blessings, spiritual laws, and the significance of high-spirited faith.

As the product of post-World War II Pentecostal healing revivals, one might have expected the prosperity gospel to remain a message by and for Full Gospel (which is to say, historically Pentecostal or Pentecostal-like) believers. Yet its construction from multiple religious elements built up its wide appeal across racial and denominational lines. In its myriad forms, as success literature, popular psychology, faith cure, mind cure, positive thinking, or African American uplift gospels, this genus of mental magic provided Christians with a supplemental set of tools to solve problems. How can I overcome pain with prayer? How can I provide for my family? What must a believer endure? Christianity, infused with mental magic, allowed sufferers greater access to God. Divine principles granted every person admission to God's tender mercies. The emphasis on practice was irrepressible. Truths were "techniques," waiting to be "applied." Self-esteem, health, finances, or divine power itself became transferable, goods requiring safe passage from God to the believer, or one believer to another. Whether through prayer, hypnotism, the use of placebos, or the power of suggestion, believers cultivated religious practices and techniques to subdue, focus, or activate its hidden powers. This new type of thinking amplified Christian notions of spiritual power, remaking the gospel into a forceful tool for achieving health and wealth.

As the Faith movement dawned, Essek William Kenyon was living in his twilight years. The grandfather of the modern Faith message, he died in 1948, the first year of the post-World War II healing revivals that gave national attention to the incipient prosperity gospel. The postwar generation that rediscovered Kenyon's “overcoming faith" heard it echoed in diversely constituted gospels of health and wealth that resounded in American culture. The African American uplift movements that ruled the metropolis found new Christian audiences through the controversial icon, Reverend Ike. 
Secular and mainline "positive thinking" reappeared in magazines and television as the self-help messages of Norman Vincent Peale. As the Faith movement coalesced in the postwar years, independent Pentecostal revivalists immersed their old-time gospel in the same certainty, nurturing an understanding of faith characterized by unyielding confidence. Kenyon's gospel became the primary Christian vehicle of mental magic, a refinement of the mechanism by which the believer's authority and God's power met. His message soon rang out in the testimonies, revelations, and prophecies of a like-minded generation of true believers. 


\section{Chapter Two: Faith}

"Once you become a Christian, then the most important thing for you to learn is the law or principle of Faith. There is nothing else in the kingdom of God more important than F-A-I-T-H. Nothing is more important. You can't THINK of anything more important. You can't find anything in the Word of God that's more important than Faith."

Frederick Price, speaking at the Azusa Street Centennial, Los Angeles, April 26, 2006

Frederick Price comfortably leaned his weight on his own pulpit, surveying the thousands gathered in his Faith Dome. In 2006, a hundred years after the fits and starts of Pentecostalism first marked Azusa Street, a sprawling church complex a few miles from the original site gathered its respectable commemorators for the Azusa Street Centennial. Price enjoyed a home-court advantage, as Pentecostal and charismatic Christians from across the country descended into distinctly Faith territory on this second night of the Azusa Centennial. Not all who came expected to like what they heard, as Pentecostal and charismatic attendees held conflicting theological opinions about prosperity teachings. Betty Price, wife and co-pastor, and Frederick Price Jr., his brawny soon-to-be successor, sat in the front row beside other prosperity celebrities. They would hear Price attempt to win the crowd to Faith and to distinguish its teaching from "traditional" Christian messages. Price described his assignment for the evening as a reminder, though for some, he said, this would be a revelation. His crisp sentences bore no mediations and no apologies. Price promised to outline the meaning of Faith, a subject often misunderstood, in the simplest terms. Principally, "Faith is a law. A spiritual law," he declared. With that, Price laid the foundation on which all Faith messages must rest.

\footnotetext{
${ }^{1}$ Frederick Price, Azusa Street Centennial General Sessions (CD), (Divide, CO: Kingdom Recordings, 2006).
} 
The Faith movement, as the name suggests, marched under the banner of Faith, now defined as the power to actualize reality. Many of its largest churches reaffirmed this commitment in their choice of names. Keith Butler's Word of Faith International Christian Center in Detroit, Dale Bronner's Word of Faith Family Worship Center in Atlanta, Casey Treat's Christian Faith Center in Seattle, and Faith World, Benny Hinn's former church in Orlando, stood as a few examples. When Dr. Frederick Price's Ever Increasing Faith ministry built a facility to seat more than 10,000, the largest worship center at the time of its completion in 1989, Price named it the Faith Dome. Faith became the topic on which every teacher cut their teeth, and rivaled even health and wealth as the subject of popular publications.

This chapter shows how Faith teaching took root in the healing revivals of the late 1940s and 1950s in the form of a jumbled and results-driven cluster of ideas represented by Kenneth Hagin, A. A. Allen, T. L. Osborn, Thomas Wyatt, and Oral Roberts. By the end of the 1970s, it grew into a discernable movement—-the Faith movement-marked by theological and institutional strength. Two main factors contributed to the movement's extraordinary growth. First, prosperity theologies nurtured outside the bounds of the Pentecostal revivals intersected with the Faith movement as similar renderings of the power of faith to produce results. Middle-class American society celebrated it as positive thinking; likewise, it developed among African Americans as a gospel of economic uplift. Second, as the mid-century Pentecostal revivals gave way to what became known as the charismatic movement (circa 1958-1974) that spread Holy Ghost fervor throughout mainline Protestant and eventually Roman Catholic congregations, its proponents tamed the raucous temperament of postwar revivalism to suit new, affluent 
audiences. ${ }^{2}$ As a result, the Faith movement took on greater refinement and uniformity. Its leading lights, including fresh faces like John Osteen, Morris Cerullo, Kenneth Copeland, Frederick Price, and Rex Humbard, traded tents for churches, itinerancy for institutions, and most notably, healing for prosperity. During this period of transformation from a mid-century healing gospel, through positive thinking, to the charismatic revival, we can see how the prosperity movement distinguished itself primarily in its instrumental understanding of Faith.

\section{Healing Faith, 1947-1958}

In 1950, Kenneth E. Hagin, the acknowledged "father" of the Faith movement, declared the law of Faith. ${ }^{3}$ Though Hagin credited his 1934 recovery from heart trouble as the moment when he discovered the inner workings of Faith, almost two decades passed before he heard God's instructions to "Go teach My people faith!" through radio and publication. Hagin's message-which recapitulated E. W. Kenyon's earlier workintroduced Pentecostals to a bold explanation for how God and the believer's piety worked in tandem. To be sure, most mid-century healing evangelists assured listeners that God abundantly blessed the faithful. Pentecostals enjoyed the postwar economic boom as contented middle-class citizens, and proved as keen as any American to believe God might have something to do with it. Yet as teachers began to introduce finances, alongside healing, as a spiritual gift, Hagin provided a compelling vision of how God transformed faith into favor. He called it the law of Faith. ${ }^{4}$

\footnotetext{
${ }^{2}$ Traditional or classical Pentecostalism helped give birth to the charismatic movement, but the two never completely overlapped. Scholars distinguished the latter by its a) mainline denominational roots, b) postWorld War II origins c) emphasis on spiritual gifts rather than tongues, and d) slightly higher class location. See David Edwin Harrell Jr., All Things Are Possible: The Healing and Charismatic Revivals in Modern America (Bloomington, IN: Indiana University Press, 1975), 135-149.

${ }^{3}$ Kenneth Hagin Jr., "Trend Tow ard Faith Movement," Charisma, August 1985, 67-70.

${ }^{4}$ Faith teachers drew the term from Romans 3:27 (KJV): “Where is boasting then? It is excluded. By what law? of works? Nay: but by the law of faith." For a detailed example of this exegesis, see Creflo Dollar, The Color of Love: Understanding God's Answer to Racism, Separation, and Division (Tulsa: Harrison House, 1997), 2335.
} 
The law of Faith bound God's Word into judicial guarantees. As Hagin's theological predecessor E. W. Kenyon had explained, "Christianity is a legal document," in which believers find rights to salvation, protection, and victory over all circumstances. ${ }^{5}$ Jesus' death secured these rights for humanity from Satan, and transferred God's "power of attorney" to believers, who became entitled to use God's power as their own. ${ }^{6}$ These legal benefits afforded followers (to use one of the movement's well-worn phrases) "rights and privileges": the safety, health, happiness, and financial security promised to each Christian. In crusades, televised sermons, writein testimonials, and casual conversation, participants spoke of rights and privileges as shorthand for the abundant blessings believers could command "in Jesus' name." Conversely, those who did not demonstrate God's power-plagued by doubt, poverty, or disease-fell to live "beneath their privileges." ${ }^{7}$ The law of Faith itself acted as the contract to secure these Christian liberties, in Kenyon's words, providing "the warranty deed for that the thing for which you have fondly hoped is at last yours." 8

Kenneth Hagin had picked a propitious moment for pronouncing his law of Faith. After World War II, hundreds of ministers broke from their Pentecostal denominations to form independent evangelistic associations, ministries whose lifeblood was the bold examples and promises of their charismatic founders. Most of these ministers were faith healers at heart, as the periodical titles of Oral Roberts's Healing Waters (1947), Gordon Lindsay's Voice of Healing (1948), and Jack Coe's Herald of Healing (1950) attest. Across America, rank-and-file Pentecostals gathered under the canvas to hear the principal

\footnotetext{
${ }^{5}$ E. W. Kenyon, The Father and His Family (Lynnwood, WA: Kenyon's Gospel Publishing Society, 1998$), 191$.

${ }^{6}$ E. W. Kenyon, The Wonderful Name of Jesus (Lynnwood, WA: Kenyon's Gospel Publishing Society, 1998$), 4$.

${ }^{7}$ For an example of the prevalence of legal language in Faith theology, see Milmon Harrison, Righteous

Riches: The Word of Faith Movement in Contemporary African American Culture (New York: Oxford

University Press, 2005), 8-10. For an example of condemnation for those living "beneath our privileges," see Kenneth E. Hagin, "Is Your Profit Showing?" Word of Faith, January 1976, 4-5.

${ }^{8}$ E. W. Kenyon, The Two Kinds of Faith: Faith's Secret Revealed, 17 ${ }^{\text {th }}$ ed. (Lynnwood, WA: Kenyon's Gospel Publishing Society, 1998), 7.
} 
themes of this revival: healing, prophecy, cooperation, and evangelism. ${ }^{9}$ Yet the heartbeat of each service, observed David Harrell, "was the miracle-the hypnotic moment when the Spirit moved to heal the sick and raise the dead." ${ }^{10}$ Successful ministers guaranteed the miraculous, commanding spiritual forces with ease. The revivalist O. L. Jaggers, author of Everlasting Spiritual and Physical Health, touted the spirit-filled minister as a divine powerhouse, who "will do VERY LITTLE PRAYING FOR THE SICK . . . HE WILL GIVE COMMANDS THAT THE SICKNESS LEAVE."11 A hunger for new miracles-beyond the mundane paralytic walking, blind seeing, and deaf hearing—cultivated an atmosphere of supra-supernaturalism, startling claims that shocked crowds and strained credulity. ${ }^{12}$ In 1956, the Miracle Magazine founder A. A. Allen claimed that "miracle oil" streamed from revival participants' heads and hands, and, on a separate occasion, a photograph of his revival showed demonic and divine forces doing battle. ${ }^{13}$ Cover stories like "I Took My Cancer to Church in a Jar" chronicled a pastor healed by A. A. Allen who returned to the revival the following night with bottled proof. ${ }^{14}$ The gifted but controversial Franklin Hall penned recipes for miraculous power including Atomic Power with God Though Prayer and Fasting (1946) and Formula For Raising the Dead (1960). He promoted "Bodyfelt Salvation" as a potent healing substance that warded off emotional distress as well body odor, a teaching he demonstrated by refusing to wash his own jacket, worn to all crusades, as it was already without "spots or odors." ${ }^{15}$ In 1956, the Assemblies of God took aim at the raucous supernaturalism of healing evangelism, repudiating, among other things, the

\footnotetext{
${ }^{9}$ Harrell, All Things Are Possible, chap. 5.

${ }^{10}$ Harrell, All Things Are Possible, 6.

11 O. L. Jaggers, Everlasting Physical and Spiritual Health (Dexter, MO: Kessinger Publishing, 1949), 100-110.

${ }^{12}$ By the mid-1950s, these assertions divided the healing revival. See Harrell, All Things Are Possible, 89.

${ }^{13}$ Ibid.

${ }^{14}$ The participant returned with "six cancers in a jar which he had passed since his healing the night before." Miracle Magazine, January 1960, 1, 7.

${ }^{15}$ Unknown author, “Coat Never Needed Cleaning," Miracle Word, Fall 1975, vol. 10, no. 4, 22.
} 
alleged scriptural foundation for public diagnosis of illness and (likely with Allen's claims in mind) any miraculous "exuding of oil or appearance of blood."16

Kenneth Hagin stood apart from his miracle-working contemporaries by his acute analysis of the means by which spiritual power transformed into material results. Faith, according to Hagin, acted as a causal agent, a power that actualized events and objects in the real world. Faith corresponded to natural forces that, like gravity and electricity, were invisible operators of cause and effect. ${ }^{17}$ This Faith-force subjected the natural world to its power regardless of human opinion or assent, existing as a force apart from but available to humanity. The radio and healing evangelist Thomas Wyatt concurred: "If we will use faith as an operating force, we can control the physical realm, for faith operates on the basis of spiritual laws which are effective in the physical realm. ${ }^{18}$ Faith was seen as a law, and as such it operated as a universal and uniform reality; there need not be a leap of faith, as Faith would prove itself. The Oklahoma healer Tommy L. Osborn, borrowing directly from E. W. Kenyon, agreed: "Faith brings the unseen things into being and makes the unfelt things real to the senses." ${ }^{19}$ Throughout the 1950s, Hagin's understanding of this phenomenon did not win widespread agreement or interest among Pentecostal ministers. Hagin spent the turbulent decade beating the evangelistic circuit as an Assemblies of God preacher, a local attraction rather than a major campaigner. Most of his cohort seemed to be content merely with the results of their wonder-working power.

\footnotetext{
${ }^{16}$ Harrell, All Things Are Possible, 108-109.

17 John G. Lake, The John G. Lake Sermons on Dominion over Demons, Disease, and Death (Dallas: Christ for the Nations, 1982), 56. The growing authority of science likely prompted Christians to take up scientific language to describe the operation of spiritual power. Amanda Porterfield, Healing in the History of Christianity (New York: Oxford University Press, 2005), 159. As the sociologist Mark Chaves argued, the rise of scientific authority circumscribed religious authority, but did not snuff it out. Mark Chaves, "Secularization as Declining Religious Authority," Social Forces 72(3), 749-74.

${ }^{18}$ Basil Miller, Grappling With Destiny (Los Angeles: Wings of Healing, 1962), 100 for "divine principle" and 134-135 for "spiritual laws."

${ }_{19}$ T. L. Osborn, Healing the Sick, 1992 ed. (Oklahoma City: T. L. Osborn Evangelistic Association, 1951-92), 83-84. For Osborn's reliance on E. W. Kenyon, see Dale H. Simmons, E. W. Kenyon and the Postbellum Pursuit of Peace, Power, and Plenty (Lanham, MD: The Scarecrow Press, 1997), 296-298.
} 
The Tulsa evangelist Granville Oral Roberts proved to be a major architect of the Faith message, towering over the healing revivals of the 1940s and 1950s as a man of faith. He lacked the preternatural healing power of William Branham, whose prophecy and angelic visitations whetted Pentecostals' thirst for new signs and wonders. Neither did he, like Gordon Lindsay, the revival's lauded publicist, rally diverse ministers behind the common cause. Rather, he eclipsed other ministers because of his shrewd ability to anticipate the new frontiers for ministry in radio, television, and education. This Midas touch provided innumerable demonstrations of the blessings of faith, and, like Hagin, he developed his own vocabulary to account for it. His influential catchphrase summed up his triumphant theology: "God is Greater," “Turn Your Faith Loose," and "Something Good is Going to Happen to You." ${ }^{20}$ Oral Roberts's cheerful reminder to "Expect a Miracle" reconciled two opposing poles—predictability and otherworldliness-that Hagin codified in his law of Faith. Faith would cause the supernatural to bend miracles to the will of everyday believers.

Roberts's miraculous recovery from tuberculosis and stuttering sent him headlong into his ministerial vocation. Then, in 1947, Roberts uncovered a biblical imperative to prosper tucked into 3 John 2: “Beloved, I wish above all things that thou mayest prosper and be in health even as they soul prospereth." His 1952 autobiography (the first of many) described it as "the greatest discovery I ever made" and the foundation on which his sprawling ministry stood. ${ }^{21}$ His radio program, Healing Waters magazine, and first book, If You Need Healing - Do These Things!, soon followed. By the mid-1950s, his mushrooming ministry and prosperity theology developed hand-in-hand, as his magazine, radio, and then television audiences grew exponentially. His 1954

\footnotetext{
${ }^{20}$ David Edwin Harrell Jr., Oral Roberts: An American Life (Bloomington: Indiana University Press, 1985), 152.

${ }^{21}$ Oral Roberts, Oral Roberts' Life Story: As Told by Himself (Tulsa: Oral Roberts Ministry, 1952), 70-75. 
introduction of the "Blessing Pact" promised that God would repay contributors for their donation to Oral Roberts's ministries "in its entirety from a totally unexpected source." The same year he offered his first calculus of spiritual returns, predicting a seven-fold return for donors. His publication God's Formula For Success and Prosperity (1956) offered believers a systematic approach to divine blessings, though it stopped short of Hagin's immutable laws. In 1970 Roberts coined the term "seed faith," an idiom that infused the present with potential and purpose. Faith teachers subsequently dubbed each prayer, tithe, word, emotion, or action a "seed" whose spiritual consequences—-good or bad-had not come into season. In many respects, Roberts and Hagin preached parallel prosperity gospels; though both linked prosperity to faith, each saw it in different terms. ${ }^{22}$ The former saw Faith as a promissory note with a likely return, while the latter envisioned Faith as a package, signed and delivered.

Viewed from afar, we can see aspects of the greater healing revival that formed the rough contours of Faith theology. The Faith gospel's financial message echoed in many quarters. Ministers such as A. A. Allen and Thomas Wyatt doggedly promoted prosperity, alongside their stock message of healing, paving the way for the prosperity gospel's widespread acceptance in the 1960s. A. A. Allen, known for his healing campaigns, Allen Revival Hour radio broadcast, and his ability to cause a stir, became one of the first revivalists to herald veritable financial miracles. His timeworn story of the transformation of his one-dollar bills into twenties assured listeners: "I believe I can command God to perform a miracle for you financially. When you do, God can turn dollar bills into twenties." ${ }^{23}$ Likewise, Wyatt founded Wings of Healing ministries with a divine imperative to preach faith for human prosperity. ${ }^{24}$ He taught, like Hagin, that

\footnotetext{
22 The two first crossed paths in 1948 when Hagin attended Roberts's Dallas crusade. Harrell, Oral Roberts, 152.

${ }^{23}$ Harrell, All Things Are Possible, 75.

${ }^{24}$ Miller, Grappling with Destiny, 82.
} 
Christians enjoyed direct access to God's creative power and the resulting ability to control the material realm. ${ }^{25}$ Yet despite his triumphant message, Wyatt did not apply this rigorous faith to all aspects of his life and ministry. A rough-and-tumble preacher known for building his own ministries himself (often log by log), Wyatt endured hunger, sickness, and even poverty throughout his ministry even after discovering the "faith principle" that ensured steady success. "I had to live on the razor's edge all the time," Wyatt admitted. ${ }^{26}$ Neither did he instruct his students otherwise. As a teacher at Des Moines Bible School, he sent his “students hitchhiking the highways to find God's place for their lives." ${ }^{27}$ Wyatt preached theological guarantees but, like many others, experienced everyday life with an ad hoc prosperity gospel.

Experimentalism prevailed over uniformity. Though proponents for divine prosperity could be heard throughout the decade, no single preacher offered the same guarantee. The Arkansas-native A. A. Allen called down money from the heavens, tying prosperity to the soaring supernaturalism of revivals. Hagin and Osborn, standing on the bedrock of Kenyon's theology, sounded most alike as they sporadically added finances to the inner workings of the "law of Faith." Roberts offered his own formula for prosperity in an assortment of mottos and personal testimonies. Yet taken together, their wide-ranging prescription for prosperity rested on an ironclad certainty that God, somehow, would provide.

The confidence that made Faith a spiritual and financial guarantee also characterized Pentecostalism's healing mandate. Mid-century healing evangelists called on a God who, through faith, altered reality in the present, not the future. Christian talk about hope had to be amended, for, as Kenyon claimed, "Hope says, 'I will get it

${ }_{25}^{25}$ Miller, Grappling with Destiny, 83, 134-135.

${ }^{26}$ Miller, Grappling with Destiny, 68.

${ }^{27}$ Miller, Grappling with Destiny, 69. 
sometime.' Faith says, 'I have it now.'” Christians that confessed that "the Lord is going to heal, help or deliver me" simultaneously implied that the Lord had not already done it. Tommy L. Osborn, an early proponent of the Faith message, lamented that "people erroneously pray: "God, heal this person if it be thy will." Instead, "expect a blessing from God." ${ }^{28}$ Faith Christians must proclaim a reality that they cannot see but must be believed because the Lord deemed it so. Countless healing testimonies reified this ideal. Thomas Wyatt, the Midwestern revivalist, testified that he recovered from his deathbed when he responded to God's audible voice saying, "I am the Lord that healeth thee." 29 He denied his grave condition in whispering back, "The Lord has come and healed me." He demanded to be lifted up, seated at the dinner table, and assisted in taking his first steps, acting out his healing despite his pain. His recovery echoes those of faith cure and early Pentecostal practices before him: "The return of strength was speedy after that, for faith had motivated action, and action had evidenced faith. The substance of faith had been grasped. For thirty days faith pushed Tom into act after act, until at the end of a month 'not a trace of the old sickness remained.'" ${ }^{30}$ Certainty, rather than hope, dictated their actions. ${ }^{31}$ Healing evangelists had little use for hope, lamenting the traditional and hope-filled Christians who prevented God from working on their behalf. ${ }^{32}$ Those who prayed that God was going to heal them sealed their own sad fate. A.A. Allen summed it up enthusiastically: "ACT YOUR FAITH ... Leave your wheel chair. Throw away your crutches. Walk and run! Leap for joy! . . Quit 'trying to believe.' Simply believe,

\footnotetext{
${ }^{28}$ T. L. Osborn, “Faith," Faith Digest, May 1956, 14.

${ }_{30}^{29}$ Miller, Grappling with Destiny, 31-32.

${ }^{30}$ Miller, Grappling with Destiny, 33.

${ }^{31}$ Simmons, E. W. Kenyon, 158.

${ }^{32}$ Charles Capps, Arkansas farmer and Faith teacher, gave hope a slightly better reputation, arguing that hope served as the "goal-setter" for Faith. Charles Capps, "Without Hope There Is No Faith," Charisma, August 1984, 54-60.
} 
and ACT." 33 The early faith message became just that-a theology in action-as healing evangelists attempted to bring meaning and order to the phenomenon they called Faith.

\section{Positive Faith}

The mid-century healing revivals that lifted the spirits (and expectations) of Pentecostals echoed the confidence resonating through postwar American society. Powerful voices trumpeted new Christian formulas for spiritual, physical, and financial abundance. Positive thinking abounded in the years following World War II, as Americans' optimism rose together with its burgeoning consumer culture. Rabbi Joshua Liebman's Peace of Mind (1946) introduced self-help to the inspirational mass market, followed shortly by best-sellers such as Claude Bristol's Magic of Believing (1948), Father James Keller's You Can Change the World! (1948), and Harry Overstreet's Mature Mind (1949). ${ }^{34}$ Norman Vincent Peale (1898-1993), Methodist minister and self-help writer, became the prophet of this generation. His early successes as a pastor in Brooklyn and Syracuse sealed his reputation as a cheery and anecdotal preacher with a knack for advertising and church growth. In the early 1950s, New Thought ideas began to figure prominently in his preaching. As his preaching drew larger audiences, Peale accepted a position at Marble Collegiate Church in New York City, a venerable Reformed Church of America (RCA) pulpit, from which he brought his message to a national audience.

The breadth of Peale's appeal lay in the fact that he made abstract theology into workable wisdom. Peale made countless appearances around the country, and, from the early 1950s, preached weekly to audiences of 4,000 at Marble Collegiate Church. He reached out to television audiences with his syndicated television program, What's Your

\footnotetext{
${ }^{33}$ Grant Wacker, "The Pentecostal Tradition," in Caring and Curing: Health and Medicine in the Western Religious Traditions edited by Ronald L. Numbers and Darrel W. Amundsen, (New York: Macmillan Publishing Company, 1986), 526.

${ }^{34}$ Andrew S. Finstuen, Original Sin and Everyday Protestants: The Theology of Reinhold Niebuhr, Billy Graham, and Paul Tillich in an Age of Anxiety (Chapel Hill, NC: University of North Carolina Press, 2009), 21.
} 
Trouble, which he co-hosted with his wife, Ruth. ${ }^{35}$ Radio listeners tuned into his syndicated program, The Art of Living, which spanned forty years. In 1945, he founded his own magazine, Guideposts, which gained four million readers over the next halfcentury. ${ }^{36}$ At Peale's peak, his published sermons garnered 150,000 readers and his syndicated newspaper column claimed an audience of ten million.

Peale's message was timely in two important ways. First, his use of psychological categories caught the rising tide of therapeutic culture in the United States. By the close of the 1930s, the new science of the mind had found mainline Protestant acceptance. Theological reckoning with mental health became commonplace as "pastoral psychology" integrated religious with scientific methods. Richard Cabot's The Art of Ministering (1936) and Rollo May's The Art of Counseling (1939) signaled that clinical models of pastoral advice giving were here to stay. Protestant seminaries drew psychology into standard coursework. ${ }^{37}$ In 1934, Peale sought the assistance of Smiley Blanton, professor of psychiatry at Cornell University Medical School, to help Peale counsel his parishioners. By 1937, the two had paired up to form the Marble Collegiate Church Clinic, a therapeutic center that integrated psychology and religion. Their coauthored book, Faith is the Answer: A Psychiatrist and a Pastor Discuss Your Problems (1940), joined the first waves of mainstream psychological services. ${ }^{38}$ Archbishop Fulton J. Sheen's 1954 book Way to Happiness and television show Life Is Worth Living soon offered a Catholic counterpart. ${ }^{39}$ By the end of World War II, Peale's psychological

\footnotetext{
${ }^{35}$ Roy Anker, Self-Help and Popular Religion in Modern American Culture: An Interpretive Guide (Westport, CT: Greenwood Press, 1999), 110.

${ }^{36}$ Anker, Self-Help, 111.

37 E. Brooks Holifield, God's Ambassadors: A History of the Christian Clergy in America, (Grand Rapids, MI: Eerdmans, 2007), 224.

38 Stephanie Coontz, Marriage, a History: How Love Conquered Marriage (New York: Penguin Books, 2005), $213,214,233-235$.

39 The show ran from 1951-1957, earning an Emmy and thirty million weekly viewers. Nancy Koester, Fortress Introduction to the History of Christianity in the United States (Minneapolis: Fortress Press, 2007), $177-178$
} 
idioms and impulses had blended into a culture already saturated with it.

Second, Peale's theological synthesis of upward mobility with religious buoyancy matched the post-war mood, turning a man into a movement. His blend of Methodist evangelism, Dutch Reformed Calvinism, and New Thought focus on mind-power appeared in earlier works, The Art of Living (1937) and You Can Win (1938). Yet as Peale's writing progressed, New Thought took precedence. In 1952, Peale authored The Power of Positive Thinking, which became a New York Times bestseller for a recordbreaking three years and sold a million copies. In it, he folded Christian and psychological categories into a New Thought theme: God's power could be harnessed by "a spirit and method by which we can control and even determine" life's circumstances." ${ }^{40}$ As Peale taught, any person could access God's own power through positive thinking, which directed spiritual energy toward the attainment of health, selfesteem, or business acumen, to name a few. Much like his New Thought predecessors, Peale promised formulas, patterns of right thought, and the release of power through effective words. ${ }^{41}$ Yet true to Peale's unique style, the book was not a systematic treatise of thought-power. Rather, it traded precision for anecdotal evidence and warm reassurances. Positive thinking followed a simple formula: "picturize, prayerize, and actualize." ${ }^{42}$ This articulation of middle-class aspirations, set on a pedestal by one of America's most popular mainstream preachers, blurred popular and elite religion. While Peale's teachings garnered heated opposition, his critics excoriated him for having made self-interest theologically respectable.

The degree to which Pentecostal healing revivalists consciously borrowed from positive thinkers like Norman Vincent Peale (or vice versa) remains unknown, but the

\footnotetext{
${ }^{40}$ Norman Vincent Peale, The Power of Positive Thinking (New York: Prentice Hall Press, 1987), vii.

${ }^{41}$ Peale, The Power of Positive Thinking, 2, 6.

${ }^{42}$ Peale, The Power of Positive Thinking, 55.
} 
record contains numerous clues that the two traditions frequently overlapped in these early postwar years. In 1949, Oral Roberts began a close partnership with S. Lee Braxton, a prominent Pentecostal businessman with a wholehearted devotion to positive thinking. Braxton shared his vast positive thinking library with Roberts, including How I Raised Myself from Failure to Success in Selling, a book Roberts later cited as the most influential he ever read. ${ }^{43}$ At the behest of Roberts, the Full Gospel Business Men's Fellowship International (FGBMFI) was founded in 1952 with Braxton as vice-president. It proved to be an institutional expression of Holy Spirit-filled positive thinking. In 1959, the young Pat Robertson and two fellow Pentecostals visited Ruth Peale to demonstrate the importance of speaking in tongues. ${ }^{44}$ One suspects that as the trio gave Ruth Peale a hearty exhibition they sought to give positive thinking its one missing ingredient:

charismata. At the very least, Pentecostals recognized that they had invested similar ideas and practices with theological significance.

Though none of the Pentecostal leaders adopted quite these terms at the time, we can reasonably call the Faith message positive thinking for its emphasis on the power of Christian speech to achieve results. Faith theology, like positive thinking, prized a different spiritual anatomy. Kenneth Hagin's exegesis of "Faith cometh by hearing, and hearing by the word of God" (Romans 10:17) concluded that the cycle of hearing and speaking activated faith. His revelation, recounted in Hear and Be Healed, constructed a doctrine that found widespread acceptance. ${ }^{45}$ To accumulate faith, believers engaged in

\footnotetext{
${ }^{43}$ Harrell, Oral Roberts, 115. As the historian Joseph Williams observed, the mid-century evangelists published an occasional article by Peale. In 1949, Roberts published Peale's article "Christ's Healing Power." In 1961, Gordon Lindsay's Voice of Healing published Peale's "How Faith Shapes Events." Williams, "Pentecostal Healing", 192.

${ }^{44}$ Harrell, Oral Roberts, 42. Robertson did not persuade Peale. As Harrell argues, "Charismatics simply added an overtly miraculous dimension to the body of positive thinking and success theology already present in American evangelicalism. In his 1982 book The Secret Kingdom, Robertson acknowledged that 'positive thinking will more often than not lead to successful action.' But he believed that charismatic faith was needed to unlock all the secrets of success." David Edwin Harrell Jr., Pat Robertson: A Personal, Religious, and Political Portrait (San Francisco: Harper \& Row, 1987), 114-115.

${ }^{45}$ See T. L. Osborn, One Hundred Divine Healing Facts (Tulsa: Harrison House, 1983), 19; John Osteen, What
} 
a perpetual process of allowing God's Word to filter into their hearts by hearing and speaking it out of their mouths. The act of hearing tied believers to God's power through faith. $^{46}$

Maintaining faith became a process of imbibing a steady stream of God's Word. This practice served as a reminder for believers to maintain their church commitments, since without church attendance saints could not hope to hear enough to sustain their faith. With the advent of audiocassettes in the late 1970s, celebrity preachers quoted this verse frequently to promote their sales, reminding the audience that only a steady diet of the spoken Word could fertilize their hearts. Oral Roberts-protégé Kenneth Copeland instructed listeners: "Your faith is in direct relation to the level of the Word in you. Get your Word-level up." ${ }^{47}$ Affirmations became common practices as churchgoers frequently displayed faith-building scriptures in the cars, homes, and workplaces to remind them to confess multiple times a day. Charisma magazine, for example, published a guide to positive confession as "GOS-PILLS," to be taken three times a day. ${ }^{48}$ The ascent to higher levels of faith could only take place with careful attention to the spiritual act of hearing.

Yet for God's Word to be heard, it had to be spoken. Faith bound itself to the spoken word. As Hagin opined, “A spiritual law too few of us realize is: Our confessions rule us." ${ }^{49}$ Speaking positive things, called positive confession, became a spiritual discipline. Believers expected their affirmations to release power (Faith) to

To Do When Nothing Seems to Work (Houston: Lakewood Church, 1981), 20. As Creflo Dollar summarized, "You gain potential [to act on faith] by hearing. I know faith comes when I hear God's Word." Dollar, Color of Love, 41.

46 As the movement progressed, Faith teachers grew certain that hearing was the only gateway to Faith. In 1956, Tulsa evangelist T. L. Osborn interpreted "faith comes by hearing God's Word" as an imperative to read Scripture. Later evangelists insisted on aural reception.

${ }^{47}$ Kenneth Copeland, The Laws of Prosperity (Greensburg, PA: Mann Christian Outreach, 1974), 27.

${ }^{48}$ Charles Capps, "Daily Dose," Charisma, April 1978, 23.

${ }^{49}$ Kenneth Hagin, In Him (Tulsa: Kenneth Hagin Ministries, 2006), 1. Like many others, this quotation came from Kenyon's Two Kinds of Faith. 
bring these assertions into reality. The first confession, which Hagin called The Great Confession, began with a confession of Jesus as Lord.

Confession: I believe in my heart Jesus Christ is the Son of God. I believe He was raised from the dead for my justification. I confess Him as my Lord and Saviour. Jesus is my Lord. He is dominating my life. He is guiding me. He is leading me. ${ }^{50}$

This emphasis on a declaration of faith put Faith teachers squarely in the company of evangelicals, who had made verbal confession a hallmark of the conversion experience. ${ }^{51}$ Yet while evangelicals focused on the personal relationship with God that such a declaration implied, Faith believers expected to share in God's power. As Kenneth Copeland explained, "God's power is in direct relationship with His Word. He has used His Word to release His Power. He has sent His Word to us so that we may be in contact with His great power." 52 Believers tap into God's power through the spoken word, which "works" when speakers possess the Faith to set God's Word in motion. A significant body of literature explained how Jesus' words and actions echoed God's Word, positively confessing realities into being. ${ }^{53}$ Consider that the term confession referred to every spoken word. Words uttered in prayer or anger, privately or publicly, not only tested character but also defined spiritual success or failure. Jesus said they did, Hagin insisted, for according to Mark 11:23, "Whosoever shall say . . . and shall not doubt in his heart, but shall believe that those things which he saith shall come to pass; he shall have whatsoever he saith." Hagin's Bible brimmed with promises, and Jesus' comment that "you shall have what you say" offered a guarantee. Faith became the

\footnotetext{
${ }_{51}^{50}$ Hagin, In Him, 12.

${ }^{51}$ Faith teachers parted company with evangelicals and other "born-agains" for their approach to the Word. Traditionally, the Word - the Logos-was equated with the divinity of Jesus. Jesus acted as the Word of the Father, delivered to the world. Early Pentecostals believed that simply uttering the word Jesus automatically expelled demons.

${ }_{52}$ Copeland, The Laws of Prosperity, 26-27.

${ }^{53}$ For an example of Jesus using positive confession, see Hagin, In Him, 6.
} 
force that would actuate believers' very words. ${ }^{54}$

A theological tradition of the power of speech-acts heavily leaned on Proverbs 18:21: "Death and life are in the power of the tongue: and they that love it shall eat the fruit thereof." Hagin and his followers affirmed that speech creates power and "Faith's confessions create realities." ${ }^{55}$ Some of the popular catchphrases from the movement focused on this unique characteristic, as people could "Name it and claim it." Midcentury healer W. V. Grant wondered whether it was necessary to pray for a miracle and reminded the sick to "look up and say...'Lord . . give it here'" ${ }^{\prime 56}$ Appendices listing suggested proclamations became a popular feature of Faith literature. ${ }^{57}$ Titles like $A$ Confession a Day Keeps the Devil Away made the purpose of such manuals clear. ${ }^{58}$ Because a believer's speech was so powerful, it had to be used carefully, always accentuating the positive and avoiding the negative and the lukewarm. A forceful recipe for actualizing God's promises seemed to rest on everyone's lips. ${ }^{59}$

Though Pentecostals could be convinced that their speech carried divine properties, they were never solely devoted to positive thinking. Pentecostals parted ways with Norman Vincent Peale in their devotion to tactile mediations of God's power. Miracle oil, water, handkerchiefs, and squares of tent cloth inspired testimonies as believers explained precisely how they received a blessing. Oral Roberts coined the phrase "points of contact" to describe the objects used as springboards to "release your

\footnotetext{
54 As Creflo Dollar summarized, "When God's Word is conceived in the heart, then formed with the tongue and spoken out the mouth, it becomes a spiritual force releasing the ability of God." Dollar, Color of Love, 43.

${ }_{56}^{55}$ Hagin, In Him, 9.

${ }^{56}$ W. V. Grant, "You Can Have Whatever You Say," Herald of Deliverance, March 4, 1951, 7.

${ }^{57}$ See, for instance, Marilyn Hickey, Speak the Word (Tulsa: Harrison House, 1983).

${ }^{58}$ Frances Hunter, A Confession A Day Keeps the Devil Away (Kingwood, TX: Hunter Books, 1980).

${ }^{59}$ Not everyone taught that only spoken words were powerful words. Creflo Dollar argued that it was not the only way to release Faith, but that it was "a difference in the degree of power when it comes out of your own mouth." Dollar, Color of Love, 42. See also John Avanzini, It's Not Working, Brother John: 25 Things That Close the Windows of Heaven (Tulsa: Harrison House, 1992), 141-146; Kenneth Copeland, Dear Partner (Fort Worth, TX: Kenneth Copeland Publications, 1997), 64-68.
} 
faith toward God." 60 These practices chafed against their simultaneous teaching about God's invisible laws, which already supplied a mechanism for how God transformed Faith into blessing. Faith, like gravity, operated as an immutable and repeatable law of cause and effect. What else was necessary? Yet Pentecostalism's material devotional culture, older than the Faith movement itself, pervaded prosperity theology as another reflection of its thoroughgoing materialism. If Faith could produce material results, health and finances in particular, then why couldn't material objects help Faith along?

Blessed objects served as one of the hallmarks of Faith ministries. ${ }^{61}$ Anointed handkerchiefs, following the biblical (and early Pentecostal) precedent, were the most commonly used items. ${ }^{62}$ In 1952 , Oral Roberts mailed out 140,177 prayer cloths to supporters. ${ }^{63}$ As revival organizer Gordon Lindsay explained, the anointing that rests "upon a minister or even the regular lay members . . . may be retained by a piece of cloth." ${ }^{64}$ Proximity mattered, as prolonged exposure to the anointed person typically increased the cloth's power. A. A. Allen sold pieces of his tent as "prosperity cloths" with the understanding that the tent itself absorbed his anointing. "Miracle water" drawn from his "Pool of Bethesda" at his Miracle Valley headquarters in Arizona demanded more circuitous logic. ${ }^{65}$ Books and periodicals served the same function.

\footnotetext{
${ }^{60}$ Harrell, All Things Are Possible, 92. The term "point of contact" surfaces in Andrew Murray's book Divine Healing (1884) in reference to anointing oil and the laying on of hands. See Paul L. King, Only Believe: Examining the Origin and Development of Classic and Contemporary Word of Faith Theologies (Tulsa: Word and Spirit Press, 2008), 272.

${ }^{61}$ In this, the Faith movement recovered a tradition that had evaporated in mainline Pentecostalism by midcentury. Early Pentecostals held that their periodicals resonated with sacred healing power and should be handled reverently. See Grant Wacker, Heaven Below: Early Pentecostals and American Culture (Cambridge, MA: Harvard University Press, 2001), 94; R. Marie Griffith, "Material Devotion: Pentecostal Prayer

Cloths." Interview in the Material History of American Religion Project Newsletter (Spring 1997): 1-3, available at http:/ / www.materialreligion.org/journal/handkerchief.html (accessed July 13, 2009.) These practices echoed historic Christian practices typically reserved for handling the sacrament.

${ }^{62}$ In Acts 19:12, Paul's anointed handkerchief cures the sick.

${ }^{63}$ Harrell, All Things Are Possible, 43-44,

${ }^{64}$ Gordon Lindsay, Bible Days Are Here Again: Divine Healing for Today and God's Plan for Ending Sickness (Shreveport, LA: G. Lindsay, 1949), 139. "When the handkerchief is applied to the afflicted part of the body, the individual may find it helpful at that moment to place his hand on the Bible on the page indicated in Acts 19 , and then at once begin to praise God for healing.... It has come to the author's attention that the number of people healed in this manner is larger than might be supposed." Lindsay, Bible Days, 140.

55 James Randi, The Faith Healers (Buffalo, NY: Prometheus Books, 1987), 87.
} 
Testimonies of magazines placed under pillows or placed like bandages on wounds described their hidden power. Others commonly placed one hand on the Bible and another on the evangelist's publication to establish the book as a "point of contact." With the advent of television in the 1950s, participants sometimes touched the screen. "I felt a magnetic pull toward the television set," testified Jean Carmack. "When Brother Roberts asked those in the audience who wanted healing to put their hand on the television set and pray with him in faith I did so. . . . I felt His power surge through my whole being, pushing the pain completely out of my body." ${ }^{66}$ Points of contact required not only belief but also the willingness to act. A photo in Abundant Life captured Oral Roberts University's “World Action Singers" performing the release of faith. The singers, dressed in smart uniforms, reached their hands toward the sky in unison; the caption reads: "With our hands we express our compassion for those in need and as a point of contact for the releasing of our faith for deliverance." In handkerchiefs, television, or song, believers felt faith course through material mediums and into tangible results. In this, the logic of Faith came full circle. Health and wealth came to those who peered beyond the material and saw the invisible operation of spiritual laws. As such, Faith theology reconfigured the unshakable materialism of Pentecostal culture, suffused as it was with anointing oil, healing hands, and blessed handkerchiefs. Borrowing from 2 Corinthians 5:7, practitioners sought to "walk by faith and not by sight." And yet the goal was never to wean believers from material "points of contact." Faith teachers constantly mailed out ribbons, kerchiefs, and oils to mediate God's divine truth and remind people of the spiritual world just beyond their reach.

\footnotetext{
${ }^{66}$ Testimonies. “Television was our point of contact," Abundant Life, February 1969, 11.
} 


\section{Charismatic Faith, 1958-1975}

Despite its reputation as an era of sex, drugs, and rock and roll, the 1960s in America saw a continued interest in religion and in new forms of religious expression. It is true that by the early 1960s, the healing revival had sputtered and slowed. Financial support for its roaming prophets dried up as Pentecostals wearily surveyed a spiritual market flooded with miracles, evangelists, and wonders. Gordon Lindsay, the revival's able publicist, blamed evangelists' ambition and the increasing focus on money ${ }^{67}$ Though Lindsay's own God's Master Key to Success and Prosperity (1959) served as one of the most popular books on divine wealth, he worried that the revival had gone too far. ${ }^{68}$ Donald Gee, editor of World Pentecost, also suspected that fraud on the part of a few had ruined it for all. The garish showmanship that marked excesses of the revival had tainted public perception of the whole. Yet changes outside Pentecostalism's historic walls brought unexpected renewal.

In April 1960, Dennis J. Bennett, rector of St. Mark's Episcopal Church in Van Nuys, California, announced to his thriving congregation that he had received Holy Spirit baptism. His public declaration that he had spoken in tongues (glossolalia), and the hundreds of his parishioners who soon followed his example, marked the beginning of the "Charismatic movement." Mainline Protestant denominations-such as the American Lutheran Church, the United Presbyterian Church, the American Baptist Church, and the United Methodist Church-awakened to charismatic influences. In 1967, this revival surged within the Roman Catholic Church. Ecumenism flowered through figures such as David Du Plessis, otherwise known as "Mr. Pentecost." He informally represented Pentecostalism on a global stage as an observer of Vatican II,

\footnotetext{
${ }^{67}$ Harrell, All Things Are Possible, 139.

${ }^{68}$ Gordon Lindsay, God's Master Key to Success and Prosperity (Dallas: The Voice of Healing Publishing Company, 1959).
} 
member of the National Council of Churches (NCC), and chair of the Roman CatholicPentecostal dialogue team. ${ }^{69}$ Yet the movement's diverse leadership and participants prevented any one person from claiming to represent the center. Rather, interest in the Holy Spirit flowed like water through congregations. As Vinson Synan observed, "It was not unusual to see a Catholic priest, an Episcopal pastor, and a Pentecostal evangelist sharing the same platform at Full Gospel Business Men's dinners or the thousands of other conferences, revivals, crusades, and missions sponsored by a multitude to churches and parachurch organizations." ${ }^{70}$ By 1975, the charismatic revival claimed five million souls. ${ }^{71}$

As the momentum of the post-war Pentecostal healing revivals crested in the charismatic movement, the lessons learned under tent canopies were not soon forgotten. ${ }^{72}$ Yet evangelists discovered that the qualities that endeared them to boisterous outdoor spectacles did not suit the new charismatic temperament. If healing evangelism was "outdoor" religion, the charismatic movement was surely made to stay indoors. The unvarnished crusades of the 1940s and 1950s gave way to polished messages, better suited for conference centers than sawdust trails. In many ways, these changes reflected the taste of the educated, middle-class clientele ushered in by the charismatic movement. Teachers, rather than healers, led the growing revival with a focus on spiritual finances and institution building. Many leaders no longer required the platform skills that once kept Pentecostal audiences spellbound, as the staid settings of auditoriums and hotel ballrooms favored careful exposition over improvisation. In this

\footnotetext{
${ }^{69}$ Vinson Synan, The Century of the Holy Spirit: 100 Years of Pentecostal and Charismatic Renewal, 19012001 (Nashville: Thomas Nelson Publishers, 2001), 362.

${ }^{70}$ Synan, Century of the Holy Spirit, 363.

${ }^{71}$ Harrell, All Things Are Possible, 3.

${ }^{72}$ To be sure, the charismatic revival did not snuff out the Pentecostal healing revivals. They persisted in independent venues and in traditional Pentecostal churches.
} 
new climate, Faith teachers thrived as audiences sought Pentecostal ideas with modern sensibilities.

In these years, many middle-class Americans began to consider non-Christian approaches to religious life, along with the notion that believers might access supernatural power through nontraditional means. ${ }^{73}$ A number of movements, dismissed as "cults" by the media, captured the attention of troubled celebrities and students on campuses across the United States. A pantheon of gurus made appearances promising spiritual gifts through ancient techniques, recent revelations, or modern drugs; figures such as the Maharishi Mahesh Yogi, Baba Ram Dass, the Reverend Moon, Maharj-ji, Timothy Leary, Moses David, and L. Ron Hubbard became widely known. Some of these new religions-Scientology and Transcendental Meditation, for example-claimed (like the Faith movement) to have discovered universal spiritual laws that adepts could access. ${ }^{74}$ Soon homemakers were chanting mantras, movie stars were being hooked up to e-meters, and bishops were experimenting with the consciousness-expanding powers of LSD, séances, or peyote. As one evangelist observed, “I don't know what; there's something happening. ... . But people ... they're more interested in pentecostalism and the occult, mysticism, Buddhism, eastern religions. There's a tremendous interest in the unknown. And pentecostalism is a mystical thing." ${ }^{75}$ As guardians of the unseen world of Faith, prosperity teachers joined an age of mystics in offering a spirit-filled guide to the numinous.

The 1960s and early 1970s saw most of these movements disappear as quickly as they had flared up. Mantras were forgotten, gurus were arrested for fraud and

\footnotetext{
${ }^{73}$ See Phillip Jenkins, Mystics and Messiahs: Cults and New Religions in American History (New York: Oxford University Press, 2000), 187-207. To see themiddle-class constituency of Rev. Moon's followers, see Thomas Robbins, "Last Civil Religion: Reverend Moon and the Unification Church," Sociological Analysis 37, no. 2 (Summer 1976), 111-125.

${ }_{74}$ Transcendental Meditation, for example, conducted some of its activities under the banner of the Natural Law Party.

${ }^{75}$ Harrell, All Things Are Possible, 146.
} 
ashrams were abandoned, but the Faith movement prospered. During that time, Faith believers moved from being a side act in Pentecostal revivalism to center stage. By the 1970s, the Faith message was respectable. New, affluent audiences had granted its revivalists the financial foundation to build sprawling ministries. Nothing represented this shift better than the rise of the Full Gospel Business Men's Fellowship International. Founded in 1952, the organization spread rapidly as an association of charismatic businessmen who gathered in local chapters and annual conferences across the country. It served as a faithful companion to independent Pentecostal revivalists, not only in its distance from Pentecostal denominations, but as a popular platform for ministers like Oral Roberts, John Osteen, Jack Coe, William Branham, and Kenneth Hagin. By the early 1970s, the fellowship boasted a membership of 300,000 and an annual budget of more than one million dollars. ${ }^{76}$

Those who had championed prosperity during the healing revivals now found that their time had come. Tommy and Daisy Osborn, famous for their overseas evangelism, turned to wholesale prosperity with their "Pact of Plenty," the promise of financial blessings to those who donated (particularly to the Osborn ministry). A. A. Allen, in numerous publications including The Secret to Scriptural Financial Success (1953), Your Christian Dollar (1958), and Power to Get Wealth (1963), charted the straight path to divine wealth. ${ }^{77}$ Seasoned prosperity teachers Oral Roberts and Kenneth Hagin excelled among charismatic revivalists at building new centers of institutional strength and the Faith movement itself. Founded in 1962, Oral Roberts University brought academic repute and ministerial credentials to upcoming and likeminded teachers. Within a

\footnotetext{
${ }^{76}$ Harrell, All Things Are Possible, 147. I found less evidence that the female counterpart to the FGBMFI, The Women's Aglow Fellowship, promoted Faith teaching. For a history of their organization, see R. Marie Griffith, God's Daughters: Evangelical Women and the Power of Submission (Berkeley: University of California Press, 1997).

${ }_{77}$ A. A. Allen, The Secret to Scriptural Financial Success (Miracle Valley, AZ: A. A. Allen Publications, 1953); A. A. Allen, Your Christian Dollar (Miracle Valley, AZ: A. A. Allen Publications, 1958); A. A. Allen, God's Guarantee to Bless and Prosper You Financially (Miracle Valley, AZ: A. A. Allen Publications, 1969).
} 
decade, the school won accreditation and academic standing. Likewise, Oral Roberts's FGBMFI and its magazine Voice granted the scattered revivalists a strong measure of institutional cohesion. ${ }^{78}$ Hagin joined the upper echelon of teachers in founding the Kenneth E. Hagin Evangelistic Association in 1962 with a new headquarters in 1966 in Tulsa, Oklahoma, Oral Roberts's backyard. In 1974, Hagin founded Rhema Bible Training Center in Tulsa as an official organ of his prosperity theology, called "Word of Faith" after his popular magazine of the same name. Both institutions provided both the ministerial credentials and the national exposure, through their annual conferences, to launch the careers of countless pastors.

New Faith teachers such as Frederick Price, John Osteen, and M. G. "Pat" Robertson, inspired by the far-flung charismatic movement, left traditional churches to found independent Faith ministries. It was typically a two-step conversion. Faith teacher John Osteen famously broke with the Southern Baptists to found the Lakewood Baptist Church of Houston in 1959 after his baptism of the Holy Spirit won him to the charismatic cause. Several years later, his discovery of the Faith message transformed his focus from How God Baptized Me In the Holy Ghost and Fire (1961) to You Can Change Your Destiny (1969). After speaking in tongues, former Southern Baptist Pat Robertson also turned first to Pentecostalism and then to Faith teaching.

Kenneth Copeland emerged as one of the new stars of the movement. Kenneth and Gloria Copeland moved to Oklahoma in the fall of 1966, eager to attend Oral Roberts University, where Kenneth soon came to the ministry's attention. As a pilot and former pop singer, his talents suited his new employment as Roberts's pilot, chauffeur, and touring singer with the ministry. As Copeland worked and studied under the auspices of Oral Roberts's famous healing ministry, he also became a follower of another

\footnotetext{
${ }^{78}$ Harrell, All Things Are Possible, 181.
} 
Faith giant: Kenneth Hagin. Starting in 1967, Hagin's denominational prosperity teaching, Word of Faith, taught Copeland a new vocabulary to describe the relationship between belief and materiality. Copeland adopted Hagin's understanding of "positive confession," the spoken word bringing circumstances into reality, with such conviction that he offered to trade his car to Hagin's ministry for another set of Hagin's taped teachings. ${ }^{79}$ With Hagin's teachings on positive confession, Oral Roberts's healing ministry, and a developing theology of finances, Copeland's distinctive brand of Faith theology took shape. On September 7, 1967, the couple founded Kenneth Copeland Ministries (KCM).

A. A. Allen seemed less than pleased with so many evangelistic pretenders to his throne: "Humbly I tell you this," he told readers, "as reports are reaching my headquarters that ministers all over the country are preaching about the blessing of prosperity.... God told me he had given me power to bestow power to get wealth. He did not say it was given to Tom, Dick and Harry, or to just anyone who says 'Lord, Lord. '" ${ }^{80}$ But it was too late. The secret was out.

Divine wealth replaced healing as the focus of revivalism as Faith ministries increased in respectability and financial clout. Titles like Morris Cerullo's A Guide to Total Health and Prosperity, Kenneth Copeland's The Laws of Prosperity, and Rex Humbard's Your Keys to God's Bank confirmed that charismatic audiences, spread across denominations, sought miracles different from their Pentecostal predecessors. Oral Roberts urged a measured approach in his published prayer guides, Daily BLESSINGS. His "Blessing Prayers" for January 1961, for instance, urged readers to keep the following regimen: ${ }^{81}$

\footnotetext{
${ }^{79}$ Billingsley, It's a New Day, 67.

${ }^{80}$ Harrell, All Things Are Possible, 200.

${ }^{81}$ Oral Roberts, Daily BLESSINGS 1961, vol. 3, Introduction.
} 
8 a.m. Pray for Spiritual Progress

10 a.m. For Those Without Christ

Noon: For Healing

6 p.m. For Prosperity

9 p.m. For the World.

Yet few teachers counseled such temperance. Checks printed with prosperity proof-texts sealed personal finances with divine favor. The Baltimore radio evangelist $\mathrm{R}$. G. Hardy, known for his gold prosperity cloths, promised God would "give you prosperity to get you to do his will." ${ }^{82}$ Don Stewart inherited A. A. Allen's ministry and his "hard-sell" tactics with similar intensity; he advertised his ministry with blunt headlines like, "God wants you to be a winner." ${ }^{83}$

By the 1970s, virtually every major charismatic teacher accepted positive confession as a doctrinal standard and the means of achieving divine wealth ${ }^{84}$ Kenneth Copeland put it simply: "The confession of your mouth will cause you to possess it." ${ }^{85}$ "Our mouths are the way we cast our vote," summarized another. ${ }^{86}$ The old-fashioned tent minister Robert Schambach and protégé of A. A. Allen continued to offer messages of prosperity and positive faith to the poor after Allen's death. Even David Terrell, known for his radical prophecies and frustration with the modern messages of his charismatic contemporaries, promoted prosperity in his The Gift of Prosperity and Health

\footnotetext{
${ }^{82}$ R. G. Hardy, Faith in Action, May 1972, 5.

${ }^{83}$ Advertisement. Charisma, October 1978.

${ }^{84}$ That is not to say, however, that every teacher featured it in their ministry. Gordon and Freda Lindsay, for example, had supported Hagin. Freda even edited Hagin's first book. Their post-revival ministry, Christ for the Nations, focused on international evangelism in a manner that was compatible with (but not a duplicate of) Hagin's theology.

${ }^{85}$ Copeland, Laws of Prosperity, 99.

86 Terry Law, "The Power of Praise and Worship," in Principles of Praise, (Tulsa: Victory House, 1985),

145-56. See also John Osteen, There Is a Miracle in Your Mouth (Houston: John Osteen Ministries, 1972).
} 
(1982). "Claim Him as Your Source right now," wrote the evangelist Morris Cerullo before leading readers in a prayer for God's "abundant flow of increase." ${ }^{87}$

The preeminence of prosperity theology prompted some teachers to attempt to reconcile divine wealth with the realities of the missionary field. The evangelist David Nunn's The Healing Messenger featured emaciated children with distended bellies looking out from the cover under headings such as "Fill My Cup Please." Inside, Nunn taught the principles of financial sowing and reaping, assuring readers that "the proper use of faith brings God's richest blessings to all of us." ${ }^{88}$ His magazine encouraged readers to make "Faith Promises" and "Seed Faith Gifts," donations that would bring individual and communal reward: "If you will act in faith today, I believe that this will be the turning point in your life in victory and blessings." ${ }^{89}$ The globetrotting minister Lester Sumrall's World Harvest chronicled Sumrall's foreign missions with accounts of extraordinary supernaturalism, witchdoctors conquered, and illness vanquished by God's healing power. Even there, articles concerning "God's divine law of compensation" peppered the magazine. ${ }^{90}$ T. L. and Daisy Osborn stuffed Faith Digest with newsy updates and hundreds of photographs of overseas crusades, interspersed with reminders that prosperity theology yielded abundant returns for American readers. Though compassionate evangelism was in keeping with Pentecostal missions, critics pointed out that it failed to answer the question: why not just teach them the law of Faith?

Yet here caution is in order, as those who preached Faith did not always do so exclusively. Many evangelists accepted Faith as one of many doctrinal standards. Derek Prince, a respected academic-turned-evangelist, proved best known for his leading role in the 1970s with the controversial "Shepherding/Discipleship movement" that

\footnotetext{
${ }^{87}$ Morris Cerullo, A Guide to Total Health and Prosperity (San Diego: World Evangelism Inc., 1977), 73.

${ }^{88}$ David Nunn, The Healing Messenger, March 1977, 10-11.

${ }^{89}$ Ibid.

${ }^{90}$ C. C. Ford, “God's Divine Law of Compensation," World Harvest, January 1963, 5. For his shared language of faith as activator, see Gerald Pope, "Your Faith Can Make It Happen," World Harvest, April 1964, 4-5.
} 
attempted to overcome the excesses of independent ministries by proposing spiritual submission to other ministers (including himself, Bob Mumford, Charles Simpson, Ern Baxter, and Don Basham.) When the Discipleship movement fell into disfavor in the early 1980s, he continued to be a popular authority on demonic deliverance and positive confession. Pentecostal megachurch pastor Tommy Reid attributed his success to having accepted not only the Faith message, but also the Catholic charismatic movement and the shepherding message. "Pastor Reid is so open to all aspects of the body of Christ," his associate pastor said admiringly. ${ }^{91}$

Pat Robertson also fit awkwardly into the mold of previous Faith teachers. Educated at the College of William \& Mary and at Yale, this Pentecostal with a penchant for prophecy and politics also devoted himself to ferreting out the spiritual laws that governed The Secret Kingdom (1982). Robertson argued that faith would unlock the power of eight Kingdom laws, secrets of success available to all Christians. Though he frequently distanced himself from Faith teachers, he agreed with their major premises: "We have the title deed to what God has promised. Our role is to believe in our hearts that it has been accomplished, according to what God has given the deed to, and then to speak it." 92

By the late 1970s, the ecumenical dream that sustained the charismatic movement had faded. Mainline and Catholic interest in Pentecostal worship in their congregations waned, diluted by diminishing curiosity and official denominational attempts to regulate its practice. Historic denominations no longer sought to build theological and institutional unity with their Pentecostal brethren with the same fervor. Yet a door between Pentecostal and traditional churches had been opened. Churchgoing Lutherans, Presbyterians, Episcopalians, and Catholics, to name only a few, looked at Holy Spirit-

\footnotetext{
${ }^{91}$ Steve Haggerty, “A Pastor's Heart Opens as his Church Overflows," Charisma, March 1985, 56-60.

92 Pat Robertson and Bob Drosser, The Secret Kingdom (Nashville: Thomas Nelson, 1982), 67. 
filled teachers with new interest. To the swelling ranks of Faith teachers, non-Pentecostal supporters proved to be an unexpected boon. We might call them Monday-throughSaturday followers for their interest in prosperity conferences, publications, and media, despite their Sunday attendance at a traditional congregation. The movement ballooned with these new audiences for their spiritual solutions to pain, poverty, and despair, popular support that outlasted the charismatic revival itself.

\section{African American Faith}

African Americans formed a distinct community within the developing Faith movement, as fissures dividing black from white saints ran deep and wide through Pentecostalism. White Faith teachers like A. A. Allen and Oral Roberts earned large followings among African Americans as the gains of the civil rights movement created modest attempts among Pentecostals to bridge the gap. Black musicians increasingly joined white Faith teachers on stage as the supporting cast of revivalism. Yet the rise of independent black revivalists in this period not only won numerous African Americans to Faith teaching, but also remade the Faith movement in their image.

The Reverend Frederick J. Eikerenkoetter (1935-2009), known as Reverend Ike, gave the African American prosperity gospel its first national platform. As a southerner who migrated to the black urban north and blended Pentecostal and spiritualist traditions, Reverend Ike's ministry echoed many of the metaphysical prosperity theologies of the first half of the twentieth century. Reverend Ike's flashy jewelry, conked hair, and tailored suits reinforced his expansive message of abundance, summed up in catchphrases like "you can't lose with the stuff I use," and "the lack of money is the root of all evil." ${ }^{93}$ In 1969, Reverend Ike moved his United Church of Jesus Christ for All People to the New York City neighborhood of Washington Heights, where he refurbished

\footnotetext{
${ }^{93}$ Harrell, All Things Are Possible, 235.
} 
a theatre into a 3,500-seat, gilded worship facility, capable of broadcasting his services to national television and radio audiences.

His evolving theology took on new metaphysical fervor, setting aside Pentecostal messages for a New Thought-inspired "Science of Living." Reverend Ike heated up the genteel reassurances of Norman Vincent Peale's positive thinking into glittering promises of material wealth, channeling mind-power toward tangible rewards. He implored believers to change their circumstances for the better rather than rely on a heavenly reward, aptly summarized in his famous saying, "Don't wait for your pie in the sky by and by; have it now with ice cream and a cherry on top." ${ }^{94}$ Yet Reverend Ike also patterned his ministry and message after Oral Roberts, whose denominational independence, financial focus, and creative fundraising techniques he admired. ${ }^{95}$

Reverend Ike's emphasis on the mechanism of Faith likely resulted from the stronger measure of metaphysical mental magic he injected into the prosperity gospel. Although other Faith teachers, black and white, rejected any metaphysical (and therefore non-Christian) legacy and distanced themselves from the flamboyant Reverend Ike, no one forgot his dramatic promises of material wealth for the right-thinking Christian. Reverend Ike's popular message served as a sturdy bridge, across which subsequent preachers and participants carried a black metaphysical—and heavily instrumental—Christianity into the future. ${ }^{96}$

From within the Pentecostal tradition, new African American leaders carved out a place in the predominately-white spheres of Faith. Frederick K. C. Price, who counted himself the theological heir of Kenneth Hagin and Oral Roberts, became the preeminent

\footnotetext{
94 Jonathan L. Walton, Watch This! The Ethics and Aesthetics of Black Televangelism (New York: New York University Press, 2009), 50.

${ }^{95}$ Don Stewart latter recalled that Reverend Ike studied theministries of Oral Roberts, Kathryn Kuhlman, and A. A. Allen. Don Stewart, Only Believe: An Eyewitness Account of the Great Healing Revivals of the $20^{\text {th }}$ Century (Shippensburg, PA: Revival Press, 1999), 111.

${ }^{96}$ Jonathan Walton, argues that Reverend Ike served as a "connectional" figure between the interwar and contemporary black prosperity theologies. Walton, Watch This!, 73.
} 
African American prosperity preacher. In 1970, Price's experience of the Holy Spirit pulled him away from traditional black denominations and toward the white Faith circles of Hagin, Roberts, and Copeland. His crusades, publications, sprawling megachurch, and nationwide television program advanced the charismatic renewal that had captivated black churches in the 1980s and 1990s." ${ }^{97}$ Carlton Pearson, reared within the Church of God in Christ, also pioneered Faith teaching among African Americans. As a protégé of Oral Roberts, he toured with Oral Roberts's son Richard and the ORU World Action Singers to promote the university's interracial character. In 1977, Pearson struck out on his own as a traveling evangelist and founding pastor of Higher Dimensions Evangelistic Center in Tulsa. In 1988, he founded his famous Azusa conference as a staging ground for up-and-coming African American singers and preachers to gain recognition.

After the late 1970s, prosperity theology rose with new vitality in African American religion. ${ }^{98}$ Price, alongside Keith Butler, Leroy Thompson, Eddie Long, Creflo Dollar, T. D. Jakes, and an emerging generation of black prosperity preachers, reflected the optimism of a rising black middle class, who thirsted for a gospel that made sense of their newfound economic gains. They became prophets of what the historian Scott Billingsley has termed a "second wave" of the neo-Pentecostal movement. This second wave washed black congregations-Pentecostal and historic black denominations alike-with an ideology of upward mobility dominated by Hagin's theology. The Grammy award winning Clark Sisters went from singing "Nothing to Lose" to "Name It, Claim It." African American Faith believers remained a distinct community, as its churches and leaders proved to be densely networked. For example, Friends International Christian University, a distance-learning institute centered in Florida,

\footnotetext{
${ }^{97}$ Billingsley, It's a New Day, 13.

${ }^{98}$ Billingsley, It's a New Day, 104-129.
} 
granted honorary doctorates to the highest rung of African American Faith teachers, including megachurch pastors T. D. Jakes (Dallas), Clarence McClendon (Los Angeles), Paul Morton (New Orleans), Dick Bernal (San Jose), and Ira Hilliard (Houston). African American Faith churches spanned more denominations than their white counterparts, drawing from historic black mainline churches, Pentecostal, charismatic, and nondenominational congregations. Though black and white Faith believers remained separated at the congregational level, African American teachers dominated the national scene and played a vital role in the creation and direction of the Faith movement. William Seymour, an African American leader of early Pentecostalism, would have been pleased to see that, from the 1970s onwards, Faith believers attempted to build bridges across the racial crevices that had divided Pentecostalism from its earliest days.

\section{Cohesive Faith}

By the late 1970s what began as a minority teaching within independent Pentecostalism had evolved into a powerful movement. This brings us finally to what I mean by the term movement. In tracing its inception in the Pentecostal healing revivals to its maturity in the charismatic movement, I have been referring primarily to a cluster of ideas and desired practices that defined the use of Faith. As noted, diverse teachers shared a vision of universal spiritual laws that drew blessings from the spiritual plane for earthly use. Though the language varied, and not all used Hagin's term “law of faith," the movement relied on a heavily instrumental definition of faith. Kenneth Copeland spoke for many when he compared faith to a wrench, a tool that "can be controlled. . . Y You can turn it off, or turn it on." ${ }^{99}$ Though the finer points of Faith theology mattered, faith was faith only because it worked.

\footnotetext{
${ }^{99}$ Stephen Strang, “Kenneth Copeland," Charisma, June 1979, 16.
} 
The Faith movement in the late 1970s claimed not only a shared theological platform, but also a newly stabilized base of publications, conferences, associations, and television programs though which pastors promoted their own ministries and those of fellow Faith teachers. In many respects, the Faith movement duplicated the successes of the healing and charismatic revivals that preceded it. Magazines still served a vital role in spreading the word. In 1973, over two million households received old-time revivalist W. V. Grant's The Voice of Deliverance. ${ }^{100}$ Oral Roberts, Kenneth Hagin, and Kenneth Copeland considered their flourishing magazines a major evangelistic tool. Charisma magazine, founded in 1975 "to meet the needs and demands of the Charismatic renewal community," soon became one of the most popular supporters of the Faith movement. ${ }^{101}$ Itinerancy proved as popular as ever. Kenneth and Gloria Copeland stood at the top of the heap, as their "Victory Seminars" took them in a yearly circuit of almost two-dozen major cities for a total audience of 80,000. Francis and Charles Hunter, known as the Happy Hunters, brought their healing revivals and prosperity theology to hundreds of American cities. The personal connections that invigorated postwar independent Pentecostalism still coursed through the Faith movement, only an observer might have to look in different places. Favored friends not only could expect an added advertisement for their upcoming crusade, but a seat on a university advisory board or even an honorary degree.

Entrepreneurial to the bone, few opportunities eluded them. Faith proponents responded to the 1970s boom in religious book sales with characteristic enthusiasm, flooding the market with Faith publications. ${ }^{102}$ The transition came easily for most major ministers, who already owned their own publishing companies. In 1975, Kenneth Hagin's

\footnotetext{
${ }^{100}$ Harrell, All Things Are Possible, 173.

101 Stephen E. Strang," 10 Growth Stages for Charisma," Charisma, August 1985, 172.

102 Stephen Strang," The Christian Book Boom," Charisma, April 1978, 14.
} 
son-in-law Buddy Harrison founded Harrison House as a general publishing house for Faith literature. Soon prosperity books, much like early twentieth-century success literature, swelled the ocean of cheap paperbacks.

Successful teachers won organizers and crowds alike. The largest independent ministries sponsored annual conferences that became a steady evangelistic circuit for other popular teachers, forging strong connections between far-flung teachers. Wellattended conferences featured the same roster of teachers, mixed and matched from only a few dozen names. Availability, talent, and preference surely played their role. Hagin's annual "Campmeeting" drew some of the largest crowds and the closest allies to "Word of Faith" theology, teachers like Kenneth Copeland, John Osteen, and Frederick Price. The highest honors went to featured speakers of the FGBMFI World Conventions, Faith giants like Oral Roberts, Pat Robertson, and Kenneth Hagin. Yet conference platforms favored more than the mighty. Those with modest reputationsNorvel Hayes, John Gimenez, Marilyn Hickey—used conferences as opportunities to hone their skills and garner wider audiences. Connection was the lifeblood of independent ministries, and conferences pumped fresh faces and crowds into circulation.

By the late 1970s, Faith teachers began to cement their informal connections among diverse ministries by joining associations. The latter, alternatively called fellowships, acted as voluntary societies of ordained ministers. Unlike denominations, fellowships did not ordain ministers or oversee the ministries of their members. These loose-knit communities typically shared little more than a brief faith statement, an annual conference, and the company of fine colleagues. In 1978, Jim and Kathleen Kaseman founded the Association of Faith Churches and Ministers (AFCM) "to promote fellowship among the ministers who shared his vision of taking the 'Word of Faith' 
message to the world." ${ }^{103}$ With growing numbers of new churches and ministries founded in the name of Faith, Jim Kaseman, a graduate of the charter class of Rhema Bible Training Center, sought to bring much-needed resources to their growing ranks. The following year Buddy Harrison, Kenneth Hagin's son-in-law, organized the International Convention of Faith Ministries (ICFM) as a voluntary organization of ministers bound by their commitment to the Word of Faith. The Louisiana pastor Charles Green founded the Network of Christian Ministries in 1984. The Rhema Ministerial Association (RMAI), founded in 1985, soon followed to provide Rhema graduates with the benefits of official alumni support. The proliferation of Faith associations meant more choice, but not necessarily more competition. Teachers joined more than one as badges of belonging. The best part was getting in.

A handful of megachurches stood out as strongholds of Faith teaching. Lester Sumrall's Cathedral of Praise (South Bend, Indiana), John Osteen's Lakewood Church (Houston), Karl Strader's First Assembly (Lakeland, Florida), Marilyn and Wally Hickey's The Happy Church (Denver), Roy and Pauline Harthern's Calvary Assembly (Orlando) and Charles and Barbara Green's Word of Faith Temple (New Orleans) gained national recognition as vital congregations and popular settings for radio and television broadcasts of their services.

Yet the heyday of Faith megachurches had not yet come. By the late 1970s, ministers educated by Rhema Bible Training Center and other like-minded schools were still too green. Commissioned as missionaries, the first graduating classes set out to experience the thrilling demonstrations of Faith at work. These eager novices fanned across the United States and Canada to found hundreds of congregations. Though many graduates struggled through the lean years of small time ministry, the success of the few

\footnotetext{
${ }^{103}$ Dr. Jim Kaseman, Association of Faith Churches and Ministers, http: / / www.afcminternational.org / aboutus.php?page=jk (accessed November 10, 2009).
} 
sweetened the medicine. Keith Butler, one of Rhema's first graduates, built Detroit's Word of Faith Christian Center from a pocket-sized congregation to a megachurch so large that he took the title of Bishop. Newcomers like Tommy Barnett, Rod Parsley, Charles Niehman, and Mac Hammond also established congregations during this wave of church planting. Though Tulsa remained the institutional heartland, Faith churches spread widely across the suburban Midwest and Sun Belt regions.

Even before the golden years of televangelism, the spread and uniformity of Faith teaching owed much to television. Prosperity preachers joined the spiking number of syndicated programs (those appearing on five or more stations), appearing on more stations with greater frequency. Technological developments eased the cost and speed of television production and allowed programs to broadcast simultaneously, blanketing the airwaves with an increasingly familiar message of prosperity. ${ }^{104}$ Faith teachers like Oral Roberts, Robert Schuller, and Rex Humbard, reigned as the leading lights of inspirational television, gradually displacing Roman Catholic, mainline, and even denominational evangelical shows as the most-watched religious programs. ${ }^{105}$ In 1971 , a cluster of independent preachers (predominately prosperity folk) comprised 42 percent of the top syndicated religious programs on television. In 1981, the total jumped to 83 percent. It effectively narrowed the scope of religious broadcasting, affording the Faith gospel a market-share that came close to a theological monopoly. ${ }^{106}$ Flipping from channel to channel on Sunday morning, viewers might worry that they were watching endless reruns.

\footnotetext{
104 Technological advances lowered the high production and circulation costs of television broadcasting, as videocassette taping allowed rapid distribution and the ability to televise the same program simultaneously across the country. Jeffrey K. Hadden, "Religious Broadcasting," The New Encyclopedia of Southern Culture, vol. one (Chapel Hill, NC: University of North Carolina Press, 2006), 42.

105 Jimmy Swaggart's Jimmy Swaggart, Richard De Haan's Day of Discovery, Jerry Falwell's Old Time Gospel Hour, the Paulist Fathers' Insight, the Bakkers' PTL Club, and Pat Robertson's The 700 Club rounded out the top ten. See Peter G. Horsfield, Religious Television: The American Experience (New York: Longman Inc., 1984), 103-104.

${ }^{106}$ Horsfield, Religious Television, 88-100.
} 
Religious television transported the drama of tent revivalism to American living rooms. "In a sense," noted the historian Edith Blumhofer, "deliverance evangelism never died; rather, it remade itself into the electronic church." ${ }^{107}$ A. A. Allen, Kenneth Copeland, and Morris Cerullo's television programs continued to earn respectable ratings and nationwide exposure. ${ }^{108}$ The possibilities seemed limitless. In 1970, Rex Humbard's broadcast, "The Cathedral of Tomorrow," shot on location in his multimillion dollar megachurch of the same name, appeared on more television stations "than any other American program." ${ }^{109}$ Twenty-five million people watched Oral Roberts's 1975 Thanksgiving television special. By the decade's end, American religious broadcasting earned an estimated $\$ 1$ billion in total revenue. ${ }^{110}$ Faith ministers did not simply add to television programming: they transformed it.

The 1970s saw an explosion of Christian television as a host of innovators founded television networks that soon became electronic empires. Pat Robertson's Christian Broadcasting Network (CBN) built up its fledgling enterprise with popular programs like The $700 \mathrm{Club}$ and The Jim and Tammy Show, featuring the young Jim and Tammy Faye Bakker. From 1970 to 1975, their estimated viewership climbed from 10 to 110 million. ${ }^{111} \mathrm{CBN}$ quickly distinguished itself as one of the most important networks in the industry for its pioneering use of satellite technology and 24-hour programming. In 1973, Paul and Jan Crouch founded Trinity Broadcasting Network, a sprawling enterprise that, within a few short years, acquired Lester Sumrall's modest television network. ${ }^{112}$ Not to be outdone, the Bakkers founded the PTL Television Network to

\footnotetext{
107 Edith Blumhofer, Restoring the Faith: The Assemblies of God, Pentecostalism, and American Culture (Urbana: University of Illinois Press, 1993), 217.

${ }_{108}$ Harrell, All Things Are Possible, 45.

109 Gordon Melton, "Rex Humbard," in Religious Leaders of America: A Biographical Guide to Founders and Leaders of Religious Bodies, Churches, and Spiritual Groups in North America (Detroit, MI: Gale Research, 1999), 263.

${ }^{110}$ Hadden, "Religious Broadcasting," 41.

111 Harrell, Pat Robertson, 59.

112 See Fred Lilly, "Lester Sumrall: Cathedral of Praise," Charisma, November 1985, 48-52.
} 
become two of televangelism's brightest stars. With Faith teachers at the helm of expansive television enterprises, they effectively seated hundreds of thousands of new audience members before the newly formed movement.

In the early 1980s, Faith leaders surveyed the charismatic landscape with satisfaction. Once a tent-toting assembly of independent revivalists, Faith teachers stood at the helm of the sprawling movement that remade much of Pentecostalism. To be sure, many traditional Pentecostals maintained their distance from the Faith movement. The Assemblies of God, for example, looked askance at Faith teachers within their fold, as ministers like Karl Strader and Jim Bakker, tested the tolerance of denominational bounds. The leading Assemblies of God evangelist, Jimmy Swaggart, publicly denounced them as more "charismatic" than "Pentecostal" for their prosperity leanings. "Pentecostals and charismatics are two different worlds, " he declared. "It is my feeling they should be one way or the other." 113

Most overlooked the rift between the two, if they saw it as such, while supporters protested that their gospel was simply that old-time religion. "Pentecostal historians have told me that the very same things my father teaches today were taught by the pioneers and founders of the Pentecostal movement, and I know this is so," said Kenneth W. Hagin Jr., who called his father's work a "distillation of all that was good in the great movements in the past." ${ }^{114}$ The purified truth centered on faith, the unseen force that turned the spoken word into reality. With the structures of the movement firmly established, secured by educational, ministerial, and promotional platforms, followers set out to convince subsequent generations that "without faith it is impossible to please God" (Hebrews 11:6). As the ranks of the faith-filled ballooned, believers smiled at the newfound prosperity of their homegrown gospel.

\footnotetext{
${ }^{113}$ Unknown author, “New Role for Swaggart?" Charisma, June 1987, 60.

${ }^{114}$ Hagin, “Trend Toward Faith Movement," Charisma, August 1985, 67-70. 101
} 


\section{Chapter Three: Wealth}

JEHGVAH JIREH (MY PRQVIDER)

Televangelists Jim and Tammy Faye Bakker needed to look no further than their own backyard to see how far the prosperity gospel had come. By the mid-1980s, their 2,200-acre Christian resort and theme park called Heritage USA had transformed the South Carolina landmark into the nation's third most-visited attraction. Tourists could wander from the pricey Heritage Grand Mansion, vacation houses, and restaurants to the roller rink, sprawling water park, and family-friendly campgrounds. It was a Christian playground for believers, who, flushed with their own successes, caught the vision of the charismatic couple who made the abundant life seem possible. The Bakkers presided over the electric church as television royalty, attracting audiences with their campy banter and theatrical delivery. Their high-roller lifestyle-complete with mansion, designer apparel, and twin Mercedes cars-made the couple national icons of the billion-dollar televangelism industry and living examples of the power of faith to produce results. Successful and controversial, Tammy and Jim, an Assemblies of God preacher, validated the financial heights to which Pentecostals had climbed and invited the rest to join the action. "The gospel to the poor," concluded the one-time professional singer Kenneth Copeland, "is that Jesus has come and they don't have to be poor anymore!" 1

The most controversial aspect of the movement is its radical claim to transform invisible Faith into financial rewards. Its prophets proclaimed a palpable gospel, one that proponents could measure in the financial well-being of its participants and seen as

\footnotetext{
${ }^{1}$ Kenneth Copeland, Poverty: The Choice is Yours (Fort Worth: Kenneth Copeland Publications, 1985), 10.
} 
plain as day. We miss an important part of the story if we detach divine finance from the larger promise of demonstrable Faith. ${ }^{2}$ Believers accepted what the theologian Miroslav Volf dubbed the materiality of salvation. Historically, Pentecostals set themselves apart by their expectation that "signs and wonders" accompanied evangelism as anticipations of God's reign. Authentic Christianity bore witness to itself not only by the truth of its teachings but also by the supernatural trail following in its wake. The prosperity gospel elaborated on this doctrine by teaching that these wonders manifested themselves in the lives of every individual, and that Faith-filled individuals should expect signs and wonders in their lives as evidence of the truth of their convictions. Further, financial abundance and good health (the subject of the next chapter) stood as public and perpetual demonstrations of Christians' spiritual progress. What Faith teachers embraced as a fuller realization of Christ's coming kingdom lent the message an empirical character as insiders sought to experience a measurable Faith.

This chapter traces how believers calculated Faith by their personal finances, making material reality the measure of success for immaterial Faith. We examine how followers sought a God of abundance in Scripture, in the example of leaders, but most often, in the twists and turns of their own lives. Prosperity was a gospel of weights and measures. As preachers heaped promise after promise of monetary gain, their claims led supporters to seek out scales by which to weigh their own rewards.

\section{Jehovah Jireh}

To followers of the prosperity gospel, God revealed himself as Jehovah Jireh, God the Provider. God lavished believers not only with spiritual virtues but also the material

\footnotetext{
${ }^{2}$ Believers understood prosperity and health as two sides of the same coin. Gloria Copeland marveled that she "had been looking at finances and prosperity in a different way from other things, such as divine health...If a symptom of sickness came on my body, I would not stand for it. ...You should refuse lack just as quickly as you refuse sickness." Gloria Copeland, "God Wants You to Prosper, As Your Soul Prospers," Charisma, September 1980, 38-41.
} 
comforts that lightened the load of everyday living. "The Lord shall provide all my needs," ran the lyrics of Benny Hinn's favored crusade anthem, "Jehovah Jireh takes care of me." ${ }^{3}$ The Christian way offered more than subsistence living. Tradition-bound Christians scraped by with barely enough, they reasoned, while true believers drilled deeper to tap into the abundant lives that God promised. "He is Jehovah-Jireh," explained Ohio evangelist Rod Parsley, "the God of more than enough. He gives us the ability to plant, to harvest, and to gather the abundance into the storehouse." ${ }^{4}$ Everyone possessed the God-given potential to sow and reap their financial harvest with plenty to spare. Poverty marked a spiritual shortage. Faith believers claimed the promise from Jesus' lips that he came "that they might have life, and that they might have it more abundantly." ${ }^{5}$ Outsiders called it baptized materialism. Followers called it living in the overflow.

Three arguments grounded the movement's defense of biblical wealth. First, prosperity theology turned to the cross as the solution to all human needs. Jesus' death and resurrection abolished not only sin and disease, but also poverty. In order to understand this financial provision of the atonement, we must recall the movement's priority on spirit. Poverty took on spiritual proportions as a demonic force that separated people from their godly inheritance. Poverty—as an evil spirit—required a spiritual solution. Jesus reclaimed dominion over the earth from Satan when he took on the spiritual debt of poverty on the cross. "He took your place in poverty," argued the African American pastor Leroy Thompson of Word of Life Christian Center in Darrow, Louisiana, "so you could take His place in prosperity." ${ }^{6}$ As a result, believers could claim

\footnotetext{
3 Terry Winch, “Jehovah Jireh,” EMI Christian Music Publishing, 1978. According to Genesis 22:14, Jehovah Jireh referred to the place where God provided a ram for Abraham to sacrifice instead of his son Isaac.

${ }^{4}$ Rod Parsley, Daily Breakthrough: Daily Devotions to Take You Into God's Promise (Orlando: Charisma House, 1998), 295.

${ }^{5}$ John 10:10 (KJV)

${ }^{6}$ Leroy Thompson Sr., Money Cometh to the Body of Christ (Tulsa: Harrison House, 1999), 250.
} 
wealth as one of their rights and privileges in Jesus' name. Teachers struggled to explain wealth as easily as they did health. Jesus' gruesome crucifixion tied the atonement to suffering as a corollary of sickness, but there was no moment teachers could point to that signaled Christ's defeat over poverty. Only those who specialized in divine finance approached the subject with much gusto. Pastor Thompson described Jesus' resurrection as the moment when "He couldn't stand being broke any longer! He came up on the third day! He said, in effect, 'Enough of this!'”7 Jesus rose from the grave as the redeemer of poverty's curse. $^{8}$

Second, believers argued that they followed in the Master's steps. Jesus himself possessed great wealth, and it followed that his devotees should also. Snippets from Jesus' life offered a few clues. "As soon as Jesus arrived, that anointing to prosper acted like a magnet, drawing wise men with gifts of gold, frankincense, and myrrh," argued World Changers Church pastor Creflo Dollar. "Those were not cheap gifts, either. Prosperity attached itself to baby Jesus immediately, and that same gift to prosper has been given to us as heirs of Christ." ${ }^{9}$ That the guards divided Jesus' cloak among them at his crucifixion suggested that his belongings were valuable. ${ }^{10}$ Heart of a Billionaire author Thomas Anderson, pastor of the Living Word Bible Church in Mesa Arizona, counted Mary and Joseph's donkey ride to Bethlehem as proof of their wealth, because the

\footnotetext{
7 Ibid.

${ }^{8}$ As ever, Kenneth E. Hagin taught the movement's basic position: "Jesus become poor materially for us. He was our Substitute." Kenneth E. Hagin, The Biblical Keys to Financial Prosperity (Tulsa: Kenneth Hagin Ministries, 2005), 19. See also Oral Roberts, How I Learned Jesus Was Not Poor (Altamonte Springs, FL: Creation House, 1989).

${ }^{9}$ Creflo Dollar Jr., Total Life Prosperity: 14 Practical Steps to Receiving God's Full Blessing, (Nashville: Thomas Nelson Publishers, 1999), 15. Some Faith teachers rebutted this line of reasoning. See James Robison, True Prosperity: Truth Matters (Carol Stream, IL: Tyndale House: 2004), 44.

${ }^{10}$ See also Julie Chrystyn, The Secret to Life Transformation: How to Claim Your Destiny Now! (Beverly Hills: Dove Books, 2009), 67; Thompson, Money, 247. For the most detailed treatment of Jesus' wealth, see Kenneth E. Hagin, The Midas Touch (Tulsa: Kenneth Hagin Ministries, 2000), 42-65.
} 
animal was the contemporary equivalent of a Cadillac. ${ }^{11}$ Though examples of righteous people of wealth sprang more readily from the pages of the Old Testament, teachers continued to scour Jesus' life for signs that he had paved the way for prosperous living.

Third, believers rooted prosperity in covenant theology as an extension of the ancient promises God made to Abraham. ${ }^{12}$ Favor and riches sprang from faithfulness to the Abrahamic Covenant. "In the Old Testament, according to Deuteronomy," Kenneth Hagin explained, "poverty was to come upon God's people if they disobeyed Him."13 The scriptures were shot through with the Deuteronomic imperative that blessings accompanied the keeping of the Law (and curses heralded its disobedience). Pre-Fall humanity once enjoyed unimpeded access to wealth in the Garden of Eden, "when He surrounded Adam and Eve with every material blessing they could possibly need." ${ }^{14}$ Their sin transferred legal dominion of the earth to Satan, who kept humanity in want of health, provision, and God's power. Jesus' death and resurrection flooded the world with new victory and financial reminders of believers' redeemed status as God's children. As the gospel-singer Donald Lawrence sang in "Back to Eden": "Our families blessed; finances blessed / Our mind and spirit; our bodies blessed / We were tempted and we fell / Jesus came now all is well." The saints claimed a rich inheritance as their own.

Yet the defense of wealth did not end there. Teachers and believers alike moved quickly past theological exposition to testimonies that quickened their pulses and enlivened their spirits. The faithful wanted to hear from those who only looked

\footnotetext{
${ }^{11}$ Rich God, Poor God author John Avanzini detailed Jesus' designer clothes and expensive anointing oils as further evidence. Some argued that Jesus lived a wealthy life but defeated poverty on the cross, while others seemed to be content that Jesus' lifetime of poverty was part of his messianic purpose. For one of many lists of Jesus' wealth, see John Avanzini, The Wealth of the World: The Proven Wealth Transfer System (Tulsa:

Harrison House, 1989), 81-86.

${ }_{12}$ God promised the land as an everlasting possession, numerous progeny, and a special relationship between God and the descendants of Abraham and Sarah (Genesis 17:7-8).

${ }^{13}$ Hagin, Biblical Keys, 18, 26,

${ }^{14}$ Kenneth and Gloria Copeland, Prosperity Promises (Tulsa: Kenneth Copeland Ministries, 1997), vi. See also Hagin, Biblical Keys, 45-68.
} 
backwards long enough to see God's hand at work.

\section{Megaministry}

In 1983, the Bakkers opened their Praise The Lord television studio at Heritage USA to fanfare and a personal note from the equally sunny President Ronald Reagan, who congratulated the duo on their efforts to help "many Americans endure and triumph." ${ }^{15}$ Indeed, many Americans felt triumphant during the decade's prolonged economic expansion, fitted with a market-oriented economy and an ethic of excess memorialized in the film Wall Street as "greed is good." The galloping optimism and individualism that famously made it morning again in America suited well the Faith movement's decade of growth.

Ministry took on larger-than-life proportions. Celebrities like Jimmy Swaggart, the Bakkers, and the Crouches commanded multimillion-dollar media conglomerates supported by hundreds of thousands of viewers. Oral Roberts alone commanded an annual budget of $\$ 125$ million. ${ }^{16}$ A 1985 Charisma poll tapped Pat Robertson, Kenneth Copeland, and Kenneth Hagin as the three most influential leaders in the charismatic community. ${ }^{17}$ Megachurches loomed large on the religious landscape as the innovative centers of revival. In 1970, fifty megachurches dotted the map. By 1990, the total swelled to 310. Of these, Faith congregations numbered roughly 35, a modest but vital minority. Most sprung up and flourished in the 1980s and 1990s, comparatively late bloomers in the church growth movement that believed that bigger was better. The broader conservative Christian culture seemed convinced, including fundamentalist,

\footnotetext{
${ }_{15}^{15}$ James A. Albert, Jim Bakker: Miscarriage of Justice? (Chicago: Carus Publishing, 1998), 108.

16 Stephen Strang, "Oral Roberts Shares His Heart," Charisma, June 1985, 56.

17 Stephen Strang, "Who Are the Most Influential Leaders in the Charismatic Renewal?" Charisma, August $1985,110-116$.
} 
charismatic, Vineyard, Pentecostal, and evangelical camps. Frederick Price spoke for them all when he stated candidly: "Every church should be a big church." 18

The scale of prosperity churches owed much to the success of the church growth strategies promoted during the 1970s, 1980s, and 1990s by a host of conservative Christian pastors and academics who argued that the "traditional church" could not reach the unsaved with its existing structures. ${ }^{19}$ Growth experts targeted Baby Boomers as spiritual wanderers whose comfort in big box establishments-university classrooms, corporate cubicles, and Wal-Mart aisles-predisposed them to church models that resembled these large institutional forms. Strategists hoped to make contemporary churchgoing feel as comfortable as trips to the mall. Continuing in this commercial vein, experts recommended that churches implement marketing strategies and view their church as a product and their worshippers as consumers. As populations drifted from city centers to the suburbs, and later to "edge cities" growing near metropolitan hubs, pastors and congregations built sprawling church campuses near freeways and interstates, hoping to capture the largest market share. Each congregation tailored their product to capitalize on their target audience, demographic preferences, and selling features. ${ }^{20}$ Non-denominational evangelical churches that adopted market-driven features to make their services visitor-friendly won recognition as "seeker sensitive" churches. ${ }^{21}$

\footnotetext{
${ }^{18}$ Anne C. Loveland and Otis B. Wheeler, From Meetinghouse to Megachurch: A Material and Cultural History (Columbia: University of Missouri Press, 2003), 127.

${ }_{19}$ Experts argued that large churches offered the educational, recreational, social services necessary to meet the needs of the urban landscape. Loveland and Wheeler, From Meetinghouse to Megachurch, 114-117. See also Thumma and Travis, Beyond Megachurch Myths, 14-15.

${ }^{20}$ Loveland and Wheeler, From Meetinghouse to Megachurch, 114-120.

${ }^{21}$ Bill Hybels and Willow Creek Community Church in South Barrington, Illinois, served as the prototype of seeker-sensitive churches, with its pared-down Christian vocabulary, business casual dress, and corporate architecture. Loveland and Wheeler, From Meetinghouse to Megachurch, 127.
} 
The California televangelist Robert H. Schuller, prosperity preacher and a churchgrowth guru, led by example. ${ }^{22}$ Ordained in the Reformed Church in America like his positive thinking predecessor Norman Vincent Peale, Schuller exhibited an early flair for advertising and church growth. For example, when he could not find property for his church-plant in Garden Grove, California, he rented a drive-in theatre and preached to the fifty assembled cars while perched on the roof of the refreshment stand. His advertising jingle said it all: "Come as you are in a family car." Drive-in church services (later with sermons piped in through the car radio) remained a fixture of his ministry and a tribute to his interest in making religion appealing to the unchurched. This consumerist model paid off handsomely, allowing Schuller to pursue a vastly expensive building project dubbed the Crystal Cathedral, a church of glass large enough to house a river. The Tower of Hope, with a ninety-foot glowing cross, soon followed. Schuller's expansive vision won the day. His church ministry sprawled, including a school, retirement home, call center, and local outreach programs. He topped the New York Times bestseller list with a reconfiguration of "positive thinking" into "possibility thinking." His books, which included Move Ahead with Possibility Thinking (1967), Peace of Mind through Possibility Thinking (1977), Self-Esteem: The New Reformation (1982), Tough Times Never Last But Tough People Do (1983), and The Be Happy Attitudes (1985), established Schuller as the self-help authority of his generation. He founded the Robert H. Schuller Institute for Successful Church Leadership to show others the path he had trod.

Faith megachurches embodied the entrepreneurial logic of this movement to the utmost, and included the corporate models that seeker-sensitive megachurches were willing to employ in both theology and practice. Faith megachurches minimized

\footnotetext{
${ }^{22}$ Robert Schuller, Your Church Has Real Possibilities! (Glendale, CA: Regal Books, 1974).
} 
"churchlike" features such as crosses, steeples, or stained glass in favor of the bricks, steel, and glass of a corporate headquarters. Predominantly white prosperity churches with strong evangelical connections cultivated the atmosphere of an unbuttoned workplace. Women and men could forgo dressy Sunday fashion in favor of the attire of the workplace "casual Fridays." In contrast, African American megachurch fashion tilted in the opposite direction, as suits, ties, and women's wide-brimmed hats indicated personal wealth. ${ }^{23}$ Yet the same logic prevailed: for Faith worshippers there was never a clear distinction between church and the marketplace. Senior pastors took on the title Chief Executive Officer (CEO), frequently splitting their ministries into "for profit" and "not for profit" branches. Successful pastors considered themselves true entrepreneurs, arguing that kingdom principles were, in fact, business principles. ${ }^{24}$ They called it kingdom business.

Yet megachurches were not the only establishments that experienced and promoted prosperity. ${ }^{25}$ Religious television proved to be one of the 1980 s most obvious signs of economic expansion and the seemingly unlimited frontiers of ministry.

\section{Televangelism}

Prosperity televangelists ruled the decade as stars of the small screen. The "Electronic Church" ballooned from 5 million in the late 1960s to 25 million by the mid1980s, giving numerous Faith teachers top-billing in living rooms across the country. In

\footnotetext{
${ }^{23}$ Historically, African American churchgoers have dressed up more than their white counterparts have. See Shane White and Graham White, Stylin': African American Expressive Culture, from Its Beginnings to the Zoot Suit (Cornell University Press, 1999). Prosperity churches' theology of demonstrative wealth amplified the importance of such practices.

${ }^{24}$ See Miles Munroe, Kingdom Principles: Preparing the Kingdom Experience and Expansion (Shippensburg, PA: Destiny Image Publishers, 2006).

${ }^{25}$ Megachurches and televangelism certainly reached different (though overlapping) populations. Megachurches culled from surrounding areas, while approximately half of religious television viewers came from the South. The Midwest constituted 25 percent of viewers. Two thirds to three quarters of all viewership was over fifty and predominately female. See Jeffrey K. Hadden, "The Rise and Fall of American Televangelism," Annals of the American Academy of Political and Social Science, vol. 527, Religion in the Nineties (May 1993), 43.
} 
1983, Jimmy Swaggart, Oral Roberts, Robert Schuller, and Rex Humbard were the mostwatched of the religious programs nationwide. ${ }^{26}$ Schuller's television program, The Hour of Power, re-packaged the church's worship services for mass viewing, an unlikely idea that by 1983 garnered 2.5 million viewers. ${ }^{27}$ Three religious networks— the Bakkers' Praise the Lord (PTL), the Crouch's Trinity Broadcasting Network (TBN), and Robertson's Christian Broadcasting Network (CBN)_pumped out religious programming 24 hours a day, seven days a week. ${ }^{28}$ As these stations could produce no more than a few hours of programming per day, they desperately needed programs to fill the time. This offered a golden opportunity for up-and-comers to gain exposure, albeit for small audiences. The sociologist Jeffrey Hadden noted that "for a while, almost anyone who could produce a videotaped program could send it to one of these new networks and be accepted for satellite broadcast." ${ }^{29}$ The focus on money that characterized the televangelist decade owed some of its reputation to these cowboy preachers who jockeyed for attention with their low budget shows saturating the airwaves.

Through the 1980s prosperity preachers squeezed television for every last emotional drop. ${ }^{30}$ The frequent use of direct appeals to the camera-teaching, arguing, cajoling, or even pleading with at-home audiences—-defined the era as the high drama of tent revivalism was brought to prime time television. Emotion ebbed and flowed through

\footnotetext{
${ }^{26}$ Jimmy Swaggart renounced prosperity theology in 1981. He actively campaigned against fellow prosperity preachers in the Assemblies of God until his own downfall in 1988, taking aim in particular at Jim Bakker, Bishop Earl Paulk, and the Rev. Karl Strader. Unknown author, "New Role for Swaggart?" Charisma, June 1987,60 .

${ }^{27}$ The 1980s televangelists borrowed time-tested techniques. From 1957, Billy Graham broadcast his crusades to vast audiences.

${ }^{28}$ These networks catered to a wider audience than the Faith movement, featuring teaching programs with evangelical favorites like Hal Lindsey, and Tim and Beverley LaHaye, as well as Faith celebrities like Lester Sumrall and Marilyn Hickey.

${ }^{29}$ Jeffrey Hadden, "Religious Broadcasting," The New Encyclopedia of Southern Culture, vol. one (Chapel Hill, NC: University of North Carolina Press, 2006), 41-42. Once established, many decided to forego satellite for the larger market of television syndication.

${ }^{30}$ Mainline Protestant fundraising efforts eschewed emotion for organization. In the late 1970s and 1980s, mainline congregations took an institutional approach with annual pledges and efforts to urge members to add the church to their wills. James David Hudnut-Beumler, In Pursuit of the Almighty's Dollar: A History of Money and American Protestantism (Chapel Hill, NC: University of North Carolina Press, 2007), 186.
} 
every broadcast, and, for those who taped their programs before live audiences, the masterful learned to ride the current. Yet nothing tested the financial resolve of viewers (and the mettle of leaders) like telethons. Their marathon programming was a feat of organization and improvisation as preachers scrambled to fill the time with education, entertainment, and financial pleas. In 1965, Michigan native Jim Bakker made fundraising history when the fledgling CBN failed to meet its telethon goal and Bakker burst into tears. The boards lit up with incoming calls, flooding the station with pledges as viewers frantically responded to his emotional entreaties. ${ }^{31}$ Subsequent telethons tried to duplicate Bakker's magic, with varying results. Close-up camera shots and rollercoaster emotions made telethons the favored fundraising tool of the decade and a perpetual demonstration of the effectiveness of sentimentality. Bakker proved to be one of the most successful fundraisers in television history, perennially demonstrating his ability to connect to audiences with his maudlin charm.

Television and prosperity theology were a natural fit, since spiritual programming proved to be not only an effective tool of evangelism, but also of generating income. Outsiders commonly reduced all prosperity theology to fundraising, a merited cliché. Faith televangelists dominated religious programming as masters of persuasion, able to inspire the vast financial donations required to maintain their electric churches. Constant appeals for donations came in many forms. The Bakkers kept a loose lid on their emotions, weeping or rejoicing openly as financial goals were missed or met. ${ }^{32}$ Televangelist and church planter Don Stewart mastered the hard-sell tactics of his predecessor A. A. Allen, promising viewers miraculous returns on their donations. Faith pledges became a fundraising basic with audiences phoning in their promised donation.

\footnotetext{
${ }^{31}$ David Harrell, Pat Robertson: A Personal, Religious, and Political Portrait (San Francisco: Harper \& Row, 1988), 57.

${ }^{32}$ Viewers knew better. A 1980 ethnography of PTL viewers found that even among ardent supporters, observers remained critical of their constant financial requests. Louise Manon Bourgault, An Ethnographic Study of the "Praise the Lord Club," (Ph.D. dissertation, Ohio State University, 1980), 179.
} 
Yet the network's dependence on faith pledges repeatedly left them in the lurch. A Trinity Broadcasting Network telethon went awry when it turned out that a fourth of its pledges had come from prank calls. ${ }^{33}$ Teachers threatened that "unpaid vows" constituted a terrible sin, but they could do little. ${ }^{34}$ They too had to live by faith.

Faith televangelists memorably went to great lengths to cultivate intimacy with their television audiences. Teachers presented themselves foremost as family, inviting viewers into television sets imitating the preacher's own home. Constant declarations by teachers that "I love you ... I pray for you each day" assured viewers that they were known and loved. ${ }^{35}$ Studios trimmed their stages to mirror conventional notions of gender. Male preachers sat at a desk or living room chair with few accessories, while women were perched among flowers arrangements or at the kitchen table itself. Husband and wife teams formed popular duos as spouses referred to one another using first names, often revealing personal information and anecdotes about their married life. Jim and Tammy lived out much of their married life on camera, teasing, flirting, and even arguing before live studio audiences. Children and extended family popped in as extended cast members, introducing viewers to the cast as a family and inviting listeners to be part of the family. The staff of volunteers answering phones in the backdrop of the Bakkers' shows reminded audiences that they were only a call away. The steady stream of footage of listeners' faces mirroring the appropriate emotion further connected the audience to the distant celebrity.

These television stars dressed as wealthy celebrities. The prosperity gospel made small inroads in men's fashion, as celebrity preachers did little more than update their

\footnotetext{
33 Dennis Roberts, “Trinity Broadcasting Network: The Dream Almost Didn't Happen,” Charisma, June 1983, 21.

${ }^{34}$ John Avanzini, It's Not Working, Brother John: 25 Things That Close the Windows of Heaven (Tulsa: Harrison House, 1992), 155-6.

${ }^{35}$ Joyce Meyers, “Enjoying Everyday Life," New Haven, CT: Channel 49, Friday 9:30-10:00, November 26,' 2004.
} 
designer apparel with the thickness of their ties or the length of their hair. The young Jim Bakker made a splash with his gold chains and blue and green suits. Yet in the controversial terrain of women's bodies-especially female preachers' bodies-the prosperity gospel made a lasting impression. Teachers like Tammy Faye Bakker and Jan Crouch became media icons for their conspicuous displays of wealth, earning them the constant criticism (or shy admiration) of viewing audiences for their "worldliness." Their radical departure from Pentecostal-Holiness standards of dress disgruntled traditional Pentecostal supporters. Tammy Bakker, in particular, faced constant opprobrium for her heavy mascara, blond bouffant, and country-girl sex appeal. "Painted hussy, that's all I can see, like Jezebel," huffed an elderly male viewer. ${ }^{36}$ But when Tammy Faye peeked out at the camera from under her white fur hat, she embodied (as well as sang) the title of her musical album: We're Blest. ${ }^{37}$

\section{Hard Prosperity}

The surprising gains of prosperity theology in pulpits, publications, conferences, and television airtime strengthened its leaders' resolve to raise their ministries to everincreasing heights. Teachers, invigorated by constant growth, confidently confessed brighter futures. They concluded that nature yielded to the proper use of divine principles. Mechanistic accounts of giving and receiving dominated. ${ }^{38}$ Faith teachers differed on their interpretations on the exact relationship between the spoken word and its coming-into-being. This was a decade of hard prosperity.

"Hard prosperity" drew a straight line between life circumstances and a believer's Faith. Faith operated as a perfect law, and any irregularities meant that the believer did not play by the rules. Charles Capps stood as one hard prosperity preacher

\footnotetext{
${ }^{36}$ Bourgault, An Ethnographic Study, 165-166, 184.

${ }^{37}$ Tammy Faye Bakker, We're Blest, PTL Records, 1979.

${ }^{38}$ Kenneth E. Hagin later bemoaned it as an attempt to "make the offering plate some kind of heavenly vending machine." Hagin, The Midas Touch, 140.
} 
among many. Capps, an ordained minister and popular guest on Gloria and Kenneth Copeland's television program, systematized Faith theology into an iron clad system of causality. The spoken word, by activating Faith, bound God to the individual's proclamation. When the one-time farmer built a housing subdivision north of England, Arkansas, he took on a mountain of debt to finance his project. Convinced that Faith could remedy the situation, he arranged the numerous mortgages for the development properties on the kitchen table. "Notes," he said, "listen to me. I'm talking to you. Jesus said you would obey me. In the name of the Lord Jesus Christ, I command you, I say to you, BE PAID IN FULL . . . DEMATERIALIZE . . . DEPART . . . BE GONE . . IN JESUS' NAME, YOU WILL OBEY ME!" ${ }^{39}$ When asked if this seemed “silly," Capps confidently asserted that the Bible was more practical than believers realized. After all, the proof of the pudding is in the eating: the mortgages were paid, the properties sold, and his subdivision became a success. Capps' major work, The Tongue: A Creative Force, sold more than three million copies. ${ }^{40}$

Hard prosperity hammered giving and receiving into rigid rules. First, pay tithes. Though all Faith teachers preached about the significance of tithing, hard prosperity found God in the details. Creflo Dollar's World Changers Church, for instance, kept detailed financial reports on their members, even asking them to submit tax records to verify that members paid their full tithes. Finance teacher John Avanzini spoke for all when he cited failure to tithe as the primary reason that God failed to return money to believers. Second, hard prosperity made financial miracles an everyday prospect. Positive confessions tailored to "supernatural debt-cancellation" or blessed billfolds

\footnotetext{
"Charles Capps, The Tongue: A Creative Force (England, AR: Capps Publishing, 1976), 27-28.

${ }^{40}$ Capps Ministries Web site, http: / / charlescapps.com (accessed November 9, 2009).
} 
that automatically multiplied its contents, arrived in believers' mailboxes. ${ }^{41}$ Testimonies of sudden infusions of cash dominated the discussion. Third, the process was largely epistemic. "Proper thinking produces finances," Avanzini stated simply. ${ }^{42}$ Positive confession seemed so powerful that considerable debate arose within the Faith movement about the degree to which anyone could use it, regardless of holiness. More than a few suggested that perhaps wealthy people unconsciously lived out the truth. The First Lady of Victorious Faith Church (VFC) in Durham, North Carolina argued that anyone could tap into it without personal faith, as she had once begun "naming it and claiming it" before she understood its implications. The finer theological points mattered less than the conclusion: divine wealth came with an easy trigger.

Prophets of hard prosperity often claimed a specific anointing for financial matters, proffering their ministries as divine vessels through which believers might reap fiscal rewards. ${ }^{43} \mathrm{Jim}$ Bakker credited his anointing as a flash of revelation:

From the moment that I stepped before a television camera at CBN God began to anoint me to raise money for Christian television. I realized it the night I wept

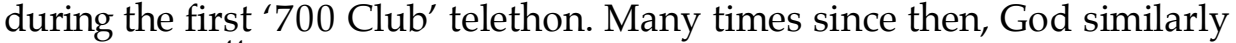
anointed me. ${ }^{44}$

By the late 1990s, the practice of claiming a financial anointing fell out of use. This is not to say that preachers did not urge believers to give in order to receive God's blessings. Yet they did refrain from naming their own ministries as the rightful recipients of God's money.

Formulas for wealth grew increasingly precise. Tithes alone did not guarantee that the windows of heaven stayed open. By the 1980s, the doctrine of "first fruits" became

\footnotetext{
${ }^{41}$ Harrison, Righteous Riches, 4. Hagin, The Midas Touch, 173; Don Basham, Lead Us Not Into Temptation (Old Tappan, NJ: Chosen Books, 1986), 108.

${ }^{42}$ Avanzini, It's Not Working, 145.

${ }^{43}$ See Kenneth R. Sesley, Firstfruits: God's Plan to Propel You from Poverty to Prosperity! (Longwood, FL: Xulon Press, 2009), vii.

${ }^{44}$ Patrick Allitt, Religion in America Since 1945 (New York: Columbia University Press, 2003), 192.
} 
a standard classification of donation, second only to tithes. "Plant your FIRSTfruits in the needs of God's work," read the headline of T. L. Osborn's Faith Digest, "EXPECT His ABUNDANT RETURNS for your own needs." ${ }^{45}$ Donors must cull a portion from the first of every new piece of income. "It's the best of the first," summarized Creflo Dollar. For example, the person who receives a $\$ 50$ raise must donate the first $\$ 50$ to God. ${ }^{46}$ Positive confessors began to affix their tithes and offerings with specific wishes, a practice known as "naming your seed." ${ }^{47}$ Some whispered their desires as they placed their envelope in the offertory. Others took it a step further, taking pains to inscribe the donation itself with their confession. VFC members ordered checks printed with Scripture about blessing, or wrote verses in the memo line below. One consultant cleverly wrote, "Money cometh unto you," on the check, hoping that the bank teller would repeat it and positively confess on her behalf. Believers occasionally scribbled their confessions on the dollar bills themselves. One saw automobiles marked as heaven-sent with vanity plates like PRAYED 4 and BLESSED.

The "hundredfold blessing" dated back to the mid-century healing revivals and served as the most common calculus of God's "money-back guarantee." Most preachers estimated at one time or another that God rewarded givers with a hundred times their original donation. ${ }^{48}$ Gloria Copeland, a famous evangelist in her own right, calculated the returns: "You give $\$ 1$ for the Gospel's sake and $\$ 100$ belongs to you; give $\$ 10$ and receive $\$ 1000$; give $\$ 1000$ and receive $\$ 100,000 \ldots$ Give one airplane and receive one

\footnotetext{
45 T. L. Osborn, "Plant your FIRSTfruits," Faith Digest, August 1976, 8-9.

${ }^{46}$ Creflo Dollar, "Making a Change," World Changers Broadcast, streamingfaith.com (accessed November 24, 2004).

${ }_{47}$ "I'm not sure that 'naming your seed' is necessarily scriptural," Kenneth Hagin worried. "It is good to be specific with our faith, but I also believe it's important not to try to restrict the benefits of a particular offering to a specific result." Hagin, The Midas Touch, 143.

${ }^{48}$ For an early example, see Gordon Lindsay, God's Master Key to Prosperity (Dallas: Christ for the Nations, 1959), 46. Frederick Price, Joel Osteen, Kenneth Copeland, Frances Hunter, Marilyn Hickey, and many others promoted the hundredfold blessing.
} 
hundred times the value of the airplane. Give one car and the return would furnish you a lifetime of cars. In short, Mark 10:30 is a very good deal." ${ }^{49}$ Hard prosperity emphasized its contractual nature, describing God as "unable" to multiply back blessings except to those who "give correctly." ${ }^{50}$ The laws of the harvest formed an exact science. Televangelist Jimmy Swaggart defended his own fundraising efforts but decried the hundredfold blessing as "outright fraud." ${ }^{51}$ Kenneth Hagin later repented of his own teaching on the matter: "I no longer tell people to expect the hundredfold return on their offerings. I just stay with what the Word of God says: 'Give and it shall be given unto you; good measure, pressed down, and shaken together, and running over . .' (Luke 6:38). I always claim the 'running over' blessing." ${ }^{52}$ Though other Faith teachers protested that the world could not contain enough to reward everyone with a hundred-fold return, popularity favored the literal-minded.

Money multiplication strategies seemed more credible in light of the broad cultural shifts concerning credit that left Americans with greater faith in an invisible economy. In the mid-1970s, growing inflation and stagnation, dubbed "stagflation," produced a sluggish economy. Unemployment and the price of consumer goods continued to rise. ${ }^{53}$ Credit and debt-previously stigmatized as the mark of moral weakness-became a strategy to cope with soaring inflation. ${ }^{54}$ Consumers who paid for goods on credit cards could expect to pay less in real terms for that item, as inflation devalued the owed sum. Money became increasingly theoretical, as the connection between the value of one's labor and one's income grew increasingly unpredictable. From

\footnotetext{
49 "But he shall receive an hundredfold now in this time, houses, and brethren, and sisters, and mothers, and children, and lands, with persecutions; and in the world to comeeternal life" (Mark 10:30, KJV). Gloria Copeland, God's Will Is Prosperity (Tulsa: Harrison House, 1978), 54.

${ }_{50}$ John Avanzini, The Wealth of the World: The Proven Wealth Transfer System (Tulsa: Harrison House, 1989), 13-14. (Emphasis original)

${ }^{51}$ Jimmy Swaggart, “Clean Up Our Act,” Charisma, November 1982, 25-29.

${ }^{52}$ Hagin, The Midas Touch, 153.

${ }^{53}$ Bruce J. Schulman, The Seventies: The Great Shift in American Culture, Society, and Politics, (New York: The Free Press, 2001), 35.

${ }^{54}$ Kelly Boyer Sagert, The 1970s (Westport, CT: Greenwood Press, 2007), 4-5.
} 
the creation of the Visa card in 1973, credit card spending grew at a rate of $\$ 3.5$ billion a year as more shoppers began to put their faith in the value of dollars they did not yet see. These economic conditions boosted consumer confidence in unseen multipliers (or dividers).

The prophets of hard prosperity peered into the End Times and saw a brighter future. Their lives plotted a trajectory of unbroken progress. Texas evangelist John Avanzini promoted an apocalyptic message of "biblical economics" that described an army of saints who "take the wealth of the wicked for the harvesting of the world in these last days!" ${ }^{55}$ God promised to transfer the wealth of the wicked into the bank accounts of the righteous. World evangelism remained the goal but Christian imperialism the means: "God is going to take the silver from the wealthy wicked, and He is going to hand that silver, and the monies of the unsaved bankers, and the oil riches of the Arabs, and the money in the International Monetary Fund-all over to the 'innocent' for the funding of His final endtime harvest!" ${ }^{56}$ Yet believers must first prove themselves worthy. Anticipation reserved for premillennial thinking echoed in their accounts of the Lord scouring the earth for those keeping watch. "The Lord is watching everything we do for Him today," argued Benny Hinn. "He is looking for a people He can trust, for the day will come when true riches will be committed to believers who are faithful. These true riches not only are the invisible power of God but also the coming wealth transfer on earth that will finance the end-time harvest!" ${ }^{57}$ Late in life, the elderly Hagin fretted over the frenzy surrounding end-time wealth transfers. "I think we need to be careful about coveting the world's money," he warned..$^{58}$ Money earned theological value as an eschatological and creational marker of God's intent, proof positive that God set

\footnotetext{
${ }^{55}$ Avanzini, The Wealth of the World, 123.

56 Avanzini, The Wealth of the World, 148.

57 Benny Hinn Ministries, "Prosperity ... Is It Biblical?" http:/ / bennyhinn.com (accessed November 9, 2009).

${ }^{58}$ Hagin, The Midas Touch, 171.
} 
Christians aside for special blessings. Yet the Faith movement treasured their God of details, whose financial formulas and principles ensured that, in the end, God would be both good and fair.

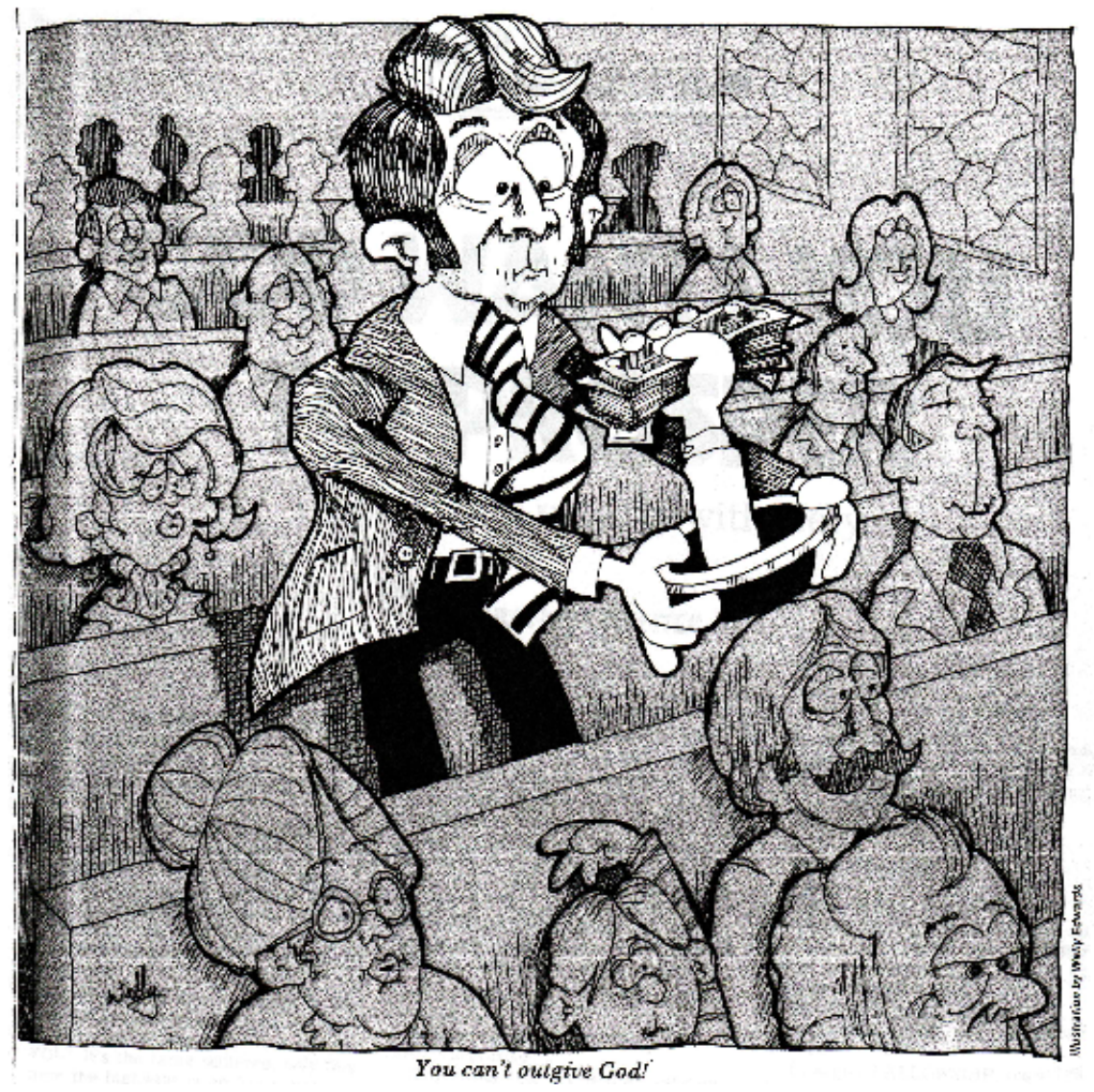

The caption reads: "You can't outgive God!" In this illustration accompanying Charisma magazine's first defense of prosperity, the connection between giving and getting is immediate and undeniable. Wally Edwards, "You Can't Outgive God!" Charisma, June 1978, 15.

\section{Testing Televangelism}

The exponential growth of prosperity TV sputtered in 1987 when a series of scandals tested audiences' faith in its leaders. In February, the City of Faith hospital founder Oral Roberts faced national ridicule when he fell short of his $\$ 8$ million dollar fundraising goal and wrote to followers that he would retreat to Oral Roberts 
University's (ORU) prayer tower to fast and pray until the stated goal was met or "God calls me home." Richard Roberts confirmed his father's dire situation in a follow-up letter, stating that without the funds earmarked for medical missions, "God will not extend Dad's life." ${ }^{59}$ The media decried Roberts's emotional blackmail, while the sympathetic insisted that prophecy was a lonely profession. ${ }^{60}$

The following month the fresh-faced preacher Jim Bakker shocked the nation when reporters revealed that he had committed adultery in 1980 with a 21 -year-old church secretary named Jessica Hahn. The Charlotte Observer broke the news that Bakker used PTL funds as hush money. Rival televangelist Jimmy Swaggart led the charge against his fellow Assemblies of God minister, denouncing him as "a cancer that needed to be excised from the body of Christ." ${ }^{61}$ John Ankerberg, a Christian talk-how host, further accused Bakker of homosexual encounters. Bakker resigned his presidency of PTL and attempted to salvage his faltering empire by giving temporary control to the Old Time Gospel Hour preacher Jerry Falwell. Yet the damage had been done. Shortly thereafter, the Assemblies of God defrocked Bakker for sexual misconduct.

Bakker's trouble had only begun. Falwell discovered the full extent of the Bakkers' financial mismanagement and denounced them in a news conference as unrepentant frauds. ${ }^{62}$ PTL ministries filed for bankruptcy in the firestorm of controversy surrounding the Bakkers' lavish living while the ministry had floundered in debt. Cover stories in Time and Newsweek, to name only two, lambasted the Bakkers' annual salaries and bonuses in excess of a million dollars. In 1989, Jim Bakker stood trial for fraud and conspiracy. A jury convicted him for defrauding viewers by overselling lifetime "partnerships" that entitled members to stay at the Heritage Grand Mansion, raking in

\footnotetext{
${ }^{59}$ Randy Frame, “Fund Raising: Did Oral Roberts Go Too Far?" Christianity Today, February 20, 1987.

${ }^{60}$ Edward C. Stephens, "Oral Tells His Side," Charisma \& Christian Life, November 1987, 70-75.

${ }^{61}$ Joanne Kaufman, “The Fall of Jimmy Swaggart,” People 7, March 1988, 37.

${ }^{62}$ A few years prior, their questionable spending narrowly escaped charges from a Federal Communications Commission investigation of the Bakkers' purchases of a Corvette, mink coat, and 42-foot houseboat.
} 
payment for thousands of time-shares that the property could not accommodate. Long lines of picketers protested the court's mistreatment of Bakker who, they argued, was a man of God. To many insiders, these Faith teachers loomed as spiritual giants beyond reproach because they had transformed believers' lives. Bakker went to prison from 1989 and 1994, during which time Tammy filed for divorce.

To many viewers, the prosperity gospel stood tried and convicted. PTL's downfall exposed the uncomfortable disparity between rich leaders and their followers. The extravagant lifestyle that once testified to Bakkers' piety now sealed their condemnation as reports of their gold-plated bathroom fixtures and air-conditioned doghouses flooded the news. In many ways, the couple's convictions accelerated their downfall. Audiences loved them for their demonstrative faith. Yet the burden of their gospel was it always had to be proven in an endless cycle of bigger-and-better. Only scant days before their disgrace, the debt-plagued ministry broke ground on what was to be the world's largest church, a 1.25-million-square foot complex with a \$100 million price tag. ${ }^{63}$ Heritage USA alone cost an exorbitant amount to build, and Jim's illegal attempts to keep it afloat landed him in deeper waters. As Tammy later reflected, the financial pressure was suffocating. Tammy developed an addiction to anti-anxiety medication, while Jim turned to romantic affairs. They skated the "thin ice of monthly contributions." ${ }^{64}$ Soon they fell through.

At the close of the 1980s, the American televangelist seemed like an unredeemable figure. Audiences dropped from 15.1 million in 1986 to under 10 million. Televangelist Jimmy Swaggart's career fell to pieces when he exposed the adultery of a fellow preacher, Marvin Gorman. Gorman retaliated by producing evidence of Swaggart's own sexual misconduct. The Assemblies of God suspended and defrocked

\footnotetext{
${ }^{63}$ Steven Lawson, “PTL Plans World's Largest Church," Charisma, March 1987, 86.

${ }^{64}$ Jamie Buckingham, "The Press," Charisma, May 1986, 25.
} 
Swaggart. An estimated 100 million people worldwide tuned in to watch Swaggart's tearful apology. ${ }^{65}$ Religious television viewership plummeted as the widespread support for celebrity preachers soured. The grins, tears, and fundraising pleas that had defined the decade no longer won popular support for this upwardly mobile message, and few observers, academic or otherwise, predicted its return. Yet what appeared to be a theological and ethical crisis of confidence had multiple causes.

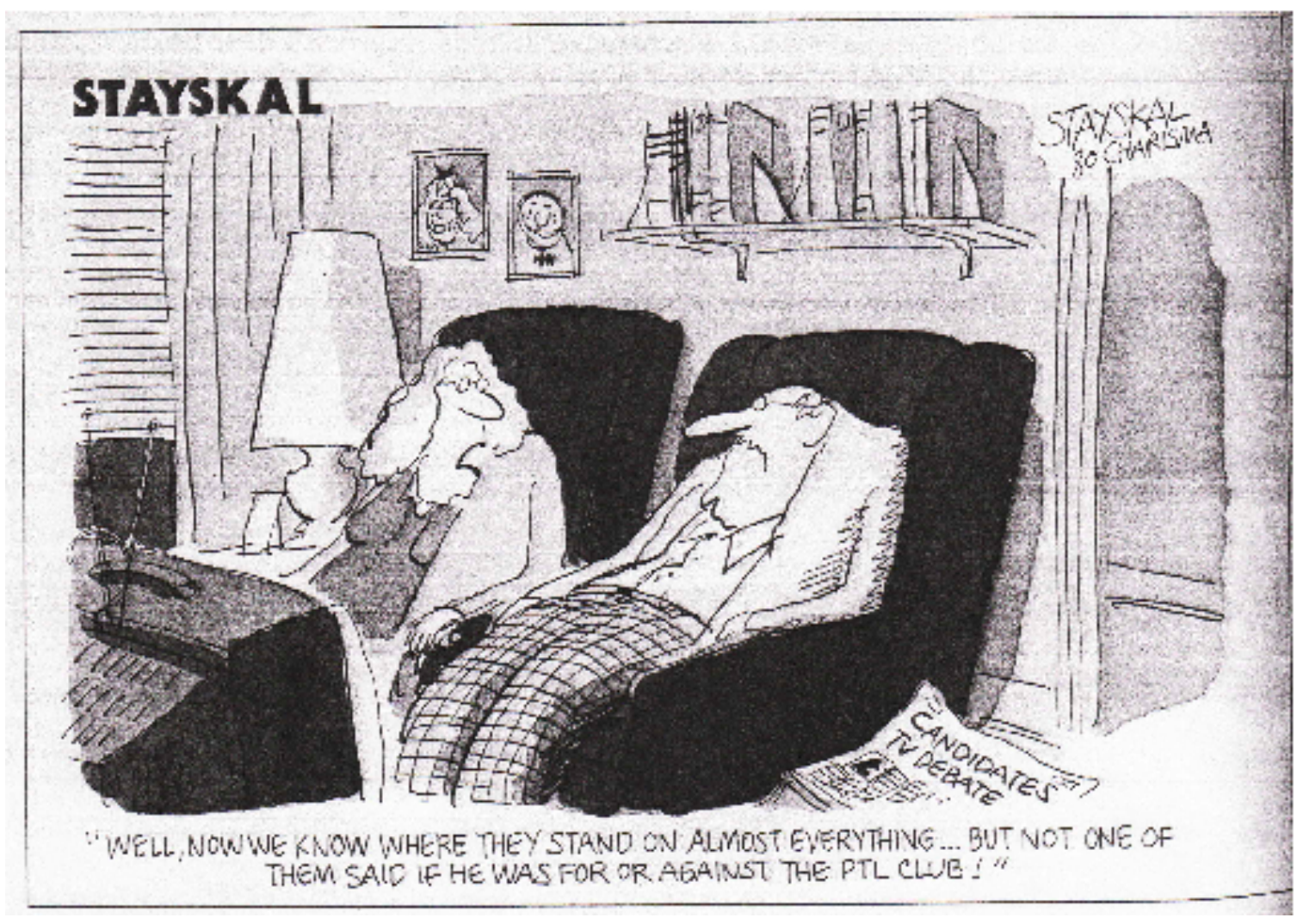

Long before the scandals of 1987, PTL's fundraising practices generated controversy among religious conservatives. Wayne Stayskal, Charisma, May 1980, 32.

The declining viewership of religious television in the late 1980s partly stemmed from market forces. The expanding opportunities that fueled televangelism in the early

\footnotetext{
${ }^{65}$ Swaggart's second lapse after his apology sealed his disrepute. Michael James Giuliano, Thrice-Born: The Rhetorical Comeback of Jimmy Swaggart (Macon, GA: Mercer University Press, 1999), 1.
} 
1980s—from 24-hour religious networks to ballooning television syndication—tapered off by mid-decade, leaving too many big fish in a shrinking pond. The crowd of preachers that had filled up round-the-clock programming now saturated the market, driving up prices for airtime. In 1975, the televangelism pioneer, Rex Humbard, appeared on 175 stations with an average audience of almost 10,000 households per station. Increased competition and airtime costs forced Humbard to cut back, his losses barely mitigated by aggressive mass mailing and telemarketing solicitations. In 1985, the Ohio evangelist had lost 36 percent of his stations. By the year's end, the "Cathedral of Tomorrow" broadcast tumbled off the air. ${ }^{66}$

The disgrace of financial mismanagement continued to haunt Faith networks. Larry Lea, dean of the seminary at Oral Roberts University, called it a "chasm of mistrust. ${ }^{\prime 67}$ Earlier attempts to subject televangelists to financial oversight had failed. The 1979 formation of the Evangelical Council for Financial Accountability (ECFA) had been a much-publicized lame duck. The National Religious Broadcaster's Ethics and Financial Integrity Commission (EFICOM) did little more. Though it expelled Jimmy Swaggart, the commission refused fully to investigate charges brought against TBNfounder Paul Crouch. ${ }^{68}$ That broadcast ministries continued to fill their boards with family members, who, in turn, reaped rewards from the ministry, continued to obscure financial transparency. "God is shaking his church," warned Charisma editor Jamie Buckingham. "Today's shaking is forcing leaders to turn to one another." ${ }^{69}$ Yet not even the scandals could stop televangelists from going it alone, a gamble that ultimately paid off. By the late 1980s, Jan and Paul Crouch's TBN was valued at $\$ 500$ million as the most watched religious network.

\footnotetext{
${ }^{66}$ Hadden, "The Rise and Fall of American Televangelism," 113-130.

${ }^{67}$ Larry Lea, "Why Have Christians Been Holding Back?" Charisma E Christian Life, April 1988, 39-42.

${ }^{68}$ Hadden, "The Rise and Fall of American Televangelism," 113-130.

${ }^{69}$ Jamie Buckingham, "God Is Shaking His Church," Charisma, June 1987, 20-23.
} 
When prosperity teachers returned to the spotlight, the focus changed almost imperceptibly. Figures like Joel Osteen, Joyce Meyer, T. D. Jakes, Creflo Dollar, and Eddie Long came to fame in the cynical religious climate of the 1990s, and replaced garish stereotypes with a new, business-like image. By the mid-1990s, these postmodern prophets would not beg, but rather focused on the returns. They offered "tools" in the form of relationship guides, financial principles, or family reconciliation. The new generation of teachers set aside much of the hard prosperity that had characterized the decade in favor of the therapeutic inspiration of soft prosperity.

\section{Soft Prosperity}

Teachers like Joel Osteen, John Osteen's son and successor at Houston's Lakewood Church, softened the hard causality between the spoken word and reality, representing one major figure of "soft prosperity." Prophets of soft prosperity tied psychological to fiscal success, believing that a rightly ordered mind led to rightly ordered finances. He chose mainstream language over Christian jargon, changing the term "positive confession" to "positive declarations." Yet the principle remained the same: change your words, change your life. He wrote: “Every day, we should make positive declarations over our lives. We should say things such as, 'I am blessed. I am prosperous. I am healthy. I am talented. I am creative. I am wise.'" ${ }^{70}$ For Osteen, the transformative power of positive confession could be demonstrated psychologically, rather than appealing to the forces of Faith. The words build self-image, Osteen taught, for "as those words permeate your heart and mind, and especially your subconscious mind, eventually they will begin to change the way you see yourself." ${ }^{71}$ A healthy mind became an important indicator of good spiritual health and a vibrant conduit of faith.

\footnotetext{
${ }^{70}$ Joel Osteen, Become a Better You: 7 Keys to Improving Your Life Every Day (New York: Free Press, 2007), 109.

Ibid.
} 
Life's circumstances still depended on a believer's use of Faith. Divine wealth eventually came to good people, he reasoned, for a chain of causality-linked thought, the spiritual self, and life's circumstances. "As you speak affirmatively, you will develop a new image on the inside, and things will begin to change in your favor." ${ }^{72}$ God rewarded the faithful with wealth, though believers typically earned it indirectly. Perhaps a careful budget tamed household overspending or the boss noticed the believer's cheerful attitude and tapped them for promotion. "If you'll do your part, God will do His," promised Osteen. "He will promote you; He'll give you increase, but first you must be a good caretaker of what you have." ${ }^{73}$ Promotion and increase arrived as an assortment of ordinary and supernatural opportunities. A believer should simply rely on God's promises of an abundant life. "Call in what God has promised you," Osteen urged readers. ${ }^{74}$

Beginning in the 1970s and 1980s, Faith believers joined the growing number of conservative Christians_charismatics, evangelicals, and Pentecostals among themwho appropriated psychology for Christian uses. ${ }^{75}$ The historian Joseph Williams observed that Pentecostals, and here we might also add Faith believers, adopted psychological categories in a heavily New Thought cast, highlighting the supernatural power of the mind and the spoken word. ${ }^{76}$ As far as Faith proponents were concerned, psychology confirmed what prosperity folks already knew: the mind was a battlefield. Psychological idioms saturated popular Christian literature, as readers learned to speak authoritatively about the role of their subconscious, upbringing, or self-esteem in their spiritual lives. "I grew up with an inferiority complex," began Calvary Assembly pastor

\footnotetext{
${ }^{72}$ Ibid., 115 .

${ }^{73}$ Ibid., 208-209.

74 Ibid., 113.

${ }^{75}$ Joseph Williams, "The Transformation of Pentecostal Healing: 1906-2006” (Ph.D. dissertation, Florida State University, 2008).

${ }^{76}$ Williams, "Pentecostal Healing", 187.
} 
Roy Harthern's testimony about his spiritual turn-around..$^{77}$ A limited range of mental illnesses surfaced as obstacles to be overcome. Few countenanced treatment by a therapist or psychiatrist. For example, Charisma magazine mentioned depression by name, but avoided more complicated disorders like schizophrenia or bipolar. Further, psychological treatments were described as ineffective, if not cruel. In one case, Pauline Harthern's Charisma column testified that she counseled a friend who was terrorized by emotional turmoil that shock therapy and medication had compounded. ${ }^{78}$ Spiritual solutions prevailed. For example, TBN founder Jan Crouch struggled with depression and suicidal thoughts until a miraculous encounter with the laughing Jesus restored her joy. ${ }^{79}$ Psychological labels possessed diagnostic advantages, giving participants insight into the tangled world of thought. "The relationship Christians have with God takes place primarily in the mind," warned TBN's preferred finance teacher John Avanzini. ${ }^{80}$ The relationship between thought and circumstances demanded that Faith teachers become amateur therapists, capable of incisive diagnoses of the spiritual psyche. They borrowed liberally from America's burgeoning therapeutic culture to explain the flow of divine health and wealth into (or out of) people's lives.

The Faith movement's acceptance of psychology, albeit selectively, can also be seen as the late-ripening fruit of positive thinking. Mid-century healing revivalists had shown glimmers of interest in the psychiatry and psychology, though most offered little more than exorcism by way of treatment. ${ }^{81}$ Their comfort with therapeutic categories grew with their admiration of Norman Vincent Peale, who kept his New Thoughtinspired psychology at the fore. Faith evangelists regularly published his articles; by

\footnotetext{
${ }_{77}$ Roy A. Harthern, “A Positive Confession of Faith," Charisma, November 1975, 20-21.

${ }^{78}$ Pauline Harthern, "What You Say Can Hurt You or Help You," Charisma, November / December 1975, 23.

${ }^{79}$ Dennis Roberts, “Trinity Broadcasting Network: The Dream Almost Didn't Happen," Charisma, June 1983, 90.

${ }^{80}$ Avanzini, It's Not Working, 114.

${ }^{81}$ Williams, "Pentecostal Healing", 181-185.
} 
1980, Charisma had featured Peale alongside Gloria Copeland as the two leading authorities on divine prosperity. ${ }^{82}$ Robert Schuller carried Peale's message forward to become one of the most watched televangelists of the 1980s and 1990s. His enduring appeal lay in his theology of self-esteem, a belief that optimism, rather than talk of sin, restored Christians to wholeness and right standing before God. Schuller continued his focus on inspiration and anecdotal, nurturing Sunday messages. His preaching was equal parts liberal Protestantism and business how-to, as he pushed congregants to “spot new opportunities, solve more problems, achieve bigger goals, enhance your leadership skills, manage money better . . a and much, much more." ${ }^{83}$

From the 1990s, prophets of soft prosperity dominated. Paula White, the senior pastor and co-founder of megachurch Without Walls International Church in Tampa, rose among the ranks of televangelists as a specialist in self-esteem, emotional healing, and divine prosperity. Calling herself a life-coach and motivational speaker, as well as a preacher, White became the everyday woman who offered biblical solutions to poverty and a broken spirit. Her books, You're All That; Deal With It!; Simple Suggestions for a Sensational Life; Birthing Your Dreams; and He Loves Me, He Loves Me Not, promised to deliver readers, especially women, from pain that might ultimately prevent victory. The thought-world was potent, and readers would have to learn to get their minds to "work for them." ${ }^{84}$ She traced the relationship between these thoughts, positive or negative, and life's circumstances.

Your thoughts become your words. Your words become your actions. Your actions become your habits. Your habits become your character.

\footnotetext{
${ }^{82}$ Norman Vincent Peale, "The Law of Supply and Abundant Living Will Work For You," Charisma, September 1980, 33-37.

${ }_{84}$ Robert Schuller, Possibility Thinking (Chicago, IL: Nightingale-Conant Corp, 1981), 1.

${ }^{84}$ Paula White, Birthing Your Dreams: God's Plan for Living Victoriously (New York: Thomas Nelson, 2003), 104.
} 
Your character becomes your destiny. ${ }^{85}$

She urged people to take practical steps to improve their credit scores, but also tirelessly promoted First Fruits as a supernatural means of debt relief. Prosperity might find believers by the winding road of job performance or godly self-esteem, or by the super-highway of God's instantaneous miracles.

African American Faith teachers, in particular, often tempered hard prosperity by emphasizing the slow work of upward mobility. Bishop Noel Jones, pastor of the 10,000-member City of Refuge church, demonstrated this commitment in Vow of Prosperity. His soft prosperity defined success as the net result of right thinking because "your spirit will either attract negatively or positively," but he also lent equal weight to the gritty details of financial management. ${ }^{86} \mathrm{He}$ warned readers of the dangers of overnight success, urging them to embrace the process of receiving God's blessings. Some white ministers followed suit. Megachurches like Joel Osteen's Lakewood Church added financial counselors to the roster of their ministry, advising churchgoers to change their minds and their habits. Those in debt must take "a step of faith," urged Osteen. Divine increase and promotion came even to those who needed budgets.

\section{Sunday Prosperity}

Most Sunday services passed without a word from the First Lady of the Victorious Faith Center in Durham, North Carolina, who appeared calmly to accept her husband's fiery prose, nodding or fanning herself. Her stillness may have been mistaken for mildness, but she too had a stubborn fire. Other worshippers seemed to draw their enthusiasm from the crescendoing piano or the pastor's admonitions, rather than the

\footnotetext{
${ }^{85}$ Ibid.

${ }^{86}$ Noel Jones and Scott Chaplan, Vow of Prosperity: Spiritual Solutions for Financial Freedom (Shippensburg, PA: Destiny Image, 2007), 30.
} 
stolid presence of the First Lady. Yet one Sunday, the First Lady of VFC unexpectedly rose from her seat in the first row, turning towards the congregation.

Faith requires action, she declared with surprising volume. Faith requires believers resist signs of the Satan's power-disease, poverty, and lack-and reclaim God's abundance. Her small stature rose with the room's excitement, as she led believers in an exercise to put poverty in check. She urged everyone to stand and prepare to receive. She explained that after she called, "Money cometh unto me, NOW!," each congregant must proclaim this Faith and reach out for God's blessings. They must act as if God's financial blessings poured out, and money fell from the sky to meet every need. "MONEY!" she shouted, the congregation calling out with her. "Cometh unto me . . "she paused in anticipation-“... NOW!" With that, the First Lady began to dance. Her legs bounced in place, high-heeled shoes kicked under a chair, and her short arms pumped as she reached high and plucked invisible dollar bills from the sky. The room danced, as some eighty believers, young and old, threw off their inhibitions and joined her. A murmur rose to a din as people began to call out their needs. Most of them fervently reached out for the money visible through their spiritual eyes. Young mothers jostled their babies as they jumped, while elderly women waved their arms to catch what fell. Tears streamed down as people remembered what they desired or the losses that they hoped to replace. "Money cometh unto me NOW!" voices called again, echoing the First Lady's refrain. When the moment faded, feet slowed and hands clutched their findings. The First Lady sank into her seat and resumed her quiet authority, the silent demonstration of what invisible Faith, when made visible, could accomplish. ${ }^{87}$

Faith congregations, unable to find sufficient precedence in Pentecostal and Holiness church practices, developed modern rites to celebrate divine wealth on Sunday

\footnotetext{
${ }^{87}$ Congregational visit, Victorious Faith Church, Durham, North Carolina, July 29, 2007.
} 
morning. Little uniformity prevailed across the Faith movement's diverse congregations, but viewed whole, several trends emerge. Tithing eclipsed the sermon, worship, and communion as the emotional peak of the service, as pastors pushed their audiences to envision greater financial miracles. Soft prosperity churches commonly kept the mood light as the ushers took the offering, reminding audiences "God loves a cheerful giver" (2 Corinthians 9:7). Hard prosperity congregations adopted stronger measures, dwelling on the negative consequences that befell the uncharitable. In the book of Malachi, teachers found ample evidence that Christians cursed themselves when they "robbed God." 88

Financial themes surfaced throughout the service. Congregations might open the worship service with positive confessions tailored to wealth, such as "I am out of debt. I am healthy and wealthy. I'm having good success." Testimony found new purpose as churches made liturgical space to glorify the financial and physical improvements in their members. Small churches allowed members to pipe up with news of a newly acquired car, promotion, or home, while megachurch pastors read them aloud in a segment for prayer and praise.

The public spectacle of giving grew. Innovative tithing rituals compelled members to present their donations before curious eyes. Numerous black Faith churches followed sanctified church custom in asking all present to stand and file past the offertory plate or (in the case of megachurches) bucket. ${ }^{89}$ Empty-handed believers touched the bucket and prayed that they might soon have something to give. Lynette Hagin, Kenneth E. Hagin's daughter-in-law, introduced a tithing convention adopted by many Word of Faith churches. Participants raised their tithing envelopes in the air and repeated this offering prayer by heart:

\footnotetext{
88 "Will a man rob God? Yet ye have robbed me. But ye say, Wherein have we robbed thee? In tithes and offerings. Ye are cursed with a curse: for ye have robbed me, even this whole nation" (Malachi 3:8-9, KJV). ${ }^{89}$ Given that many of these Faith churches came from the sanctified fold, this was simply a matter of continuity. Filing past the offertory plate had long been the normative practice in working-class African American churches.
} 
This is my seed. I sow it into the Kingdom of God. I sow because I love God and want to see [insert name of church] continue to fulfill what God has called us to do.

I believe that as I sow my seed, it shall be given unto me-good measure, pressed down, shaken together, and running over! It shall come back to me in many ways!

I thank You, Lord, for good opportunities coming my way. I thank You that the windows of Heaven are opening because of my obedience to sow my seed.

I thank You, Lord, for the favor of God upon my life and the grace to prosper, as You have promised me in Your Word. ${ }^{90}$

At the mention of "good measure, pressed down, shaken together, and running over," Rhema Bible Training Center graduates even added playful actions. Other churches laid the bare bills on the platform as the preacher paced the stage littered with cash and checks. The significance of divine wealth led churches to publicize tithing and to set givers themselves apart from the crowd.

\section{Financial Sins}

Leaders proved to be the most powerful demonstrators of divine wealth, as the living testimony and continued revelation of successful prosperity teachers presented an idealized portrait of what it meant to live victoriously. Their chauffeured cars and private jets served as tangible reminders of their blessedness, as Creflo Dollar reminded his congregation: “I own two Rolls-Royces and didn't pay a dime for them. Why? Because while I'm pursuing the Lord those cars are pursuing me." ${ }^{91}$ As embodiments of prosperity, prosperity pastors offered tangible reminders of God's goodness and the abundant provisions in store for all who believed. Frederick Price, pioneer of African American prosperity theology, made his financial success a perennial theme with a theological bottom line: "I'm only doing it so that you can see that there's somebody the same color that you are, breathing the same contaminated air, paying the same

\footnotetext{
${ }^{90}$ Lynette Hagin, “Offering Prayer,"

http: / / www.rhemabiblechurch.com/PDFs / Bulletins / Bulletin112209.pdf (accessed December 20, 2009). This practice served as a continuation of the historic Pentecostal emphasis on palpability, contrary to the common assumption that this was a movement characterized only by spirit.

${ }^{91}$ Kelefa Sanneh, "Pray and Grow Rich," The New Yorker, October 11, 2004, 48-58.
} 
outrageous prices for everything else, and I'm prospering because of the Book." ${ }^{92}$ In short, they served as "proof-producers," divining rods for the community to understand the work of the Lord.

Dollar's rise to fame demonstrated this desired career trajectory. When Atlanta singer and rap-phenomenon, Ludacris, starred in the music video, "Welcome to Atlanta," a faux-tour of his city's hip-hop landmarks, Pastor Dollar was the first stop. Between footage of a raunchy tour guide and Ludacris's camera-close rapping, the Senior Pastor of World Changers Ministries stood solemnly in front of the 30,000member facility that had made him an urban black sensation. As pastor of the fifteenthlargest church in America, an African American congregation, Dollar's popularity reached into unlikely spheres. As the spiritual son of Kenneth Copeland, an older generation of Pentecostals respected Dollar's exuberant traits. Handsome and quickwitted, his female fan base crossed racial lines and ensured his frequent invitations to women's conferences. In 2008, for example, Joyce Meyer's Women's Convention slated Dollar as the sole male speaker. A popular presenter among diverse sectors of the American Christian landscape, Dollar succeeded in bringing an urban black ministry to national acclaim.

Dollar's reputation was born and bred in Atlanta. A native of College Park, Georgia, Dollar grew up in the Methodist church, converting to Pentecostalism as a teenager. His first pastoral efforts came in West Georgia College, where he pursued a Bachelor of Science in Education. He and a roommate started a Bible study entitled "World Changers Bible Study." Under his guidance, the Bible study grew to three hundred attenders. ${ }^{93}$ Dollar's education, though unrelated to theology, later equipped

\footnotetext{
${ }_{92}$ Deborah Potter, "The Prosperity Gospel," Religion E Ethics Newsweekly, http: / / ww w.pbs.org/ wnet/ religionandethics / week1051 / feature.html (accessed December 21, 2009). ${ }_{93}$ Dr. Creflo A. Dollar, "How It All Began," Changing Your World, August 2001, 6-9.
} 
him as a teacher and self-help advisor. He later went on to receive his M.A. and Ph.D. in counseling. In 1986, Dollar left his work as an educational therapist at the Brawner Psychiatric Institute to found a church. He held his first service on February 7, 1986, in the cafeteria of Kathleen Mitchell Elementary School in College Park, Georgia. The eightmember congregation added to their numbers steadily, though not meteorically, despite Dollar's ambitions. ${ }^{94}$ Yet in the early 1990s, the church's growth increased exponentially. In 1991, Dollar began construction on an \$18-million facility, the “World Dome." While large-scale building projects formed the rule, not the exception, in Faith ministries, Dollar's projects facilitated both his growing ministry and a spiritual symbolism. In keeping with his teachings against debt, Dollar refused any bank financing by gradually paying for the facility himself. By December 24, 1995, World Changers Ministry International began services in the new 8,500-seat sanctuary and Dollar proved his theological point. As his church biographers stated, "The construction of the World Dome is a testament to the miracle-working power of God and remains a mode of debtfreedom that ministries all over the world emulate." ${ }^{95}$ Dollar and his World Dome garnered national attention as the fresh face of America's prosperity movement.

Dollar majored in spiritual finances. His television program, Changing Your World, begun in 1990, captured almost 200 television stations and cemented his reputation as God's financier. Each broadcast offered strategies to achieve Christian victory, largely through the "supernatural method of finance." 96 The close of his November 24, 2004, broadcast explained the issue clearly. As Dollar sat comfortably beside his wife, Taffi, they summarized the findings of their series, "Becoming Financially Fit." "God is the one giving us the power to get wealth," he explained,

${ }^{94}$ Billingsley, It's a New Day, 125.

${ }_{95}$ Creflo Dollar Ministries, http: / / www.creflodollarministries.com, (accessed August 15, 2008).

${ }^{96}$ Creflo Dollar. Changing Your World, streamingfaith.com (accessed November 24, 2004). 
quoting Psalm 66:10, that "we went through the fire but thou brought us to a wealthy place." He smiled jubilantly as he arrived at the punch line: “We've been bought out! And brought out!" God saved and rewarded, a lavish promise to every believer. His dozen popular titles like Total Life Prosperity (1999), No More Debt!: God's Debt Cancellation Strategy (2001), and Claim Your Victory Today (2006) detailed his financial promises from God. Dollar's consistent focus on godly acquisition made financial empowerment seminars a hallmark of his ministry,

Fellow Faith teachers hailed Dollar as one of the youngest success stories of the American Prosperity movement. In 1998, Oral Roberts confirmed his achievement with an honorary Doctor of Divinity degree, and a host of like-minded preachers, black and white, counted him as an ally. His was an unlikely accomplishment: a multi-million dollar ministry in an Atlanta neighborhood where 20 percent of citizens lived below the poverty line. Yet the ministry itself seemed proof that Dollar's optimistic brand of selfhelp delivered concrete results.

Believers, for the most part, wanted their leaders to live well. Yet these flesh-andbone examples of lavish living rarely escaped the criticism that they exploited their followers by profiting from their donations. Media pundits relentlessly catalogued televangelists' assets and expenses as evidence of probable greed and corruption. Insiders protested that heaven's windows stood wide-open, so pastors hardly could be faulted for acting on a divine prescription for prosperity. In truth, believers rarely acknowledged the line between manipulation and abundant living until it had been crossed. In 2007, heated criticism met the publication of images of Dollar's mansion, as did reports of Ohio evangelist Joyce Meyer's \$23,000 toilet seat. ${ }^{97}$ Yet, at face value, these mementos of wealth should not have been a theological problem. Their divine

\footnotetext{
${ }^{97}$ Billingsley, It's a New Day, 125.
} 
economy operated on the principle that they lived in a world of more-than-enough. It was typically when pastors mishandled funds that believers lost faith. When Jim Bakker defrauded shareholders of Heritage USA, the problem at first was not that he profited. That he resorted to deception undermined the grounding logic of his gospel: wealth comes to any and all who ask. If accumulation was easy, why do it secretly? And why must he do it at the expense of others? Bakker, by his actions, seemed to live in a world of not-enough.

The mighty fell hard. Famed Faith teacher Robert Tilton made national news when reporters showed him dumping thousands of prayer requests into the dumpster after removing the money from the envelopes. In 2007, a lawsuit alleging the illegal use of university funds forced Richard Roberts to resign his presidency of Oral Roberts University. The same year, Senator Chuck Grassley of Iowa opened an investigation into the finances of many of the most famous names in prosperity theology: Benny Hinn, Eddie Long, Joyce Meyer, Kenneth and Gloria Copeland, Creflo and Taffi Dollar, and Randy and Paula White. It was a narrow road, and few ever managed to walk it without rebuke.

Some gave up the prosperity gospel altogether. Jimmy Swaggart was one of the first. In 1982, Swaggart excoriated his fellow televangelists in The Balanced Faith Life for espousing prosperity theology, retracting the message that he had espoused in The Confession Principle and the Course of Nature, published earlier that year. ${ }^{98}$ Jim Bakker's post-prison biography I Was Wrong decried the Faith message as false. The globetrotting healer Benny Hinn waffled. As the historian Randall Balmer observed, "He at times has issued a public recantation of his 'health-and-wealth-theology,' only to return to it

\footnotetext{
${ }^{98}$ Jimmy Swaggart, The Confession Principle and the Course of Nature (Baton Rouge, LA: Jimmy Swaggart Ministries, 1981); Jimmy Swaggart and Marvin E. Solum, The Balanced Faith Life (Baton Rouge, LA: Jimmy Swaggart Ministries, 1981).
} 
again." ${ }^{99}$ The celebrity T. D. Jakes played both sides of the prosperity debate. Though he closely associated himself with prosperity preachers, promoting the ministries of upand-coming Faith teachers like Paula White, he avoided the "P-word" for fear of "being positioned in a camp of preachers who some say have marginalized the Gospel and relegated it in favor of capitalist ideals." He rejected the "so-called prosperity gospel" as a confused attempt to reach a "capitalistic, tax-sheltered heaven." ${ }^{100}$ The elderly Kenneth Hagin penned The Midas Touch to correct some of the abuses of the movement he helped shape, forbidding ministers from "lead[ing] people to believe that prosperity means conspicuous, lavish wealth. It simply is not true that everyone who has faith for prosperity will live in a palace, drive a luxurious car, and dress in expensive designerlabel clothes." ${ }^{101}$ He chastised preachers who sought their own financial gain, corrupting spiritual truths with wrong motivations at the expense of the Body of Christ. ${ }^{102}$ Yet the message that Faith works proved so successful that no one, not even Hagin, could take it back.

\footnotetext{
${ }^{99}$ Randall H. Balmer, "Benny Hinn," in The Encyclopedia of Evangelicalism (Waco, TX: Baylor University Press, 2004), 336.

100 T. D. Jakes, Reposition Yourself: Living Life Without Limits (New York: Atria Books, 2008), 221.

${ }^{101}$ Hagin, The Midas Touch, 94-95.

102 Kenneth Hagin, on reflection, distinguished moderate from lavish wealth. Before his death, he assembled a meeting of some of the leading prosperity preachers (including Kenneth Copeland) and chastised them for an excessive focus on money.
} 


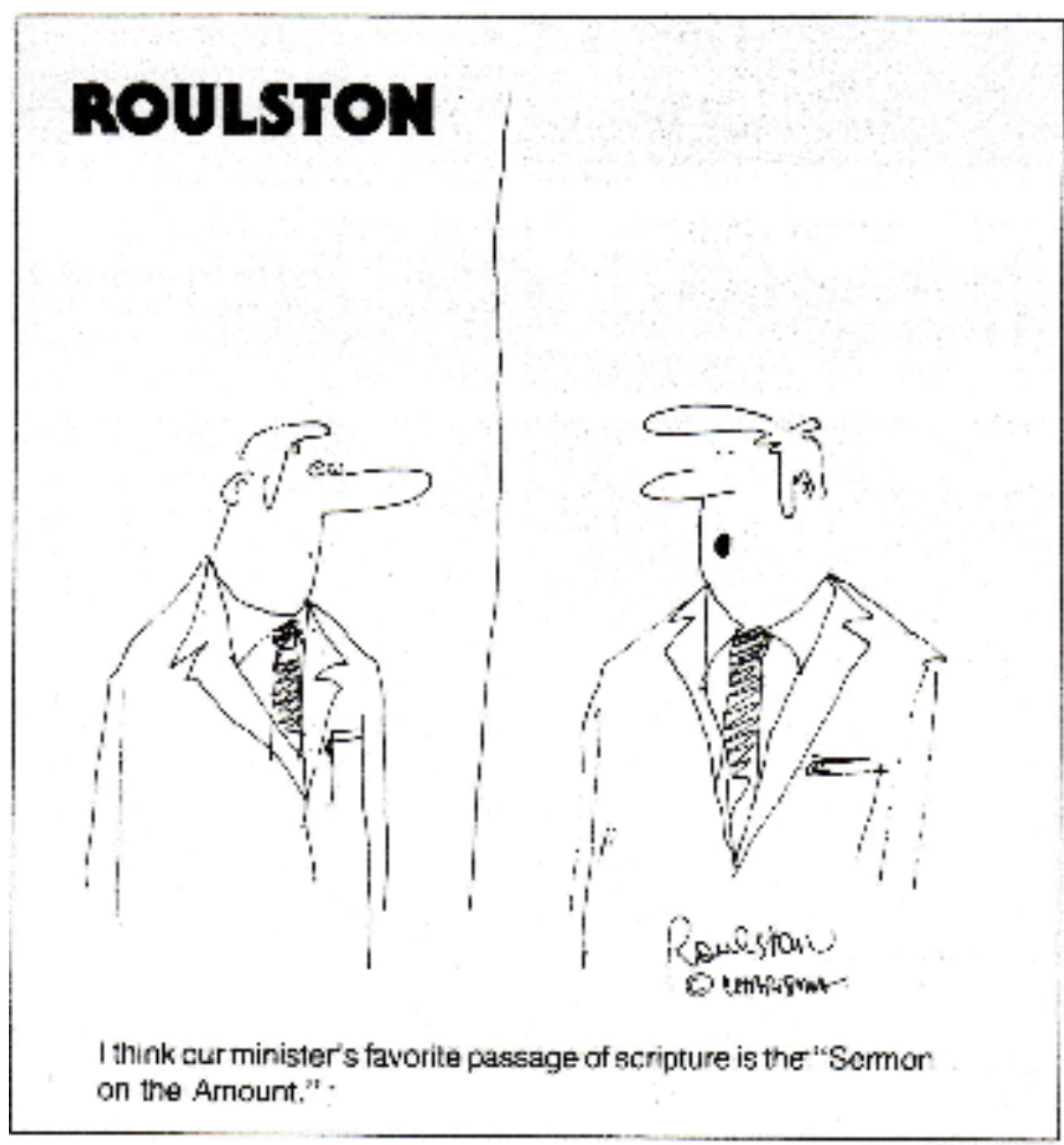

The humor of some attempts to extract tithes was not lost on believers. Roulston, Charisma, June 1979, 28.

\section{Holes in Their Pockets}

On a muggy July evening in Winston-Salem, I joined churchgoers from across

North Carolina to celebrate the $36^{\text {th }}$ ministerial anniversary of the gospel music legend Shirley Caesar with featured guest Paula White. ${ }^{103}$ I anticipated that the Florida evangelist White would provide most of the prosperity-related fodder for the evening, as I had previously visited Caesar's 1,500-member Mount Calvary Word of Faith church in

\footnotetext{
${ }^{103}$ Shirley Caesar Ministerial Anniversary, Lawrence Joel Veterans Memorial Coliseum, Winston-Salem, North Carolina, July 18, 2008.
} 
North Carolina's Research Triangle and noticed only the faintest outlines of a Faith message. White, mired in divorce proceedings from her husband and co-pastor, attracted a smaller crowd to this conference than the organizers predicted, and the sweet chords of the preliminary worship rang hollow off the arena walls. The emcee, a polished staff member of Caesar's church, transitioned from worship to the offertory with a sharp admonition. The cost of this event, she warned, would burden Pastor Shirley if people were not generous in their offerings. In fact, God had given Pastor Shirley a vision of a hundred women marching with a hundred dollars to place on the stage. With them, she believed, seven business people were being called by God to march with seven thousand dollars in hand. As the emcee elaborated on where the women would stand and in what formation, an uncomfortable realization dawned. No one moved. The crowd was as silent as three hundred people in a tin-can arena could be.

The emcee persisted through more silence, urging the women to stand and prepare to march for God. "One hundred dollars! How many will stand with one hundred dollars?" The crowd answered with silence. "Seventy-five?" Rustling. "Fifty?"

“We don't have it!" a woman's voice called from the crowd. A few peals of laughter reverberated through the crowd, followed by more silence. The economic recession and rising gas prices had struck average Americans hard, and the unidentified voice named the uncomfortable truth.

The emcee, a willowy middle-aged woman in a tweed suit, tugged on her pearl necklace, visibly flustered. “Because you said that, you'll NEVER have it! The Bible says that death and life are in the power of the tongue," she shot back. The crowd answered with brief applause. "You've lost the opportunity of a lifetime!" she continued in a lengthy reprimand. Three women stood in their seats, and the announcer jubilantly gave them their marching orders. More followed when she implied that credit cards sufficed. "You charge a vacation! Why not charge a miracle?" Though the emcee declared that she 
would not beg, she continued to squeeze the crowd for donations. She instructed the audience to turn to one another and say: "Neighbor, did you give what you were supposed to give? Tell them, I'm not going to sit by you unless you're here to get blessed." As newcomers gathered at the front, Shirley Caesar moved among them offering words of prayer and encouragement while the announcer closed with a final word: "I want you to write a check for a thousand dollars. I declare that as you walked [to the front] you walked into a new level of prosperity!" Ready or not, it seemed, the harvest beckoned.

Give and get. Divine prosperity rested on a simple exchange. To be sure, careful preachers warned believers against giving to get, but all agreed that openhearted givers should expect to see significant returns. Money served as a common and practical means of assessing one's faith. Yet the actual calculation of gains and losses in a believer's life proved more difficult. Whether donations appeared in the heat of a crusade or the cool of a casual Sunday, believers often struggled to account for precisely how much the prosperity gospel yielded.

Every now and again, divine wealth came as miraculously as a sudden bank transfer or a mysterious envelope of cash in the mailbox. Joan, a visiting prophetess to the Victorious Faith Center, testified that her $\$ 255$ tithe was recompensed by following God's instructions to find the same amount in a parking lot of a particular store. ${ }^{104}$ Yet most often, calculations demanded a roundabout arithmetic. One of Kenneth Hagin's favorite examples of financial obedience illustrates this calculus at work. A poor widow in his congregation scarcely had enough to eat but faithfully paid her tithes. One night during a revival, the woman's mentally ill daughter accepted the gospel and was miraculously restored to near-perfect mental health. She soon married. Hagin later

\footnotetext{
${ }^{104}$ Congregational visit, Victorious Faith Church, Durham, North Carolina, March 29, 2007.
} 
discovered that the young woman's husband died in a truck accident, and that his ample insurance left her several hundred thousand dollars. "I was so glad, praise God," wrote Hagin, "that I had obeyed God and had taken her mother's tithes. This girl had learned to pay tithes, too. ... Would she ever have gotten to that place if she hadn't been obedient in her finances?" 105 To the casual observer, the connection between a mother's donation and her daughter's widowing seemed a long way apart. Yet the faithful saw providence, not coincidence, at work. As Paula White explained, "He is the master puppeteer who is making all the right moves, orchestrating each event that comes your way, preparing your blessing ... and He is doing everything that concerns you in His perfect time." ${ }^{106}$ No circumstance fell outside God's purview. Believers did what they did best: they found God in the particulars of their lives. Members of VFC told me of God's providence in securing a loan, a company car, or winning a bidding war over a new home. God provided for them as faithfully as He did for Moses, parting the seas that they might pass through.

The flip side of this same coin was the veiled threat of misfortune for those who tried to escape God's consequences. Evangelist Joyce Meyer recalled that her attempts to avoid tithing caused all her household appliances to break down, exacting from her the amount that her tithes would have been. Because she did not have her "seed" in the ground, she explained, Satan stole her money. ${ }^{107}$ Pastor Walton warned parishioners that robbing God might bring a curse on their houses. Their appliances and cars would break down. "Money gets away from you," he said, shaking his head. ${ }^{108}$ Followers repented of withholding their tithes, but then worried about the residual debt they owed God. “How can I 'clear my account' with Him?" fretted a reader of Marilyn Hickey's

\footnotetext{
${ }^{105}$ Kenneth E. Hagin, Obedience in Finances (Tulsa: Kenneth Hagin Ministries, 1983), 9-15.

${ }^{106}$ White, Birthing Your Dreams, 68.

107 Joyce Meyers, “Thanksgiving," streamingfaith.com (accessed November 26, 2004).

${ }^{108}$ Congregational visit, Victorious Faith Church, Durham, North Carolina, July 29, 2007.
} 
Charisma column. ${ }^{109}$ The world of prosperity formed a closed spiritual system, encompassing all aspects of everyday life. "Spiritual currency works the same as natural currency," explained Gloria Copeland. "If you have an abundance in your natural bank account, you can enjoy plenty of material things. If you have an abundance of faith in your spiritual account, you can enjoy plenty of everything-wealth, health, good relationships, peace, success." ${ }^{110}$ There was no retreat from the spiritual effects of sowing and reaping. Believers treated Faith as a loose equivalent to Christian karma, an explanation for causality in which all actions bore good or ill consequences. It was both the carrot and the stick, as "whatsoever we sow, whether good or bad, is coming up again!"”111

For those who could not yet see prosperity in their own lives, patience became the highest virtue. "Patience! The power twin of faith!" exclaimed Kenneth Copeland. ${ }^{112}$ Virtually every book written on the subject of prosperity addressed the issue of God's timing. Brother John Avanzini listed “No Patience” as one of the twenty-five major obstructions to blessing. "Everything God does is scheduled. . . Just hold on," urged Paula White. ${ }^{113}$ Juanita Bynum's popular song encouraged believers to rest in the gap between asking and receiving with the single, repeated refrain: "I don't mind waiting for you, Lord." 114

Tammy Faye Bakker later recalled that the impetus behind Heritage USA was that they wanted a place to invite followers to catch the vision of PTL. Most preachers undoubtedly would have built a church. That the Bakkers built a Christian wonderland testified to the joyful and enterprising spirit of the movement itself. They had wanted

\footnotetext{
109 Ask Marilyn, “Profitable Words," Charisma, November 1987, 10.

110 Gloria Copeland, No Deposit, No Return (Fort Worth, TX: Kenneth Copeland Publications, 1995), 4-5.

111 Stan Wangenye, God's Will Still Is Prosperity! (Longwood, FL: Xulon Press, 2009), 123.

112 Kenneth Copeland, Dear Partner (Fort Worth: Kenneth Copeland Publications, 1997), 61.

113 White, Birthing Your Dreams, 70.

114 Juanita Bynum, "I Don't Mind Waiting," Flow Records, 2006.
} 
believers to meet Jehovah Jireh, the God of more-than-enough 


\section{Chapter Four: Health}

JEHDVAH RAPHA (MY HEALER)

The Victorious Faith Center (VFC) in Durham, North Carolina was lit up like a Jack-o-lantern on this and every Wednesday night, its sanctuary activities visible through the windows that formed the church's street-facing wall. Sandwiched between a nail salon and a payday loan office, the storefront church warmed the dim streets with shouts of praise and prayer. A dozen or so women-elders, deacons, and mothers of the church-bantered and laughed as they prepared for the service. The chatter ceased when a woman stumbled through the doors and teetered there, her eyes scanning the room and her face twisting as if suffering from some ailment. A mother of the church sprang from her seat, crossed the room, and pulled the woman, a fellow church member, into a tight hug. " "Praise God!" Shouts of encouragement erupted from all corners. The woman's face brightened and ran with tears as people clustered around her in a spontaneous praise circle.

"I'm going to praise His name!" sang the church mother, beginning the familiar tune of a VFC favorite. "Each day is just the same!" joined another. The stomping of tennis shoes on the beige-carpeted floor anchored the chorus: "Look what the Lord has done / Look what the Lord has done / He healed my body, He touched my mind / $\mathrm{He}$ saved me JUST IN TIME." ${ }^{2}$

The woman, Essence, as I soon learned, had just taken her first unaided steps after a sudden illness had left her paralyzed. VFC members celebrated her healing as a

\footnotetext{
${ }^{1}$ In some African American churches, older women who exercised authority and influence in church matters are granted the honorific title "mother of the church."

${ }^{2}$ Mark David Hanby, "Look What the Lord has Done," Exaltation Music, 1974.
} 
triumph over Satan, who robbed believers of the health, prosperity, and abundant life that God granted to all the faithful.

Prosperity theology heralded divine health as a fundamental demonstration of the power of faith. Grounded in the thought of E. W. Kenyon, and following wellestablished Pentecostal precedents, the Faith movement promised divine health as a provision of the atonement, connecting Jesus' crucifixion with believers' physical healing. Faith teachers, though varying widely in interpretation and focus, agreed on three fundamental ideas. First, the promise of healing rested in the more fundamental promise of salvation, as Christ's death guaranteed release from sin as surely as it guaranteed release from illness. The words of Isaiah sealed the promise: "But he was wounded for our transgressions, he was bruised for our iniquities: the chastisement of our peace was upon him; and with his stripes we are healed." (Isaiah 53:5) ${ }^{3}$ Jesus' work on the cross earned not only redemption from sin but also deliverance from its penalties: namely, poverty, sickness, and demonic interference. Second, healing was God's divine intention for humanity. And third, God set up the laws of faith so that believers could access the power of the cross. The primary task of believers was to live into the power of the resurrected Christ by applying faith to their circumstances, measuring their lives and bodies for evidence of spiritual power.

This chapter examines the drama of healing and health as one of the defining features of the American Faith movement as seen in how believers viewed their bodies (along with their finances) as a testing ground for their faith. ${ }^{4}$ Since almost two thirds of American Pentecostals reported that they had been healed, or that they had seen another person healed, it is clear that divine healing lay at the core of what captured

\footnotetext{
${ }^{3}$ Isaiah 53:5 (KJV) Pentecostal, charismatic, and Faith believers embraced other biblical rationales for healing, but the Isaiah passage remained paramount.

${ }^{4}$ The striking absence of mental health and illness in this literature suggests that Faith teachers did not approach psychological health with the same confidence.
} 
believers' hearts in the American Faith movement. ${ }^{5}$ Most prosperity teachers grew to accept a positive assessment of medicine, leaving behind the anti-medical rhetoric that punctuated the postwar healing revivals. A minority, however, maintained their distance from hospitals and doctors and nurtured divine health only by spiritual disciplines such as prayer, fasting, and deliverance. Whether they accepted, or, like VFC, rejected biomedical solutions, believers ultimately put their confidence in the power of a divine prescription: faith.

\section{Miraculous Health}

"Does anyone need healing today?" Pastor John Walton, senior pastor of the Victorious Faith Center, called out to the eighty assembled before the close of the service. During my time at VFC, I had seen dozens of people respond to his call for healing. A middle-aged man I recognized as new to the congregation approached the altar and the two quietly discussed his symptoms. "Get this man a chair." Walton said. "Sit down!" The congregation sat expectantly as Walton kneeled before the seated man, holding one outstretched leg in his hands. He diagnosed the problem easily. "One leg is shorter than the other!" he exclaimed, and implored God to lengthen the other leg to match. "Oooh!" Walton exclaimed in surprise. “It jumped when I touched it just now!” We waited. Some moved quickly into prayer, both for the pastor and for the patient. Pastor Walton prayed heartily, but not exuberantly, as he asked for God's healing touch. When he finished, a brief expected show of agility followed, as Pastor Walton asked the man to touch his toes several times, like an athlete warming up for a sprint. Everyone burst into applause. Walton smiled. "Praise Jesus!” someone called out.

From the pulpit, VFC preached a clear route to healing. Right standing with the divine focused on sacred alignment, a mystical connection that harmonized the believer

\footnotetext{
${ }^{5}$ See Candy Gunther Brown, Global Pentecostalism (Oxford University Press, forthcoming), Introduction.
} 
with God. Prosperity theology asserted that people shared in God's healing power by activating their faith and tapping into God's spiritual laws. For the sick congregants of the Victorious Faith Center, healing restored both mental and physical wholeness and aligned believers with God's divine intentions. These public acts of healing consistently exhibited a moment of spiritual stasis when believers succeeded in reinvigorating their spiritual authority over the demonic causes of their illnesses. Psychological, social, behavioral, emotional, and physical causes could be rooted out and identified as spiritual realities: a spirit of cancer, a spirit of laziness, a spirit of jealousy, etc. As Pastor Walton argued, “It's all spiritual! It's all spiritual. It is! Because it deals with spirits." What outsiders categorized as distinct etiologies, Faith believers attributed to a single spiritual cause subject to an epistemic cure.

Within this Holy Spirit framework, healing required that belief and practice mutually reinforce one another. Rather than accepting illness with passive resignation, Prosperity believers understood the will as key to mastering the body. As believers understood their senses to be deceptive, ruled by what E. W. Kenyon called "sense knowledge," they did not simply wait for their bodies to assure them that healing had occurred. They believed and acted as if it had. A few examples illustrate the centrality of performances of faith. A respected elder taught Sunday school, where he urged believers to avoid negative confession by keeping their troubles to themselves. "If anyone asks," he said, mimicking a hobbled walk with a crutch, "Just say 'I'm blessed! I'm going on in Christ!" Rather than asking for prayer again and again, the believer must ignore "sense knowledge" and trust that God has already healed because enacted faith would not be limited by circumstances. “On your deathbed you'd better be saying `By His stripes, I 


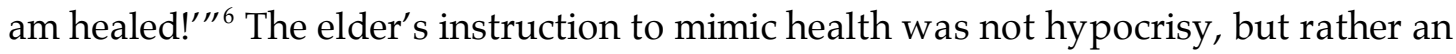
imitation of the desired outcome, entwining action and belief. Going through the motions of divine health, similar to the nineteenth-century Faith Cure practice of "acting faith," put performance on an equal footing with reality. Take the common occurrence of a VFC believer, who, after receiving a revelation from Pastor Walton that they were healed, began a "shout" (an ecstatic dance of praise). Published guides for positive confession of healing and health ended with the prompt, "Now praise Him for it!" as if it were already so. ${ }^{7}$ Or, to return to the case of the VFC member's public healing from a stunted leg, the man was not asked how he felt but rather to perform exercises enacting a healed body. Performance and belief were linked so that believers acted out their healing before they identified symptoms to confirm it.

Leaders performed divine health in its idealized form every Sunday. Many Faith celebrities made their own healing the centerpiece of their ministry, purportedly embodying God's healing power and believers' right to own that power too. Oral Roberts, David Yonggi Cho, and Benny Hinn stood as a few examples. ${ }^{8}$ As a founder of the contemporary Faith movement, Kenneth Hagin and his healing became the standard for all healing narratives. A bedridden teenager suffering from a "deformed" heart, Hagin believed he was no longer sick after reading Mark 11:24: “Therefore I say unto you, What things soever ye desire, when ye pray, believe that ye receive them, and ye shall have them." Hagin's faith allowed him to eschew the Devil's work in causing the illness. As a result, Hagin could state: "I have not had one sick day in 45 years. I did not

\footnotetext{
${ }^{6}$ Faith teachers frequently advocated this unflinching denial in the face of illness. As Kenneth Copeland argued, "The Word says I'm healed. So I say, 'I'm healed! I'll never change. That's it. Nomatter what it looks like, even if I die, I'll go to heaven shouting, 'By His stripes I'm healed."'” Kenneth Copeland, Dear Partner (Fort Worth: Kenneth Copeland Ministries, 1997), 48.

${ }^{7}$ Kenneth Hagin, "Good Confessions," The Word of Faith, December 1977, 10.

${ }^{8}$ Both Oral Roberts and David Yonggi Cho claimed healing from tuberculosis, and Benny Hinn from stuttering.
} 
say that the devil hadn't attacked me. But before the day is out, I am healed." ${ }^{9}$ Prosperity televangelists and megachurch pastors frequently cited their own divine health as the gold standard of faith, encouraging congregants to reflect prosperous living in their own bodies, minds, and circumstances. From prosperity pulpits to television screens to countless books guaranteeing the abundant life, faith teachers emboldened believers to put the laws of faith to physical use.

This application of healing power remained virtually unchanged from its inception in the cradle of the post-war Pentecostal healing revivals. Divine healing stood on certainty. "Your healing," argued Atlanta televangelist Creflo Dollar, "is not based on whether the doctor can heal you; it's based on the Word and your covenant with God for the healing of the your spirit, soul, and body." ${ }^{10}$ After all, God revealed himself as Jehovah Rapha—the Lord who healeth thee. ${ }^{11}$ Even the public tumult over the HIV / AIDS virus in the mid-1980s did little to dampen the Faith teachers' enthusiasm for God's medicine. Healers like Don Stewart and Kenneth Copeland took on seemingly impossible cases with the assurance of the cross. "Receive your healing," Copeland told AIDS victims at his 1987 West Coast Believer's Convention as he embraced them, "for Jesus Christ of Nazareth now makes you whole." ${ }^{12}$ Pastor Walton counted the healing of a man in the final stages of AIDS as one of the most meaningful miracles he had seen. God restored the man when he was delivered of the spirit of homosexuality. Illness, after all, indicated a spiritual problem that required a spiritual solution.

In the 1980s and 1990s, the popular healing ministries of Morris Cerullo, Benny Hinn, Don Stewart, Frances and Charles Hunter, and Kenneth and Gloria Copeland

\footnotetext{
${ }^{9}$ Kenneth Hagin, The Name of Jesus (Tulsa: Kenneth Hagin Ministries, 1979), 133.

${ }^{10}$ Creflo Dollar, How to Obtain Healing . . . the Final Authority (College Park, GA: Creflo Dollar Ministries, 1999), 7.

${ }^{11}$ John Östeen, This Awakening Generation (Houston: John Osteen Ministries, 1964), 15.

12 Steven Lawson, "Copeland Reaches Out to AIDS Victims," Charisma E Christian Life, January 1988, 61. See also Kenneth Copeland, Dear Partner, 55-56.
} 
drew hundreds of thousands of American believers to urban healing conferences. Though promising an alternative (or supplement) to medical intervention, Faith healers appropriated medical language for their own use. In the late 1980s, Larry Lea, former Dean of the Signs and Wonders Seminary at Oral Roberts University, rekindled widespread interest in the power of prayer for healing. He hosted "prayer clinics" with the purpose of unlocking the "secrets of prayer." ${ }^{13}$ Teachers often referred to positive confession as "taking your medication," recommending daily doses of healing-related Scripture to tend to any need. ${ }^{14}$

As before, believers shared faith in the power of religious objects to prevent, diagnose, and treat illness. Many Faith teachers followed the widespread Pentecostal use of handkerchiefs, cloths, or ribbons to facilitate healing. For example, Oral Roberts, Marilyn Hickey, and Benny Hinn made such "points of contact" a staple of their divine healing ministries, asking believers to place an object that had been specially "blessed" on the afflicted area. At times, preachers invested the objects with symbolic as well as magical value. Prosperity pastor Creflo Dollar advised the saints to cure poverty with a dollar bill hidden in one's shoe. ${ }^{15}$ Oral Roberts mailed out thousands of handkerchiefs with an imprint of his anointed right hand so that believers might receive a special blessing by laying their hand upon his. ${ }^{16}$

An anointed ribbon clutched during prayer or a handkerchief mailed by a famous evangelist was not simply a reminder of faith, but a vehicle for it. A letter to Baltimore

\footnotetext{
${ }^{13}$ Stephen Strang, "Larry Lea: Proof that Prayer Works," Charisma, October 1986, 16-20.

${ }^{14}$ For example, Dodie Osteen, John Osteen's wife, taught vast audiences to "take their medicine" in her famous testimony of being healed in the terminal stage of pancreatic cancer. Dodie Osteen, http: / / community.imawitness.com/ Dodie-Osteens-Faith-Healing/video/350741/54126.html (accessed November 12, 2009)

${ }^{15}$ Stephanie Y. Mitchem, Name It and Claim It? Prosperity Preaching in the Black Church (Cleveland: Pilgrim Press, 2007), 76-77. In African American vernacular belief (as linked in the loose system of rootwork), placing a coin in your shoe- often a silver dime- has long been said to bring good luck. This notion can be traced to the beginning of the $20^{\text {th }}$ century, though likely stretched much further back.

${ }^{16}$ Stephen Strang, "Expecting a Miracle," Charisma, March 1981, 30.
} 
evangelist R. G. Hardy illustrates the personalized significance of these objects. “Dear Radio Pastor," wrote M. Adams from Dallas, "I've been reading about your good works and faith you have in Christ. . . . I was having black spots coming over my eyes. I couldn't see good, and it just worried me. I was so worried and weak in my body. I placed your magazine under my head, and the next morning the spots were gone! Thank God for you and your books!" ${ }^{17}$ Smaller ministries like Hardy's typically traded on more experimental forms of the miraculous than the well-established teachers did. Those who relied exclusively on mass mailings typically offered the most unusual tokens, promises, and prophecies. California revivalist Peter Popoff regularly included pages of instructions on how to use his miracle oil, pennies, or handkerchiefs, so that believers might exact the greatest result. Victorious Faith Center churchgoers fondly remembered Pastor Walton's use of an anointed handkerchief as a symbol of a powerful spiritual era. Yet Walton had set aside the handkerchief so as not to seem to rely on it. ${ }^{18}$ A spiritually healthy mind provided the only true immunity. Sickness was a mental contagion and wrong-thinkers spread their diseases. "You know God heals," argued Word of Faith teacher John Avanzini, "You may experience symptoms of a sickness. They may manifest themselves in pain or in some inability. Your mind will want to reason from these symptoms that you are sick and may even become sicker." 19 Healing began with an epistemic change, a mind turned toward God's divine precepts. What the sick required most was knowledge. Quoting Hosea 4:6, Faith healers typically

\footnotetext{
${ }_{17}^{17}$ Letters to R. G. Hardy, Faith in Action, April 1973, 10.

18 That Pastor Walton stopped using the handkerchief points to the ongoing tension between sacred and profane uses of objects. The ritual uses of the handkerchief stood in tension with an emphasis on the sufficiency of positive confession, as prosperity theology taught that the spiritual required no material medium. However, it might also signal that congregants, drawing on voodoo, hoodoo, or black spiritualist ideas of sacred relics, began to see the object as invested with its own power. (In North Carolina, hoodoo played the greatest role). The term "contact" itself reflected an intentional distancing from undesirable spiritual corollaries-icon, relic, sacrament-all of which pointed to Catholicism and perceived superstitions.

${ }_{19}$ John Avanzini, It's Not Working, Brother John: 25 Things That Close the Windows of Heaven (Tulsa: Harrison House, 1992), 144.
} 
warned audiences that God's people "perished for lack of knowledge." ${ }^{20}$ Believers needed to ferret out the lying symptoms from the gospel truth-that the faithful were healed the moment they believed. It pitted the mind against the body, whose painful symptoms seemingly contradicted God's promises. In Frederick Price's healing manual, Is Healing For All?, only two short steps separated believers from divine health: 1) Prayer claiming God's promise of health; 2) Thanksgiving and positive confession to be prayed "until the physical manifestations of the healing takes place." ${ }^{21}$ The book coached patients how to maintain a godly state of mind, including warnings to keep silent about how they felt since it would only privilege sense knowledge. However rampant was prosperity theology's materialism, its priority on mind and spirit ran bonedeep.

\section{Sunday Healing}

Under the arched sanctuary of the First Cathedral of Bloomfield, Connecticut, a rich pageantry of spiritual performances unfolded. One hundred choir members filled the loft above the pulpit, along with sharply dressed musicians on electric guitar, bass, drums and electric organ, swaying and belting out their praises to God. On the platform below, at the right of the pulpit stood a small detachment of white-collared pastors who paced and nodded, while at the left of the pulpit sat the spiritual dignitaries on thronelike chairs. There, Bishop LeRoy Bailey, First Lady Reathie Bailey, and the preacher for the morning, presided over the thousand predominately African American worshippers whose waving, singing and shouting filled the space with rousing praise. Performers and audience alternated in this call-response style service, where worship built forty-five minutes of spiritual momentum, from the welcome and announcements to the climactic

\footnotetext{
20 "My people are destroyed for lack of knowledge: because thou hast rejected knowledge, I will also reject thee, that thou shalt be no priest to me: seeing thou hast forgotten the law of thy God, I will also forget thy children." Hosea 4:6 (KJV)

${ }^{21}$ Frederick Price, Is Healing for All? (Tulsa: Harrison House, 1976), 122.
} 
call for "seed money." In the afterglow of the offertory, the Bishop began the celebration of communion by raising the bread: "This is my body, broken for you, do this in remembrance of me." To this customary rite, he added a brief reminder that prosperity would follow in the wake of Jesus' suffering. At this, many cheered. Raising the cup he said: "This is the blood of Christ, shed for you ... but he was pierced for our transgressions, he was bruised for our iniquities, the punishment that brought us peace was upon him." ${ }^{22}$ Here the congregation joined in with the pastor: "And by his wounds we are healed!" Triumphant shouts rippled through the crowd, joyful that the cross had snuffed out any further need for sickness in God's kingdom. Though divine healing seemed best suited for the high drama of an evangelist's Miracle Crusade, most believers were given the opportunity to reach out for the miraculous in the midst of congregational settings.

In the bustle of Sunday worship services, believers found a multitude of entry points to divine health. Beyond the lessons of hearty sermons, church services provided several significant opportunities for worshippers to silence sense knowledge and (so the saying went) take God at his word. The first step, of course, was getting through the door. At VFC, Pastor Walton preached almost weekly about how poor church attendance led to failed health. Once inside church walls, participants could sink into the familiar rhythms of corporate spiritual performances intended to draw them into mental and physical restoration. Through confession, worship, and communion, the saints enlivened their spirits and acted as those whom God had favored.

Worship served as a powerful catalyst for healing. Like most Protestant worship services, music set the rhythm and tone of the meeting, from congregational singing to the barely-there chords accompanying the closing prayer. Within African American

\footnotetext{
${ }^{22}$ Based on Isaiah 53:5 (NIV)
} 
congregations, it further punctuated the sermons with emotional staccatos. In a spiritual world dominated by right-mindedness, music prepared the heart to receive God's truth. As verbal confession set Faith in motion, song offered opportunities for believers to activate the spiritual laws to effect divine healing. Most Sunday Faith services devoted as much time to song as to preaching, and music served as a lengthy and guided form of positive confession. Keeping in mind the two steps to healing-one request followed by perpetual praise - the meaning and forms of right worship become clearer. In the simple and repetitive musical phrases that comprised most prosperity hymnody, worshippers found that they received the right words to accelerate the work of Faith.

At the close of an evening service at World Harvest Church in Greensboro, North Carolina, visiting preacher Kenneth Hagin Jr., the heir and acting head of Rhema Bible Training Center, demonstrated the tight connection between worship and healing. ${ }^{23}$ As his confident alto tapered to a whisper, he reminded the five hundred assembled that “God's cure is the praise cure, and it doesn't cost a dime. So let's start now! Lift your voices!" ${ }^{24}$ The background trio of vocalists began to sing softly. "What do you want?" he called out. "What do you want!?" He urged the crowd to call out their deepest desires. Only a few voices began at first, but more followed until Hagin had to shout above the din. After a minute or so, Hagin and the praise team sweetened the clamor into song with the familiar tune of "Shout unto God":

The enemy has been defeated And death couldn't hold You down We're gonna lift our voice in victory We're gonna make Your praises loud

Shout unto God with a voice of triumph Shout unto God with a voice of praise Shout unto God with a voice of triumph

\footnotetext{
${ }^{23}$ Congregational visit, World Harvest Church, Greensboro, NC, October 9, 2007.

${ }^{24}$ The term praise cure may have been borrowed from Dr. Lilian Yeomans, His Healing Power (Tulsa: Harrison House, 2003), 45-52.
} 
We lift Your name up

We lift Your name up ${ }^{25}$

As the song closed, Hagin paced the low stage. "What are you going to do when you are alone? Praise! What are you doing to do when you need healing? Shout! Praise is the cure!" Hagin looked out at the crowd with satisfaction, and removed his suit jacket. "I was going to close but . . . is anyone having back pain?" A dozen people pressed into the aisle and streamed to the front where Hagin prayed with them, one by one, as a new song promising divine healing rippled through the auditorium. In Hagin's praise cure, music provided not only a theological script, but acted as a trigger for divine healing. It cultivated the atmosphere in which people could name their desires, then offered them the words required to set the principles of divine healing in motion. Worshippers could benefit from the cyclical language of the oft-repeated choruses, repeating positive confessions that ideally allowed participants to "release" their Faith. Finally, Hagin stepped in to complete what music had begun.

Healing and communion accompanied one another with unnoticed harmony. Though the Lord's Supper did not receive the theological and liturgical attention of tithing rituals, it nonetheless served as the most powerful signifier of Christ's resurrection power. For believers, the power was indelibly personal. In the bread and wine (juice,) believers often personalized Jesus' agony as their own. As one of Kenneth Hagin's standard confessions for health specified, "He took my infirmities, He bore my sickness By His stripes I am healed." ${ }^{26}$ Some VFC members surmised that each lash Jesus received in his Passion corresponded to every known disease, ensuring that God knew precisely what the sick endured. Winnipeg megachurch pastor Leon Fontaine went so far as to explain that when Jesus bore humanity's sin on the cross, he physically

\footnotetext{
${ }^{25}$ Hillsong United, “Shout Unto God," Hillsong Music Australia, 2008.

${ }^{26}$ Kenneth Hagin, "Good Confessions," Word of Faith, 1978, 10.
} 
embodied all diseases including (he names specifically), cancer, tuberculosis, and even elephantiasis. The comfort lay in the specificity, the knowledge that Jesus' pain and victory embraced one's own. In this way, Jesus became a deeply personal Savior, whose body experienced and conquered each ache and pain.

Communion carried powerful healing properties. Some followed evangelical Protestants in treating the Lord's Supper as a symbol and token of remembrance. "We take communion to remember what Christ already accomplished for us," remarked Mark Brazee, pastor of World Outreach Church in Tulsa. If what people lacked was knowledge, a reminder would suffice to effect divine health: "Communion services should be some of the biggest healing rallies around because we should partake of the emblems, saying, 'Thank You, Jesus, by Your shed blood my sins are washed away. By Your broken body, I'm healed." ${ }^{27}$ For others, when traditional means of healing failed, people held out hope that bread and wine might hold an extra measure of resurrection power. Benny Hinn offered the elements as a means of transmitting God's healing power, arguing that the bread and wine were much more than symbols. "They are spirit!" he argued fervently, "The body is spirit. The blood is spirit. We take it into our bodies as spirit." ${ }^{28}$ Communion was the ritual by which believers ingested God's spirit in order to restore their own to health. ${ }^{29}$ In his adaptation of the Words of Institution (the narrative of the Last Supper), Hinn asked the crowd to repeat: "As I partake of this bread, heal my body. As I partake of this wine, heal my body. Make my body whole." Communion brought healing power out of the spiritual realm and allowed participants to make it indelibly their own. Miraculous testimonies abounded. Faith evangelist Marilyn Hickey avowed that a wheelchair-bound woman, though "no one laid hands upon her, and no

\footnotetext{
${ }^{27}$ Mark Brazee, 365 Days of Healing (Tulsa: Harrison House, 2006), 244.

${ }_{28}^{28}$ Benny Hinn, Travel to Israel, September 15, 2008.

29 This practice paralleled the Catholic notion of the sacraments as a material vehicle of grace.
} 
one prayed for her" got out of her wheelchair and walked after having received communion. ${ }^{30}$ In word, song, and communion, Sunday gatherings offered worshippers a familiar and supportive atmosphere in which to align their minds to God's truths and experience the fruits of divine healing.

\section{Keeping Your Healing}

Good health required full participation in the liturgical and sacramental life of the church. Devout believers used the week as spiritual preparation for their corporate worship, often fasting, praying, and preparing themselves for what God might have in store. A heightened sense of spiritual intensity electrified Sunday mornings, particularly for those waiting to hear answers to their prayers. Suspended confirmation-a healing believed but not yet experienced-required believers to position themselves to be blessed. Though followers frequently described God's provision as a direct channel, some language suggested a circuitous route between the waiting believer and their personal miracle. When bodies resisted healing, the saints left room for answers to prayer that did not always arrive on schedule. "Some lessons can't be taught," so the saying went, "they can only be caught." Often, believers held out for a word of revelation from the pastor or a visiting evangelist. Prophetic revelations frequently manifested visual cues; one visiting pastor, for example, described seeing clouds above the heads of those for whom he had a message. Angels, doves, dragons, or clouds of light leapt out of the realm of metaphor and danced around the sanctuary, showing God's anointed the spiritual terrain. Pastor Walton's acute spiritual sensitivities allowed him to see and hear things "in the spirit," an ability that allowed him to monitor his congregants' faith lives.

\footnotetext{
${ }^{30}$ Ask Marilyn, Charisma, May 1987, 13.
} 
Those with chronic pain or problems did not revisit the altar. As healing had unfolded once-and-for-all, church life did not make liturgical space for those whose prayers had not yet manifested. Ruth, a pillar of VFC, lived in the not-yet. She did not yet experience the benefits of her faith, and she struggled with an ailment she would not speak aloud. Although Ruth had become one of my closest consultants and someone I considered a friend, she avoided being interviewed. Concerned, I asked Ruth's best friend and another close consultant, Anita.

"Is she worried about having to talk about the fact that she .. ." I stumbled for words, "hasn't been healed?"

“No. No," Anita countered quickly. "She has been healed. She is just claiming her healing. No, I think she's worried about negatively confessing." Saints who had "claimed their healing" must maintain their faith until the physical evidence corresponded to the mind's assent, a process known as "keeping their healing." Spiritual vigilance characterized this period, as believers had be careful not to speak or act in any way that might hinder their blessing.

God's healing promise was that all who ask will receive healing, but few who received God's blessings "keep" them. As Israeli-Canadian healer Benny Hinn explained, "we know that in the presence of God there is healing, and I would give all that I have to see people healed, so I really believe it is the fault of the person. They have failed to enter into God's presence and allow Him to touch them." ${ }^{31}$ On returning from a Creflo Dollar conference in Atlanta, a VFC elder described his disappointment that, though every attendee had received healing, few maintained their divine health. Careless words were the common culprit. Pastor Walton recalled a healing service where he saw a woman cured of arthritis, though only a short while later that same woman was clearly

\footnotetext{
${ }^{31}$ Sherry Andrews, “Anointed to Heal," Charisma, April 1979, 14-17.
} 
not healed. "I know you delivered this lady," he told the Lord hesitantly, to which God replied: "Listen to what she's saying." When Pastor Walton approached the woman about her healing, she told him that she had arthritis. "She was claiming it!" Walton said incredulously, "And when I tried to talk to her about changing her confession, it was a losing battle. You could confess your faults, or you can confess your faith. Many times Christians say the wrong thing," he concluded. To be sure, not all avid participants required this discipline of themselves. For example, Alisha, who had grown up in the church, wandered into church one Sunday long after the sermon had begun and plunked down loudly in the back row beside me. She had been sitting out in the car for most of the service, as she explained to me in a congested voice. After she blew her nose loudly a few times, she abruptly stood up again. “I'm sick! I'm going home!” she half-whispered, loud enough for most to hear. Nonetheless, come Sunday morning, most VFC members attempted to live by these guidelines, limiting their small talk to positive subjects and spiritual topics.

Divine health, at times, was a difficult pill to swallow. Prosperity theology promised once-and-for-all-healing, a mechanism that immediately released God's power in people's lives. The saints asked and received healing in a single moment. Yet in the long stretches between the spiritual peaks of the Christian life, believers had to make sense of the waiting without the comforts of soliciting prayer. "If you pray and you believe that you have received you can never pray about it again," argued Frederick Price. "Only to the extent of thanking the Lord that you believe you have it . . but you sure can't ask for it again. Because if you ask for it again, you've just said by asking that you didn't believe you received it. And therefore the system is short-circuited. And it 
can't work! Because if you did have it, why would you ask for it again?" ${ }^{32}$ For some, this silence led to new isolation. One interviewee described his father's place of prominence within a Faith church until he got cancer. Weekly, his father would go up to the altar for prayer. Finally, the church leaders instructed him to stop coming for prayer, saying "there's nothing else anyone can do for you. You have to heal yourself." In the certainty of prayer and healing, patients struggled to keep their healing using right confession and thanksgiving, waiting for one spiritual season to change into the next.

\section{Deliverance}

Pastor Walton, senior pastor of the Victorious Faith Center, relished the memory of his realization that "traditional" Christianity was dead. Reared in a black Baptist church in Durham, North Carolina, he had known nothing of miracles and spiritual gifts-just lively preaching and the boisterous praise of the assembled. One Sunday, a man interrupted the Baptist service, approaching the altar with the shrill repetition of "Praise Jesus! Praise Jesus!" Walton, though a layperson at the time, approached the pastor with a warning from God. "God said, 'That's not my spirit in him,," Walton told the pastor. The Baptist pastor, Walton remembered, turned to him sharply. ${ }^{33}$

"You do something!" he retorted.

"I ran up to the man, put my hands on him, and I declared 'In the name of the Lord Jesus, come OUT of this man!'” The man dropped to the ground, shrieking, and moved across the floor. Walton's eyes widened in the telling. "He moved across the floor like a snake. Like he had not a bone in his body." Walton grabbed the slithering demoniac by the leg as the man vomited up the spirit as a green glistening sac on the

\footnotetext{
${ }^{32}$ Frederick Price, Azusa Street Centennial General Sessions (CD), (Divide, CO: Kingdom Recordings, 2006). Price likely received this teaching from Kenneth E. Hagin, who wrote, "I am convinced that if most Christians would quit praying and start praising God, the answer would materialize right aw ay." Kenneth E. Hagin, What To Do When Faith Seems Weak \& Victory Lost (Tulsa: Kenneth Hagin Ministries, 1979), 113. For a theological comparison with late $19^{\text {th }}$-century evangelicalism, see King, Only Believe, 268-276.

33 Pastor John Walton, interview by author, Durham, NC, February 3, 2007.
} 
church floor. In the chaos of the altar scene, Walton glanced back at his pastor. There he was, Walton continued, hiding behind the pulpit. Traditional Christianity, for all its Bible reading, praising, and community support, had failed. It was dead without the one thing Walton claimed that day, a word he repeated in his deep baritone: power.

Believers expected to counteract even the most intractable foe. Demonic forces, manifested in any state of mental or physical distress such as anxiety, cancer, or paralysis, were no match for the spiritual weapons Prosperity believers had at hand. "Deliverance," the process of expelling demons, was chief among them. Although the church drew techniques for deliverance from a variety of sources, VFC members largely practiced methods popularized by charismatics within Word of Faith circles in the early 1990s. Using a popular deliverance manual as a guide, the church began a ministry that earned them a local reputation as deliverance specialists. ${ }^{34}$ The Deliverance team, men and women trained for spiritual warfare, would first privately question the participant about their sins, asking a comprehensive list of questions designed to inventory the person's spiritual history. In what often took hours, the participant pored through the past and present to shine a light on all demonic manifestations embedded in habits, generational curses, and emotional distress. The team, through prayer and the laying on of hands, commanded the devils in Jesus' name to be gone. In a spiritual practice referred to as "purging," the believer was coached to cough up the demons by vomiting. ${ }^{35}$ This preliminary deliverance required total disclosure by the patient and sincere repentance, as an incomplete deliverance yielded the return of multiplied demonic forces. Once delivered, believers were encouraged to "take themselves through

\footnotetext{
${ }^{34}$ The church used this Baptist handbook as a deliverance manual: Frank and Ida Mae Hammond, Pigs in the Parlor: The Practical Guide to Deliverance (Kirkwood, MO: Impact Books, 1973).

${ }_{35}$ For more on this view of purging, see Don Basham, Deliver Us from Evil (Washington Depot, CT: Chosen Books, 1972), 206-207; Derek Prince, They Shall Expel Demons: What You Need to Know about Demons - Your Invisible Enemies (Washington Depot, CT: Chosen Books, 1998), 212-214.
} 
deliverance," purging the spirits in their bathrooms at home and praying the blood of Christ upon themselves.

As a researcher accompanying nine hundred participants on Benny Hinn's official tour of the Holy Land, my own encounter with deliverance came as a surprise. On route to our second encounter with Benny Hinn (a sermon delivered on the shores of the Sea of Galilee) an unscholarly thing occurred. I got sick. Our concerned guide quickly identified it as heat exhaustion, common among tourists. My symptoms drew general dismay. As I soon realized, being even mildly ill among people who searched their bodies for evidence of spiritual power proved especially dramatic.

I was too sick to hear most of the crusade. My seatmate on the bus, Sarah, had tried escorting me to the event but I had had to turn back.

"Actually, I think I might have to meet you later. Could you save me a seat?" I asked.

"Sure," she said and stopped, looking at me more intently. "I can see that it's not out of you yet."

It. What was inside of me suddenly took not only shape, but also character. I found refuge in a nearby hotel and soon fell asleep on a lobby couch. I awoke to Sarah's concerned face as she kneeled beside me.

“Kate, I came back because I needed to tell you something. I didn't want you to be afraid. What's inside of you is trying to come out," she continued. "What are your symptoms?" I hedged. A polite Canadian never talks about such things.

"My stomach. My head hurts." She frowned.

“Your head hurts because you've been forcing it down by thinking too much. You're 162 
too much up here," she said, gesturing to her head. "Okay? You can't reason your way out of this. This is spiritual. What's inside of you is a spirit trying to get out." She pressed on. "Have you thrown up just now?"

"No," I said. She frowned again.

"You need to vomit this out." She paused. Perhaps she sensed my distress or fatigue, because her forehead crinkled and she smiled reassuringly. "Don't worry! There is no sense trying to figure out why this happened. It could be any number of things. You said that you talk a lot so maybe it was something you said. Or something you did. But it doesn't matter. Now is not the time and the Holy Spirit will reveal it to you when you're ready. And don't be embarrassed! This happens to everyone. I just want you to know what to do about it. I want you to go into the bathroom and try to throw up. And if you can't, just go like this," she said, mimicking gagging. "You'll be doing it by faith." With that, she stood up abruptly. She flashed a brilliant smile. "You'll be fine." And she left.

Sarah had just advised me to exorcise myself of a spiritual demon. Indeed, purging as a spiritual discipline became widespread in the prosperity circles in the 1980s and 1990s, taking after Don Basham and Derek Prince's teachings that Christians could be targets for demonic activity and that "in most cases the spirits seem to leave through the mouth." ${ }^{36}$ Purging also illumined the significance of reading signs and acting on them for healing. In a spiritual cosmos oriented by materiality, believers found the body to be an unruly but reliable marker of Faith. Illness became evidence, causally indeterminate,

\footnotetext{
${ }^{36}$ Don Basham, Deliver Us from Evil (Washington Depot, CT: Chosen Books, 1972), 206-207; Prince, They Shall Expel Demons, 212-214. For an excellent example of the argument from within the Pentecostal tradition against Christians requiring exorcism, see David du Plessis, Simple and Profound (New Orleans: Paraclete Press, 1986), 61-63.
} 
but evidence nonetheless. Purging the spirit provided the counter-evidence, proof that demonic forces had fled.

Rather than accepting illness with passive resignation, prosperity believers understood the will as master of the body. Healing required belief and practice in reciprocal relation. Thought without speech, or healing without deliverance rendered their Faith impotent, or rather, proved its absence since believers understood their senses to be deceptive. Sarah's instruction to go through the motions of deliverance-or, earlier, the VFC elder's teaching on mimicking health-placed performance and belief on equal footing.

Observers who focused on the public displays of healing-the high drama of a miracle crusade-might forget that behind these demonstrations, an individualistic ethos was at work. To return to my case, though I got sick at a Benny Hinn Miracle Crusade, no one encouraged me to seek out Pastor Hinn. Rather, believers offered an American prescription: do it yourself.

\section{Spiritual Competitors: Hoodoo}

Across the Faith movement, believers envisioned a spiritual cosmos dominated by unseen forces, divine or demonic, which steered the course of people's lives. Through Christ, believers commanded the authority to declare, as VFC members did in their Sunday confession, “Jesus lives in me. In Jesus' Name, I will cast out all devils. In Jesus' Name, I will lay hands on the sick and they shall recover." Though all the saints equipped themselves to "come up against" demonic interference, not all communities battled the same foe. For the parishioners of VFC, hoodoo and other African American folk practices contended for the saints' allegiances. Although largely invisible to outsiders, hoodoo (known also as "conjure" or "rootwork") survived as a viable religious tradition in African American communities in the Anglo-Protestant South. 
Church members at the Victorious Faith Center spoke openly about its unwelcome presence, either as a supplement to Christianity or as an alternative religious practice.

Hoodoo persisted as a religion of utility. It came to the Anglo-Protestant South through African slaves, who, despite large-scale conversion to Christianity during the Great Awakening, retained elements of their indigenous religious traditions. ${ }^{37}$ The African-based traditions that endured the Christianization of slaves bore few of the markers of an "organized religion" found in its Catholic Voodoo or Afro-Caribbean Santeria counterparts. It boasted no priests or priestesses, sacrificial offerings, gathered community, or even devotion to ancestral spirits and deities. ${ }^{38}$ Instead, hoodoo functioned as a healing practice, rather than a cosmology. By definition, hoodoo referred to "a system of magic by which individual 'workers' serve their clients." ${ }^{39}$ Most often, believers who hired a hoodoo "doctor" or "worker" sought to protect themselves from harm, particularly the evil intentions of others. Charms, comprised of symbolic ingredients (such as hair, roots, or bones) acted as potent spiritual agents. Clients sought charms capable of working for them, as in the case of a woman who purchased a love charm to induce a bachelor to marry. Clients also turned to hoodoo doctors to diagnose spiritual maladies. Hoodoo workers discerned which illnesses were "unnatural," caused by the "hex" or "trick" of a human enemy. For example, a hoodoo worker might identify a charm buried near the house as the origin of a patient's disease. Although some

\footnotetext{
${ }^{37}$ Following Melville Herskovits's The Myth of the Negro Path (New York: Harper \& Bros., 1941) and Albert Raboteau's Slave Religion (New York: Oxford University Press, 1978), most scholars agree that African religions as systems collapsed, but that fragments ("survivals") of an African spiritual heritage remained. For an excellent historiographical summary see Paul Harvey, "Black Protestantism: A Historiographical Appraisal," in American Denominational History: Perspectives on the Past, Prospects for the Future, ed. Keith Harper (Tuscaloosa, University of Alabama Press, 2008), 120-146. I am persuaded by Yvonne P. Chireau's argument in Black Magic: Religion and the African American Conjuring Tradition (Berkeley: University of California Press, 2003), 151, that the African American conjure tradition "coexist[ed] with Christianity as an alternative strategy for interacting with the spiritual realm."

${ }_{38}$ Carolyn Long, Spiritual Merchants: Religion, Magic, and Commerce (Knoxville: University of Tennessee Press, 2001), 74.

${ }^{39}$ Long, Spiritual Merchants, xvi.
} 
concluded that the specialists' abilities came from Satan, and others claimed it was from God, most churchgoers agreed that hoodoo held the power to heal or harm. ${ }^{40}$

For the sanctified believers of the Victorious Faith Center, hoodoo equaled only one thing: witchcraft. ${ }^{41}$ Although people joked about desperate women who put "roots" in a man's food, an equivalent to love potions, the matter evoked deadly seriousness. The African American Faith movement's emphasis on the instrumentality of faith evoked a strong parallelism between the faith's and hoodoo's power to effect change, prompting believers to draw thick theological lines between them. In the Prosperity gospel, negative circumstances visited those who failed to live by faith. Believers expertly sought out the causes of any personal misfortune. They ran from small matters like the common cold to large matters like cancer or a car accident. They often settled upon two answers. First, in most cases, they assumed that their own actions had failed them. The cause and effect ran parallel, as small mistakes warranted small difficulties. For example, a negative word spoken at home may have led to a headache. Second, believers frequently concluded that Satan launched a direct attack on their lives. A car accident on the way home from church, for example, may have suggested that the Devil hated faithful worship. In interpreting misfortune as either an answer to sin or righteousness, believers exhibited the flexibility of interpretation, as the seeming rigidity and certainty of prosperity theology was molded to meet the spiritual needs of individual believers. Many of the larger and more enduring problems believers faced emerged as evil forces. In this light, hoodoo workers' use of hidden charms, secret

\footnotetext{
${ }^{40}$ Long, Spiritual Merchants, 75.

41 "Witchcraft" was an inclusive category. Beside hoodoo and voodoo, it included a variety of "alternative" therapies such as yoga, acupuncture, and meditation. Pastor Walton preached vigorously against such practices, though it did not surface in any interviews with congregants as a concern. In addressing hoodoo and voodoo, however, it may be difficult for scholars to access the "lived religion" of participants. These folk practices, even if not castigated as demonic, embarrass much of the African American community. (See Long, Spiritual Merchants, introduction.) At VFC, if participants dabbled in these practices, they did not say so. Regardless of whether VFC congregants ever encountered hoodoo directly, I draw on their familiarity with it as a spiritual alternative.
} 
attacks and defenses, exemplified Satan's clandestine attacks. God's faithful must be alert to the spiritual forces working against them. Believers exchanged stories of men who fell under the spell of witches and married them, unaware of Satan's shadow over their lives. Pastor Walton warned his congregants about "roots" secretly placed in their food or drink.

Although Satan's attacks might come from anywhere, hoodoo influences did not. Churchgoers pointed the finger at South Carolina. As several members reported, North Carolinians drove down to South Carolina to do "rootwork" or buy charms. Yet as the Hoodoo historian Carolyn Marrow Long, author of Spiritual Merchants, described, hoodoo flourished as a centuries-old healing tradition up and down the southeastern coast, from northern Florida to southern North Carolina. ${ }^{42}$

Hoodoo formed the wicked counterpart to the Victorious Faith Center's triumphant faith. On a community level, it served as an ugly reminder of pain. Pastor Walton, during a Sunday school lesson to committed members, recounted their collective African religious past, "the religion of our ancestors" as one of witchcraft and Satanic worship. Believing that circumstances must bend to the will of every believer, Pastor Walton interpreted African American history as one not only of hardship but also of failure. Slavery, poverty, and suffering must be, in part, God's response to their African witchcraft. Walton's conclusion that black Americans merited the horrors of slavery tempered his belief that all suffering was temporary. God would have rescued all who called out for him.

In short, hoodoo promised people revelation, a clear view of the hidden magic working for or against them. God's anointed preachers, who claimed their own revelatory sight, formed the perfect protagonist to the feared conjurer. Those who relied

\footnotetext{
${ }^{42}$ In these Low Country black communities, African religion survived, in part, because of the greater autonomy afforded to slaves. See Long, Spiritual Merchants, 71-96.
} 
on hoodoo and those who did not reached similar conclusions: evil attacks lingered everywhere. Secret sources of spiritual evil must be excised to restore emotional as well as physical wellbeing.

\section{Spiritual Competitors: Medicine}

In 1984, Hobart Freeman, a once-renowned leader in Faith circles, died of heart failure brought on by festering ulcers. The coroner concluded that the Freeman's ill-fitting orthopedic shoe had caused the ulcerated leg, and Freeman's opposition to medical intervention had prevented him from seeking the help he needed. The celebrated teacher who throughout the 1970s had appeared alongside John Osteen and T. L. Osborn, by the early 1980s had rotted away before the eyes of his followers at Faith Assembly in Wilmot, Indiana-a macabre test of his own faith. Under Freeman's watch, as many as a dozen members of the Faith Assembly died of medically treatable illnesses. ${ }^{43}$ The Faith movement, as a religion of proofs, always found some partisans willing to be tested to the extreme. Though few would follow Freeman to such lengths, in many prosperity congregations medical science proved to be a common, though no less insidious, threat to faith.

Believers protested that doctors, hospitals, and pharmaceutical companies promised materialistic solutions to what the Faith movement deemed to be spiritual problems. Unlike Christian Scientists, Faith believers did not deny the physical reality of illness. Prosperity theology drew on its metaphysical (particularly New Thought) heritage, and denied that the causes of illness originated outside the spiritual mind. Victoria, a head nurse at a major medical facility, explained the distinction during a discussion about how to live by faith while simultaneously practicing as a medical

\footnotetext{
43 Steven Lawson, "Faith Preacher Hobart Freeman Dies," Charisma, February 1985, 110. Sherry Andrews, "The Controversy over Faith," Charisma, January 1982, 44.
} 
professional. I wondered aloud how she and others could diagnose illness without negatively confessing, because labeling the disease as such would speak it into existence or confirm its reality to the believer. Instead of saying "This is what it is," she explained, a believing doctor could say, "This is what we found." Illness as material reality was not an illusion, or the mind's projection. It was, as Victorious Faith believers posited, a physical manifestation of a spiritual problem. To the Victorious Faith Center, illness took on a new ontological status. It did not contest biomedical accounts of its symptoms, but disagreed on the nature of its causes and cure.

Members of VFC accepted medical intervention at different levels. At the level of diagnosis, most accepted biomedical science's authority to name the disease. Although they were warned by the pastor not to repeat it and to whisper it only in prayer, no one questioned the effects of medical intervention. Most believers accepted medical treatment as a supplement to divine health, known as practicing "according to your faith." This provision allowed the saints to accept treatment for more complicated illness while leaving smaller problems to the power of faith. From the pulpit, Victorious Faith Christian churchgoers were encouraged to start with a small ailment-a headache-and find faith commensurate to overcome. Walton himself had overcome his reliance on glasses that way, as he fought through the initial blindness and headaches before gradually regaining sight. Members frequently reminded each other to "start with a headache," using positive confession and the efficacy of faith to overcome small tests before moving on to larger ones. The testimony of one VFC member provides a helpful illustration. Advised that her gallbladder was about to burst, the believer underwent an 
ultrasound, but leapt off the examination table when the preliminary screening seemed positive. Medicine, for many saints, proved diagnostic but not curative. ${ }^{44}$

Complex factors drove some to divine healing. The attraction to spiritual healing may have been a pragmatic one for the underprivileged, as it served as the only available treatment. Benny Hinn's Miracle Crusades, for example, drew heavily from minority and immigrant communities who crowded the stage for Hinn's healing touch. As the theologian Tammy Williams observed, "In a country in which forty-two million persons lack health insurance, twenty percent of whom are African American, Jesus may be the only doctor that some African Americans encounter on a regular basis." ${ }^{45}$ Though most Faith teachers accepted medical help at some level, a distinct minority of prosperity teachers railed against medical science as the panacea for sick bodies. Unlike many underinsured African-American communities, however, the Victorious Faith Center is located in Durham, North Carolina (known as "The City of Medicine") and exhibited a high level of familiarity, knowledge, and access to the healthcare system. Many of the members worked for the nearby Duke University Hospital System as healthcare providers—nurses, laboratory technicians, phlebotomists, pharmacy assistants, etc.and knew the medical solutions available to them during a time of illness. Their critique of the healthcare system stemmed from broader cultural sources, particularly the legacy of past and present failures of the healthcare system to provide African Americans with impartial treatment. Racism dressed as impartial science in the form of intelligence theories, social Darwinism and eugenics, alleged the biological, social, and intellectual

\footnotetext{
${ }^{44}$ At times, spiritual causation trumped medical diagnosis. For example, Pastor Walton argued that a condom could not prevent the spread of AIDS because it could not block the demonic forces that caused AIDS.

${ }^{45}$ Tammy R. Williams, "Is There a Doctor in the House? Reflections on the Practice of Healing in African American Churches," Practicing Theology: Beliefs and Practices in Christian Life, eds. Miroslav Volf and Dorothy C. Bass (Grand Rapids: Eerdmans, 2002), 97.
} 
inferiority of the black population. ${ }^{46}$ The majority of African Americans, unlike their white counterparts, distrusted biological and social explanations for the causes of mental illness. The former implied black genetic inferiority, while the latter characterized the black family as dysfunctional. ${ }^{47}$ In this way, African American Faith churches reflected a popular mistrust for biomedical treatment and categorization of disease, denying the authority of the healthcare system to restore black bodies to health.

Preventive medicine such as flu shots or regular doctor visits created a significant dilemma for many adherents. Even the notion of "Flu Season" articulated a negative confession that, to those towing a hard line, required reimagining as "Health Season." 48 Most VFC believers accepted some healthcare intervention as an unwanted necessity. Vaccinations, for example, were prerequisites for children to attend school or travel abroad. Kenneth Hagin used caution in this matter and was not definitive regarding vaccinations as a definitive test of faith. "It's pretty well up to the individual," he concluded. ${ }^{49}$ Others avoided preventive care as a marker of spiritual honor. “My children have not been to the doctor in years!" boasted a VFC elder. As the processes of globalization heightened the threat of disease, these Faith believers did not blink. Armed with excellent healthcare if they wanted it, believers argued that they already had true "preventive medicine" in a spiritual "bottle," through fasting, tithing, prayer, and worship.

Medical healing posed the most direct threat to the logic of faith. Medicine relied upon the diagnosis of symptoms, signs that believers called "lying symptoms" because they relied upon "sense knowledge" rather than "revelation." Headaches proved to be a

\footnotetext{
${ }^{46}$ W. Michael Byrd and Linda A. Clayton, An American Health Dilemma, 2 vols. (New York: Routledge, 2000-2002).

${ }^{47}$ Brittany S. Carlton, "Mental Illness in the African American Community," seminar paper, University of Indiana, 2009.

${ }^{48}$ See Milmon Harrison, Righteous Riches: The Word of Faith Movement in Contemporary African American Culture (New York: Oxford University Press, 2005), 54-55.

${ }^{49}$ Kenneth E. Hagin, “Is Your Profit Showing?" Word of Faith, January 1976, 4-5.
} 
useful and frequently cited example. Just as Tylenol could not cure a headache but simply numbed the pain, believers indicted medicine as incapable of attacking the root of the problem. Medical reliance on materialistic solutions contributed to believers' untimely demise, the saints argued, as people yielded to their sense knowledge, and would not develop the faith required to subdue their disease. As Pastor Walton preached, most believers with advanced illnesses did not recover because their symptoms had grown stronger than their faith. Medical science bolstered confidence in the material over the spiritual realm, thus doing harm to true faith.

New etiquette arose to handle public displays of illness. For example, rather than answer a sneeze with "Bless you," churchgoers might reply, "I curse that sneeze in Jesus' name!", countering demonic interference with a positive confession. On a congregational visit to a local megachurch, participants instructed me to say, "I'm catching a blessing," in reply to any questions concerning my obvious cold symptoms. The ethnographer Milmon Harrison found that his acknowledgement of his thinning hair received a stern redirection: “Oh, no, don't confess that. We're believing for you a full head of hair. You're not going to lose your hair, in Jesus' name!" ${ }^{50}$ Believers disagreed about the degree to which they should ignore symptoms. Kenneth Hagin Jr., for example, later attempted to temper this preoccupation with the denying of illness, arguing that those who refused to admit they were sick were not being faithful—they were liars. Regardless, believers continued to view disease as having spiritual elements as they examined their own bodies for proof of God's blessings.

\section{Harmonizing Health}

Throughout the twentieth century, the Faith movement mirrored evangelicals and Pentecostals as they increasingly accepted medicine, holistic remedies, and, to a limited

\footnotetext{
${ }^{50}$ Harrison, Righteous Riches, 64.
} 
degree, psychology as methods of divine healing. ${ }^{51}$ Most teachers, black and white, displayed an increasing comfort with medicine as part of God's divine plan for human health.

Oral Roberts paved the way for a broader Pentecostal acceptance of traditional medicine within the broader framework of divine health. As noted, Faith teachers shared early Pentecostalism's rejection of medical solutions. Though most evangelists roughly equated sickness with demonic interference, Oral Roberts felt the first stirrings of interest in medical solutions in the late 1940s, when he surmised that doctors might be able to "assist nature" in nurturing bodies to health, though he also countered that nothing could be done for those whose "spiritual channels are blocked." ${ }^{52}$ By the early 1960s, influenced by William Standish Reed, a doctor and founder of the Christian Medical Foundation International, Roberts began to formulate a plan to merge traditional medicine and divine healing into one comprehensive cure. ${ }^{53}$ In 1977, Roberts unveiled the blueprints of his City of Faith, a medical complex complete with a towering clinic, hospital, and research center heralded by a sixty-foot bronze sculpture of hands folded in prayer. He envisioned it as a preeminent research facility, where Holy Spirit-filled doctors could surpass secular scientists by rooting out both spiritual and physical causes. His dual commitment to science and divine healing emerged clearly in his understanding of cancer, which he argued had a distinct "spiritual origin" with a particular relationship to demonic powers so much so that he could smell its odorous presence. ${ }^{54}$ Roberts believed wholeheartedly that a breakthrough in cancer research would come through the City of Faith whose doctors, seeing both spiritual and physical causes simultaneously, would be uniquely equipped to cure it. In 1989, the City of Faith

\footnotetext{
${ }^{51}$ Joseph Williams, “The Transformation of Pentecostal Healing: 1906-2006” (Ph.D. dissertation, Florida State University, 2008).

52 Williams, "Pentecostal Healing", 61.

${ }^{53}$ Williams, "Pentecostal Healing", 66.

${ }^{54}$ Williams, "Pentecostal Healing", 69
} 
closed under financial duress. Roberts bravely called the expensive collapse of the City of Faith a completed assignment from God; in some ways he was not entirely mistaken, for the endeavor had signaled the broader shifts of the Faith movement and Pentecostal culture more generally.

Pentecostals faced a choice, explained the historian Joseph Williams, between maintaining their anti-medical stance or choosing "to adapt their methods to fit with the increasingly persuasive evidence of medical efficacy." ${ }^{55}$ Most chose the latter. Gradually, medical intervention became a standard part of charitable giving. Most Faith celebrities, including T. D. Jakes, Eddie Long, Creflo Dollar, Joel Osteen, Paul Morton, Keith Butler, and Joyce Meyer, made medical assistance a significant part of their charitable outreach. In March 2009, for instance, the Spiritual and Medicine Recognition Banquet celebrated Pentecostal Assemblies of the World Bishop Noel Jones's efforts to eradicate HIV / AIDS. Pragmatists at heart, believers increasingly learned to harmonize divine health with the efficacy of medical science.

Throughout the 1960s and 1970s, as the Faith movement warmed to the benefits of science, believers shared the wider culture's growing interest in naturalistic healing, favoring the herbs, dietary supplements, and non-invasive methods of alternative medicine. ${ }^{56}$ In particular, Faith practitioners took up naturopathic healing as a reflection of their confidence in the healing power of God's creation. Doctors rose to prominence on major Christian networks as naturopathic experts on diet and health. Dr. Don Colbert, author of The Bible Cure and What Would Jesus Eat?, graduated from Oral Roberts University School of Medicine and found great success in the Faith movement. Colbert offered detailed biblical exegesis that uncovered "God's nutritional laws,"

\footnotetext{
${ }^{55}$ Williams, "Pentecostal Healing", 71.

${ }^{56}$ James C. Whorton, Nature Cures: The History of Alternative Medicine in America (New York: Oxford University Press, 2004), 245-49. See also Kelly Boyer Sagert, The 1970s (Westport, CT: Greenwood Press, 2007), 8-9.
} 
scriptural truths that foreshadowed (and confirmed) modern scientific breakthroughs. Dr. Reginald Cherry, another Trinity Broadcasting Network favorite, unveiled natural herbs and remedies that helped believers live "God's best." Dr. Jordan Rubin's The Maker's Diet and Benny Hinn's Fruits, Vegetables \& Herbs for Energy, Wellness and Power focused specifically on the healing properties of foods mentioned in Scripture. Crisscrossing between divine and secular authorities, these healers applied biblical remedies to restore followers to spiritual and physical health.

For those reluctant to entrust their health to a doctor's scalpel, the biblical diets and bottled cures of Faith celebrities presented a welcome alternative as followers came to see God's work as inherent in the natural world. In many ways, these interests brought the Faith movement back to their nineteenth-century roots. Alternative medicine-naturopathy, chiropractics, acupuncture, homeopathy, and osteopathy, among others- had appeared in America as a rival to traditional medicine, and these practices were embraced by and entwined into as a medley of metaphysical, scientific, and evangelical healing practices. Pentecostalism and metaphysical religion, as twin gospels of health during the first half of the twentieth century, shared an affinity for spiritual alignment with God and a rejection of the heavy materialism of traditional medicine. ${ }^{57}$ When the 1960 s counterculture and the 1970s "holistic" healthcare movement pressed natural medicine and its metaphysical assumptions to the fore, Faith believers rediscovered naturalistic medicine as a like-minded reflection of its own mandate.

In this climate, fasting regained its distinction as a biblical means of attaining divine health and a stronger measure of spiritual power. The evangelist Franklin Hall first popularized the health benefits of fasting in the late 1940s with his bestselling

\footnotetext{
${ }^{57}$ Williams, "Pentecostal Healing", 73-74.
} 
manual, Atomic Power With God Through Fasting and Prayer. After Hall, every major figure of the postwar healing revivals, including Oral Roberts, Kenneth Hagin, and T. L. Osborn, took up Hall's method of ridding the body of spiritual and physical toxins by limiting food intake. ${ }^{58}$ In fasting, believers found a porthole to blessings, as the process promised a leaner, healthier body as well as new supernatural opportunities. ${ }^{59}$ Marilyn Hickey made fasting a centerpiece of her ministry with The Power of Prayer and Fasting, a twenty-one-day model to release protection, plenty, health, and happiness. By 2009, Jentezen Franklin of Atlanta's Free Chapel had become the primary authority on fasting. His New York Times bestseller Fasting promoted the "Daniel Fast," a whole-grain partial fast guaranteed to release the floodgates of God's promises that "can't be released any other way." ${ }^{60}$ Testimonials of healing, job promotion, and supernatural favor filled his Web site as evidence of the material and heavenly potency in fasting. As an extension of Franklin's "first fruits" theology, he heightened the effectiveness of corporate fasting by reserving it for January. He explained, "if we will pray and seek God and give Him our best at the first of the year, He will bless our ENTIRE year!" ${ }^{61}$ Sacred time compounded power upon power.

Ever entrepreneurial, some celebrities promoted health products of their own, offering their own health and fitness as inspiration. Pat Robertson developed "Pat's Diet Shake," a nutritional supplement and accompanying weight loss program that reportedly 720,000 ordered for its promise to “lose weight, never feel hungry, improve your health, gain confidence, and brighten your outlook." ${ }^{62}$ In 2006, Randy and Paula White, co-pastors of Tampa's Without Walls International megachurch, marketed

\footnotetext{
${ }^{58}$ Williams, "Pentecostal Healing", 100, 139.

59 See, for example, Dave Williams, The Miracle Results of Fasting: Discover the Amazing Benefits in Your Spirit, Soul, and Body (Tulsa: Harrison House, 2004), 5.

${ }_{60}$ Jentezen Franklin. http:/ / w ww.jentezenfranklin.org/ content/view/43/153 / (accessed November 17, 2009).

${ }^{61}$ First Fruits Fast at Jentezen Franklin's Free Chapel, Atlanta, http: / / ww w.jentezenfranklin.org/fasting/index.php (accessed November 18, 2009).

${ }^{62}$ Pat's Diet Shake. www.patsshake.com (accessed November 17, 2009).
} 
Omega XL as a life-changing dietary supplement. ${ }^{63}$ Similarly, James Robison, author of True Prosperity, promoted TriVita vitamins in infomercials and on his popular television program "Life Today." ${ }^{64}$ Bishop Jack Wallace of the 9,000-member Detroit World Outreach, along with fitness competitor Randy Woody, founded Prosperity Nutrition, a line of muscle building and meal replacement merchandise.$^{65}$ Employing spiritual language, their "Inferno" products promised to help fat supplies meet an untimely end. For the Holy Spirit-filled doctors featured on TBN, INSP, CBN, and other major Christian networks, this entrepreneurial venture followed as naturally as prescriptions. These health experts sold their personalized products with ease. Dr. Reginald Cherry, host of "Doctor and the Word," founded Abundant Nutrition to sell a host of weight and health management pills, billed to improve memory, weight, sleep, menopause, and even virility. ${ }^{66}$ Though immersed in the science of healthy living, Faith teachers still maintained that what people truly needed was a mental change. In promoting his diet shake, Pat Robertson reminded readers "there's no reason to 'perish for lack of knowledge.' My hope and prayer is that you'll find a healthier and more joyful life, fit for the Kingdom and the Master's use." As Bishop Wallace aptly summarized, these prosperity health products offered "science integrated with wisdom."

America's diet and fitness culture captured the religious imaginations of conservative Christians of all stripes, but none seemed more prepared to evaluate obesity on spiritual terms than the Faith movement. As believers turned to their own bodies for evidence of Faith, modern fitness ideals opened up a new standard against which people could measure their own spiritual progress. Teachings on food and exercise dripped with judgment as the sins of obesity piled up: gluttony, bondage,

\footnotetext{
${ }^{63}$ Michael Sasso, "Preachers of Profit," The Tampa Tribune, May 14, 2006.

${ }^{64}$ James Robison, http: / / www.jamesrobison.com/trivita/' (accessed November 17, 2009).

65 Prosperity Nutrition, http: / / www.prosperitynutrition.com/aboutus.htm (accessed January 3, 2008).

${ }^{66}$ Reginald Cherry, http://www.drcherry.com/ (accessed November 17, 2009).
} 
idolatry and moral weakness. Frances Hunter's work put the problem starkly: “God spoke very loud and clear and I almost fell off the rostrum. He said, 'Fat Christians are the biggest liars of them all-and you're a FAT Christian.'" ${ }^{67}$ Body fat advertised the moral dysfunction. Only the bold attempted to counter fat with the immediacy that characterized miraculous healing. A. A. Allen, for example, famously claimed that a "fat sister" lost 200 pounds before his eyes at a healing crusade. ${ }^{68}$ Most limited their interventionist language to sudden change in appetite, as Frances Hunter explained the miracle: “HE COMPLETELY TOOK AWAY MY DESIRE FOR FOOD!" ${ }^{69}$ Yet as all physical imbalances could be traced to a demonic cause, Faith teachers found deliverance-the binding and loosing of spiritual forces-to be the most useful interpretive framework. Numerous manuals sought to isolate the demonic cause of fat. T. D. Jakes's Lay Aside the Weight encouraged believers to unburden themselves of the generational curses that kept families fat and unsatisfied, offering his own hundredpound weight loss as inspiration. ${ }^{70}$ Frances Hunter argued that Satan might tempt believers in the guise of a cake, pudding, or a candy bar, arousing sinful desires of the flesh that people must "loose" in order to "lose." J1 Joyce Meyer's Eat \& Stay Thin encouraged people to listen closely to the Holy Spirit to guide them daily to rewarding food choices. ${ }^{72}$ "Toss out the tempters!" declared the second commandment of Paula White's Ten Commandments for Health and Wellness, as she implored readers to repent of their sins and empty their pantries of sweets. ${ }^{73}$

Positive confession served at deliverance's right hand. Confessions tailor made

\footnotetext{
${ }^{67}$ Frances Hunter, God's Answer to Fat: Loose It (Houston: Hunter Ministries, 1976), 64.

${ }_{68}$ Alverster Williams, "I Lost over 200 Pounds When I Used God's Reducing Plan,"' Miracle Magazine 6, no. 12 (1961), 3.

${ }^{69}$ Hunter, God's Answer to Fat, 24-25.

70 T. D. Jakes, Lay Aside the Weight: Taking Control of the Weight Before It Takes Control of You (Tulsa: Albury Publications, 1997), 18-19.

${ }^{71}$ Williams, "Pentecostal Healing", 160.

72 Joyce Meyer, Eat E Stay Thin: Simple, Spiritual, Satisfying Weight Control (Tulsa: Harrison House, 1999), 77.

${ }_{73}$ Paula White, Ten Commandments for Health and Wellness (Tampa: Paula White Enterprises, 2007), 39-53.
} 
for weight loss lingered in every detail of nutrition, exercise, and healthy living, promising to strip speakers of demonic interference. Creflo Dollar prompted followers to repeat "Jesus is Lord over my eating habits!" to activate the forces of Faith. Bill Winston, pastor of the 19,000-member Living Word Christian Center in Forest Park, Illinois, published a detailed confession:

I come out from among foods that deplete my body of essential nutrients. . . I exercise regularly and my body is strong and limber, has excellent muscle tone and endurance. . . . I keep my body under and do not allow my flesh to control me. I cancel all destructive cravings for food and substances that threaten my health and well being. I speak to all junk food that comes into my presence. I decree that you have no power to control my desires or my appetite. I am free from bondage to unhealthy food products. ${ }^{74}$

By the late 1990s, most celebrities balanced the language of deliverance with nutritional and fitness advice. White co-wrote her weight-loss guide with personal trainer Dodd Romero, dividing each chapter into practical then spiritual recommendations. Joel Osteen's Healthy Living series devoted as much attention to his fitness regimen as to his divine principles of weight loss. ${ }^{75}$

Many blended this physical, rather than metaphysical, approach with institutional solutions. In 1976, Oral Roberts instituted sharp measures at Oral Roberts University to ensure that all students overcame sinful gluttony and shed unwanted weight. ${ }^{76}$ Students who failed to keep their body fat percentage below the university's standards (20 percent for women, 15 percent for men) would face disciplinary measures. Other institutions simply opened fitness centers of their own. While T. D. Jakes, Willie George, and others promoted their state-of-the-art facilities as another opportunity for parishioners to become involved, some touted their gyms as a place to

\footnotetext{
${ }^{74}$ Bill Winston Ministries, http:/ / ww.bwm.org/training_for_reigning/confession.htm (accessed November $18,2009)$.

75 Joel Osteen, Healthy Living: Discover God's Plan for a Stronger, Happier, Younger Looking You! (Houston: Joel Osteen Ministries, 2006).

${ }^{76}$ Williams, "Pentecostal Healing", 117.
} 
further spiritual excellence. Eddie Long played with images of biblical strength with his Sampson's Health and Fitness center, advertised by a sculpted Samson breaking the temple columns. ${ }^{77}$ Creflo Dollar's World Changers Ministries Body Sculpting Center put a finer point on it, promising to assist people in "achieving a body that is fit for the Master's use." ${ }^{78}$ Pastors commonly detailed their own weight and fitness successes. Joel Osteen appeared on the June 2008 cover of Health $\mathcal{E}$ Fitness Sports Magazine as a featured "fit father" with his son Jonathon. Paula White's Ten Commandments for Health and Wellness included personal workout video, featuring the pastor in a spandex top and pants modeling a full-body strength and cardiovascular workout. Bishop Jack Wallace advertised his ability to bench press 500 pounds with illustrative photos of his peak physical condition. Only a decade earlier, Faith believers would have objected to seeing pastors in scanty tops and shorts, bouncing across the television screen with dumbbells or perspiring in the midst of jumping jacks. Aerobics expert Pamela Cole starred in TBN's "Get in Shape" in the 1980s in a full-body leotard modestly covered with a conservative blouse and skirt. ${ }^{79}$ But modern prosperity believers knew the power of living examples, those whose Midas Touch encouraged them to re-imagine their lives (and bodies) as God's worthy temples.

\section{(Super)natural Health Care}

After the eleven-o' clock Sunday service, I picked up a Starbucks latte in the wide-mouthed lobby of Springs Church, a 10,000-member congregation in Winnipeg, Manitoba, and wandered into the reception area designated for first-time visitors. Jake and Linda, a middle-aged Mennonite couple, greeted me warmly. As we chatted about

\footnotetext{
77 Sampson's Health and Fitness, http:/ / www.newbirth.org/samsons / (accessed November 17, 2009).

${ }^{78}$ World Changers Ministries Body Sculpting Center, http://www.worldchangers.org/Body-Sculpting.aspx (accessed November 17, 2009).

${ }^{79}$ Dennis Roberts, “Trinity Broadcasting Network: The Dream Almost Didn't Happen,” Charisma, June 1983, 23.
} 
my project and our shared Mennonite heritage, Linda began to explain how they had applied Springs' teachings on divine health to their family's own difficulties. Their daughter suffered six miscarriages before the family decided to switch spiritual strategies. Rather than pray for their daughter's ability to carry the children, they decided to pray instead for the "seed" inside her; meanwhile, the would-be mother scoured the Bible for verses about children as a basis for positive confession. After another miscarriage, the doctors discovered that a genetic incompatibility caused her body to reject her pregnancies. With new treatment, she bore three children in a row. Linda smiled triumphantly as she declared it a miracle, brought about by the renewed focus of their prayer. For Linda, her daughter's medically based diagnosis and recovery did not undermine the spiritual causes and cures at play.

Testimonies like these demonstrate not only the persistence of underlying spiritual readings of health and sickness events, but also the kind of bilingualism that frames these accounts as people simultaneously acknowledged that two intersecting processes-medical and miraculous-were at work. A churchgoer recovers in the hospital from a car accident and the church declares it a miracle. Lindsay Roberts, Oral Roberts's daughter, claimed miraculous healing from tumor in her breast, but also went on to publicize breast cancer on her television show “Make Your Day Count." ${ }^{80}$ Did this admission dilute the concept of the miraculous? "We're Faith people," said VFC's First Lady with an upturned chin. “We look at the doctor and say 'You do your thing, and I'll do mine'."

Seated before a live taping of Benny Hinn's This Is Your Day! television program, I watched this bilingualism at work. Dr. Braverman, author of Younger You, sat comfortably beside Hinn on the open-air platform as he lectured on weight loss,

\footnotetext{
${ }^{80}$ Scott Billingsley, It's a New Day: Race and Gender in the Modern Charismatic Movement (Tuscaloosa: University of Alabama Press, 2008), 84.
} 
reminding listeners with a wry expression that "fat is for the Lord, not for our buttocks." He smoothly alternated between referring to his approach as "holistic medicine" and "Holy Spirit medicine" as he prophesied that people will soon live much longer, abundant lives: "For it is written, death will flee from us!" Braverman's naturalistic health program, Hinn explained, had been so successful that Braverman canceled all of his patient's bypass surgeries. "A hundred of them, not all," Braverman quickly corrected, but Hinn pressed on in recounting the miraculous effects of everyday foods and spices. The next guest cut an imposing figure as his large frame perched on the stool beside Hinn. The audience took a moment to recognize the internationally renowned Reinhard Bonnke, faith healer and evangelist to Africa. The rough edges of his German accent resonated like a low growl as he dove into a sermon on Pentecost. "Your body is the residential address of the Holy Spirit," he exclaimed to rousing cheers from the audience, "If you desire your fire, then you'd better claim your flame!" The audience that sat in quiet interest for Dr. Braverman now swayed with enthusiasm. "The best pill is the gospel! Any miracle is possible! I'm going to pray and the fire is going to come down now!" he shouted before the tenuous calm of the crowd broke. People pressed forward to the stage and dozens crowded up the steps to the stage, eager to be one of the few that Reinhard Bonnke clutched with his large hands before they fell to the ground in spiritual ecstasy. People spoke of faith and medicine in the same breath, accepting divine health like a spiritual buffet. They took what they liked.

\section{Explanations for Suffering}

How did believers within the Faith movement reconcile their beliefs with the persistence of disease, or, worst of all, death? Funerals served as a perpetual reminder to believers of the limitations of Faith. For the duration of an illness, however intractable, congregants and leaders traded testimonies of sudden recoveries, miraculous 
cures, and God's persistent interventions. Expectations ran high. Pastor Walton, like most contemporary prosperity teachers, frequently reminded believers that God had promised them 70 to 80 years of divine health. ${ }^{81}$ Still, tragedy visited the Victorious Faith Center, although church members would protest that it happened less frequently in their midst than in other communities. Spouses died unexpectedly, children were lost to diseases, or members perished in accidents. Although hardship could be deemed a test, the finality of death revoked any license for retrospective blessing. In a spiritual cosmos dominated by possibility thinking, funerals marked a true ending.

During my time at VFC, Judy, a longtime member in her sixties, suffered from a brain tumor, failed to respond to chemotherapy, and died. Her participation in church life had grown limited, and as her health waned, her visibility in church life also diminished. Privately, the church rallied around Judy's grieving widower, providing him with meals, assistance, and comfort; however, publicly in sermon, song, tithing, or prayer requests, the church passed over her illness and subsequent death in silence. While sickness and death in general proved to be constant topics in church life, her death, other than an announcement of her funeral, received neither positive nor negative acknowledgment. ${ }^{82}$

Four categories of interpreting "failure" emerged from my interviews with members and my ethnographic observations that may contextualize the silence surrounding Judy's death. First, and most commonly discussed among believers, was suspension of judgment. Believers frequently declared themselves unable or unwilling to draw conclusions regarding another person's difficult circumstances. Though the

\footnotetext{
81 "As for the days of our life, they contain seventy years, or if due to strength, eighty years" (Psalm 90:10). For a theological examination of long life in Word of Faith theology, see Paul L. King, Only Believe: Examining the Origin and Development of Classic and Contemporary "Word of Faith" Theologies (Tulsa: Word \& Spirit Press, 2009), 300-308.

82 Healing practices varied widely among African Americans who participated in the Faith movement. For a comparison of traditional and Word of Faith black healing practices, see Williams, "Is There a Doctor in the House?"
} 
physical evidence appeared to confirm a member's spiritual distress, observers chose not to, in their words, "judge." When a soloist's congested voice cracked on the high notes, or a speaker sniffled into the microphone, shouts of encouragement rose from the pews. In all cases, believers continued to cite their unfailing certainty in God's blessings, but refused to apply their conclusions to their neighbor's plight. For example, Victoria, a medical professional in her 50 s, described seeing another church member exiting a discount department store with purchases, including cold medication. Embarrassed, the member immediately confessed to Victoria. Victoria remembered thinking to herself, "I don't care what you have in the bag! I can't [even] see what you have in the bag!" Yet she replied: "I'm not God!" Victoria's silence over her fellow believer's spiritual misstep was rooted in a cultivated humility. As she explained: "I've learned not to judge people. When I see people prostituting, drug addicts, I see it like this: there but for the grace of God go I. It could be me. So I don't judge people. I don't judge people when they're sick. If they're in the hospital, I wouldn't say, 'OH, YOU DON'T HAVE ANY FAITH.' I always say, you don't know what you're going to do if you're put in that person's position." Victoria's career in the medical field frequently allowed her to see fellow churchgoers as they sought out medical (and therefore less spiritual) solutions, and still she declared herself unable, as "not God," to pronounce a critical verdict. In the difficult months that followed the congregation's loss of Judy, the silence implied a similar sense of charity and suspension of judgment.

Second, silence may have carried lingering condemnation. In this Holy Spiritcentered demonization of disease, bodies charted a spiritual territory. Preachers encouraged the saints to examine their own bodies for signs of Satan's triumph over divine health. Any other conclusion appeared to mitigate death's harsh lessons. "A baby dies and a pastor says 'God has a plan,'” Walton said, shaking his head. "No! That 
baby was stolen [by Satan]." ${ }^{83}$ Death meant failure, the failure on the part of the believer to win the spiritual battle against illness. "Your biggest enemy is not Satan! It's yourself," Walton preached weekly. ${ }^{84}$ Further, since Faith theology taught that healing was granted once-and-for-all, some ill saints avoided or were discouraged from asking for continued help because it might identify them as faithless. For example, members typically asked for public prayer for others, or waited until a triumphant testimony before acknowledging an illness and its subsequent healing. In contrast to the black church's historical position of solidarity with a suffering Christ, believers chose a onceand-for-all Savior and ensuing silent illnesses rather than face public shame. ${ }^{85}$

Third, contrary to church teaching, some believers quietly concluded that illness could portend righteous suffering. Although the saints expected that their faith would be measured in their bodies as reflected in their personal health, some would not blame themselves for the evidence stacked against them. Suffering believers referred often to Job, where they found a righteous man who suffered without blame. Ruth, who taught Sunday school from a wheelchair, described her predicament as a "Job moment." Setting aside the hard causality between Faith and health, Ruth argued confidently, though not publicly, that her suffering was a difficult test of faithfulness. As her reference to Job implied, her misfortune would eventually dissolve to reveal only empty accusations and a righteous sufferer.

Fourth, some members of VFC questioned the church's teachings that tragedy implicated any individual in failure. In whispers, mutters, or private conversations, some believers struggled with the theodicy attached to personal loss. How could a good God

\footnotetext{
${ }^{83}$ Congregational visit, February 4, 2007.

${ }_{85}^{84}$ Congregational visit, February 3, 2008.

${ }^{85}$ Other theological explorations of the Faith movement have made similar critiques. As D. R. McConnell argued in A Different Gospel (Peabody: Hendrickson Publishers, 1988,166), "The time when a dying believer needs his faith the most is when he is told that he has it the least... Perhaps the most inhuman fact revealed about the Faith movement is this: when its members die, they die alone." See also King, Only Believe, 301; Hank Hanegraaff, Christianity in Crisis (Eugene, OR: Harvest House, 1993), 259-60.
} 
allow suffering? Or, in this case, how could any church heap condemnation on tragedy? Public silence muted public grief, creating friction between some churchgoers and the church itself. As an ethnographer, I often heard these complaints framed as an example of overcoming the negative confession of others, as members recalled their dealings with fellow believers who expressed doubt, anger, or frustration. In an environment where speech acts were closely monitored and controlled, parishioners rarely disagreed openly with the church's teachings.

Within Faith communities, the multiple interpretations of the meaning of suffering often yielded silence. The silence may have reflected a breakdown in spiritual vocabulary to express the inexpressible, that God had somehow failed, or that a loved one had also. In the intimate and totalizing spiritual environment of a Faith church, where each member's health, wealth, and circumstances stood on display, the ambivalent silence might simply have allowed for a deep breath, a little space that mitigated the anxiety of revealing both the good and bad that unfolded in each person's life.

Sitting between the grieving widower and Ruth's wheelchair on a regular Sunday morning, I listened to Pastor Walton preach against resigning oneself to death. As the sermon detailed God's promises to provide perpetual health, Pastor Walton seemed convinced that believers could never meet precisely the same end as nonbelievers. After all, famous faith healers like A. A. Allen and Smith Wigglesworth, Walton reminded listeners, raised the faithful from the dead ${ }^{86}$ In the everyday healing practices of the Faith movement, faith operated as a spiritual guarantee, drawing health and prosperity

\footnotetext{
${ }^{86}$ Smith Wigglesworth, Smith Wigglesworth on Healing (New Kensington, UK: Whitaker House, 1999). Long life was assured by most healing evangelists in 1950s and 1960s. Followers tried to resurrect evangelist Jack Coe when he died suddenly. See David Edwin Harrell Jr., All Things Are Possible: The Healing and Charismatic Revivals in Modern America (Bloomington, IN: Indiana University Press, 1975), 85. A. A. Allen abandoned his vigorous preaching on raising the dead when too many followers sent the bodies of their deceased to his Miracle Valley headquarters in Arizona. See Harrell, All Things Are Possible, 199.
} 
into the lives of people willing to suspend naturalistic explanations for supernatural, Holy Spirit causality. From where I sat, divine health did not always seem plausible. Yet through God, the saints reminded me, all things were possible. 


\section{Chapter Five: Victory}

JEHIVAH NISSI (MY VICTORY)

An electric version of "Amazing Grace" reverberated throughout the Greensboro Coliseum on April 18, 2008, as hundreds of latecomers took their seats. Ten thousand worshippers packed into the stacked oval tiers of the arena, many of whom were visitors to the burgeoning urban center of North Carolina's third largest city. This stadium seemed not so different from Joel Osteen's home church, the refurbished Houston Rockets arena. Churchgoers longing for steeples and peaked roofs would have to make their peace with rippling neon light displays, two-story projected lyrics, and Lakewood's symbol: a towering golden globe in slow rotation. Yet tonight, believers seemed as comfortable with importing church to a coliseum as they did with the dwindling of the guitar solos of John Newton's classic hymn.

A whirl of clicks and blinding flashes lit Osteen's entrance, which he rewarded with a squinting smile. “Good evening!" He thanked the audience for sacrificing their Friday night to join him for a Night of Hope, his 2008 international speaking tour. He surveyed the dark expanse of his audience: "You guys look like victors, not victims, to me!" A rush of applause followed. He implored people to stop dwelling on the negative aspects of their lives, because "our lives follow our thoughts." Those who notice the rainy days or the difficult circumstances will only "draw more negativity into your life. . . It's a decision that we have to make. Don't wait for happiness to fall on you. Just make a decision that you're doing to enjoy your life to the fullest. Everyday you're going to live that abundant life." A cascading piano accompaniment softened Osteen's message into a gentle reminder, as a friend might tell a friend. Osteen offered to open the floodgates of the victorious life, insights into how everyday people could escape the 
everyday grind. It would begin, as the brochure promised, with hope. "We love you guys. I've just been telling our congregation back home and I'm going to declare it over you that 2008 is going to be your best year so far." He paused for the applause to wane. "Well, Joel, what does that mean? You're just up there saying that," he remarked, anticipating any skepticism. “It doesn't mean anything unless you take it in to your heart. This is a seed God's trying to deposit on the inside! Why don't you let God birth some new dreams tonight? Why don't you enlarge your vision? ... It's going to be a year of promotion, a year of increase, a year of favor, a year of supernatural opportunities!"”1 With that, Osteen unveiled a vision of the victorious life, where positive thinking became Christian currency.

Here we take up the third and last characteristic of the American Faith movement: victory. The movement trumpeted a gospel of triumph, believing that no circumstance could stop followers from living in total victory here on earth. Leaders inscribed this indomitable spirit in church titles such as World Changers (Atlanta), Victory World Church (Norcross, Georgia), and Champions Centre (Tacoma, Washington.) Church mottos further guaranteed that opposition would crumble under a believer's sure step. The byline of Fred Shipman's multiracial megachurch in West Palm Beach, Florida said it all-Winners Church: Where Winning is a Lifestyle. ${ }^{2}$

The historian Dale Simmons once said that Keswick "Higher Life" followers saw only three types of people: "the unsaved, the merely saved (who live lives of constant defeat), and the victorious Christian." ${ }^{3}$ We might say much the same about the Faith movement, which set triumph as the perpetual goal of the Christian life. They reasoned that "traditional" Christians survived, while Faith-filled believers thrived. "I reign as a

\footnotetext{
${ }_{1}^{1}$ Conference Visit, Joel Osteen's “A Night of Hope," Greensboro Convention Center, April 18, 2008.

${ }^{2}$ Winners Church. http: / / w ww.winnerstoday.net (accessed January 11, 2010).

${ }^{3}$ Dale H. Simmons, E. W. Kenyon and the Postbellum Pursuit of Peace, Power, and Plenty (London: Scarecrow Press, 1997), 88.
} 
king in my domain in this life through Jesus Christ," declared Kenneth Hagin. ${ }^{4}$ The soaring anthropology of John G. Lake's “God-men” theology pumped confidence into their veins as Faith believers called one another "overcomers," "dominators," and "little gods." The atonement raised humanity to a higher spiritual plane and sealed their destiny as those who inevitably triumphed. "When these truths really gain the ascendancy in us," argued E. W. Kenyon, "they will make us spiritual supermen, masters of demons and disease. ${ }^{\prime 6}$ Creflo Dollar surmised that even the Devil struggled to recognize triumphant believers from Jesus "because we look so much alike!" ${ }^{7}$ The slogan for Impacting Your World Christian Center in Philadelphia aptly summarized the prosperity gospel's startling pledge as "Creating People That Cannot Be Destroyed." ${ }^{8}$ This chapter examines the Faith movement's answer to Osteen's call to be “victors not victims," as believers sought to overcome all obstacles in their lives with Faith and selfmastery. The prosperity gospel promised total victory over crushing circumstances, guaranteeing people the tools to become true conquerors.

\section{Techniques of Triumph}

The procession of victory after victory began with the proper use of principles. Believers lived in a closed spiritual universe ruled by consistent cosmic laws. Yet beyond the basics of sowing and reaping, giving and getting, lay additional rules that calibrated the sacred universe. Responsibility lay at the feet of believers to discover them. Markus Bishop, author of Our Covenant of Prosperity, urged readers to devote their lives to finding out how God's kingdom worked. As Markus Bishop explained, God “is saying:

\footnotetext{
${ }^{4}$ Kenneth Hagin, In Him (Tulsa: Kenneth Hagin Ministries, 2006), 18.

${ }^{5}$ For many teachers, this act lowered Jesus to a humanly achievable level of glory. Believers may become Jesus, rather than follow him. Kenneth Copeland once claimed that Jesus never said he was God, only that Jesus "walked with Him and that He was in [Jesus.] That's what you are doing." Kenneth Copeland, Believers' Voice of Victory, September 1991, 3.

${ }^{6}$ Dale Simmons, E W. Kenyon, 54.

${ }^{7}$ Kelefa Sanneh, "Pray and Grow Rich," The New Yorker, October 11, 2004, 57.

${ }^{8}$ Impacting Your World Christian Center. http:/ / www.iywcc.org (accessed January 11, 2010). 
'You have to discover the operation of My kingdom. Learn how to apply its principles in specific areas of your life. Work the principles and laws of My kingdom and obey My instructions. Then all these things will be added unto you." ${ }^{9}$ In particular, three techniques of binding and loosing spiritual power-agreement, names of God, and angels-became popular means to open the windows of heaven

First, prayers of agreement proved to be one of the most enduring techniques for tapping into the victorious life. "The prayer of agreement is joining your faith with two or three others before God," explained T. D. Jakes's protégé Juanita Bynum. ${ }^{10}$ This notion dated back to the post-World War II revivals (if not before), when evangelists rested on the promise of Matthew 18:19 (KJV) that "Again I say unto you, that if two of you shall agree on earth as touching any thing that they shall ask, it shall be done for them of my Father which is in heaven." Among leaders, revivals could not be scheduled or building foundations laid without the power of agreement. Lay people gathered around to "agree" for a fellow Christian hoping to secure a promotion, car loan, divine healing, or family unity. The scramble in the early 1980s to acquire satellite ministries lent weight to these unity prayers, as leaders orchestrated satellite conferences to join the greatest number of supporters in prayer. These new technologies allowed teachers to harness maximum spiritual momentum in a single moment. In 1982, Kenneth and Gloria Copeland's simultaneous broadcast beamed into 137 American cities so that a projected 500,000 people could pray and take communion together. Robert Tilton's Word of Faith Satellite Network attempted to channel the power (and support) of small churches instead. He offered monthly Success-N-Life seminars and Bible school "live via satellite" featuring the leaders such as Charles Capps, John Osteen, Fred Price, T. L.

\footnotetext{
${ }^{9}$ Markus Bishop, Our Covenant of Prosperity: Crossing the Threshold of Supernatural Abundance (Tulsa: Harrison House, 1997), 69.

${ }^{10}$ Juanita Bynum, Matters of the Heart (Lake Mary, FL: Charisma House, 2002), 202.
} 
Osborn, Marilyn Hickey, Paul Yonggi Cho, Kenneth Copeland, and Norvel Hayes. ${ }^{11}$ This practice added a communal facet to an otherwise individualized movement, as followers learned to rely on one another to bring their spiritual plans to completion. Of course, the presence of others brought a new set of problems, as adherents worried that their prayers might be undercut by another's disbelief. If the best-laid plans failed, prayers of agreement sometimes soured believers' faith in one another. A Christian mock-article entitled "Couple Claims Opposing Promises" about a husband and wife purposefully canceling out each other's agreement prayers made the point in jest. ${ }^{12}$ You cannot simply agree with anyone, warned Jay, an avid Victorious Faith Center (VFC) churchgoer and a retail owner whose good looks attracted female prayer partners. ${ }^{13}$ Protocol (and common sense) dictated that members should choose same-sex allies whose spiritual lives were above reproach.

Second, the names of God provided a consistent source of strength and safety. As ever, Jesus' name remained paramount. The popular tune by Lakewood singer Martha Munizzi reminded worshippers of its authority:

Jesus, Jesus

Jesus, Jesus

He's gonna make a way when you say ...

Say the name of Jesus, say the name of Jesus. ${ }^{14}$

Drawing from Oneness Pentecostal practices, followers typically used Jesus' name as a breaking power, one that severed demonic ties and fastened believers to the power of the cross. ${ }^{15}$ Yet adherents turned to other names of God for a way to live the

\footnotetext{
${ }^{11}$ Howard Earl, "Tuning in on New Technologies That Communicate the Gospel," Charisma, June 1982, 3438; Steven Lawson "Uplinking the Gospel: What's Happening With Satellite Ministries," Charisma, December 1985, 62-65.

12 "Couple Claims Opposing Promises," Lark News, August 2007, http: / / www.larknews.com/august 2007 / secondary.php?page=3 (accessed January 13, 2010).

${ }_{13}$ Congregational Visit. Victorious Faith Center, Durham, NC. March 16, 2008.

${ }_{15}^{14}$ Martha Munizzi. "Say The Name." Sony Recordings, 2002.

${ }^{15}$ In using Jesus' authority over demonic powers, believers retained the Pentecostal practice of "pleading the blood." It referred to the blood of Jesus (shed on the cross) as commensurate with atonement power. See Kenneth Hagin, The Precious Blood of Jesus (Tulsa: Kenneth Hagin Ministries, 1984), 27.
} 
victorious life. Creflo Dollar's multi-volume series on the names of God introduced readers to Jehovah M'Kaddesh (Our Sanctifier), Jehovah Nissi (Our Banner), Jehovah Rophe (Our Healer), Jehovah Tsidkenu (Our Righteousness), and Jehovah Shammah (The Ever-Present One. ${ }^{16}$ These names revealed a facet of God's character and, through positive confession, allowed believers to apply God's power to their unique circumstances. Bridget Hilliard, co-pastor of Houston's New Light Christian Center, advertised that her book, My Strong Tower: Power in Knowing the Names of God, allowed readers to "achieve victory through applying the names of God to work in your situations." 17

Third, adherents discovered angels to be necessary companions to a life of total victory. "I found this secret several years ago," confided Angels author Charles Capps, “The Angels are waiting for you to say things that will loose them!"18 In a tightly bound system of cause and effect, the presence of ministering angels, assigned to each person, seemed an unusual addition. Faith, after all, operated as a power without personality, as impersonal as gravity. Yet the prosperity gospel retained a thoroughly Pentecostal cosmos peopled with demons, angels, and spiritual forces caught up in worldly affairs. Angels, bound to Faith-filled words, moved about in the material world to bring believers' words to completion. Most Faith teachers agreed that God assigns every Christian an angel to "watch you and your family." ${ }^{19}$ They assisted in mundane matters such as lost car keys and not-so-mundane matters such as life-threatening emergencies. Pastor Walton of the Victorious Faith Center remembered an angel lifting him in his

\footnotetext{
${ }^{16}$ Creflo Dollar, Jehovah Rophe (Atlanta: Creflo Dollar Ministries, 2000); Creflo Dollar, Jehovah Nissi (Atlanta: Creflo Dollar Ministries, 2000); Creflo Dollar, Jehovah Tsidkenu (Atlanta: Creflo Dollar Ministries, 2000); Creflo Dollar, Jehovah Shammah (Atlanta: Creflo Dollar Ministries, 2000); Creflo Dollar, Jehovah M'Kaddesh (Atlanta: Creflo Dollar Ministries, 2001).

${ }^{17}$ Bridget Hilliard, My Strong Tower: Power in Knowing the Names of God (Houston: Hilliard Ministries, 2009).

${ }^{18}$ Charles and Annette Capps, Angels (Tulsa: Harrison House, 1984), 94.

${ }^{19}$ John Osteen, Unraveling the Mystery of the Blood Covenant (Houston: John Osteen Publications, 1987$), 45$. Benny Hinn, Kenneth Copeland, Gloria Copeland, Marilyn Hickey, John Osteen, and Kenneth Hagin, among others, promoted angels as a significant aspect of living victoriously.
} 
wrecked car from the train tracks, moments before the oncoming train would have crushed him. ${ }^{20}$ In particular, angels served as harbingers of prosperity. ${ }^{21}$ They crossed the bridge separating heavenly and earthly realms, able to bring money from spoken words to a believer's pocketbook. Creflo Dollar's "Angel Power Confession" urged readers to loose angels to "bring my prosperity in my spirit, in my home, in my body, in my family, and in my finances." ${ }^{22}$ Misfortune visited the careless or doubtful, as angels could not protect those who gave negative confession. The presence of these cosmic personalities added a cog to the wheel of things that turned Faith to reality.

What could not be identified as a spiritual principle fell under the expansive category of "favor." The Florida evangelist Paula White explained favor as that feeling that "He is 'on your side,' that He is making a way for you." ${ }^{23}$ It was that intangible quality that outsiders might simply call "luck." Favor attached itself to those doing God's will and transformed their lives for the better. Testimonies at the close of VFC services brimmed with accounts of favor as churchgoers credited God for the blessings of the week. When a middle-aged man testified that his boss gave him a gas card and the company car to visit his ill father, whoops and cries of "favor!" broke out across the sanctuary. ${ }^{24}$ The world, it seemed, stepped aside for the triumphal parade of believers. As the famous gospel ensemble the Clark Sisters sang about overcoming odds, the extraordinary good fortune of believers can be explained by no other reason: "Just know that we're blessed and highly favored." ${ }^{25}$ Seasoned Faith believers would respond to "How are you?" with "I'm blessed and highly favored." Jacqueline Jakes, the First Lady

\footnotetext{
${ }^{20}$ Interview. Victorious Faith Center, Durham, NC: February 3, 2007.

${ }^{21}$ Marilyn Hickey, Your Miracle Source (Tulsa: Harrison House, 1982), 75; Kenneth E. Hagin, The Biblical Keys to Financial Prosperity (Tulsa: Kenneth Hagin Ministries, 2005), 58, 70.

${ }_{22}$ Creflo Dollar. "Angel Power Confession," http: / / www.creflodollarministries.org/BibleStudy / DailyConfessions.aspx?id=2 (accessed January 10, 2010).

${ }_{23}^{23}$ Paula White, Birthing Your Dreams: God's Plan for Living Victoriously (New York: Thomas Nelson, 2003), 24.

${ }_{24}^{24}$ Congregational Visit. Victorious Christian Center, Durham, NC: February 17, 2008.

${ }^{25}$ Karen Clark Sheard, "Blessed and Highly Favored." One Last Time. EMI Gospel, 2007.
} 
of the nation's eleventh largest church, penned God's Trophy Women: You are Blessed and Highly Favored to inspire women to reach for extraordinary goals. ${ }^{26}$ It explained why some prospered while others languished. Favor, argued believers, spun the straw of their lives into gold.

From the few endowed with favor, God expected excellence. Joel Osteen, leader of America's largest church, became the most popular prophet of achieving "God's Best." “God didn't create any of us to be average," explained Osteen, "we were created to excel." ${ }^{27}$ He hoped to inspire followers to climb to great spiritual heights rather than live out the middling lives of those "condemned to mediocrity." ${ }^{28}$ Excellence served as the watchword of prosperity megachurches, each claiming to be ruled by a "spirit of excellence." The best-selling author T. D. Jakes called mediocrity a Christian "addiction" and a "terrorist threat" that demanded a spiritual recovery. ${ }^{29}$ Without a cure, Christians would remain tragically ordinary. Books such as John Avanzini's Financial Excellence, Paula White's Move On, Move Up, and Eddie Long's Called to Conquer testified to the movement's call to press toward perfection. Even children at Joel Osteen's Lakewood Church learned the gospel from the ministry mascot "Champ." With four arms, antennae sprouting from his head, and tennis shoes, he served as a friendly reminder of the church's maxim to "Discover the Champion in You."

The high calling of the prosperity gospel frequently translated into heavy church commitments, as congregations expected their members to apply their newfound excellence to God's kingdom. It fostered a culture of learning that demanded eagerness and attention. Much like New England congregational churches, whose straight-backed

\footnotetext{
${ }^{26}$ Jacqueline Jakes and T. D. Jakes, God's Trophy Women: You are Blessed and Highly Favored (New York: FaithWords, 2006).

${ }^{27}$ Joel Osteen, Become a Better You: 7 Keys to Improving Your Life Every Day (New York: Free Press, 2007), 109.

${ }_{29}^{28}$ Joel Osteen, Your Best Life Now: 7 Steps to Living at Your Full Potential (New York: Faithwords, 2004$), 3$.

${ }^{29}$ T. D. Jakes, Reposition Yourself: Living Life Without Limits (New York: Atria Books, 2008), 21, 95-96.
} 
pews brought the classroom to the meeting house, Faith churches encouraged attendees to bring not only Bibles but also pens and paper for taking notes. Creflo Dollar's World Changers church required members to become "spiritually employed," finding volunteer positions inside church walls. From traffic attendants to choir members to "bathroom ministers," church offices required diligence. ${ }^{30}$ The ambitious visions of most Faith congregations placed strong bids for believers' time, money, skills, and attention. Members, observed the sociologist Milmon Harrison, often found it difficult to make time for activities outside church walls in a religious culture whose demands might seem "all-consuming and overwhelming." ${ }^{31}$ In some ways, this requirement became a natural consequence of the "Full Service Church," a congregation teeming with opportunities for music, dance, counseling, education, sports, fellowship, and social services. ${ }^{32}$ More programs led to a greater need for volunteers.

Yet the Faith movement's culture of expected excellence also extended to small churches like the Victorious Faith Center. Total victory required total commitment. When Joan, a well-dressed teacher in her forties, told me that her sister was also a VFC church member, she quickly added: "But she only comes every Sunday." ${ }^{33}$ To Joan and other dedicated prosperity churchgoers, the victorious life required more. Sunday morning attendance met the lowest standard of participation. Further, few excuses warranted an absence from church. Sickness signaled an attack from the devil that must be met with more church. Working folks should know that further prayer and discipline generated the divine wealth required to give up working double shifts. "We try to be here whenever the doors are open," explained Brenda, bouncing her grandchild on her lap, "Nothing

\footnotetext{
${ }^{30}$ Stephanie Y. Mitchem, Name It and Claim It? Prosperity Preaching in the Black Church (Cleveland: Pilgrim Press, 2007), 76-77.

${ }^{31}$ Milmon Harrison, Righteous Riches: The Word of Faith Movement in Contemporary African American Culture (New York: Oxford University Press, 2005), 129.

${ }^{32}$ Anne C. Loveland and Otis B. Wheeler, From Meetinghouse to Megachurch: A Material and Cultural History (Columbia: University of Missouri Press, 2003), 180.

${ }_{33}$ Congregational Visit. Victorious Faith Center, Durham, NC: March 24, 2008.
} 
else to do but serve the Lord!" ${ }^{34}$ Brenda seemed to have plenty of other things to do. She sat beside me in scrubs from her shift at the hospital, as she had no time to change between work, dinner, and babysitting. Exasperated notes such as "All I do is go to church!" dotted my ethnographic journals, as church attendance engulfed 10 to 15 hours per week. I pressed consultants for answers. "How do you manage to fit it all in?" I wondered and heard their firm reply: I had it backward. Everyday life fit in the margins of church participation, and God intended it that way. Ruth, seated beside me in her wheelchair, explained how she approached services with anticipation for the spiritual breakthroughs awaiting her. She had six days to prepare for Sunday, and she used them wisely.

To be sure, not all churchgoers approached worship with such vigor. Milmon Harrison observed that the high expectations of prosperity believers led people to adopt coping strategies, "exhaust valves" in an environment that tightly monitored speech and behavior. Some filtered the Faith message (selectively accepting or rejecting aspects of church teaching), vented to trusted associates, took a break from involvement, or left the congregation altogether. ${ }^{35}$ Disillusioned participants complained that the emphasis on spiritual excellence led to a competitive atmosphere, as people struggled to meet the strenuous standards set out for them. In a sense, the Faith movement never abandoned the strictures that defined Holiness and Pentecostal culture. Though adherents adorned their bodies with jewelry and clothing that would have turned heads in Holy Ghost circles, prosperity folk pursued holiness with the same single-mindedness. Faith cost.

\footnotetext{
${ }^{34}$ Congregational Visit. Victorious Faith Center, Durham, NC: April 1, 2007.

${ }^{35}$ Harrison, Righteous Riches, 107-129.
} 


\section{Aesthetics of Triumph}

The victorious life began on Sunday mornings, as churches sought to give believers a foretaste of wealth divine. The Faith movement joined fellow church-growth enthusiasts in abiding by Jerry Falwell's maxim that "a cheap church makes God look cheap." ${ }^{36}$ As the megachurch scholars Otis Wheeler and Anne Loveland explained, “believing that 'God deserves our very best' led many evangelicals to underwrite costly facilities featuring luxurious appointments such as plush carpeting and upholstered theater seats, gleaming tile restrooms, expensive woodwork, and the like." ${ }^{37}$ Many achieved spectacular results. Archbishop Earl Paulk's Cathedral of the Holy Spirit employed rich hues and neo-gothic elements to create old-world drama, while Rod Parsley's World Harvest Church revamped a squat brick-and-glass structure with stateof-the-art sound and light displays. Ministries without lavish accommodations occasionally settled for the appearance of wealth. When the religious studies scholar Stephanie Mitchem visited televangelist Leroy Thompson's congregation in Darrow, Louisiana, she found the sanctuary decked in contact paper and spray-painted plastic made to look like marble and gold.$^{38}$ Yet participants might easily have countered that it was simply a form of positive confession. God rewards those who proclaim (and enact) what cannot yet be seen.

The globe replaced the cross as the most common symbol of the prosperity gospel. It communicated two significant aspects of their message. First, it fulfilled the Great Commission's missionary imperative to make disciples of all nations. Kenneth and Gloria Copeland's logo illustrated this point with a world wrapped in the banner, "Jesus

\footnotetext{
${ }^{36}$ Loveland and Wheeler, Meetinghouse to Megachurch, 128.

${ }^{37}$ Ibid.

${ }^{38}$ Mitchem, Name It and Claim It?, 72-74.
} 
is Lord." ${ }^{39}$ Second, it signified spiritual dominion as its leaders sought to lay claim to an international ministry. Hungry for expansion, prosperity megachurches often cultivated a universal image by affixing the label "international" or "world" to their title. ${ }^{40}$ Keith Butler's Word of Faith International Christian Center (Southfield, Michigan) and Jim and Deborah Cobrae's The Rock and World Outreach Center (San Bernardino, California) stood as two examples. Congregations hoisted up flags in their sanctuaries to celebrate every nation home to their ministry.

The sheer size of America's leading prosperity churches symbolized an expansive faith. The cultural analyst Robbie Goh, writing about Australia's 20,000-member Hillsong Church, observed that the megachurch experience reinforced the "performance of the mega." ${ }^{41}$ Prosperity megachurches placed their size at the foreground, reasoning that a bigger church pointed believers to a bigger God. Vaulted ceilings, cavernous sanctuaries, and expansive video monitors defined the space. Pastors appeared to churchgoers as larger-than-life figures. Most prosperity megachurch attenders saw their senior pastor on a huge media screen, knowing him as a public persona rather than a "real person." ${ }^{42}$ Most prosperity leaders of mid-to-large-sized congregations appeared on television or radio, which amplified their reach. ${ }^{43}$ These churches typically found even larger audiences through blogs, podcasts, streaming media, and social networking such as Facebook and Twitter. The megachurch experience reinforced prosperity theology's evidentiary faith and introduced worshippers to an immanent God—seen, heard, and felt in this "'materialization' of the invisible God." ${ }^{44}$

\footnotetext{
${ }^{39}$ Kenneth Copeland Ministries. http:/ / www.kcm.org (accessed January 27, 2010).

${ }^{40}$ Mitchem, Name It and Claim It?, 78.

${ }^{41}$ Robbie B. H. Goh, "Hillsong and 'Megachurch' Practice: Semiotics, Spatial Logic and the Embodiment of Contemporary Evangelical Protestantism." Material Religion 4, no. 3 (11, 2008): 284-304.

${ }^{42}$ Scott Thumma and Dave Travis, Beyond Megachurch Myths (San Francisco, CA: Jossey-Bass, 2007 ), 56-57.

${ }^{43}$ Thumma and Travis, Beyond Megachurch Myths, 56.

${ }^{44}$ Goh, "Hillsong and 'Megachurch' Practice," 295.
} 
The victorious life formed a thoroughgoing imperative. Yet we underestimate the movement if we ignore the totality of its promised triumph. The Faith movement tackled not only individual issues but also larger social and cultural impediments that stood between believers and ultimate victory. We turn now to the prosperity gospel's mixed response to racism and sexism, as adherents oscillated between collective and individual solutions. From there, we examine how believers interpreted the broad sweeps of history, from past sins to the coming apocalypse.

\section{Triumph and Racism}

On a sunny November Saturday, I took my seat in University Park Baptist Church, Charlotte, prepared to hear T. D. Jakes, the famous African American evangelist, in a rare guest appearance in North Carolina. ${ }^{45}$ From the time I parked at the Baptist megachurch to the moment I browsed the bulletin, something seemed askew. Gone were the Sunday hats of African American church fashion. Surveying the thousand people seated, a slow realization dawned: this was business casual. The church greeter, on closer examination, had been an Allstate insurance agent, and the spiritual conference I sought to attend was, in fact, the B.E.S.T. Leadership and Empowerment Seminar. Hundreds of African American entrepreneurs crowded the church to get the B.E.S.T.Black Economic Success Training-and hear a flurry of successful black businesspeople share their stories. Charlotte's speakers included Max Siegal, the first black president of a NASCAR franchise, Glinda Bridgforth, an Oprah-endorsed financial consultant, and Bishop T. D. Jakes, billed as “a beloved pastor, a successful entrepreneur, a global advocate and philanthropist." ${ }^{46}$

Christianity and business acumen twined as the gospel became interchangeable

\footnotetext{
${ }^{45}$ Congregational Visit. Charlotte, North Carolina: November 3, 2007.

${ }^{46}$ T. D. Jakes B.E.S.T. conference series, www.tdjakes.com $/ \mathrm{microsites} /$ best $/$ index.htm (accessed May 4, 2008).
} 
with the business virtues required to get the job done. From the ornate pulpit, Siegal credited loving God as his leg-up on the competitors, while Bridgforth argued that godly self-esteem could be the foundation for solid financial footing. University Park Baptist pastor Claude Alexander Jr.'s short address drew a stronger correlation: God's laws and the laws of business were one and same, as sowing and reaping yielded financial as well as spiritual harvests. Those who placed money in the offering "know we're going to receive," and so must give accordingly. "Plant a seed of faith!" he shouted, and "put away the Washingtons,"-one-dollar denominations would not be enough. As the offertory music swelled, Alexander urged everyone to file past transparent bins the size of garbage cans, so all could see generosity (or scarcity) as it happened.

In spite of the buzz of a thousand eager listeners, Jakes clucked with disappointment as he took the stage. Were this a worship service, he surmised, this place would be packed. Black people want to "dance and shout, but not to learn," he concluded. The fault was not entirely theirs. Traditional Christianity, as it was taught "by slave masters to pacify their slaves," sapped the gospel of its liberating qualities. Jakes enumerated the consequences: only 48 percent of African Americans owned homes, 58 percent enrolled in college, and 25 percent lived in poverty. God promised more. Listeners could seize the Deuteronomic promise that declared God "giveth thee power to get wealth," so long as they would learn, as his latest book was titled, to Reposition Yourself. ${ }^{47}$ His imperative to change yourself, redirect your own thoughts and actions, accepted a model of individual spiritual and psychological change that opposed the dominant voices of a century of African American thought. As part of the legacy of slavery, the black church had long recognized the sway of institutional sin, corporate evil, and preached with an eye toward macro-level injustice and oppression.

\footnotetext{
${ }^{47}$ Deuteronomy 8:18 (KJV): "But thou shalt remember the LORD thy God: for it is he that giveth thee power to get wealth, that he may establish his covenant which he sware unto thy fathers, as it is this day."
} 
Jakes promised largely micro-level solutions: a changed heart, better job, and renewed marriage. "You're an overcomer! Get rid of cancerous thoughts! Don't get sick in your attitudes!" He declared to deafening response, "Every day is a new day!"

As T. D. Jakes' B.E.S.T. conference illustrated, African American Faith teachers adopted a range of solutions for black empowerment. Some assured black believers that they required primarily spiritual tools. The Atlanta preacher Creflo Dollar's The Color of Love: Understanding God's Answer to Racism, Separation and Division argued this position as he diagnosed racism as a demonic force dividing the church. ${ }^{48}$ "The only way to defeat racism," argued Dollar, "is by discovering the foundation for unshakable faith." 49 Dollar rallied believers around the supernatural power of Faith that made each adherent, regardless of color, sons and daughters of acquisition. African Americans should not dwell on the past or seek government restitution for slavery: "You ought to say, 'No I don't want payment from the government. I don't want to say that a man made me rich. I want God to pay me back." ${ }^{50}$ God restored faith-filled black people to their rightful place by spiritual means. The lingering racism of black and white churchgoers, warned Dollar, blocked God's spirit of increase and broke their power of agreement. Dollar promoted a one-on-one model of racial reconciliation; white people must repent of their racism to a black believer, and vice versa. He took his own advice when he and his fiancé, Taffi, adopted a white child.$^{51}$ These micro-solutions to racial reconciliation mirrored the responses of white churchgoers in a study of white and black evangelical responses to racism. The sociologists Christian Smith and Michael Emerson found that white evangelicals' emphasis on individualism and free will led them to see

\footnotetext{
${ }^{48}$ Creflo Dollar, The Color of Love: Understanding God's Answer to Racism, Separation, and Division (Tulsa: Harrison House, 1997), 5.

${ }^{49}$ Dollar, The Color of Love, 22.

${ }^{50}$ Dollar, The Color of Love, 157.

51 Angela Bronner, "The Father of the 'Prosperity Gospel' Talks About Fatherhood," http: / / www.blackvoices.com/black lifestyle/soul spirit headlines features/canvas/feature article/a /which-master-do-you-follow/20060614165609990001 (accessed January 18, 2010).
} 
racism as a problem that stemmed from individuals' prejudices, not structural disadvantages. ${ }^{52}$ So too the dogged individualism of the prosperity gospel predisposed many African American teachers to adopt personal solutions to racism. Rather than dismantle social structures or call for political change, adherents formed cross-cultural friendships or attended a Multicultural Sunday service. Or in Dollar's case, embraced a multiracial family as a perpetual testimony to the power of racial unity.

Teachers like T. D. Jakes offered an entrepreneurial prescription. ${ }^{53}$ Following a robust tradition in African American thought that gave priority to black economic advancement, Jakes attempted to dismantle racism through financial empowerment. He joined many black charismatic leaders who, beginning in the mid-1980s, developed programs to encourage African Americans to own and run their own businesses. ${ }^{54}$ Jakes's B.E.S.T. conferences stood as one of many attempts to rear a generation of black entrepreneurs. Yet unlike Dollar, Jakes focused on the social and environmental causes of inequality, advocating mentorship, education, and opportunity as "great emancipators in the fight for equality." ${ }^{55}$ Jakes questioned the prosperity gospel's rough equation between individualism and victory as he counseled people to seek environments conducive to living a winning lifestyle. Though he stood apart from many prosperity teachers in his indictment of structural sin, Jakes shared their theme of self-reliance.

Frederick Price, centered in Los Angeles's inner city, earned national esteem as an authority on race and poverty. His message to black America promised spiritual

\footnotetext{
${ }^{52}$ In sociologists Christian Smith and Michael Emerson's Divided by Faith: Evangelical Religion and the Problem of Race in America, black and white evangelicals responded differently to racial problems. White evangelicals adopted a gospel of individualism and freewill, predisposing them to approach racial divisions with individual solutions. Individuals must repent and reconcile by cross-cultural friendships. If the problem is individual, the solution too must be individual. It did not occur to most white evangelicals that the problem might lie outside the individual. Black evangelicals, on the other hand, saw racism as a social (rather than individual) problem requiring a corporate solution. Christian Smith and Michael O. Emerson, Divided by Faith: Evangelical Religion and the Problem of Race in America (New York: Oxford University Press, 2001).

${ }^{53}$ For more on the political and social thought of T. D. Jakes, see Jonathan L. Walton, Watch This! The Ethics and Aesthetics of Black Televangelism (New York: New York University Press, 2009), 114-123.

${ }^{54}$ Scott Billingsley, It's a New Day: Race and Gender in the Modern Charismatic Movement (Tuscaloosa: University of Alabama Press, 2008), 107-108.

${ }^{55}$ Jakes, Reposition Yourself, 190.
} 
empowerment and debt reduction, a message that spoke directly to people's needs. Price first reached black audiences across America in 1978 when he bought airtime in four of the largest black urban populations: Washington, D.C., Detroit, Chicago, and New York City. ${ }^{56}$ His ministry began to flourish. Newcomers overflowed in their fourteen-hundred-seat facility, and, by 1981, the church acquired Pepperdine University's downtown campus for \$14 million. In 1986, Price's ten-thousand-seat worship facility - the "Faith Dome" — became the new home of the Ever Increasing Faith services. His unique style broke the mold of 1980 televangelism: he taught for an hour without musical flourishes or appeals for money. Explained historian Scott Billingsley, "Price believed that if people were taught what the Bible said about finances, divine health, and other practical aspects of daily life, they would be inspired to change their lifestyles." ${ }^{57}$ Price's gamble paid off, and this heavily instructional program claimed onethird of all Sunday morning religious programs' audiences. New achievements followed in short order. In 1990, he founded the Fellowship of Inner City Word of Faith Ministries (FICWFM), a parachurch ministry designed to support Faith ministers with urban challenges. By 2007, this network had grown to 300 pastors, who led a combined 150,000 parishioners in 35 states. ${ }^{58}$ He oversaw an extensive Inner-City mission, including Christian education from preschool through high school. A prolific author, Price penned more than fifty titles, totaling more than 2 million copies sold since 1976. His conferences, begun in 1982, drew thousands to his urban crusades, with one event boasting 42,000 in attendance.$^{59}$ By the turn of the century, the Faith Dome housed a 20,000-member congregation and his viewership, largely African American, had climbed to an estimated 33 million.

\footnotetext{
${ }^{56}$ Billingsley, It's a New Day, 111.

${ }^{57}$ Billingsley, It's a New Day, 112.

${ }^{58}$ Harrison, Righteous Riches, 17.

${ }^{59}$ Billingsley, It's a New Day, 112.
} 
Price preached to black audiences, though he worked through white Faith networks, a difference that eventually drew fire. His spiritual mentor, Kenneth E. Hagin, promoted Price among white church networks, giving him a platform for his first charismatic audiences. ${ }^{60}$ Yet these close ties frayed when Kenneth Hagin Jr., in 1992, preached a sermon opposing interracial dating. Price was incensed, and though Hagin Jr. apologized, Price felt that the Hagin family and Rhema Bible Training Center had not publicly opposed racism. Price responded with a theme for the upcoming television year: Race, Religion, and Racism. ${ }^{61}$ This televised series, and accompanying book series, represented Price's most developed thought. Price's three volumes on the subject including, A Bold Encounter with Division in the Church, Perverting the Gospel to Subjugate a People, and Jesus, Christianity and Islam, challenged white leadership to repent of inaction and injustice, while describing Faith theology as the consummation of Christian liberation. He did not mince words: “Don't shake my hand and give a charismatic hug and act as if you love me when you really see me as a nigger." ${ }^{62}$ Racism, he continued, thrived in America with the church's permission. ${ }^{63}$ Black Christians had been denied their God-given power to determine their own destinies: holiness, wisdom, and increase. Price embraced the controversy as a prophetic confirmation: "I believe that the Lord has raised me up for a time like this: to be, as it were, a catalyst to find the solution to what I consider to be America's biggest challenge." ${ }^{64}$ Price successfully linked social injustice to structural racism in the larger context of a highly individualistic gospel. In doing so, he garnered countless admirers, and also inspired a new generation of black charismatic preachers with similar ideas.

${ }^{60}$ Billingsley, It's a New Day, 113.

61 Though Price kept his honorary Doctorate from Rhema Bible Training Center (1976), he removed Kenneth Hagin Sr.'s name from a building named after him on the Crenshaw Christian Center campus.

${ }_{62}$ Frederick Price, Race, Religion E Racism (Los Angeles, CA: Faith One Publications, 1999), 29.

63 Price, Race, Religion, \& Racism, 131.

${ }^{64}$ Billingsley, It's a New Day, 116. 
Racial reconciliation became a perennial theme. Several prosperity teachers, including Jack Hayford, Paula White, Billy Joe Daugherty, and Ron Carpenter, participated in wider Pentecostal attempts to bring unity to their segregated denominations. In October 1994, the Pentecostal Fellowship of North America hosted a racial reconciliation meeting dubbed the "Memphis Miracle" for its progressive attempt formally to unite black and white Pentecostal denominations. ${ }^{65}$ (As ever, a segment of Pentecostals continued to resist prosperity folks' encroachment in this, or any other, matters.)

For the most part, the Faith movement followed the well-established American custom of racial segregation in worship. ${ }^{66}$ Segregated congregations of black, white, and Latino churchgoers remained the norm. Despite this, a new form of multiracial ministry arose in the 1980s and 1990s as prosperity megachurches placed a premium on bridging differences among ethnic groups and attracting potential converts from growing immigrant populations. ${ }^{67}$ Dennis Leonard, pastor of Heritage Christian Center, inspired fellow pastors when he looked out his all-white congregation in Denver, Colorado, and decided to make a change. Leonard replaced their usual music with a gospel choir and implored members to invite Latino and African American acquaintances. "I don't think it's our natural thing to integrate. But I believe it's God's will," argued Leonard. ${ }^{68}$ In 1999, the Full Gospel Baptist Christian Fellowship (FGBCF) ordained Leonard as the first white bishop in their fellowship to oversee multiracial ministries. Lakewood Church also served as a national model. In 2010, Joel Osteen reported that his congregation

\footnotetext{
${ }^{65}$ Vinson Synan, The Century of the Holy Spirit: 100 Years of Pentecostal and Charismatic Renewal, 1901-2001 (Nashville: Thomas Nelson Publishers, 2001), 186.

${ }_{66}$ As Grant Wacker demonstrated, racial harmony never prevailed in Pentecostalism's origins. For a brief summary of Pentecostal racial relations, see Robert Priest and Alvaro L. Nieves, This Side of Heaven: Race, Ethnicity, and Christian Faith (New York: Oxford University Press, 2007), 26-28; Grant Wacker, Heaven Below: Early Pentecostals and American Culture (Cambridge, MA: Harvard University Press, 2001), $226-239$. ${ }^{67}$ I identified 17 prosperity megachurches as multiracial. Most churches dated their founding or rapid growth to the mid-1980s and 1990s when they intentionally cultivated an ethnically diverse ministry.

${ }^{68}$ Eric Gorski, "Sold on the Spirit," http://www.denverpost.com/specialreports/ci 4462706 (accessed January $20,2010)$.
} 
shared equal numbers of people of European, African, and Latin descent. Marcos Witt, winner of four Latin Grammys, joined the congregation in 2002 to lead Lakewood's Hispanic ministry, a popular draw for Texas's burgeoning Latino/ a population. His Spanish services, comprised of first- and second- generation immigrants from Mexico and Central America, stood among America's largest Hispanic congregations. ${ }^{69}$ Israel Houghton, Grammy-winning worship pastor at Lakewood, bridged the black-white divide as one of nation's most high-profile biracial Christian artists, bringing a fusion of gospel, rock, and jazz to Sunday services.

By 2010, prosperity megachurches claimed some of the highest rates of multicultural congregations. Twenty percent of prosperity megachurches boasted a multiethnic congregation. ${ }^{70}$ Latino leaders proved particularly adept at gathering diverse congregations. Latino celebrities included the late John Gimenez, organizer of the 1980 Washington for Jesus rally, the Miami-based Apostle Guillermo Maldonado of King Jesus Ministry (El Rey Jesus), Bishop Jay and Jeannine Ramirez, founding pastors of Kingdom Life Christian Church in Milford, Connecticut, and Pastors Diego and Cindy Mesa of the 5,000-member Abundant Living Family Church in Rancho Cucamonga, California. ${ }^{71}$

Though most prosperity churches did not dismantle racism by integrating congregations, the prosperity gospel offered a compelling alternative to competing visions of race and the victorious life. Black leaders exulted when they snatched followers from Nation of Islam (NOI), and they kept its competing ideology of race in the forefront of their teaching. ${ }^{72}$ Frederick Price devoted an entire volume to Nation of Islam's rival theology of the divine high life. As the historian Kirk MacGregor asserted,

\footnotetext{
${ }^{69}$ William Martin, “Lakewood Church, Servicio en Español,” Texas Monthly, December 9, 2007.

${ }^{70} \mathrm{I}$ found 18 of the 86 prosperity megachuches claimed to have multiethnic congregations. See also Thumma and Travis's "charismatic/pastor focused" megachurches for themultiracial profile of American prosperity churches. Thumma and Travis, Beyond Megachurch Myths, 30-43.

${ }^{71}$ See Appendix 1 for a profile of these congregations.

72 See Creflo Dollar, The Color of Love, 80-95,
} 
Faith and NOI theology offered similar narratives of God-like believers, robbed of legal dominion of the earth. ${ }^{73}$ Latino Faith teachers, like those in the predominantly Latino Maranatha World Revival Ministries in Chicago, Illinois, promoted the prosperity gospel as the new liberation theology. In this reconfiguration of the Catholic-inspired "option for the poor," Maranatha Ministries and other Latino churches like it promised to deliver members from the roots of their oppression, a vision summed up in their motto: “Santidad, Salvación, Sanidad, Liberación (Sanctification, Salvation, Healing, Deliverance)." 74

The swelling ranks of Latino Faith churches demonstrated a potent synthesis of classical Pentecostal and Word of Faith theology drawn and interpreted through Latin American immigrant experiences. In the 1970s, when Latino Pentecostals first gravitated toward Faith congregations and away from classic Pentecostal denominations, these new congregations saw themselves as Faith churches first and Latino second, emphasizing theological over ethnic distinctions. "Those initial Word of Faith expressions," explained the historian Arlene Sanchez Walsh, "did not include much in the way of cultural markers that allowed Latinos to maintain their ethnic identity." A second wave of independent Latino congregations encouraged churchgoers to retain their

\footnotetext{
${ }^{73}$ MacGregor argues that Faith theology took shape by 1995 and that "neither Kenyon, [William] Branham, nor Roberts can be called the source of the core theological anthropology of the contemporary Word-Faith system" (91). He defined Faith anthropology as a) humans made from a "flesh-and-bones" God, b) restored ontologically from the Fall, and c) sharing God's nature. The origins of this anthropology lay in Nation of Islam and Mormonism, traditions prevalent in the same geographic areas (Tulsa, Houston, and Los Angeles) as the developing Faith theology.

Yet MacGregor's late start date for Faith theology overlooks the rich pre-war Pentecostal cosmology that formed the movement's theological foundation. He attributes Price's legal language and "little gods" concept to Nation of Islam, though Faith teachers originally drew these ideas from Kenyon and John G. Lake, respectively. Further, MacGregor identifies the movement's epistemic focus as a fusion of Nation soteriology whereby black people become gods by embracing "accurate knowledge" (99). MacGregor clearly demonstrates the parallelism between the high anthropology of Price and Nation of Islam. He rightly observed that the affinities between Nation of Islam and Word of Faith theology invigorated Price's thinking. Further research comparing Pentecostal uses of "little gods" theology with contemporary Nation and Mormon interpretations may illumine MacGregor's fruitful line of inquiry. Kirk MacGregor, "The Word-Faith Movement: A Theological Conflation of the Nation of Islam and Mormonism?" Journal of the American Academy of Religion, 75, 2007: 87-120.

${ }^{74}$ Arlene Sanchez Walsh, "Santidad, Sanacion, Salvacion, Liberacion: The Word of Faith Movement among Twenty-first Century Latino Pentecostals," Global Pentecostalism, 212-245.
} 
language and culture. In adapting a friendlier approach to ethnic differences, prosperity churches captured wider audiences. A 2008 Pew survey found that 83 percent of Spanish speakers surveyed agreed that God granted financial success and good health to believers, compared with 54 percent of English-dominant Latinos. ${ }^{75}$ The prosperity gospel's results-driven approach effectively competed for believers' hearts and minds against plausible alternatives.

\section{Triumph and Women}

Gloria Copeland commanded the pulpit with Texas gentility-tough spiritual talk draped with a little lace. Her sermon at the March 2008 Branson Victory Campaign trumpeted the blessings of a godly life. The early years of her marriage to Kenneth Copeland brought nothing but poverty, she explained, and she sought the Bible for a solution. Jesus' imperative to "Seek ye first the kingdom of God, and all these things shall be added unto you," struck her as significant. "Things!" she exclaimed, "I was very interested . . I I needed some things!" ${ }^{76}$ In 1962, she converted to Christianity, with her husband soon to follow, and found their material circumstances radically changed. They had experienced the life abundant, and her Branson message promised it to others: "Get in on the good life!"

Gloria Copeland proclaimed what experience and prosperity theology confirmed: the laws of Faith worked for her no less than for anyone else because "God is no respecter of persons." 77 The careers of Maria Woodworth-Etter, Aimee Semple McPherson and, later, Kathryn Kuhlman, Freda Lindsay, and Daisy Osborn made inroads in Pentecostal culture for the acceptance of female evangelists, but progress

\footnotetext{
75 “Changing Faiths: Latinos and the Transformation of American Religion," (2006 Hispanic Religion Survey) http: / / pewforum.org/ newassets / surveys / hispanic/ hispanics-religion-07-final-mar08.pdf (accessed January 7,2010$)$.

${ }^{76}$ Gloria Copeland, Branson Victory Campaign, March 6-8 2008, www.bvov.tv/branson m4v.xml (accessed April 11, 2008).

${ }_{77}$ Acts 10:34 (KJV): “Then Peter opened his mouth, and said, 'Of a truth I perceive that God is no respecter of persons."
} 
came inch-by-inch. ${ }^{78}$ Few churches called a woman to the position of senior pastor or boasted of female spiritual oversight covering their ministry. Like many famous female preachers in the Faith movement, Gloria's career began as a supporting role to her husband's ministry. The couple moved to Oklahoma in the fall of 1966, eager to attend Oral Roberts University, where Kenneth soon came to the ministry's attention. A pilot and former pop singer, his talents suited his new employment as Roberts's pilot, chauffeur, and a touring singer. As Kenneth worked and studied under the auspices of Oral Roberts's famous healing ministry, he became a follower of another Faith giant: Kenneth Hagin. Starting in 1967, Hagin's denominational prosperity teaching, Word of Faith, taught the Copelands a new vocabulary to describe the relationship between belief and materiality. Kenneth Copeland adopted Hagin's understanding of positive confession with such conviction that he offered to trade their car to Hagin's ministry for another set of Hagin's taped teachings. ${ }^{79}$ With Hagin's teachings on positive confession, Oral Roberts's healing ministry, and a developing theology of finances, the Copelands' distinctive brand of Faith theology took shape. Much like Freda Lindsay and Daisy Osborn, whose full partnership in their husband's work often went unnoticed, Gloria took on spiritual responsibilities with limited public exposure. On September 7, 1967, the couple founded Kenneth Copeland Ministries (KCM).

In the 1970s, female Faith teachers gained greater-albeit limited-acceptance in an atmosphere hostile to encroaching feminism. The political and cultural upheavals of the late 1960s and the 1970s ended the evangelical and Pentecostal consensus with American culture. A political and social maelstrom emerged, including African American civil rights, women's rights, and the Vietnam War, as well as the rise of nonmarital sex,

\footnotetext{
${ }^{78}$ Kathryn Kuhlman, the nation's most famous healing evangelist, assumed a prominent place in the charismatic movement but not the Faith movement. Though Benny Hinn famously claimed Kuhlman as his spiritual parent, she neither met him nor espoused prosperity theology.

${ }^{79}$ Billingsley, It's a New Day, 67.
} 
abortion, divorce, and open homosexual practice. Concurrently, women gained better access to health care, birth control, fair wages, and legal rights, changing the social, economic, and legal context of marriage. The divorce rate more than doubled during this period, eroding the centrality of the male breadwinner family. ${ }^{80}$

As they perceived the authority and esteem of the family to be on the decline, many religious conservatives balked at women in leadership in their midst. Daisy and T. L. Osborn returned from their successful international crusades to discover that conservative audiences did not accept the egalitarianism that characterized their ministry. Since 1948, Daisy wrote, "my husband and I have walked together, prayed, fasted and read together, taught and preached together, enjoying the supreme privilege of leading broken, bleeding, and suffering humanity to the feet of Jesus." ${ }^{81}$ Though Daisy was a seasoned speaker, American churches sat her in the front row rather than onstage with her husband. Daisy vowed that she would not attend speaking engagements that did not specifically include her. ${ }^{82}$ In the 1980 s, Daisy organized the hugely successful International Women's Conferences, while her husband taught the accompanying workshop entitled: "How to Assist a Woman in Ministry."

Some women gained leadership the old-fashioned way: proving people wrong. In 1973, Freda Lindsay took over Christ For the Nations after her husband, Gordon, died. Adherents revered Gordon for his central role in the post-war healing revival, but observers soon realized that Freda's behind-the-scenes role had been larger than anticipated. Freda's shrewd business sense and forthright management steered the ministry from shaky financial ground, and she secured her status as a significant leader

\footnotetext{
${ }^{80}$ For an extended treatment of the changing social, economic and political circumstances of American families during this period, see Stephanie Coontz, Marriage, A History: How Love Conquered Marriage, (New York: Penguin, 2006), 261-262.

${ }^{81}$ Billingsley, It's a New Day, 51.

${ }^{82}$ Billingsley, It's a New Day, 50.
} 
in her own right. ${ }^{83}$ So too Gloria Copeland emerged from her husband's shadow. In 1973, the couple founded their ministerial magazine, The Believer's Voice of Victory, and Gloria wrote her first book, God's Will for You. A year later she appeared onstage at crusades. In 1975, their ministry took to the airwaves, and, in 1979, they debuted the Believer's Voice of Victory television broadcast, the engine of the ministry's outreach. The same year construction began on KCM's new headquarters on Eagle Mountain Lake, the 1,516-acre property housing their television studio, production center, and staff offices. ${ }^{84}$ She debuted her public speaking abilities at their first annual Believers' Convention, their sixday conference series and ministerial trademark. Though Kenneth initially took the sole pastoral role, by the decade's close, Gloria's popularity with audiences gave her a ministry of her own. ${ }^{85}$

During the 1980s and 1990s, a handful of celebrated Faith teachers used their influence and popularity to promote women's concerns in American Pentecostal churches. By the mid-1980s, women's leadership conference arose as a fixture of the largest ministries. ${ }^{86}$ Marilyn Hickey, Vicki Jamison Peterson, Tammy Bakker, Evelyn Roberts, Freda Lindsay, Gloria Copeland, Dodie Osteen, and Marte Tilton earned top billing. In the 1990s, Joyce Meyer, Paula White, Juanita Bynum, and Billye Brim joined them at the top. The Faith movement's acceptance of therapeutic paradigms opened up new avenues to address women's mental health. T. D. Jakes rose to fame for his attention to women's emotional healing, a theme that struck market gold with his series, Woman, Thou Art Loosed! His book and his 1993 conferences of the same name addressed the hushed issues of domestic violence, discrimination, rape, and divorce and

${ }^{83}$ Billingsley, It's a New Day, 56-64.

${ }^{84}$ Unknown author. Believers Voice of Victory, Vol. 35, no. 10, (Canadian edition), October 2007, 25.

${ }^{85}$ Billingsley, It's a New Day, 67.

${ }^{86}$ For example, Anne Gimenez founded the International Women in Leadership conference with famous evangelical, charismatic, and Pentecostal speakers crowding the advisory board. 
focused on women's psychological healing. Woman, Thou Art Loosed became a selling phenomenon, with 2 million copies printed copies, record-breaking conference attendance, a play, a gospel album, and a 2004 film adaptation.

Not only did audiences hear more about women, adherents turned to female evangelists as spiritual guides into the spiritual realm of emotion. Women made topics heavy with sentiment not simply acceptable but significant avenues of spiritual growth. Paula White, a self-proclaimed "messed-up Mississippi girl," spoke of how the gospel released her from the wounds of her childhood sexual and physical abuse. ${ }^{87}$ Joyce Meyer told a similar account. Her early life spelled hardship, suffering sexual abuse at the hands of her father and struggling through a soured marriage and divorce in her early 20s. Yet her story of spiritual recovery, retold in the novel The Penny, followed the ragsto-riches trajectory of the Faith message. She preached a gospel of prosperous sanctification, a life improved financially, spiritually, and socially through God's blessings. The victorious life for women was at hand.

Female teachers struggled to maintain reputations as both authoritative leaders and submissive wives. When a reader questioned the famous 1980s evangelist Marilyn Hickey on this issue, Hickey assured audiences that she unflinchingly obeyed her husband. If her husband forbade her traveling ministry, she would stop immediately because "he clearly hears the voice of the Spirit." ${ }^{88}$ When their marriages failed, female evangelists often faced stronger opprobrium than males. When Paula White's marriage to her co-pastor Randy fell apart, disapproval dogged her every step. During her interview with Larry King, an e-mail question from a San Antonio viewer stated it bluntly: "How can you preach from the pulpit regarding marriage when yours failed?"

\footnotetext{
${ }^{87}$ Stephen Hubbard and Lisa Ryan, “Turning Trash into Treasure: the Testimony of Paula White," http: / / www.cbn.com/700club/Guests / Interviews / Paula White063005.aspx (accessed January 23, 2010). ${ }_{88}$ Ask Marilyn. "What Comes First?" Charisma, January 1985, 1. 
White replied that she was committed "never to waste my trials in life, to find purpose in all things," critics were not convinced ${ }^{89}$ Juanita Bynum received heated criticism for divorcing her husband and fellow prosperity pastor Thomas Weeks III even after he was jailed for allegedly assaulting her in an Atlanta parking lot. ${ }^{90}$ Their ministers, observed Scott Billingsley, mirrored the wider American culture's growing commitment to sexual equality while retaining the traditional conservative mores of mother and wife.

Many independent female teachers, whether by principle or pragmatism, positioned themselves under male spiritual leadership. To be sure, evangelists commonly chose the spiritual oversight of respected peers and most pastors were, of course, men. Yet some women chose familial language to describe their personal pastor that underscored their submission. Paula White referred to T. D. Jakes not only as her mentor but her "spiritual daddy," while Juanita Bynum called Jakes, Rod Parsley, and I. V. Hilliard her "fathers-in-the-Lord." ${ }^{91}$ When Bynum and Jakes clashed, she publicly apologized before the thousands gathered at his Woman Thou Art Loosed conference by kneeling before him barefoot and tearfully saying: "You are my spiritual father. I submit to you." ${ }^{92}$ Kenneth E. Hagin in The Woman Question agreed that it was "usually best" to keep gifted men at the helm of churches, but if they could not be found then "let us call the sisters into action." Those women laboring as pastors and evangelists must endeavor to "be content with whatever place the Lord opens" and remain humble, sweet, and faithful. ${ }^{93}$ Anne Gimenez, co-pastor of Virginia's Rock Church and author of the book The Emerging Christian Woman, deplored Christian women's aggression, “arguing for

\footnotetext{
${ }^{89}$ Larry King Live, http:/ / transcripts.cnn.com/TRANSCRIPTS/ 0711/26/lkl.01.html, (accessed January 18, 2010).

${ }_{90}$ Denene Millner, “Juanita Bynum: I've Come This Far by Faith,” Essence, December 2008. See also Shayne Lee and Phillip Luke Sinitiere, Holy Mavericks: Evangelical Innovators and the Spiritual Marketplace (New York: New York University Press, 2009), 109-110.

${ }^{91}$ Stephen Hubbard and Lisa Ryan, "Turning Trash into Treasure: the Testimony of Paula White,"

http: / / www.cbn.com/700club/Guests / Interviews / Paula White063005.aspx (accessed January 23, 2010). 92 A Renewed Covenant, http:/ / www.jellofart.com/a-renewed-covenant-5-juanita-bynum/ (accessed January 23, 2010)

${ }_{93}$ Kenneth Hagin, The Woman Question (Tulsa: Faith Library Publications, 1983), 65-66.
} 
their 'rights,' displacing men, grasping for leadership." ${ }^{94}$ Audiences wanted women to be anointed not aggressive, experienced but not proud. It was a tall order.

From the 1980s onward, most major ministries felt that the best of both worlds lay in husband-and-wife teams. It became ministry's new gold standard for its obvious advantages. Married leaders typically duplicated the traditional order of conservative households, upholding the husband's spiritual oversight but also encouraging women to exercise their own expertise. Creflo Dollar, for example, headlined national tours while Taffi Dollar focused on her own women's conferences. Joel and Victoria Osteen held their interlaced fingers in a triumphant salute at the close of every conference. These married teams assured audiences that the ministry reflected family values, even when wives outshone their husbands. In Joyce Meyer's 2008 speaking tour, she painstakingly defended her husband's authority and support of her ministry, pleading with audiences to attend Dave's early morning presentation on patriotism. ${ }^{95}$ The Faith movement had learned to accept women's contributions to the victorious life, albeit with mixed results.

\section{Triumph and Time}

Benny Hinn leaned into the podium and rolled his eyes. "I don't have to even say it because we are thinking the same thing!" he said, shaking his head. The Dome of the Rock's call to prayer wafted onto the televised setting for Benny Hinn's first address on his Holy Land tour, an unwelcome reminder that thousands of Muslims knelt in Ramadan prayer just over the Jerusalem's city wall where we assembled. Not far away, the cheers of hundreds of Israeli soldiers, dressed in fatigues, yarmulkes, and casually slung assault rifles, marked the commencement of the Soldier's Oaths festivities at the

\footnotetext{
${ }_{94}$ Anne Gimenez, “Taking the Lead From Esther," Charisma, June 1986, 30-34.

95 Conference Visit, Joyce Meyer Conference. Lawrence Coliseum, Winston Salem, NC: March 13, 2008.
} 215 
Western Wall. Unbelievers besieged the Holy City itself, no matter how loudly the crowd attempted to sing "The Old Rugged Cross."

"It won't be like this for long, because Jesus will take care of all of this!" Hinn shouted to the crescendoing crowd. Jesus would return to this very place, Hinn assured us, and we would not have to wait long. Israel's miraculous rebirth as a nation in 1948 marked an explosion of prophecy, truths that God would reveal in a hundred years. Unwilling to bait the crowd with generalities, he named the date: 2048. Jesus would gather up the faithful, the true seekers who believed themselves to be present this night. ${ }^{96}$

As we wandered back to the hotel, a few labored over the implications. "Everything is just coming together!" a man in a Hawaiian shirt exclaimed, while an elderly woman appeared more concerned. She carefully counted and recounted the years between now and then, and tallied it to her age. She would be too late.

Benny Hinn, a Canadian-reared Israeli, stood as one of the world's best-known televangelists and prosperity preachers, famous for his "Miracle Crusades" and international fan-base. In September 2008, 900 believers-and me-followed Pastor Hinn to Israel. Expectations ran high. As "Pastor Benny" proclaimed on this first night, this would be a life-changing experience and a profound encounter with God. Hinn modeled intimacy with God and history as a popular prophet. As the markets fluctuated, the global political climate changed, and the social mood darkened, believers turned to those who interpreted their faith in the context of changing times. Most often, leaders like Benny Hinn set the grand stage for spiritual expectations by constructing timetables for the end of the world or putting the daily news in cosmic context.

In a general sense, every Faith leader took on this role. Often, it translated into general assurances that the spiritual laws of sowing and reaping did not shift with the

\footnotetext{
${ }^{96}$ Benny Hinn's Holy Land Tour, Israel, September 11, 2008.
} 
times. Believers would ascend to greater heights, regardless of circumstances. As Joel Osteen proclaimed on his 2008 speaking tour, "It's going to be a year of promotion, a year of increase, a year of favor, a year of supernatural opportunities!" ${ }^{97}$ Faith teachers frequently declared "the Year of ..." as they received God's revelation for the year to come. In effect, they applied God's spiritual laws to every calendar year. Paula White declared 2008 to be the year of new beginnings, and a start for new supernatural increase. Kenneth Copeland sent out hundreds of thousands of pre-recorded phone messages declaring 2008 the year of the fullness of God's measure. Though critics dismissed this as a gimmick, followers expected their leaders to provide this kind of macro-level eschatological interpretation. It located believers in spiritual time, establishing expectations for how Christians should set their own lives to the cosmic spiritual clock.

A measure of victory lay in the past. The past connected believers to a spiritual bloodline, traceable from the crucified Christ to every child of God. Spiritual lineage superceded natural family background as the new indicator of identity and ability. "You have the DNA of Almighty God," stated Joel Osteen. "You need to know that inside you flows the blood of a winner." ${ }^{98}$ Victory came as a birthright. Why then did sin stubbornly persist? Osteen answered simply: "bad blood." The natural bloodlines flowing through grandparents, parents, and children passed down hereditary sin that perpetuated generational curses. Prudent believers cautiously combed through the past to find the residual effects of their natural family's bloodline. All manner of illnesses and behaviors — especially debt, abuse, alcoholism, and depression—fell under the overarching category of generational curses. Derek Prince, one of the charismatic movement's experts on the subject, likened curses to a "long, evil arm stretched out from

\footnotetext{
${ }_{97}$ Conference Visit, Joel Osteen's “A Night of Hope,” Greensboro Convention Center, April 18, 2008.

${ }^{98}$ Joel Osteen, Become a Better You, 34.
} 
the past." ${ }^{99}$ Seven probable indicators of curses included mental breakdown, chronic illness, barrenness, family alienation, financial difficulties, repeated accidents, and untimely deaths. Adherents learned to look for negative patterns in their lives and root out their spiritual cause. Faith believers applied spiritual solutions to what outsiders might call genetic, social, economic, and environmental causes. Yet prosperity folk would not concede defeat to genetic or social circumstance. As Brenda, a nurse from Durham's Victorious Faith Center argued, people surrender their God-given victory when they repeat "I have this because my daddy had this ..." as a foregone conclusion. Take responsibility! Take control! ${ }^{100}$

On the face of it, two conflicting impulses squared off in prosperity theology. The first was the prosperity injunction to do well on this earth by increasing in measure and deepening in faith. Outsiders often depicted the prosperity gospel as so "worldly," so comfortable with perfecting life on earth, that it lacked the concern with the apocalypse that fueled many other Christians. To Kenneth E. Hagin, this was good common sense: "I'm more concerned about the life that now is than I am about the life that is to come. Because the life that 'now is' is the life I'm living right now." ${ }^{101}$ Though adherents did not want to jettison the promise of heaven, they championed the present as a garden of delights. Second, as prosperity theology was submerged in a broader Pentecostal cosmology, the prosperity gospel anticipated that this world would come to an end. Human life remained a conditional gift, and time would someday unravel. "We are the end-time generation," warned Kenneth Copeland. ${ }^{102}$ So how could the same gospel be

\footnotetext{
${ }^{99}$ Derek Prince, Blessings and Curses (Grand Rapids: Chosen Books, 2003), 8.

${ }_{100}$ Congregational visit, Victorious Faith Church, Durham, NC: March 9, 2008.

${ }^{101}$ Hagin, Godliness is Profitable (Tulsa: Kenneth Hagin Ministries, 1982), 5. In this way, the prosperity gospel reflected the impulses of its metaphysical heritage. As Catherine Albanese observed, metaphysical religion remained grounded in the present. "For ... the new American metaphysics, however, the future was now, and the future was here on earth." Catherine Albanese, A Republic of Mind and Spirit (New Haven, CT: Yale University Press, 2007), 322.

${ }^{102}$ Kenneth Copeland, Dear Partner (Fort Worth, TX: Kenneth Copeland Publications, 1997), 9.
} 
committed to prospering on this earth, and seeing this earth come to an end? In other words, could believing folk maintain a strong stake in the soon-to-be abandoned world and still be committed to the apocalypse?

Faith believers re-conceptualized the traditional Pentecostal narrative of time as laid out in Premillennial Dispensationalism. ${ }^{103}$ This biblical hermeneutic found discrete spiritual principles at work in different historical epochs, and commonly saw the present as an era of cultural and spiritual decline that believers must endure until they were "raptured" (physically taken to heaven while living.) Faith preachers maintained a Pentecostal theology of decline, but exempted believers from having to suffer for it. Gloria Copeland assured audiences that while crime increased, moral decay flourished, and although others suffered, she did not "plan on being with them." ${ }^{104}$ Instead, she would continue to progress financially and spiritually, moving from "glory to glory to glory." Faith believers redefined the notion of rapture. Traditionally, God rescued believers from their problems by taking them to heaven. Instead, God took the problems from the believers, bringing a bit of heaven to them. It fortified a theology of upward mobility, for the wicked world (however corrupt) could never displace believers from victorious living in the present one. All structural sin-including racism, sexism, and poverty-must be placed in the context of this narrative of sweeping confidence. History rewarded the faithful who stubbornly believed that the earth brimmed with opportunities, a sure field for any believer's harvest.

Three prescriptions for the end times prevailed. In the first, God called for individual purity and that virtue would offer the believer safe haven while the world deteriorated. Some teachers went so far as to say that the timing of Jesus' Second

\footnotetext{
103 See also Kenneth Archer, A Pentecostal Hermeneutic for the Twenty-first Century: Spirit, Scripture and Community (New York: T\&T Clark, 2004), 49-57; Glenn Miller, Piety and Profession: American Protestant Theological Education, 1870-1970 (Grand Rapids: Eerdmans, 2007), 179-200.

${ }^{104}$ Gloria Copeland, Azusa Street Centennial General Sessions (CD), (Divide, CO: Kingdom Recordings, 2006). 219
} 
Coming hinged on the progress of individual regeneration. In the second reading, Jesus would not return until the church (taken to mean a local, independent congregation) demonstrated the depth of their Faith. The Victorious Faith Center labored to be the glorious church described in the book of Ephesians as "not having spot or wrinkle" but "holy and without blemish." ${ }^{105}$ Churchgoers should be ready to show the "signs and wonders" accompanying the prosperity gospel, from paid mortgages, to respectable jobs, strong families, and deep faith. Third and last, some prosperity preachers argued that the prosperity gospel operated at a national level. America's future depended its response to God's original Promised Land: Israel.

\section{Triumph in Zion}

Between the tapings of Benny Hinn's television program This is Your Day!, Hinn took off his sunglasses and looked out at the gathered crowd. "It's a beautiful view, isn't it?" he asked, gesturing behind him to the sweeping view of the Old City, Jerusalem, gleaming white over the thoroughfare and steep embankment that separated us. "You know," he continued, "Jerusalem needs our help." Condoleezza Rice, George W. Bush's secretary of state, sought to divide the sacred city among Palestinians and Israelis, threatening not only Israel's future but also God's blessing on America. ${ }^{106}$ "Come up here! Gather around!" Several hundred travelers huddled around the platform and stretched their hands out toward Jerusalem as Hinn began to pray. Hinn prayed vigorously for Israel's continued success, because its founding sixty years ago had unleashed a prophetic and miraculous season. God blessed Israel as his chosen nation and would continue to bless American so long it supported Israel. "Israel needs you now more than

\footnotetext{
105 Ephesians 5:27 (KJV).

106 See "Rice: Israel must divide Jerusalem," Israel Today, October 15, 2007, http: / / ww w.israeltoday.co.il/default.aspx?tabid=178\&nid=14294 (accessed January 20, 2010), for a proIsraeli reading of Benny Hinn's concern.
} 
ever!" he cried. Around him, the murmur of pilgrim prayers rose until it swallowed Hinn's voice altogether. ${ }^{107}$

Some prosperity preachers refused to soft pedal the grim news. God's provision rested on a national covenant that bound America and Israel to the same fate. Drawing on God's promise to Israel that "I will bless those who bless you, and the one who curses you I will curse," these participants argued that America must bless Israel to claim its own divine wealth. ${ }^{108}$ In most respects, it followed the theological framework of Christian Zionism. ${ }^{109}$ The founding of the state of Israel signaled Jesus' imminent return and — though the details remained debatable-Israel's history determined the course of the end of time. Two Pentecostal forms of Christian Zionism prevailed: apocalyptic and dispensational. Benny Hinn represented the former. He interpreted Israel's history in light of apocalyptic prophecies, but did not situate the daily news in a rigid dispensational framework. The famous Christian Zionists John Hagee and Rod Parsley took up the latter position, seeing history as divided into discrete epochs (dispensations) that dictated God's plans for human salvation. In this last epoch, Israel acted as the staging ground for the final battle of Armageddon and Jesus' return. Benny Hinn's tour split the difference between the two approaches and included sidebars for End Times tourism. We stopped at the Mount of Olives to consider prayerfully that Jesus would descend from heaven to this spot. We climbed the heights to survey the valley of Jezreel and Megiddo, where the final bloody battle will take place. Of my eighty-person tour, only Trudy, a retired schoolteacher from Wisconsin, picked through

\footnotetext{
107 Taping of This Is Your Day!. Benny Hinn's Holy Land Tour, Israel, September 12, 2008.

108 Genesis 12:3 (NIV). See Amy Frykolm, "Calculated Blessing: A Visit to John Hagee's Church" Christian Century 125, no. 20 (October 7, 2008): 35-37.

${ }^{109}$ Christian Zionism broadly referred to those who supported the modern state of Israel. A subset of Christian Zionists identified modern Israel with the biblical nation of Israel and interpreted its history according to apocalyptic biblical prophecy or classic Dispensationalism. See Tony Richie, "Dealing with the Dilemma of Christian Zionism," http: / / ww w.christianzionism.org/Article/RichieT02.pdf (accessed January 28, 2010).
} 
the apocalyptic details with relish. A frequent visitor to the Holy Land, Trudy rattled off the characteristics of the Antichrist and the battle itself before our bus-mates stopped her with skeptical questions. The rest took pictures of the panorama and shuffled down the dusty hill to the waiting buses. ${ }^{110}$

John Hagee served as the pastor of the 10,000-member Cornerstone Church in San Antonio, the nation's sixteenth-largest prosperity church and one of the leading centers of Christian Zionism. He popularized a dual commitment to the prosperity gospel and a dispensational view. In Financial Armageddon, for example, Hagee detailed the apocalyptic significance of the 2009 economic meltdown and a Faith-filled path around its obstacles. ${ }^{111}$ He preferred Jewish prayer shawls "designed by God" to regular prayer clothes, touting their special "power to energize your prayer life." ${ }^{112}$ Israel's future determined the fate of American success, as he outlined in From Daniel to Doomsday (2000), Attack on America (2001), The Battle for Jerusalem (2003), Jerusalem Countdown (2006), and In Defense of Israel (2007). ${ }^{113}$ Christians United for Israel, which Hagee founded and Parsley led, hosted yearly Washington rallies where several thousand participants and a star-studded roster of politicians and preachers vented Israel's concerns. With its advisory board comprised almost entirely by the Faith movement's top brass, the organization opposed the two-state solution to Israel's political woes by sending millions of dollars to settle new immigrants there. ${ }^{114}$ Pat Robertson famously

\footnotetext{
${ }^{110}$ Interview. Benny Hinn's Holy Land Tour, Israel, September 12, 2008.

111 John Hagee, Financial Armageddon: We are in a Battle for our Very Survival (Lake Mary, FL: FrontLine, 2008).

${ }^{112}$ Frykholm, "Calculated Blessing," 35-37.

113 John Hagee, From Daniel to Doomsday (Nashville: Thomas Nelson, 2000); John Hagee, Attack on America (Nashville: Thomas Nelson, 2001); John Hagee, The Battle for Jerusalem (Nashville: Thomas Nelson, 2003); John Hagee, Jerusalem Countdown (Lake Mary, FL: FrontLine, 2006); John Hagee, In Defense of Israel (Lake Mary, FL: FrontLine, 2007).

${ }^{114}$ Its board and directors included CBN network executives, Rhema and ORU administrators, and prosperity leaders Billye Brim (Billye Brim Ministries, Missouri), Stephen Strang (founder of Charisma magazine), Keith Butler (Word of Faith International Christian Center, Detroit), Mac and Lynne Hammond (Living Word Christian Center, Minneapolis) alongside famous fundamentalists like Jerry Falwell's son Jonathan Falwell (Thomas Road Baptist Church). Christians United for Israel. http:/ / www.cufi.org (accessed January 20,
} 
declared Yitzhak Rabin cursed for dividing Israel. ${ }^{115}$ Though the number of Faith congregations fervently supporting Zionism remained small, some of the prosperity gospel's beloved pastors applied the logic of Faith to further this international concern. God tethered believers and nations to lasting covenants.

The prosperity gospel told the Christian narrative as if it were an upward sweep toward ultimate and assured victory. Social, cultural, institutional, or individual barriers crumbled before believers to make way for personal and collective breakthroughs. The Grammy-winning Clark Sisters encapsulated the Faith movement's triumphant spirit when they sang:

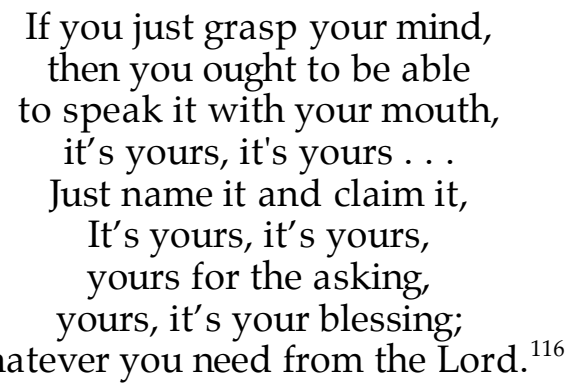

From individual victory to a blessed America, the movement reasoned that the spiritual universe operated according to fixed principles that true believers could see, plot and track. Anything hidden appeared as the far side of the moon-only temporarily occluded and momentarily darkened from human eyes. Believers would have concurred with the $18^{\text {th }}$-century writer, John Toland's title, Christianity Not Mysterious. Their gospel was supernatural to be sure, but not mysterious. Faith-filled principles guided believers through the minefield of life's obstacles toward greater and greater heights.

2010). For more on their opposition to the two-state solution see John J. Mearsheimer, The Israel Lobby and U.S. Foreign Policy (New York: Farrar, Straus and Giroux, 2007), 132-139.

${ }_{115}$ Pat Robertson, http:/ / patrobertson.com/askpat/bringiton021302.asp (accessed February 2, 2010).

116 The Clark Sisters, "Name It, Claim It," Sincerely, New Birth Records, 1982. 


\section{Conclusion: An American Gospel?}

Americans, for the most part, saw the sunny side of life. When television psychologist Dr. Phil featured a jilted wife and her book My Husband's Affair Became the Best Thing That Ever Happened to Me, audiences nodded knowingly. ${ }^{1}$ A positive outlook transformed personal slumps or tragedies into tests of character and opportunities for growth. Positive by reputation and self-image, Americans preferred to look for the silver lining. As Barbara Ehrenreich argued in Bright-Sided, American society cultivated consummate positive thinkers. They learned not simply to anticipate the best, but they relied on their upbeat expectations to change their circumstances. ${ }^{2}$ Despite being ranked $150^{\text {th }}$ in happiness among the world's nations, the United States valued preachers, prophets, and authors who taught the masses how to accent the upbeat. Beginning in the 1980s, "life-coaches" invaded corporate culture as companies hired speakers to bring "winning" attitudes in America's boardrooms. ${ }^{3}$ Corporations considered the benefits of employees' spirituality as an untapped resource. ${ }^{4}$ Psychologists devoted to the new "science of happiness" published their findings in journals like the Journal of Happiness Studies, while books such as Harvard scholar Tal Ben-Shahar's Happier and American Psychological Association President Martin Seligman's Learned Optimism and Authentic Happiness brought positive psychology to the mass market. The nation soared so high on good feelings, worried Karen Cerulo in Never Saw It Coming, that it proved to

\footnotetext{
${ }^{1}$ Anne Bercht, My Husband's Affair Became the Best Thing That Ever Happened to Me (Victoria, BC: Trafford, 2004).

${ }^{2}$ Barbara Ehrenreich, Bright-Sided: How the Relentless Promotion of Positive Thinking Has Undermined America (New York: Metropolitan Books, 2009), 1-13.

${ }^{3}$ Ehrenreich, Bright-Sided, 45-73.

${ }^{4}$ Michael Budde and Robert Brimlow, Christianity Incorporated: How Big Business Is Buying the Church (Grand Rapids: Brazos Press, 2002), 27-54.
} 
be unable to anticipate and prevent worst-case scenarios. "We should always walk with smiles on our faces, our heads held high, our shoulders squared, believing God," summarized the young Jimmy Swaggart. ${ }^{6}$ American optimism reigned as a full-fledged cultural phenomenon.

Over the last century, bright-sided faith mixed with American conceptions of the self. Numerous contemporary evangelical pastors and public speakers saw the virtue of blending the principles of positive thinking with Protestantism. Bruce Wilkinson's New York Times bestseller The Prayer of Jabez begged God for spiritual and material increase through an Old Testament prayer. His follow-up, The Dream Giver, concurred with numerous Christian authors that business acumen and Christian virtue were synonymous. ${ }^{7}$ Laurie Beth Jones, author of Jesus, CEO and Jesus, Inc. described a boardroom savior:

He didn't work for money He had impeccable market timing.

He did sweat the small stuff.

He was not a perfectionist.

He finished what he started. He knew a business plan wouldn't save him.

He was . . a spiritreneur. ${ }^{8}$

Mediocrity acquired the stigma of sin, as authors fretted about the wastefulness of lives not fully lived. "Not long ago and not far away, a Nobody named Ordinary lived in the Land of Familiar," wrote Wilkinson of the everyman. In 2007, Rhonda Byrne's breakaway hit, The Secret, became the latest New Thought-inspired articulation of the

\footnotetext{
${ }^{5}$ Karen Cerulo, Never Saw It Coming: Cultural Challenges to Envisioning the Worst (Chicago: Chicago University Press, 2006).

${ }^{6}$ Jimmy Swaggart, The Confession Principle and the Course of Nature (Baton Rouge, LA: Jimmy Swaggart Ministries, 1981), 23.

${ }^{7}$ Bruce Wilkinson, The Prayer of Jabez: Breaking Through to the Blessed Life (Portland, OR: Multnomah, 2000); Bruce Wilkinson, The Dream Giver: Following Your God-Given Destiny (Portland, OR: Multnomah, 2003).

${ }^{8}$ Laurie Beth Jones, Jesus Inc.: The Visionary Path, Promotional book insert, The Crown Public Group, 2001.
} 
idealized American self. ${ }^{9}$ Endorsed by a host of successful inventors, authors, and metaphysical leaders, the book encouraged people to direct their thoughts toward achieving their desires. Fans like Oprah Winfrey, along with the ever-increasing ranks of those claiming to be "spiritual but not religious," found that The Secret ritualized two American sentiments: people rise to the level of their own ambition; and there's no such thing as luck. ${ }^{10}$

Twentieth-century metaphysical gospels in America made the mind a spiritual playground. Common sense realism, the bread and butter of American evangelicalism, yielded to religious knowledge that was elusive and, at times, esoteric. ${ }^{11}$ Truth was ferreted out, not apparent, as it emerged from the mind's hidden recesses. American audiences eagerly sought to apply this secret knowledge to their advantage. Louise Hay's bestseller You Can Heal Your Life (1984) and Deepak Chopra's The Seven Spiritual Laws of Success (1994) stood out. Indeed, its emphasis on practice was irrepressible. Truths were techniques, waiting to be applied. Whether through hypnotism, the use of placebos, or the power of suggestion, positive thinkers cultivated religious practices and techniques to subdue, focus, or activate the mind's hidden powers. It opened the door for popular religion and the mainstream alike to construct an image of the individual as autonomous, and only as powerful as its mind.

The prosperity gospel clearly resonated with a set of national characteristics deeply embedded in the American imagination. These traits formed the basis of a national self-perception as well as fuel for religious inspiration. ${ }^{12}$ The historian William

\footnotetext{
${ }^{9}$ Rhonda Byrne, The Secret (New York: Atria Books, 2006).

${ }^{10}$ Macro R. Della Cava, "Secret history of 'The Secret,"” USA Today, March 29, 2007.

11 See, for example, Frederick Price's argument that non-Christians cannot understand the Bible. "It's a coded book, with a coded message ... the Bible is not for everyone. It's only for God's people. And you have to be connected God to have the spiritual insight to be able to understand what you are reading." See Frederick Price, Race, Religion \& Racism (Los Angeles: Faith One Publications, 1999), 40.

${ }_{12}$ William R. Hutchison, Religious Pluralism in America: The Contentious History of a Founding Ideal (New Haven, CT: Yale University Press, 2003), 59-83.
} 
Hutchison argued that American religious constants included religious activism; millennial optimism that "featured Americans as a chosen people;" moralism grounded in a sense of duty to save others; and last, individualism and the rhetoric of choice (with its accompanying responsibility). Looking back to the early Puritans, many described "American" characteristics as frugality, sobriety, punctuality, reliability, and initiative that formed the basis for the Protestant work ethic. ${ }^{13}$ At other times, Americans valued risk and daring, an aggressive edge that tamed the frontier or caused the hard business world to yield. Taken whole, American identity rested on a high anthropology. "Purveyors of democracy and freedom for all, leaders of the world's first and most successful revolution, Americans thought well of themselves," observed Catherine Albanese, "and the message of inner divinity and outer power supported their self-conceptions." ${ }^{14}$ The Faith movement's culture of god-men and conquerors rang true to a culture ensconced by the mythology of righteous individuals bending circumstances to their American dream.

\footnotetext{
${ }^{13}$ The enduring relationship between religious and economic capital often brought scholars back to the first moments of European settlement in New England. Many variations of this thesis developed, but the story goes that Max Weber, the famed German sociologist, attributed the auspicious beginnings of an individualistic capitalism to the Puritan understanding of predestination. The Puritan, torn over the undecided fate of his soul, sought evidence of his eternal fate-salvation or damnation-in the fruits of his labor. By accruing wealth through virtuous labor, work and its tangible results offered a measure of validation and assurance that the Puritan's calling was toward heaven. As historian Catherine Albanese observed, it was justification by faith, ironically, with an ethic of works. Puritan labor tested their mettle and purified their char acter, developing, among other virtues, constancy, frugality, and, in some readings, business savvy. As debates continued over a precise reading of Weber's complex thesis, a popularized version emerged that became an important aspect of Americans' self-understanding. The Protestant Ethic and the Spirit of Capitalism symbolized American values-hard work, determination, individualism-that yielded abundance and built the nation. In truth, Faith believers had little in common with Weber's Puritans. While they too sought evidence of God's favor, their salvation and triumphant victory was assured. If anything, the Faith movement represented an inversion of the Puritan understanding of social covenant. The Puritans believed that every nation lived in a covenantal relationship with God, meaning that the people would obey God's laws and God would reward them appropriately. John Winthrop, Massachusetts governor and early Puritan leader, set forth the ideals for this godly kingdom. God had chosen them, like Israel, to be a model "city on a hill," a collective example of God's presence that would shame England and glorify God. Ideally, individual desires were to be submerged into the good of the whole, as their communal spirituality meant more than an individual show of faith. See Roy Anker, Self-Help and Popular Religion in Modern American Culture: An Interpretive Guide (Westport, CT: Greenwood Press, 1999), 11-104; Catherine Albanese, America: Religion and Religions (Belmont, CA: Wadsworth, 1992), 89; Edmund Morgan, The Puritan Dilemma (New York: Longman, 1999). For a rguments connecting prosperity theology and Weber, see Rachel McCleary, http: / / blogs.ssrc.org/tif / 2009/12 / 23 / christianity-and-the-crash (accessed February 3, 2010); Vinson Synan, "Word of Faith movement has deep roots in American History," http: / / www.believersstandunited.com/word of faith movement.html (accessed January 14, 2010).

${ }^{14}$ Catherine Albanese, A Republic of Mind and Spirit (New Haven, CT: Yale University Press, 2007), 436.
} 
Yet the Faith movement did not simply give Americans a gospel worthy of a nation of self-made men. It affirmed the basic economic structures on which individual enterprise stood. Caretakers of any gospel of success trusted the "innate moral equilibrium of the marketplace" to mete out rewards and punishment in fortune or failure. ${ }^{15}$ The virtuous found greater compensation while the greedy eventually stumbled. It was a theology of excess that separated the faith-filled few from the poverty of the masses. It effectively disengaged spiritual purity from cultural separation, allowing adherents to participate fully in the world as is. Effectively mythologized in Horatio Alger's dime novels of "rags to riches," the prosperity gospel retold the inevitable triumph of character over an unruly free-market economy. That prosperity celebrity Frederick Price won the 1998 Horatio Alger award for "remarkable achievements accomplished through honesty, hard work, self-reliance, and perseverance over adversity" completed the tale. ${ }^{16}$ The prosperity gospel suited the breathless ambition of a nation of multitaskers and entrepreneurs.

Further, the Faith movement perpetually demonstrated the practical effects of their brand of optimism. Members cited the benefits of its emotional resources such as a sense of self-worth and an escape from personal pain. ${ }^{17}$ Beyond their emotion transformation, believers often saw the prosperity gospel at work. Faith churches presented a stronghold of social services and church resources that gave members a competitive advantage: social connections, educational facilities, and social assistance during times of crisis. These Faith churches, as self-supporting entities, relied on the

\footnotetext{
${ }_{15}$ Anker, Self-Help and Popular Religion in Early American Culture, 14.

${ }^{16}$ Horatio Alger Award. http:/ / www.horatioalger.com/aboutus.cfm (accessed February 3, 2010). So ingrained were these success tales that anything to the contrary caused Americans pause. Malcolm Gladwell's splashy book Outliers: The Story of Success made national news for his analysis of these rags to riches stories as mythological, by dissecting biographies for the communal, social, economic and circumstantial causes of Americans who have had unusual success. Success, he argued, emerged from a steady accumulation of advantages.

${ }^{17}$ Interviews with VFC members. See also Milmon Harrison, Righteous Riches: The Word of Faith Movement in Contemporary African American Culture (New York: Oxford University Press, 2005), 51-54.
} 
engine of a highly active lay leadership. The numerous tasks assigned to laypeopletasks that made a large church hum along—developed skills (organization, budgeting, leadership) that translated well into entrepreneurial virtues. ${ }^{18}$ Further, the prosperity gospel's high moral code inevitably kept more money in believers' pockets by prohibiting alcohol, nicotine, drugs, and promiscuous behavior. The historian and missionary Donald McGavran, author of Understanding Church Growth (1970), dubbed it "redemption and lift." ${ }^{19}$ Faith believers created many of the conditions of their own well-being.

Scholars often consider the prosperity gospel a "poor people's movement," an expression of believers' longing for (and distance from) socioeconomic stability. ${ }^{20}$ "The prosperity gospel probably originated among the poorer elements of the evangelical community in America," stated the famous theorist Peter Berger. ${ }^{21}$ In truth, scholars have not yet measured the income levels of American prosperity believers. Challenges abound. Its scattered congregations were hard to find, and often just as difficult to study. The movement that prided itself on the financial well-being of its constituents resisted disclosing pastors' salaries, church budgets, and its members' income.

Contrary to Berger and others, the evidence leaves numerous clues that American prosperity believers enjoyed a comfortable living. In the 1950s, the prosperity gospel took shape among post-World War II Pentecostals, whose modest wealth made them neither paupers nor princes. The charismatic movement, as we have seen, introduced even greater middle-class audiences. By the Faith movement's widespread

\footnotetext{
18 As the sociologists Donald E. Miller and Tetsuano Yamamori demonstrated of Pentecostal prosperity churches worldwide, the greatest beneficiaries of these churches' outreach may be the churchgoers themselves. Their discussion of the Pentecostalism and social transformation addresses the social benefits of the Pentecostal experience. Donald E. Miller and Tetsuano Yamamori, Global Pentecostalism: The New Face of Christian Social Engagement (Berkeley: University of California Press, 2007), 31-34.

${ }_{19}$ Donald McGavran, Understanding Church Growth (Grand Rapids: Eerdmans, 1990), 209-237.

${ }^{20}$ Harrison, Righteous Riches, 148-152;

${ }^{21}$ Peter Berger, http:/ / blogs.ssrc.org/tif / 2009/12/23/ christianity-and-the-crash (accessed February 3, 2010).
} 
acceptance in the 1970s, the affluence of many prosperity adherents had become plain fact. A few sundry examples illustrated their newfound status. In 1985, an analysis of 23 top-rated religious programs found that prosperity televangelists catered to the upwardly mobile and middle class, rather than the working class (with the exception of blue-collar favorite Rex Humbard). ${ }^{22}$ Pat Robertson's The 700 Club talk show, for example, earned strong ratings from educated, middle-class, and Midwestern viewers, making him the prophet of Middle America. ${ }^{23}$ Its strong presence among America's largest churches over the next three decades further reinforced the gospel's middleincome status. Studies demonstrated that though megachurch attendees drew from a variety of economic groups-from those grazing the poverty line to the upper class-the largest pool were well-educated in professional vocations. ${ }^{24}$ Prosperity did not hover out of reach as the target of inspiration: many people embraced the Faith message as a lived reality.

On one level, the appeal of prosperity theology was obvious. "I tried poverty," quipped Oral Roberts, "and I didn't like it." ${ }^{25}$ The Faith movement sold a compelling bill of goods: God, wealth, and a healthy body to enjoy it. At a fundamental level, it cultivated desire and promised fulfillment. Yet its appeal lay not simply in desire. From infomercials to window-shopping, American consumer culture built an acquisitive empire on the seduction and misdirection of desire. The prosperity gospel articulated a language of aspiration that spoke of materialism and transcendence in a single breath. It ascribed spiritual meaning to everyday needs. A letter written to Evangelist R. G.

\footnotetext{
${ }^{22}$ Sari Thomas, “The Route to Redemption: Religion and Social Class," Journal of Communication 35 (1985), 111-122.

${ }_{23}$ Stewart Mark Hoover, The 700 Club as Religion and as Television: A Study of Reasons and Effects, (Dissertation from University of Pennsylvania, 1985), 36.

${ }^{24}$ Scott Thumma and Dave Travis, Beyond Megachurch Myths (San Francisco: Jossey-Bass, 2007), 139. See also Harrison, Righteous Riches, 148-149, for themovement's middle-class appeal.

${ }^{25}$ Vinson Synan, "Word of Faith movement has deep roots in American History,"

http: / / www.believersstandunited.com/word_of faith movement.html (accessed January 14, 2010).
} 
Hardy made that point effectively. "I am writing to thank you for your prayer for a cooking stove," wrote Mrs. L. G. from Virginia, "God has answered this prayer!” Without specifics, she praised the Baltimore preacher for the $\$ 384.75$ cash she needed to buy a double oven stove. ${ }^{26}$ She wanted a God of everyday miracles.

The Faith movement seemed as American as apple pie. We have seen how it grew from religious traditions deeply rooted in the American context and flourished both in popular and institutional forms. Phases such as "favor," "abundant life," "positive confession," and "I'm blessed!" popped up in television sitcoms, reflecting a new style of piety that had become common fare. Prosperity messages echoed in the most unlikely places, reverberating through Mennonite, Moravian, and Lutheran houses of worship. Old foes became friends. Even denominations that fiercely opposed the teachings of Oral Roberts, T. L. Osborn and other early prosperity preachers borrowed a page from their playbook. Kregg Hood of the Church of Christ, an avowedly anticharismatic denomination, penned a tithing manual that might as easily have been written by Benny Hinn: Take God at His Word: Expect a Harvest. ${ }^{27}$ Business mogul Donald Trump, supermodel Tyra Banks, and superstar Michael Jackson called the Faith teacher Paula White their personal pastor. T. D. Jakes advised American presidents, past and present, with ease. When the legendary Coretta Scott King died, prosperity celebrity Bishop Eddie Long presided over the funeral.

However, as much as this is a story about American religion, it is inevitably an account of the gospel and globalization, the rapid compression of economic, social, political and cultural forces into a complex system of transnational interactions. As the anthropologist Simon Coleman noted in his study of the Swedish prosperity movement,

\footnotetext{
26 "Dear R.G. Hardy," Faith in Action, June 1973.

${ }^{27}$ Kregg Hood, Take God at His Word: Expect a Harvest (Hurst, TX: Sweet Publishing, 2001). Scott Billingsley pointed me to this source.
} 
The Word of Life, the transnational Faith movement cannot be confined to a single national context. Its preachers and ideas proved to be highly mobile and played with ease on a global stage. ${ }^{28}$ As congregations, audiences, and leaders in disparate locations became increasingly interactive and integrated, the prosperity gospel rapidly spread as a global phenomenon.

Christianity, as scholars were slowly discovering, had "gone South," as the Christian world slipped its northern moorings in Europe and North America and shifted toward Africa, Asia, and Latin America. ${ }^{29}$ Many of the world's most-attended congregations proclaimed the prosperity gospel. The world's largest church resided in Seoul, Korea, with a million souls. Its senior pastor, David Yonggi Cho, led the Yoido Full Gospel Church as a larger-than-life figure, renowned for his prosperity focus and testimony of his miraculous healing from tuberculosis. The Philippines' El Shaddai movement, a Catholic medley of prosperity and Roman Catholic themes, began in the early 1980s and grew to a following of roughly 9 to 11 million in three decades. ${ }^{30}$ The Singapore-based City Harvest Church gathered 27,000 weekly attenders to hear Dr. Kong Lee and his wife Ho Yeow Sun, the "singing pastor" and successful pop star. ${ }^{31}$ Australia's largest church, Sydney's Hillsong Church, claimed more than 20,000 attendees and an international Faith ministry. Led by pastors Brian and Bobbie Houston, Hillsong Church's famous worship music earned more than 50 gold and platinum sales awards to become some of the most popular Christian contemporary

\footnotetext{
${ }^{28}$ Simon Coleman, The Globalisation of Charismatic Christianity: Spreading the Gospel of Prosperity (Cambridge: Cambridge University Press, 2000).

${ }_{29}$ The term "Global South" replaces "third-world" and "developing countries" as the preferred descriptor for Africa, Central and South America, and most of Asia. For vivid accounts of this movement of Christianity away from the Global North, see Philip Jenkins, The Next Christendom: The Coming of Global Christianity, (New York: Oxford University Press, 2007); Lamin Sanneh, Whose Religion is Christianity? The Gospel Beyond the West, (Grand Rapids: Eerdmans, 1993).

${ }_{30}$ Katharine Wiegele, Investing in Miracles: El Shaddai and the Transformation of Popular Catholicism in the Philippines (Honolulu: University of Hawaii Press, 2005), 4.

${ }^{31}$ Kristina Göransson, The Binding Tie: Chinese Intergenerational Relations in Modern Singapore

(Honolulu: University of Hawaii Press, 2009), 67.
} 
songs in the world. Brazil's Universal Church of the Kingdom of God grew to one of the world's largest prosperity denominations, with 2,000 congregations across its native land alone. Nigeria's Winners Chapel and Faith Tabernacle seated more than 50,000 apiece for prosperity teaching in the nation's capital.

The prosperity gospel proved to be readily exportable. The degree to which these international prosperity churches relied on American Faith teaching has not yet been determined. ${ }^{32}$ Yet we can see clearly that preachers and ideas bounced back and forth in this global spiritual market. When Brother Mike Velarde searched for a name for his independent Catholic prosperity gospel, he found it in the title of Kenneth Hagin booklet, El Shaddai: The God Who is More Than Enough. ${ }^{33}$ Yet few American believers would have recognized this Faith message as their own when Brother Mike rallied his followers to depose or elect various Filipino officials. The prosperity gospel, like all indigenized faith, transformed as it traveled.

So too, the American gospel changed in light of its global dimensions, and even Americans found that they relied on and imported its many international incarnations. As non-European Christianity swelled, the American pool of Christian immigrants rose with it. Newcomers from the Global South, particularly believers drawn from Central America, Latin America, and Africa, filled American pews and coffers. Sociologist Steven Warner reported that two thirds of America's newcomers were Christians. ${ }^{34}$ The American prosperity gospel enjoyed the benefits. The Korean pastor David Cho became the world authority on church growth, touring American churches from the late 1970s onward as a trusted advisor. The Yoido Full Gospel Church's 600 missionaries canvassed the globe planting churches in over 60 countries, including the United

\footnotetext{
32 Steve Brouwer, Paul Gifford, and Susan Rose, Exporting the American Gospel: Global Christian Fundamentalism (New York: Routledge, 1996), 1-46.

${ }^{33}$ Kenneth Hagin, El Shaddai: The God Who Is More Than Enough (Tulsa: Kenneth Hagin Ministries, 1987).

34 Stephen Warner, "Immigrants and the Faith They Bring," The Christian Century (February 10, 2004), $20-$ 23.
} 
States. ${ }^{35}$ In 1986, the Universal Church of the Kingdom of God (UCKG), a Brazilian denomination with prosperity themes, opened its doors in the United States, with 138 outreach centers scattered across 19 states. ${ }^{36}$ Myles Munroe of the Bahamas grew to be one of the most popular leaders in the American Faith movement. Armed with an honorary doctorate from Oral Roberts University and a winsome personality, audiences enjoyed his island approach to "kingdom principles." ${ }^{37}$ A Nigerian recipe for Christian prosperity proved especially popular in America. By 2010, the Redeemed Christian Church of God (RCCG), founded in 1952 by Josiah Akindayomi, founded 359 congregations across the country. ${ }^{38}$ Their aggressive strategies for church planting and enthusiastic worship enticed new immigrant groups-Asian, African, Latin American, and Caribbean in particular-at a steady rate. Their North American headquarters, a 550-acre compound in Hunt County, Texas, demonstrated their commitment to expansive American evangelism. Even the gospel from Down Under returned to win American converts. In 1999, Steve Kelly, a former associate pastor at Hillsong Church, left Australia to found the 3,000-member Wave Church in Virginia Beach, Virginia. ${ }^{39}$

Above all, the prosperity gospel transcended national boundaries with its highflying confidence. Gloria Copeland, like all Faith teachers, preached about a world in which all things were possible. When a hurricane that threatened her home, she told listeners at the 2006 Azusa Centennial that she believed that "I can do all things through Christ who strengthens me." She woke up her husband and told him of her plan. They crept down to their back porch in the darkness of the storm and they prayed Faith to the storm, declaring it unable to cross their property line. For good

\footnotetext{
${ }^{35}$ Yoido Full Gospel Church Story, http:/ / english.fgtv.com/yfgc.pdf (accessed February 5, 2010).

36 The Universal Church of the Kingdom of God, http: / / universal.org/ who-where-how / ourlocations.html, (accessed January 14, 2010).

${ }_{37}$ Myles Munroe Ministries, http:/ / www.bfmmm.com (accessed February 8, 2010).

${ }^{38}$ The Redeemed Christian Church of God, http:/ / ww w.rccg.org (accessed February 8, 2010).

${ }^{39}$ Wave Church, http:/ / w ww.wavechurch.com (accessed February 8, 2010).
} 
measure, they protected their neighbor's property as well. ${ }^{40}$ The image of two of the world's wealthiest Christians shaking their fists as the sky illustrated the audacity that characterized the new face of popular religion. A host of American preachers claimed not only to predict the rain and the harvest, but also to tell it when to pour.

${ }^{40}$ Gloria Copeland, Azusa Street Centennial General Sessions (CD), (Divide, CO: Kingdom Recordings, 2006). 


\section{Appendix}

\begin{tabular}{|c|c|c|c|c|c|}
\hline & Church & $\begin{array}{l}\text { Senior } \\
\text { Pastor }\end{array}$ & Attendance & Location & Denomination \\
\hline 1 & $\begin{array}{l}\text { Lakewood } \\
\text { Church }\end{array}$ & $\begin{array}{l}\text { Joel } \\
\text { Osteen }\end{array}$ & 43,500 & $\begin{array}{l}\text { Houston, } \\
\text { TX }\end{array}$ & NON \\
\hline 2 & $\begin{array}{l}\text { West Angeles } \\
\text { Church of God } \\
\text { in Christ }\end{array}$ & $\begin{array}{l}\text { Charles } \\
\text { Blake }\end{array}$ & 20,000 & $\begin{array}{l}\text { Los } \\
\text { Angeles, CA }\end{array}$ & COGIC \\
\hline 3 & $\begin{array}{l}\text { The Potter's } \\
\text { House }\end{array}$ & $\begin{array}{l}\text { T. D. } \\
\text { Jakes }\end{array}$ & 17,000 & Dallas, TX & NON \\
\hline 4 & $\begin{array}{l}\text { Phoenix First } \\
\text { Assembly of } \\
\text { God }\end{array}$ & $\begin{array}{l}\text { Tommy } \\
\text { Barnett }\end{array}$ & 16,000 & $\begin{array}{l}\text { Phoenix, } \\
\text { AZ }\end{array}$ & AG \\
\hline 5 & $\begin{array}{l}\text { World } \\
\text { Changers } \\
\text { Ministries }\end{array}$ & $\begin{array}{l}\text { Creflo } \\
\text { Dollar }\end{array}$ & 15,000 & $\begin{array}{l}\text { College } \\
\text { Park, GA }\end{array}$ & NON \\
\hline 6 & $\begin{array}{l}\text { New Light } \\
\text { Christian } \\
\text { Center }\end{array}$ & $\begin{array}{l}\text { I. V. } \\
\text { Hilliard }\end{array}$ & 13,500 & $\begin{array}{l}\text { Houston, } \\
\text { TX }\end{array}$ & NON \\
\hline 7 & $\begin{array}{l}\text { New Birth } \\
\text { Missionary } \\
\text { Baptist }\end{array}$ & Eddie Long & 13,000 & $\begin{array}{l}\text { Lithonia, } \\
\text { GA }\end{array}$ & BAPT \\
\hline 8 & $\begin{array}{l}\text { Gateway } \\
\text { Church }\end{array}$ & $\begin{array}{l}\text { Robert } \\
\text { Morris }\end{array}$ & 11,295 & $\begin{array}{l}\text { Southlake, } \\
\text { TX }\end{array}$ & NON \\
\hline 9 & $\begin{array}{l}\text { Church on the } \\
\text { Move }\end{array}$ & $\begin{array}{l}\text { Willie } \\
\text { George }\end{array}$ & 11,000 & Tulsa, OK & NON \\
\hline 10 & $\begin{array}{l}\text { Word of Faith } \\
\text { International } \\
\text { Christian } \\
\text { Center }\end{array}$ & $\begin{array}{l}\text { Keith } \\
\text { Butler }\end{array}$ & 11,000 & $\begin{array}{l}\text { Southfield, } \\
\text { MI }\end{array}$ & NON \\
\hline 11 & $\begin{array}{l}\text { Redemption } \\
\text { World } \\
\text { Outreach } \\
\text { Center }\end{array}$ & $\begin{array}{l}\text { Ron } \\
\text { Carpenter }\end{array}$ & 10,550 & $\begin{array}{l}\text { Greenville, } \\
\text { SC }\end{array}$ & IPHC \\
\hline 12 & $\begin{array}{l}\text { The Rock and } \\
\text { World } \\
\text { Outreach } \\
\text { Center }\end{array}$ & $\begin{array}{l}\text { Jim and } \\
\text { Deborah } \\
\text { Cobrae }\end{array}$ & 10,454 & $\begin{array}{l}\text { San } \\
\text { Bernardino, } \\
\text { CA }\end{array}$ & NON \\
\hline 13 & $\begin{array}{l}\text { Faith } \\
\text { Fellowship } \\
\text { Ministries }\end{array}$ & $\begin{array}{l}\text { David } \\
\text { Demola }\end{array}$ & 10,300 & $\begin{array}{l}\text { Sayreville, } \\
\text { NJ }\end{array}$ & NON \\
\hline 14 & $\begin{array}{l}\text { Greater St. } \\
\text { Stephen Full } \\
\text { Gospel Baptist }\end{array}$ & $\begin{array}{l}\text { Paul } \\
\text { Morton }\end{array}$ & 10,000 & $\begin{array}{l}\text { New } \\
\text { Orleans, LA }\end{array}$ & BAPT \\
\hline
\end{tabular}




\begin{tabular}{|c|c|c|c|c|c|}
\hline 15 & $\begin{array}{l}\text { Free Chapel } \\
\text { Worship } \\
\text { Center }\end{array}$ & $\begin{array}{l}\text { Jentezen } \\
\text { Franklin }\end{array}$ & 10,000 & $\begin{array}{l}\text { Gainesville, } \\
\text { GA }\end{array}$ & $\mathrm{CHC}$ \\
\hline 16 & $\begin{array}{l}\text { Cornerstone } \\
\text { Church }\end{array}$ & $\begin{array}{l}\text { John } \\
\text { Hagee }\end{array}$ & 10,000 & $\begin{array}{l}\text { San } \\
\text { Antonio, TX }\end{array}$ & NON \\
\hline 17 & $\begin{array}{l}\text { Jubilee } \\
\text { Christian } \\
\text { Center }\end{array}$ & $\begin{array}{l}\text { Dick } \\
\text { Bernal }\end{array}$ & 10,000 & $\begin{array}{l}\text { San Jose, } \\
\text { CA }\end{array}$ & NON \\
\hline 18 & City of Refuge & Noel Jones & 10,000 & $\begin{array}{l}\text { Gardena, } \\
\text { CA }\end{array}$ & PAW \\
\hline 19 & $\begin{array}{l}\text { Church on the } \\
\text { Way }\end{array}$ & $\begin{array}{l}\text { Jim Tolle } \\
\text { (formerly } \\
\text { Jack } \\
\text { Hayford) }\end{array}$ & 9,869 & $\begin{array}{l}\text { Van Nuys, } \\
\text { CA }\end{array}$ & $4 S Q$ \\
\hline 20 & $\begin{array}{l}\text { Abundant } \\
\text { Living Faith } \\
\text { Center }\end{array}$ & $\begin{array}{l}\text { Charles } \\
\text { Nieman }\end{array}$ & 9,750 & El Paso, TX & NON \\
\hline 21 & $\begin{array}{l}\text { Victory } \\
\text { Christian } \\
\text { Center }\end{array}$ & $\begin{array}{l}\text { Billy } \\
\text { Daugherty }\end{array}$ & 9,255 & Tulsa, OK & VCC \\
\hline 22 & $\begin{array}{l}\text { Detroit World } \\
\text { Outreach } \\
\text { Center }\end{array}$ & $\begin{array}{l}\text { Ben } \\
\text { Gilbert } \\
\text { (formerly } \\
\text { Jack } \\
\text { Wallace) } \\
\end{array}$ & 9,000 & Redford, MI & $A G$ \\
\hline 23 & $\begin{array}{l}\text { Mount Zion } \\
\text { Baptist } \\
\text { Church }\end{array}$ & $\begin{array}{l}\text { Joseph } \\
\text { Walker III }\end{array}$ & 9,000 & $\begin{array}{l}\text { Nashville, } \\
\text { TN }\end{array}$ & BAPT \\
\hline 24 & $\begin{array}{l}\text { Family } \\
\text { Christian } \\
\text { Center } \\
\end{array}$ & $\begin{array}{l}\text { Steve } \\
\text { Munsey }\end{array}$ & 9,000 & Munster, IN & NON \\
\hline 25 & $\begin{array}{l}\text { Living Word } \\
\text { Christian } \\
\text { Center }\end{array}$ & $\begin{array}{l}\text { Mac } \\
\text { Hammond }\end{array}$ & 8,000 & $\begin{array}{l}\text { Minneapolis } \\
\text {, MN }\end{array}$ & NON \\
\hline 26 & $\begin{array}{l}\text { Shoreline } \\
\text { Christian } \\
\text { Center }\end{array}$ & Rob Koke & 8,000 & Austin, TX & NON \\
\hline 27 & $\begin{array}{l}\text { Bethany } \\
\text { World Prayer } \\
\text { Center }\end{array}$ & $\begin{array}{l}\text { Larry } \\
\text { Stockstill }\end{array}$ & 8,000 & Baker, LA & NON \\
\hline 28 & $\begin{array}{l}\text { Victory } \\
\text { Christian } \\
\text { Center } \\
\end{array}$ & Mark Crow & 7,800 & $\begin{array}{l}\text { Oklahoma } \\
\text { City, OK }\end{array}$ & NON \\
\hline 29 & $\begin{array}{l}\text { Inspiring } \\
\text { Body of Christ } \\
\text { Church }\end{array}$ & $\begin{array}{l}\text { Rickie } \\
\text { Rush }\end{array}$ & 7,500 & Dallas, TX & NON \\
\hline
\end{tabular}




\begin{tabular}{|c|c|c|c|c|c|}
\hline 30 & $\begin{array}{l}\text { Fountain of } \\
\text { Praise }\end{array}$ & $\begin{array}{l}\text { Remus } \\
\text { Wright }\end{array}$ & 7,500 & $\begin{array}{l}\text { Houston, } \\
\text { TX }\end{array}$ & BAPT \\
\hline 31 & $\begin{array}{l}\text { Jericho City of } \\
\text { Praise }\end{array}$ & $\begin{array}{l}\text { Betty } \\
\text { Peebles }\end{array}$ & 7,500 & $\begin{array}{l}\text { Landover, } \\
\text { MD }\end{array}$ & BAPT \\
\hline 32 & $\begin{array}{l}\text { Word of Faith } \\
\text { Family } \\
\text { Worship } \\
\text { Center }\end{array}$ & $\begin{array}{l}\text { Dale } \\
\text { Bronner }\end{array}$ & 7,300 & $\begin{array}{l}\text { East Point, } \\
\text { GA }\end{array}$ & NON \\
\hline 33 & $\begin{array}{l}\text { Faithful } \\
\text { Central } \\
\text { Missionary } \\
\text { Baptist } \\
\text { Church } \\
\end{array}$ & $\begin{array}{l}\text { Kenneth } \\
\text { Ulmer }\end{array}$ & 7,250 & $\begin{array}{l}\text { Inglewood, } \\
\text { CA }\end{array}$ & BAPT \\
\hline 34 & $\begin{array}{l}\text { Jubilee } \\
\text { Christian } \\
\text { Church } \\
\end{array}$ & $\begin{array}{l}\text { Gilbert } \\
\text { Thompson }\end{array}$ & 7,000 & Boston, MA & NON \\
\hline 35 & $\begin{array}{l}\text { Victory World } \\
\text { Church }\end{array}$ & $\begin{array}{l}\text { Dennis } \\
\text { Rouse } \\
\end{array}$ & 6,530 & $\begin{array}{l}\text { Norcrosse, } \\
\text { GA }\end{array}$ & NON \\
\hline 36 & $\begin{array}{l}\text { The } \\
\text { Champions } \\
\text { Centre } \\
\end{array}$ & $\begin{array}{l}\text { Kevin and } \\
\text { Sheila } \\
\text { Gerald }\end{array}$ & 6,500 & $\begin{array}{l}\text { Tacoma, } \\
\text { WA }\end{array}$ & NON \\
\hline 37 & $\begin{array}{l}\text { The City } \\
\text { Church }\end{array}$ & $\begin{array}{l}\text { Wendell } \\
\text { and Gini } \\
\text { Smith } \\
\end{array}$ & 6,085 & $\begin{array}{l}\text { Kirkland, } \\
\text { WA }\end{array}$ & NON \\
\hline 38 & $\begin{array}{l}\text { Acts Full } \\
\text { Gospel } \\
\text { Church }\end{array}$ & $\begin{array}{l}\text { Bob } \\
\text { Jackson }\end{array}$ & 6,000 & $\begin{array}{l}\text { Oakland, } \\
\text { CA }\end{array}$ & COGIC \\
\hline 39 & $\begin{array}{l}\text { University } \\
\text { Park Baptist } \\
\text { Church }\end{array}$ & $\begin{array}{l}\text { Claude } \\
\text { Alexander, } \\
\text { Jr. }\end{array}$ & 6,000 & $\begin{array}{l}\text { Charlotte, } \\
\text { NC }\end{array}$ & BGC \\
\hline 40 & $\begin{array}{l}\text { Christian } \\
\text { Faith Center }\end{array}$ & $\begin{array}{l}\text { Casey } \\
\text { Treat }\end{array}$ & 5,909 & Seattle, WA & NON \\
\hline 41 & $\begin{array}{l}\text { Calvary } \\
\text { Assembly of } \\
\text { God }\end{array}$ & $\begin{array}{l}\text { George } \\
\text { Cope (Roy } \\
\text { Harthern) }\end{array}$ & 5,000 & Orlando, FL & AG \\
\hline 42 & $\begin{array}{l}\text { The Living } \\
\text { Word Bible } \\
\text { Church }\end{array}$ & $\begin{array}{l}\text { Thomas } \\
\text { Anderson }\end{array}$ & 5,000 & Mesa, AZ & NON \\
\hline 43 & $\begin{array}{l}\text { Crenshaw } \\
\text { Christian } \\
\text { Center } \\
\end{array}$ & $\begin{array}{l}\text { Frederick } \\
\text { Price }\end{array}$ & 5,000 & $\begin{array}{l}\text { Los } \\
\text { Angeles, CA }\end{array}$ & NON \\
\hline 44 & $\begin{array}{l}\text { World Harvest } \\
\text { Church }\end{array}$ & $\begin{array}{l}\text { Rod } \\
\text { Parsley }\end{array}$ & 5,000 & $\begin{array}{l}\text { Columbus, } \\
\mathrm{OH}\end{array}$ & NON \\
\hline 45 & $\begin{array}{l}\text { Heritage } \\
\text { Christian } \\
\text { Center } \\
\end{array}$ & $\begin{array}{l}\text { Dennis } \\
\text { Leonard }\end{array}$ & 5,000 & Denver, CO & BAPT \\
\hline 46 & $\begin{array}{l}\text { Greater Mt. } \\
\text { Calvary Holy } \\
\text { Church }\end{array}$ & $\begin{array}{l}\text { Alfred } \\
\text { Owens }\end{array}$ & 5,000 & $\begin{array}{l}\text { Washington } \\
\text {, D.C. }\end{array}$ & PENT \\
\hline
\end{tabular}




\begin{tabular}{|c|c|c|c|c|c|}
\hline 47 & $\begin{array}{l}\text { The Word } \\
\text { Church }\end{array}$ & $\begin{array}{l}\text { R. A. } \\
\text { Vernon }\end{array}$ & 5,000 & $\begin{array}{l}\text { Warrensvill } \\
\text { e Heights, } \\
\mathrm{OH}\end{array}$ & NON \\
\hline 48 & Rock Church & $\begin{array}{l}\text { Anne } \\
\text { Gimenez }\end{array}$ & 5,000 & $\begin{array}{l}\text { Virginia } \\
\text { Beach, VA }\end{array}$ & NON \\
\hline 49 & $\begin{array}{l}\text { Abundant } \\
\text { Living Family } \\
\text { Church }\end{array}$ & $\begin{array}{l}\text { Diego } \\
\text { Mesa }\end{array}$ & 5,000 & $\begin{array}{l}\text { Rancho } \\
\text { Cucamonga } \\
\text {, CA }\end{array}$ & NON \\
\hline 50 & $\begin{array}{l}\text { Christian } \\
\text { Faith Center }\end{array}$ & $\begin{array}{l}\text { Mack } \\
\text { Timberlake }\end{array}$ & 5,000 & $\begin{array}{l}\text { Creedmoor, } \\
\text { NC }\end{array}$ & NON \\
\hline 51 & $\begin{array}{l}\text { Without Walls } \\
\text { International } \\
\text { Place }\end{array}$ & $\begin{array}{l}\text { Randy } \\
\text { White }\end{array}$ & 5,000 & Tampa, FL & NON \\
\hline 52 & $\begin{array}{l}\text { Benny Hinn } \\
\text { Ministries }\end{array}$ & $\begin{array}{l}\text { Benny } \\
\text { Hinn }\end{array}$ & 5,000 & Irving, TX & NON \\
\hline 53 & Faith World & $\begin{array}{l}\text { Clint } \\
\text { Brown }\end{array}$ & 5,000 & Orlando, FL & NON \\
\hline 54 & $\begin{array}{l}\text { Evangel World } \\
\text { Prayer Center }\end{array}$ & $\begin{array}{l}\text { Bob } \\
\text { Rogers }\end{array}$ & 4,706 & $\begin{array}{l}\text { Louisville, } \\
\text { KY }\end{array}$ & AG \\
\hline 55 & $\begin{array}{l}\text { Trinity } \\
\text { Fellowship } \\
\end{array}$ & $\begin{array}{l}\text { Jimmy } \\
\text { Evans }\end{array}$ & 4,500 & $\begin{array}{l}\text { Amarillo, } \\
\text { TX }\end{array}$ & NON \\
\hline 56 & $\begin{array}{l}\text { Perfecting } \\
\text { Church }\end{array}$ & $\begin{array}{l}\text { Marvin } \\
\text { Winans }\end{array}$ & 4,500 & Detroit, MI & NON \\
\hline 57 & $\begin{array}{l}\text { Living Word } \\
\text { Christian } \\
\text { Center } \\
\end{array}$ & $\begin{array}{l}\text { William } \\
\text { Winston }\end{array}$ & 4,500 & $\begin{array}{l}\text { Forest } \\
\text { Park, IL }\end{array}$ & NON \\
\hline 58 & $\begin{array}{l}\text { Greater Grace } \\
\text { Temple }\end{array}$ & $\begin{array}{l}\text { Charles } \\
\text { Ellis }\end{array}$ & 4,500 & Detroit, MI & PAW \\
\hline 59 & $\begin{array}{l}\text { Turner Chapel } \\
\text { AME Church }\end{array}$ & $\begin{array}{l}\text { Kenneth } \\
\text { Marcus }\end{array}$ & 4,400 & $\begin{array}{l}\text { Marietta, } \\
\text { GA }\end{array}$ & AME \\
\hline 60 & $\begin{array}{l}\text { Deliverance } \\
\text { Evangelistic } \\
\text { Church } \\
\end{array}$ & $\begin{array}{l}\text { Benjamin } \\
\text { Smith }\end{array}$ & 4,000 & $\begin{array}{l}\text { Philadelphi } \\
\text { a, PA }\end{array}$ & $?$ \\
\hline 61 & $\begin{array}{l}\text { Saint Peters } \\
\text { World } \\
\text { Outreach } \\
\text { Center }\end{array}$ & $\begin{array}{l}\text { James } \\
\text { Hash }\end{array}$ & 4,000 & $\begin{array}{l}\text { Winston- } \\
\text { Salem, NC }\end{array}$ & NON \\
\hline 62 & $\begin{array}{l}\text { Higher } \\
\text { Dimension } \\
\text { Church } \\
\end{array}$ & $\begin{array}{l}\text { Terrance } \\
\text { Johnson }\end{array}$ & 3,700 & $\begin{array}{l}\text { Houston, } \\
\text { TX }\end{array}$ & NON \\
\hline 63 & $\begin{array}{l}\text { Celebration } \\
\text { Covenant } \\
\text { Church } \\
\end{array}$ & Keith Craft & 3,500 & Frisco, TX & NON \\
\hline 64 & $\begin{array}{l}\text { Orchard Road } \\
\text { Christian } \\
\text { Center } \\
\end{array}$ & $\begin{array}{l}\text { Wallace } \\
\text { Hickey }\end{array}$ & 3,500 & Denver, CO & NON \\
\hline 65 & $\begin{array}{l}\text { Crystal } \\
\text { Cathedral }\end{array}$ & $\begin{array}{l}\text { Robert } \\
\text { Schuller }\end{array}$ & 3,000 & $\begin{array}{l}\text { Garden } \\
\text { Grove, CA }\end{array}$ & RCA \\
\hline
\end{tabular}




\begin{tabular}{|c|c|c|c|c|c|}
\hline 66 & $\begin{array}{l}\text { New } \\
\text { Beginnings } \\
\text { Christian } \\
\text { Center } \\
\end{array}$ & Larry Huch & 3,000 & Dallas, TX & NON \\
\hline 67 & $\begin{array}{l}\text { Abundant Life } \\
\text { Christian } \\
\text { Center }\end{array}$ & $\begin{array}{l}\text { Walter } \\
\text { Hallam }\end{array}$ & 3,000 & $\begin{array}{l}\text { La Marque, } \\
\text { TX }\end{array}$ & NON \\
\hline 68 & $\begin{array}{l}\text { Spirit of Faith } \\
\text { Christian } \\
\text { Center } \\
\end{array}$ & $\begin{array}{l}\text { Mike } \\
\text { Freemen }\end{array}$ & 3,000 & $\begin{array}{l}\text { Temple } \\
\text { Hills, MD }\end{array}$ & NON \\
\hline 69 & $\begin{array}{l}\text { Abundant Life } \\
\text { Christian } \\
\text { Centre } \\
\end{array}$ & $\begin{array}{l}\text { Rick } \\
\text { Thomas }\end{array}$ & 3,000 & Margate, FL & NON \\
\hline 70 & Wave Church & $\begin{array}{l}\text { Steve } \\
\text { Kelly }\end{array}$ & 3,000 & $\begin{array}{l}\text { Virginia } \\
\text { Beach, VA }\end{array}$ & NON \\
\hline 71 & $\begin{array}{l}\text { Kingdom } \\
\text { Church }\end{array}$ & $\begin{array}{l}\text { Dharius } \\
\text { Daniels }\end{array}$ & 3,000 & Trenton, NJ & NON \\
\hline 72 & $\begin{array}{l}\text { Victory } \\
\text { Worship } \\
\text { Center } \\
\end{array}$ & $\begin{array}{l}\text { Zane } \\
\text { Anderson }\end{array}$ & 3,000 & Tucson, AZ & AG \\
\hline 73 & $\begin{array}{l}\text { City Bible } \\
\text { Church }\end{array}$ & $\begin{array}{l}\text { Frank } \\
\text { Damazio } \\
\text { (Dick } \\
\text { Iverson) } \\
\end{array}$ & 2,900 & $\begin{array}{l}\text { Portland, } \\
\text { OR }\end{array}$ & NON \\
\hline 74 & $\begin{array}{l}\text { First } \\
\text { Cathedral }\end{array}$ & $\begin{array}{l}\text { Leroy } \\
\text { Bailey, Jr. }\end{array}$ & 2,800 & $\begin{array}{l}\text { Bloomfield, } \\
\text { CT }\end{array}$ & NBC-ABC \\
\hline 75 & $\begin{array}{l}\text { Faith Christian } \\
\text { Center }\end{array}$ & $\begin{array}{l}\text { Keth } \\
\text { Butler } \\
\text { II/Joel } \\
\text { Gregory }\end{array}$ & 2,700 & $\begin{array}{l}\text { Smyrna, } \\
\text { GA }\end{array}$ & NON \\
\hline 76 & $\begin{array}{l}\text { Destiny } \\
\text { Christian } \\
\text { Center }\end{array}$ & Lee Stokes & 2,500 & $\begin{array}{l}\text { Greensboro } \\
\text {, NC }\end{array}$ & NON \\
\hline 77 & $\begin{array}{l}\text { Evangel } \\
\text { Cathedral }\end{array}$ & Don Mears & 2,500 & $\begin{array}{l}\text { Upper } \\
\text { Marlboro, } \\
\text { MD }\end{array}$ & NON \\
\hline 78 & $\begin{array}{l}\text { Impacting } \\
\text { Your World } \\
\text { Christian } \\
\text { Center }\end{array}$ & $\begin{array}{l}\text { Ray and } \\
\text { Tracey } \\
\text { Barnard }\end{array}$ & 2,500 & $\begin{array}{l}\text { Philadelphi } \\
\text { a, PA }\end{array}$ & VFC \\
\hline 79 & $\begin{array}{l}\text { Kingdom Life } \\
\text { Christian } \\
\text { Church }\end{array}$ & $\begin{array}{l}\text { Jay } \\
\text { Ramirez }\end{array}$ & 2,100 & Milford, CT & NON \\
\hline 80 & $\begin{array}{l}\text { Rhema Bible } \\
\text { Church }\end{array}$ & $\begin{array}{l}\text { Kenneth } \\
\text { Hagin }\end{array}$ & 2,000 & Tulsa, OK & NON \\
\hline 81 & $\begin{array}{l}\text { Oasis } \\
\text { Christian } \\
\text { Center }\end{array}$ & $\begin{array}{l}\text { Phillip and } \\
\text { Holly } \\
\text { Wagner }\end{array}$ & 2,000 & $\begin{array}{l}\text { Los } \\
\text { Angeles, CA }\end{array}$ & NON \\
\hline
\end{tabular}




\begin{tabular}{|c|c|c|c|c|c|}
\hline 82 & $\begin{array}{l}\text { Ray of Hope } \\
\text { Christian } \\
\text { Church }\end{array}$ & $\begin{array}{l}\text { Cynthia } \\
\text { Hale }\end{array}$ & 2,000 & $\begin{array}{l}\text { Decatur, } \\
\text { GA }\end{array}$ & DOC \\
\hline 83 & $\begin{array}{l}\text { Winners } \\
\text { Church }\end{array}$ & $\begin{array}{l}\text { Fred } \\
\text { Shipman }\end{array}$ & 2,000 & $\begin{array}{l}\text { West Palm } \\
\text { Beach, FL }\end{array}$ & NON \\
\hline 84 & $\begin{array}{l}\text { Empowerment } \\
\text { Temple AME } \\
\text { Church }\end{array}$ & $\begin{array}{l}\text { Jamal- } \\
\text { Harrison- } \\
\text { Bryant } \\
\end{array}$ & 2,000 & $\begin{array}{l}\text { Baltimore, } \\
\text { MD }\end{array}$ & AME \\
\hline 85 & $\begin{array}{l}\text { Overcoming } \\
\text { Faith } \\
\text { Christian } \\
\text { Center } \\
\end{array}$ & $\begin{array}{l}\text { Gene and } \\
\text { Sue } \\
\text { Lingerfeld }\end{array}$ & 2,000 & $\begin{array}{l}\text { Arlington, } \\
\text { TX }\end{array}$ & NON \\
\hline 86 & $\begin{array}{l}\text { Family Praise } \\
\text { Center }\end{array}$ & $\begin{array}{l}\text { Rick } \\
\text { Hawkins }\end{array}$ & 2,000 & $\begin{array}{l}\text { San } \\
\text { Antonio, TX }\end{array}$ & NON \\
\hline
\end{tabular}

DENGMINATION KEY

\author{
ABC - American Baptist \\ ABC/NBC NBC/ABC - Dually aligned \\ American Baptist and National Baptist \\ AG - Assemblies of God \\ AME - African Methodist Episcopal \\ BGC - Baptist General Conference \\ BAPT - Baptist (unspecified) \\ COGIC - Church of God in Christ \\ CHC - Congregational Holiness Church \\ DOC - Disciples of Christ \\ 4SQ - Four Square \\ HOLINESS - Holiness (unspecified)
}

IPHC - International Pentecostal Holiness Church

NBC - National Baptist Convention

NON- Nondenominational

PAW - Pentecostal Assemblies of the World

PCA - Presbyterian Church of America

PENT - Pentecostal (unspecified)

RCA - Reformed Church in America

VCC - Victory Christian Center 


\section{Bibliography}

\section{Archives and Manuscript Collections}

Dixon Pentecostal Research Center

\section{Periodicals}

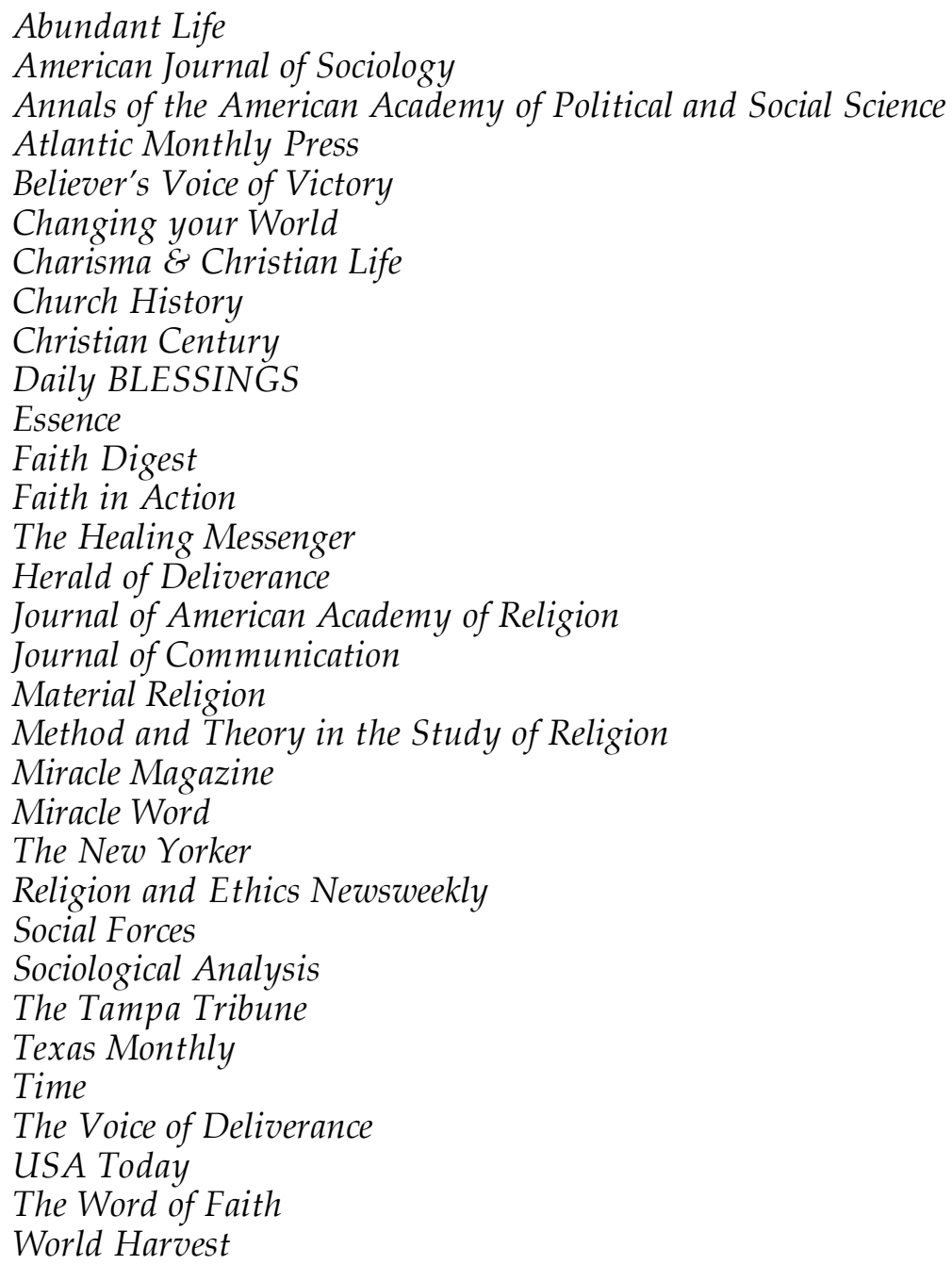

\section{Primary Sources}

Allen, A. A. God's Guarantee to Bless and Prosper You Financially. Miracle Valley, AZ: A. A. Allen Publications, 1969.

. Your Christian Dollar. Miracle Valley, AZ: A. A. Allen Publications, 1958. 
—. The Secret to Scriptural Financial Success. Miracle Valley, AZ: A. A. Allen Publications, 1953.

Avanzini, John. It's Not Working, Brother John: 25 Things That Close the Windows of Heaven. Tulsa: Harrison House, 1992.

- The Wealth of the World: The Proven Wealth Transfer System. Tulsa: Harrison House, 1989.

Bakker, Tammi Faye. We're Blest, PTL Records, 1979.

Basham, Don. Deliver Us from Evil. Washington Depot, CT: Chosen Books, 1972.

—. Lead Us Not Into Temptation. Old Tappan, NJ: Chosen Books, 1986.

Bercht, Anne. My Husband's Affair Became the Best Thing That Ever Happened to Me. Victoria, BC.: Trafford, 2004.

Bishop, Markus. Our Covenant of Prosperity: Crossing the Threshold of Supernatural Abundance. Tulsa: Harrison House, 1997.

Bosworth, F. F. Christ the Healer. Old Tappan, New Jersey: Fleming H. Revell Company, 1973.

Brazee, Mark. 365 Days of Healing. Tulsa: Harrison House, 2006.

Bynum, Juanita. “I Don’t Mind Waiting.” Flow Records, 2006.

—. Matters of the Heart. Lake Mary, FL.: Charisma House, 2002.

Byrne, Rhonda. The Secret. New York: Atria Books, 2006.

Capps, Charles. The Tongue: A Creative Force. England, AR: Capps Publishing, 1976.

Capps, Charles and Annette Capps. Angels. Tulsa: Harrison House, 1984.

Cerullo, Morris. A Guide to Total Health and Prosperity. San Diego: World Evangelism Inc., 1977.

Chrystyn, Julie. The Secret to Life Transformation: How to Claim Your Destiny Now! Beverley Hills: Dove Books, 2009.

Clark Sheard, Karen. "Blessed and Highly Favored." One Last Time. EMI Gospel, 2007.

The Clark Sisters, “Name It, Claim It,” Sincerely, New Birth Records, 1982.

Conwell, Russell H. Acres of Diamonds. Philadelphia: Temple University Press, 2002.

Copeland, Gloria. No Deposit, No Return. Fort Worth, TX: Kenneth Copeland Publications, 1995. 
_. God's Will Is Prosperity. Tulsa: Harrison House, 1978.

Copeland, Kenneth. Dear Partner. Fort Worth, TX: Kenneth Copeland Publications, 1997.

—. The Laws of Prosperity. Greensburg, PA: Mann Christian Outreach, 1974.

—. Poverty: The Choice is Yours. Fort Worth: Kenneth Copeland Publications, 1985.

Copeland, Kenneth and Gloria Copeland. Prosperity Promises. Tulsa: Kenneth Copeland Ministries, 1997.

Dollar, Creflo. The Color of Love: Understanding God's Answer to Racism, Separation, and Division. Tulsa: Harrison House, 1997.

—. How to Obtain Healing...the Final Authority. College Park, Georgia: Creflo Dollar Ministries, 1999.

—. Jehovah M'Kaddesh. Atlanta: Creflo Dollar Ministries, 2001.

—_. Jehovah Nissi. Atlanta: Creflo Dollar Ministries, 2000.

—_. Jehovah Rophe. Atlanta: Creflo Dollar Ministries, 2000.

—_. Jehovah Shammah. Atlanta: Creflo Dollar Ministries, 2000.

—_. Jehovah Tsidkenu. Atlanta: Creflo Dollar Ministries, 2000.

—_. Total Life Prosperity: 14 Practical Steps to Receiving God's Full Blessing. Nashville: Thomas Nelson Publishers, 1999.

Dowland, Seth. Family Values: Gender, Authority, and the Rise of the Christian Right. Philadelphia: University of Pennsylvania Press, 2012.

du Plessis, David. Simple and Profound. New Orleans: Paraclete Press, 1986.

Fillmore, Charles. Christian Healing: The Science of Being. Unity Village, MO: Unity School of Christianity, 1950.

Hagee, John. Attack on America. Nashville: Thomas Nelson, 2001.

—. The Battle for Jerusalem. Nashville: Thomas Nelson, 2003.

—. Financial Armageddon: We are in a Battle for our Very Survival. Lake Mary, FL.: FrontLine, 2008.

—. From Daniel to Doomsday. Nashville: Thomas Nelson, 2000.

—. In Defense of Israel. Lake Mary, FL.: FrontLine, 2007.

—. Jerusalem Countdown. Lake Mary, FL.: FrontLine, 2006. 
Hagin, Kenneth. The Biblical Keys to Financial Prosperity. Tulsa: Kenneth Hagin Ministries, 2005.

—_. El Shaddai: The God Who is More Than Enough. Tulsa: Kenneth Hagin Ministries, 1987.

—_. In Him. Tulsa: Kenneth Hagin Ministries, 2006.

—. The Midas Touch. Tulsa: Kenneth Hagin Ministries, 2000

—. The Name of Jesus. Tulsa: Kenneth Hagin Ministries, 1979.

—. Obedience in Finances. Tulsa: Kenneth Hagin Ministries, 1983.

—. The Precious Blood of Jesus. Tulsa: Kenneth Hagin Ministries, 1984.

—. The Woman Question. Tulsa: Faith Library Publications, 1983.

— What To Do When Faith Seems Weak \& Victory Lost. Tulsa: Kenneth Hagin Ministries, 1979.

Hanby, Mark David. “Look What the Lord has Done.” Exaltation Music, 1974.

Hickey, Marilyn. Speak the Word. Tulsa: Harrison House, 1983.

__. Your Miracle Source. Tulsa: Harrison House, 1982.

Hilliard, My Strong Tower: Power in Knowing the Names of God. Houston: Hilliard Ministries, 2009.

Hillsong United, “Shout Unto God,” Hillsong Music Australia, 2008.

Hood, Kregg. Take God at His Word: Expect a Harvest. Hurst, TX: Sweet Publishing, 2001.

Hunter, Frances. A Confession A Day Keeps the Devil Away. Kingwood, TX: Hunter Books, 1980.

—. God's Answer to Fat: Loose It. Houston: Hunter Ministries, 1976.

Jakes, Jacqueline and T.D. Jakes. God's Trophy Women: You are Blessed and Highly Favored. New York: FaithWords, 2006.

Jakes, T.D. Lay Aside the Weight: Taking Control of the Weight Before It Takes Control of You. Tulsa: Albury Publications, 1997.

—. Reposition Yourself: Living Life Without Limits. New York: Atria Books, 2008.

Jaggers, O. L. Everlasting Physical and Spiritual Health. Dexter, MO: Kessinger Publishing, 1949.

Jones, Laurie Beth. Jesus Inc.: The Visionary Path. Promotional book insert, The Crown Public Group, 2001. 
Jones, Noel and Scott Chaplan. Vow of Prosperity: Spiritual Solutions for Financial Freedom. Shippensburg, Penn.: Destiny Image, 2007.

Kenyon, E. W. The Father and His Family: A Restatement of the Plan of Redemption (Lynnwood, WA: Kenyon's Gospel Publishing Society, 1998.

— New Creation Realities. Lynnwood, WA: Kenyon's Gospel Publishing Society, 1970.

- The Two Kinds of Faith: Faith's Secret Revealed. Lynnwood, WA: Kenyon's Gospel Publishing Society, 1998.

—. The Two Kinds of Life. Lynnwood, WA: Kenyon's Gospel Publishing Society, 1983.

— Society, 1998),

- Advanced Bible Course: Studies in the Deeper Life, $5^{\text {th }}$ ed. (Lynnwood, WA: Kenyon's Gospel Publishing Society, 1970)

Lake, John G. The John G. Lake Sermons on Dominion over Demons, Disease, and Death. Dallas: Christ for the Nations, 1982.

Law, Terry. "The Power of Praise and Worship." In Principles of Praise. Tulsa: Victory House, 1985.

Lindsay, Gordon. Bible Days Are Here Again: Divine Healing for Today and God's Plan for Ending Sickness. Shreveport, LA: G. Lindsay, 1949.

- God's Master Key to Success and Prosperity. Dallas: The Voice of Healing Publishing Company, 1959.

Meyer, Joyce. Eat $\mathcal{E}$ Stay Thin: Simple, Spiritual, Satisfying Weight Control. Tulsa: Harrison House, 1999.

Miller, Basil. Grappling With Destiny. Los Angeles: Wings of Healing, 1962.

Munroe, Miles. Kingdom Principles: Preparing the Kingdom Experience and Expansion. Shippensburg, PA: Destiny Image Publishers, 2006.

Munizzi, Martha. "Say The Name." Sony Recordings. 2002.

Murray, Andrew. Divine Healing. 1884.

Osborn, T. L. Healing the Sick. Oklahoma City: T. L. Osborn Evangelistic Association, 1992.

—_. One Hundred Divine Healing Facts. Tulsa: Harrison House, 1983. 
Osteen, Joel. Become a Better You: 7 Keys to Improving Your Life Every Day. New York: Free Press, 2007.

- Healthy Living: Discover God's Plan for a Stronger, Happier, Younger Looking You! Houston: Joel Osteen Ministries, 2006.

—. Your Best Life Now: 7 Steps to Living at Your Full Potential (New York: Faithwords, 2004).

Osteen, John. What To Do When Nothing Seems to Work. Houston: Lakewood Church, 1981.

—. There Is a Miracle in Your Mouth. Houston: John Osteen Ministries, 1972.

—. This Awakening Generation. Houston: John Osteen Ministries, 1964.

- Unraveling the Mystery of the Blood Covenant (Houston: John Osteen Publications, 1987.

Parsley, Rod. Daily Breakthrough: Daily Devotions to Take You Into God's Promise. Orlando: Charisma House, 1998.

Peale, Norman Vincent. The Power of Positive Thinking. New York: Prentice Hall Press, 1987

Prince, Derek. Blessings and Curses. Grand Rapids: Chosen Books, 2003.

Price, Frederick. Azusa Street Centennial General Sessions (CD), Divide, CO: Kingdom Recordings, 2006.

—. Is Healing for All? Tulsa: Harrison House, 1976.

—. Race, Religion \& Racism. Los Angeles, CA: Faith One Publications, 1999.

—. The Truth About Disasters. Los Angeles: Faith One Publishing, 1999.

- They Shall Expel Demons: What You Need to Know about Demons-Your Invisible Enemies. Washington Depot, CT: Chosen Books, 1998.

Roberts, Oral. Oral Roberts' Life Story: As Told by Himself. Tulsa, Okla: Oral Roberts Ministry, 1952.

—. How I Learned Jesus Was Not Poor. Altamonte Springs, FL: Creation House, 1989.

Robertson, Pat and Bob Drosser. The Secret Kingdom. Nashville: Thomas Nelson, 1982.

Robison, James. True Prosperity: Truth Matters. Carol Stream, Illin.: Tyndale House: 2004.

Schuller, Robert. Possibility Thinking. Chicago, IllL: Nightingale-Conant Corp, 1981. 
—. Your Church Has Real Possibilities! Glendale, CA: Regal Books, 1974.

Sesley, Kenneth R. Firstfruits: God's Plan to Propel You from Poverty to Prosperity! Longwood, FL.: Xulon Press, 2009.

Stewart, Don. Only Believe: An Eyewitness Account of the Great Healing Revivals of the $20^{\text {th }}$ Century. Shippensburg, PA: Revival Press, 1999.

Swaggart, Jimmy. The Confession Principle and the Course of Nature. Baton Rouge, LA: Jimmy Swaggart Ministries, 1981.

Swaggart, Jimmy and Marvin E. Solum. The Balanced Faith Life. Baton Rouge, LA: Jimmy Swaggart Ministries, 1981.

Thompson, Leroy. Money Cometh to the Body of Christ. Tulsa: Harrison House, 1999.

Wangenye, Stan. God's Will Still Is Prosperity! Longwood, FL.: Xulon Press, 2009.

Wigglesworth, Smith. Smith Wigglesworth on Healing. New Kensington, U.K: Whitaker House, 1999.

Williams, Dave. The Miracle Results of Fasting: Discover the Amazing Benefits in Your Spirit, Soul, and Body. Tulsa: Harrison House, 2004.

Wilkinson, Bruce. The Dream Giver: Following Your God-Given Destiny. Portland, OR.: Multnomah, 2003.

- The Prayer of Jabez: Breaking Through to the Blessed Life. Portland, OR.: Multnomah, 2000.

Winch, Terry. “Jehovah Jireh,” EMI Christian Music Publishing, 1978.

White, Paula. Birthing Your Dreams: God's Plan for Living Victoriously. New York: Thomas Nelson, 2003.

- Ten Commandments for Health and Wellness. Tampa: Paula White Enterprises, 2007.

Yeomans, Lilian. His Healing Power. Tulsa: Harrison House, 2003.

\section{Secondary Sources}

Ahlstrom, Sydney E. A Religious History of the American People. New Haven: Yale University Press, 1972.

Albanese, Catherine. A Republic of Mind and Spirit: A Cultural History of American Metaphysical Religion. New Haven: Yale University Press, 2007. 
—. America: Religion and Religions. Belmont, CA: Wadsworth, 1992.

Albert, James A. Jim Bakker: Miscarriage of Justice? Chicago: Carus Publishing, 1998.

Allitt, Patrick. Religion in America Since 1945. New York: Columbia University Press, 2003.

Anker, Roy. Self-Help and Popular Religion in Modern American Culture: An Interpretive Guide. Westport, CT: Greenwood Press, 1999.

Archer, Kenneth. A Pentecostal Hermeneutic for the Twenty-First Century: Spirit, Scripture and Community. London; New York: T \& T Clark, 2004.

Baer, Hans A. "Elder Solomon Michaux's Church of God." In Encyclopedia of African and African-American Religions. New York: Routledge, 2001.

—. The Black Spiritual Movement: A Religious Response to Racism. Knoxville: University of Tennessee Press, 1984.

Baer, Hans A. and Merrill Singer. African-American Religion in the 20th Century: Varieties of Protest and Accommodation. Knoxville: University of Tennessee Press, 1992.

Balmer, Randall H. "Benny Hinn." In The Encyclopedia of Evangelicalism. Waco, TX: Baylor University Press, 2004.

Barron, Bruce. The Health and Wealth Gospel. Downers Grove: InterVarsity Press, 1987.

Best, Wallace. Passionately Human, No Less Divine: Religion and Culture in Black Chicago, 1915-1952. Princeton: Princeton University Press, 2005.

Billingsley, Scott. It's a New Day: Race And Gender in the Modern Charismatic Movement. Tuscaloosa: University of Alabama Press, 2008.

Blumhofer, Edith. Restoring the Faith: The Assemblies of God, Pentecostalism, and American Culture. Urbana: University of Illinois Press, 1993.

Bowler, Catherine. "Positive Thinking." In The Encyclopedia of Religion in America Washington: CQ Press, forthcoming 2010.

Boyer Sagert, Kelly. The 1970s. Westport, Connecticut: Greenwood Press, 2007.

Braden, Charles Samuel, Spirits in Rebellion: The Rise and Development of New Thought. Dallas, Southern Methodist University Press, 1963.

Braude, Ann. Radical Spirits: Spiritualism and Women's Rights in Nineteenth-Century America. 2nd ed. Bloomington: Indiana University Press, 2001. 
Brown, Michael F. The Channeling Zone: American Spirituality in an Anxious Age. Cambridge, MA: Harvard University Press, 1997.

Budde, Michael and Robert Brimlow. Christianity Incorporated: How Big Business is Buying the Church. Grand Rapids, MI.: Brazos Press, 2002.

Burpeau, Kemp Pendleton. God's Showman: A Historical Study of John G. Lake and South African/American Pentecostalism. Oslo: Refleks Publishing, 2004.

Butler, Jon. Awash in a Sea of Faith: Christianizing the American People. Cambridge, Mass: Harvard University Press, 1990.

Byrd, W. Michael. and Linda A. Clayton. An American Health Dilemma. New York: Routledge, 2000-2002.

Carlton, Brittany S. "Mental Illness in the African American Community." Seminar paper, University of Indiana, 2009.

Carter, Harold A. Prayer Tradition of Black People. Valley Forge, Pa: Judson, 1976.

Carter, Paul Allen. The Spiritual Crisis of the Gilded Age. DeKalb: Northern Illinois University Press, 1971.

Cerulo, Karen. Never Saw It Coming: Cultural Challenges to Envisioning the Worst. Chicago: Chicago University Press, 2006.

Chaves, Mark. Congregations in America. Cambridge, MA.: Harvard University Press, 2004.

Cherry, Conrad. God's New Israel: Religious Interpretations of American Destiny. Chapel Hill: University of North Carolina Press, 1998.

Chireau, Yvonne. Black Magic: Religion and the African American Conjuring Tradition. Berkeley: University of California Press, 2003.

Conwell, Conrad. Acres of Diamonds. Philadelphia: Temple University Press, 2002.

Coontz, Stephanie. Marriage, a History: How Love Conquered Marriage. New York: Penguin Books, 2005.

Curtis, Heather. Faith in the Great Physician: Suffering and Divine Health in American Culture, 1860-1900. Baltimore: The Johns Hopkins University Press, 2007.

Dallam, Marie W. Daddy Grace: A Celebrity Preacher and His House Of Prayer. New York: NYU Press, 2007.

Dayton, Donald W. Theological Roots of Pentecostalism. Metuchen, NJ: Scarecrow Press, 1987. 
Ehrenreich, Barbara. Bright-Sided: How the Relentless Promotion of Positive Thinking Has Undermined America. New York: Metropolitan Books, 2009.

Elson, Ruth Miller. Myths and Mores in American Best Sellers, 1865-1965. New York: Garland, 1985.

Emerson, Michael O. and Christian Smith. Divided by Faith: Evangelical Religion and the Problem of Race in America. New York: Oxford University Press, 2001.

Fauset, Arthur Huff. Black Gods of the Metropolis: Negro Religious Cults of the Urban South. Philadelphia: University of Pennsylvania Press, 1941.

Finstuen, Andrew S. Original Sin and Everyday Protestants: The Theology of Reinhold Niebuhr, Billy Graham, and Paul Tillich in an Age of Anxiety. Chapel Hill, NC.: University of North Carolina Press, 2009.

Frankiel, Tamar. "Ritual Sites in the Narrative of American Religion," in American Spiritualities edited by Catherine Albanese. Bloomington, IN: University of Indiana Press, 2001.

Giuliano, Michael James. Thrice-Born: The Rhetorical Comeback of Jimmy Swaggart Macon, GA: Mercer University Press, 1999.

Göransson, Kristina. The Binding Tie: Chinese Intergenerational Relations in Modern Singapore. Honolulu: University of Hawaii Press, 2009.

Griffith, R. Marie. Born Again Bodies: Flesh and Spirit in American Christianity. Berkeley: University of California Press, 2004.

- God's Daughters: Evangelical Women and the Power of Submission. Berkeley: University of California Press, 1997.

Gunther Brown, Candy. Global Pentecostalism. New York: Oxford University Press, 2010.

Gutiérrez, Ramon. When Jesus Came, the Corn Mothers Went Away. Stanford, CA.: Stanford University Press, 1991.

Hadden, Jeffrey K. "Religious Broadcasting," The New Encyclopedia of Southern Culture, vol. one (Chapel Hill, NC: University of North Carolina Press, 2006.

Hall, David D. Worlds Of Wonder, Days Of Judgement: Popular Religious Belief in Early New England. New York: Alfred A Knopf, 1990.

Hammond, Frank and Ida Mae Hammand. Pigs in the Parlor: The Practical Guide to Deliverance. Kirkwood, MO: Impact Books, 1973.

Hanegraaff, Hank. Christianity in Crisis. Eugene: Harvest House, 1993. 
Hardesty, Nancy. Faith Cure: Divine Healing in the Holiness and Pentecostal Movements

(Peabody, MA: Hendrickson Publishers, 2003.

Harley, Gail. Emma Curtis Hopkins: Forgotten Founder of New Thought. Syracuse:

Syracuse University Press, 2002.

Harrell, David Edwin. All Things Are Possible: The Healing and Charismatic Revivals in Modern America. Bloomington: Indiana University Press, 1975.

Pat Robertson: A Personal, Religious, and Political Portrait. San Francisco: Harper \& Row, 1988.

_. Oral Roberts: An American Life. Bloomington: Indiana University Press, 1985.

Harrison, Milmon. Righteous Riches: The Word of Faith Movement in Contemporary African American Culture. New York: Oxford University Press, 2005.

Harley, Gail M. Emma Curtis Hopkins: Forgotten Founder of New Thought. Syracuse, NY: Syracuse University Press, 2002.

Harvey, Paul. "Black Protestantism: A Historiographical Appraisal," in American Denominational History: Perspectives on the Past, Prospects for the Future, ed. Keith Harper, 120-146. Tuscaloosa: University of Alabama Press, 2008.

Herskovits, David. The Myth of the Negro Path. New York: Harper \& Bros., 1941.

Hinson, Glen. "Stepping Around Experience and the Supernatural." In Fire in My Bones: Transcendence and the Holy Spirit in African American Gospel. Philadelphia: University of Pennsylvania Press, 2000.

Holifield, Brooks. God's Ambassadors: A History of the Christian Clergy in America. Grand Rapids: Eerdmans, 2007.

Horsfield, Peter G. Religious Television: The American Experience. New York: Longman Inc., 1984.

Hudnut-Beumler, James David. In Pursuit of the Almighty's Dollar: A History of Money and American Protestantism. Chapel Hill, NC: University of North Carolina Press, 2007.

Hudson, Deal Wyatt. Onward Christian soldiers: the growing political power of Catholics and evangelicals in the United States. New York, NY: Threshold Editions, 2008.

Hutchison, William R. Religious Pluralism in America: The Contentious History of a Founding Ideal. New Haven, CT: Yale University Press, 2003.

Jacobsen, Douglas Gordon. Thinking in the Spirit: Theologies of the Early Pentecostal Movement. Bloomington, IN: Indiana University Press, 2003. 
James, William. The Varieties of Religious Experience: A Study in Human Nature. Cambridge, MA.: Harvard University Press, 1985.

Jenkins, Philip. The Next Christendom: The Coming of Global Christianity. New York: Oxford University Press, 2002.

------. Mystics and Messiahs: Cults and New Religions in American History (New York: Oxford University Press, 2000.

Johns, Jackie David. "Pentecostalism." In The Encyclopedia of Christianity. Grand Rapids, MI.: Brill, 1999-2008.

King, Paul L. Only Believe: Examining the Origin and Development of Classic and Contemporary "Word of Faith" Theologies. Tulsa: Word \& Spirit Press, 2009.

Koester, Nancy. Fortress Introduction to the History of Christianity in the United States. Minneapolis: Fortress Press, 2007.

Lassiter, Luke. The Chicago Guide to Collaborative Ethnography. Chicago: University of Chicago Press, 2005.

Lee, Shane, and Phillip Luke Sinitiere. Holy Mavericks: Evangelical Innovators and the Spiritual Marketplace. New York: New York University Press, 2009.

Lie, Geir. E. W. Kenyon, Cult Founder or Evangelical Minister? Oslo: Refleks Publishing, 2003.

Lindner, Eileen. Yearbook of American and Canadian Churches. New York: NCC Communication Department, 2006.

Lippy, Charles H. Modern American Popular Religion: A Critical Assessment and Annotated Bibliography. Westport, CT: Greenwood Press, 1996.

Long, Carolyn. Spiritual Merchants: Religion, Magic, and Commerce. Knoxville: University of Tennessee Press, 2001.

Loveland, Anne C., and Otis B. Wheeler, From Meetinghouse to Megachurch: A Material and Cultural History. Columbia: University of Missouri Press, 2003.

MacRobert, Iain. “The Black Roots of Pentecostalism." In African-American Religion, 295309. New York: Routledge, 1997.

Manon Bourgault, Louise. An Ethnographic Study of the "Praise the Lord Club." Ph.D. dissertation, Ohio State University, 1980.

Martin, Darnese C. Beyond Christianity: African Americans in a New Thought Church. [S.1.]: New York University Press, 2005. 
McConnell, D. R., A Different Gospel. Peabody, MA: Hendrickson Publishers, 1988.

McIntyre, Joe. E. W. Kenyon and His Message of Faith: The True Story. Lake Mary, FL: Creation House, 1997.

McGavran, Donald. Understanding Church Growth. Grand Rapids: Eerdmans, 1990.

Mearsheimer, John, J. The Israel Lobby and U.S. Foreign Policy. New York: Farrar, Straus and Giroux, 2007.

Melton, Gordon. "Rex Humbard." In Religious Leaders of America: A Biographical Guide to Founders and Leaders of Religious Bodies, Churches, and Spiritual Groups in North America. Detroit, MI: Gale Research, 1999.

Meyer, Donald B. The Positive Thinkers: Popular Religious Psychology from Mary Baker Eddy to Norman Vincent Peale and Ronald Reagan. Middletown, Conn: Wesleyan University Press, 1988.

Miller, Donald E. and Tetsuano Yamamori. Global Pentecostalism: The New Face of Christian Social Engagement. Berkeley and Los Angeles: University of California Press, 2007.

Miller, Glenn. Piety and Profession: American Protestant Theological Education, 1870-1970. Grand Rapids, MI.: William B. Eerdmans Pub., 2007.

Mitchem, Stephanie Y. Name It and Claim It? Prosperity Preaching in the Black Church. Cleveland: Pilgrim Press, 2007.

Moore, R. Laurence. Religious Outsiders and the Making of Americans. New York: Oxford University Press, 1986.

Morgan, Edmund. The Puritan Dilemma. New York: Longman, 1999.

Moses, Wilson Jeremiah. "Chosen Peoples of the Metropolis: Black Muslims, Black Jews, and Others." In African American Religious Thought, ed. Cornel West and Eddie S. Glaude, 534-549. Louisville: Westminster John Knox Press, 2003.

Pinn, Anthony. The African American Religious Experience in America. Westport: Greenwood Publishing Group, 2006.

Porterfield, Amanda. Healing in the History of Christianity. New York: Oxford University Press, 2005.

Priest, Robert, and Alvaro L. Nieves. This Side of Heaven: Race, Ethnicity, and Christian Faith. New York: Oxford University Press, 2007.

Raboteau, Albert. Slave Religion. New York: Oxford University Press, 1978.

Randi, James. The Faith Healers. Buffalo, NY: Prometheus Books, 1987. 
Rudolph, Frederick. The American College and University, A History. New York: Knopf, 1962.

Sanneh, Lamin. Whose Religion is Christianity? The Gospel Beyond the West. Grand Rapids, MI: Eerdmans, 1993.

Satter, Beryl. "Marcus Garvey, Father Divine, and the Gender Politics of Race Difference and Race Neutrality." In African American Religious Thought, ed. Jr.,Cornel West and Eddie S. Glaude. Louisville: Westminster John Knox Press, 2003.

- Each Mind A Kingdom: American Women, Sexual Purity, and the New Thought Movement, 1875-1920. Berkeley: University of California Press, 1999.

Schulman, Bruce J. The Seventies: The Great Shift in American Culture, Society, and Politics. New York: The Free Press, 2001.

Simmons, Dale. E. W. Kenyon and the Postbellum Pursuit of Peace, Power, and Plenty. London: Scarecrow Press, 1997.

Smith, Christian and Michael O. Emerson, Divided by Faith: Evangelical Religion and the Problem of Race in America. New York: Oxford University Press, 2001.

Susanto, Johanes Lilik. “A Practical Theological Evaluation of the Divine Healing Ministries of Smith Wigglesworth and John G. Lake: A Continuationist Reformed Perspective," Doctor of Theology Thesis, University of South Africa, Pretoria, South Africa, June 2007.

Synan, Vinson. The Century of the Holy Spirit: 100 Years of Pentecostal and Charismatic Renewal, 1901-2001. Nashville: Thomas Nelson Publishers, 2001.

. The Holiness-Pentecostal tradition: Charismatic movements in the twentieth century. Grand Rapids, Mich. : W.B. Eerdmans Pub. Co., 1997.

Taves, Ann. Fits, Trances, $\mathcal{E}$ Visions: Experiencing Religion and Explaining Experience from Wesley to James. Princeton, N.J.: Princeton University Press, 1999.

Thumma, Scott, and Dave Travis. Beyond Megachurch Myths: What We Can Learn From America's Largest Churches. 1st ed. San Francisco, CA: Jossey-Bass, 2007.

Trachtenberg, Alan, and Eric Foner. The Incorporation of America: Culture and Society in the Gilded Age. New York: Hill and Wang, 1982.

Wacker, Grant. Heaven Below: Early Pentecostals and American Culture. Cambridge, MA.: Harvard University Press, 2001.

. "The Pentecostal Tradition," in Caring and Curing: Health and Medicine in the Western Religious Traditions edited by Ronald L. Numbers and Darrel W. Amundsen. New York: Macmillan Publishing Company, 1986. 
Walsh, Arlene Sanchez. "Santidad, Sanacion, Salvacion, Liberacion: The Word of Faith Movement among Twenty-first Century Latin@ Pentecostal," In Global Pentecostal and Charismatic Healing. New York: Oxford University Press, 2010.

Walton, Jonathan. Watch This!: The Ethics And Aesthetics of Black Televangelism. New York City: New York University Press, 2009.

Ward, W. R. Early Evangelicalism: A Global Intellectual History, 1670-1789. Cambridge: Cambridge University Press, 2006.

Watson, Justin. The Christian Coalition: Dreams of Restoration, Demands for Recognition. New York: St. Martin's Press, 1997.

Watts, Jill. God, Harlem, U.S.A: The Father Divine Story. Berkeley: University of California Press, 1995.

Wiegele, Katharine. Investing in Miracles: El Shaddai and the Transformation of Popular Catholicism in the Philippines. Honolulu: University of Hawaii Press, 2005.

Weiss, Richard. The American Myth of Success: From Horatio Alger to Norman Vincent Peale. Urbana: University of Illinois Press, [1969] 1988.

Wellman, Jr. "The Church of the Pacific Northwest: The Rise of Sectarian Entrepreneurs," In Religion \& Public Life in the Pacific Northwest: The None Zone. Walnut Creek, CA.: AltaMira Press, 2004.

White, Shane and Graham White. Stylin': African American Expressive Culture, from Its Beginnings to the Zoot Suit. Cornell University Press, 1999.

Whorton, James C. Nature Cures: The History of Alternative Medicine in America. New York: Oxford University Press, 2004.

Williams, Joseph. “The Transformation of Pentecostal Healing: 1906-2006." Ph.D. dissertation, Florida State University, 2008.

Williams, Tammy R. "Is There a Doctor in the House? Reflections on the Practice of Healing in African American Churches." In Practicing Theology: Beliefs and Practices in Christian Life, ed. Miroslav Volf and Dorothy C. Bass. Grand Rapids: Eerdmans, 2002.

Wyllie, Irvin. The Self-Made Man in America: The Myth of Rags to Riches. New Brunswick, NJ.: Rutgers University Press, 1954. 


\section{Biography}

Catherine Bowler was born June 16, 1980, in London, England. In 2002 she graduated magna cum laude from Macalester College in St. Paul, Minnesota, with a Bachelor of Arts in Religion. Catherine earned a Master of Arts in Religion, summa cum laude, from Yale University, New Haven, in 2005. She was the recipient of the Z. Marshall Crane Scholarship Fund (2003-2005). In the spring of 2010, she completed a Ph.D. at Duke University in the Graduate Program in Religion with the generous assistance of a Duke International Travel Grant (2008), Center for Research on Canadian Evangelicalism Grant (2008), and a Center for Canadian Studies Grant (2006, 2008). Also in 2010, she accepted a position as assistant professor of religion at Duke Divinity School in Durham, North Carolina. 